\title{
Environmental Monitoring Plan United States Department of Energy Richland Operations Office
}

November 2000

Prepared by personnel from

Pacific Northwest National Laboratory,

Fluor Hanford, Inc. and its subcontractor

Waste Management Federal Services, Inc., a subsidiary of GTS Duratek, for the

U.S. Department of Energy

under Contract DE-AC06-76RL01830

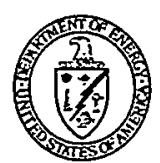

United States

Department of Energy

P.O. Box 550

Richland, Washington 99352

MECENEO

NOV 242090

OSTI

Approved for Public Release 


\section{DISCLAIMER}

This report was prepared as an account of work sponsored by an agency of the United States Government. Neither the United States Government nor any agency thereof, nor any of their employees, make any warranty, express or implied, or assumes any legal liability or responsibility for the accuracy, completeness, or usefulness of any information, apparatus, product, or process disclosed, or represents that its use would not infringe privately owned rights. Reference herein to any specific commercial product, process, or service by trade name, trademark, manufacturer, or otherwise does not necessarily constitute or imply its endorsement, recommendation, or favoring by the United States Government or any agency thereof. The views and opinions of authors expressed herein do not necessarily state or reflect those of the United States Government or any agency thereof. 


\section{DISCLAIMER}

Portions of this document may be illegible in electronic image products. Images are produced from the best available original document. 


\section{Preface}

This Hanford Site Environmental Monitoring Plan was prepared for the U.S. Department of Energy's (DOE's) Richland Operations Office (RL) and Office of River Protection (ORP) to implement the requirements of DOE Order 5400.1. According to the Order, each DOE site, facility, or activity that uses, generates, releases, or manages significant pollutants or hazardous materials shall prepare a written environmental monitoring plan covering two major activities: 1) effluent monitoring and 2) environmental surveillance. The plan is to contain information discussing the rationale and design criteria for the monitoring programs, sampling locations and schedules, quality assurance requirements, program implementation procedures, analytical procedures, and reporting requirements. The plan's purpose is to assist DOE in the management of environmental activities at the Hanford Site and to help ensure that operations on the site are conducted in an environmentally safe and sound manner.

This plan was prepared by personnel from Pacific Northwest National Laboratory, Fluor Hanford, Inc. and its subcontractor Waste Management Federal Services, Inc., a subsidiary of GTS Duratek. Document production was coordinated for DOE-RL's Operations Office, Office of Site Services by the Pacific Northwest National Laboratory's Public Safety and Resource Protection Program. Pacific Northwest National Laboratory is operated for DOE by Battelle.

Both hard-copy and electronic versions of this plan have been produced. The hard-copy version is available for review at the DOE Public Reading Room, located in the Consolidated Information Center on the campus of Washington State University at Tri-Cities in Richland, Washington. The electronic version is available on the internet at $\mathrm{http} / / / \mathrm{www}$.hanford.gov/docs/rl-91-50. This plan was written to meet the needs of DOE and its contractors; its content, wording, and format are appropriate to those needs. Questions or concerns about this plan should be directed to Mr. D. C. (Dana) Ward, DOE-RI Operations Office, Office of Site Services, P.O. Box 550, Richland, Washington 99352 (dana_c_ward@rl.gov). 


\section{Acronyms/Initialisms}

Each section in this report is considered to be independent from each other with respect to the use of acronyms/initialisms. Any acronym/initialism used in a table or on a figure is provided thereon. For the convenience of the reader, below is a list of all the acronyms/initialisms used in the entire report.

\begin{tabular}{|c|c|}
\hline APGEMS & Air Pollutant Graphical Environmental Modeling System \\
\hline ALARA & as low as reasonably achievable \\
\hline ANSI & American National Standards Institute \\
\hline APHA & American Public Health Association \\
\hline ASME & American Society of Mechanical Engineers \\
\hline ASTM & American Society for Testing and Materials \\
\hline BHI & Bechtel Hanford, Inc. \\
\hline \multirow[t]{2}{*}{ CERCLA } & Comprehensive Environmental Response, Compensation, and Liability \\
\hline & Act of 1980 \\
\hline CFR & Code of Federal Regulations \\
\hline CHG & CH2M HILL Hanford Group, Inc. \\
\hline CPP & CERCLA past-practice \\
\hline CVAF & cold vapor atomic fluorescence \\
\hline DOE & U.S. Department of Energy \\
\hline DOE-RL & U.S. Department of Energy, Richland Operations Office \\
\hline Ecology & Washington State Department of Ecology \\
\hline $\mathrm{EDE}$ & effective dose equivalent \\
\hline EML & Environmental Measurements Laboratory \\
\hline EPA & U.S. Environmental Protection Agency \\
\hline ETF & 200 Areas Effluent Treatment Facility \\
\hline FH & Fluor Hanford, Inc. \\
\hline $\mathrm{Ge}(\mathrm{Li})$ & lithium-ion drifted germanium (detector) \\
\hline GFAA & graphic furnace atomic absorption \\
\hline HEHF & Hanford Environmental Health Foundation \\
\hline HEIS & Hanford Environmental Information System \\
\hline HPGE & hyperpure germanium (detector) \\
\hline HQ & Headquarters (DOE) \\
\hline ICP/MS & inductively coupled plasma/mass spectrometry \\
\hline
\end{tabular}


LEMIS

LEPD

LERF

LIBG

LWDF

NEPA

NPDES

NRDWL

ORP

PNNL

PUREX

QA

QC

RCRA

REDOX

RL

ROD

RPP

SARA

SST

TEDF

TLD

Tri-Party Agreement

TRUPACT-II

TSD

$\mathrm{UO}_{3}$

WAC

WESF

WMA

WRAP

WSCF
Liquid Effluent Monitoring Information System

low-energy photon detector

liquid effluent retention facility

low-level burial ground

liquid waste disposal facility

National Environmental Policy Act

National Pollutant Discharge Elimination System

Nonradioactive Dangerous Waste Landfill

DOE Office of River Protection

Pacific Northwest National Laboratory

Plutonium-Uranium Extraction Plant

quality assurance

quality control

Resource Conservation and Recovery Act of 1976

Reduction-Oxidation Plant

DOE Richland Operations Office

record of decision

RCRA past-practice

Superfund Amendments and Reauthorization Act of 1986

single-shell tank

Treated Effluent Disposal Facility

thermoluminescent dosimeter

Shortened form for the Hanford Federal Facility Agreement and Consent

Order Between the U.S. Environmental Protection Agency, the

U.S. Department of Energy, and the State of Washington Department

of Ecology, 1998

transuranic package transporter

treatment, storage, or disposal (unit)

Uranium-Trioxide Plant

Washington Administrative Code

Waste Encapsulation and Storage Facility

waste management area

Waste Receiving and Processing Facility

Waste Sampling and Characterization Facility 


\section{Contents}

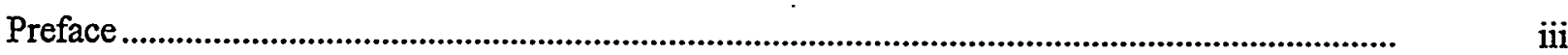

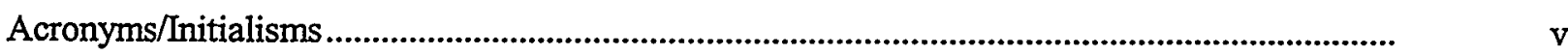

\section{Section I. Introduction}

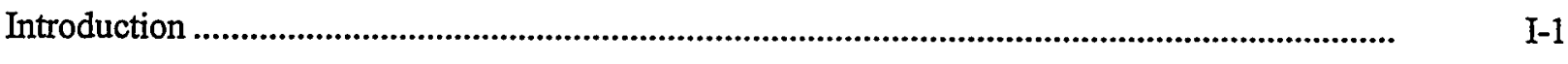

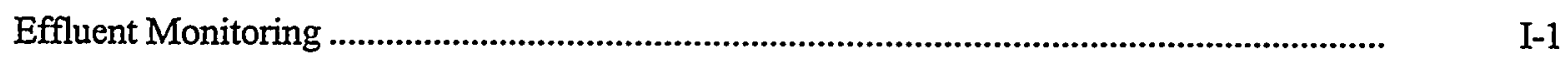

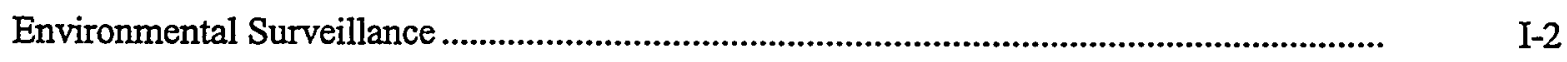

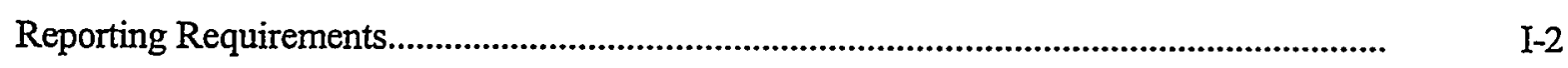

Independent Data Verification and Oversight Activities.............................................. I-3

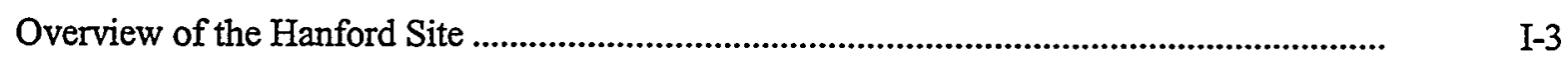

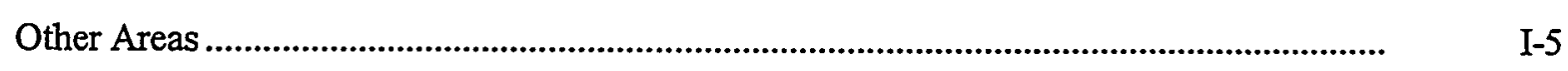

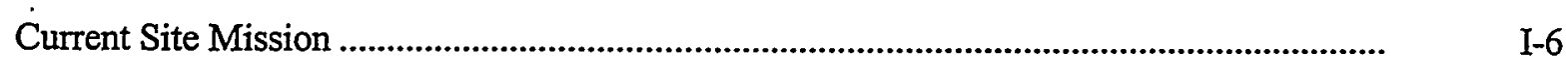

Operations/Conditions Change Notification ............................................................ I-7

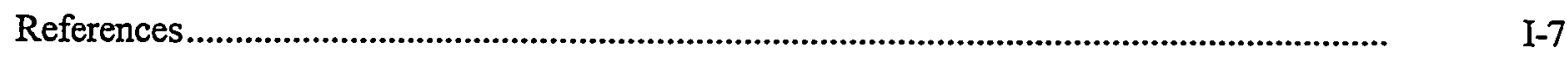

\section{Section II.A. Facility Effluent Monitoring Plans}

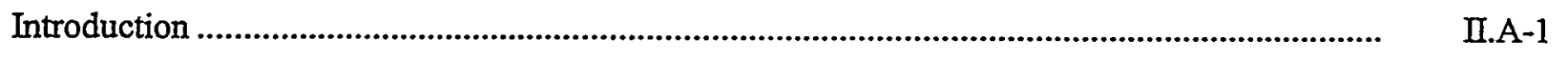

Determination of Need for a Facility Effluent Monitoring Plan .............................................. II.A-1

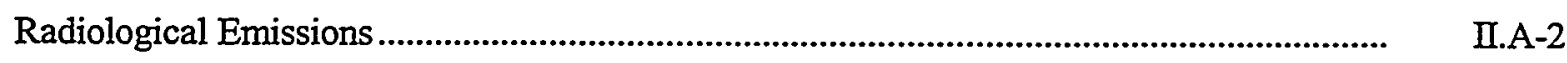

Nonradiological Emissions.................................................................................... II.A-2

Facility Effluent Monitoring Plan Preparation...................................................................... II.A-3

Environmental ALARA Program ................................................................................ II.A-8

Potential Unmitigated Doses from Hanford Facilities ...................................................... II.A-8

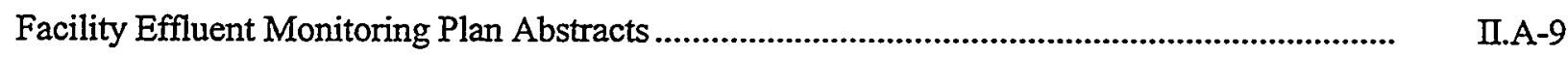




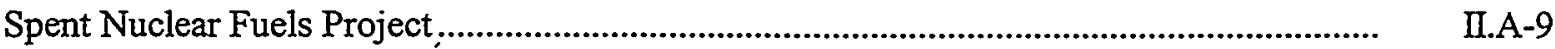

KE and KW Fuel Storage Basins................................................................................. II.A

Cold Vacuum Drying Facility................................................................................ II.A-10

Canister Storage Building ..................................................................................... II.A-10

Airborne Effluents .................................................................................................. II.A-10

Liquid Effluents..................................................................................................... II.A-10

Facility Effluent Monitoring Plan Determination ....................................................... II.A-10

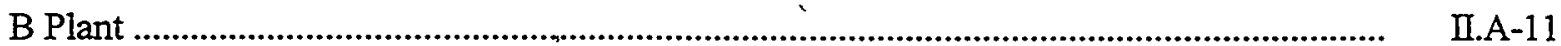

Airborne Effluents ................................................................................................ II.A-11

Liquid Effluents..................................................................................................... II.A-11

Facility Effluent Monitoring Plan Determination .............................................. II.A-11

Waste Encapsulation and Storage Facility .................................................................... II

Airborne Effluents ...................................................................................... II.A -11

Liquid Effluents.............................................................................................. II.A -11

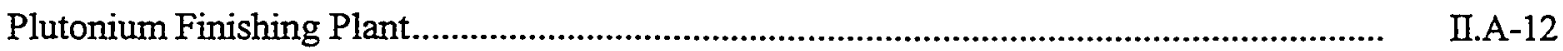

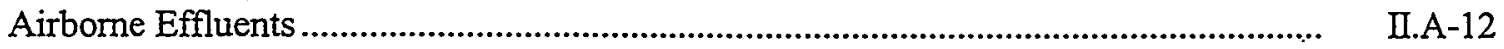

Liquid Effluents............................................................................................ II.A-12

Facility Effluent Monitoring Plan Determination .......................................................... II.A-12

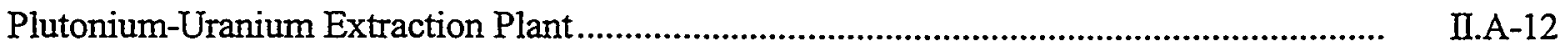

Airborne Effluents ................................................................................................ II.A-12

Liquid Effluents................................................................................................. II.A-12

Facility Effluent Monitoring Plan Determination ..................................................... II.A-13

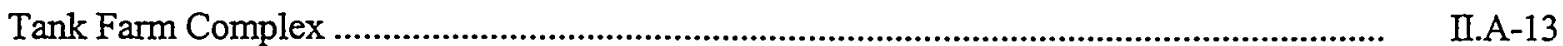

Airborne Effluents ........................................................................................... II.A-13

Liquid Effiuents................................................................................................. I.A-13

Facility Effluent Monitoring Plan Determination .................................................. II.A-13

Waste Receiving and Processing Facility ............................................................... II.A-13

Airborne Effluents ............................................................................................ I.A 14

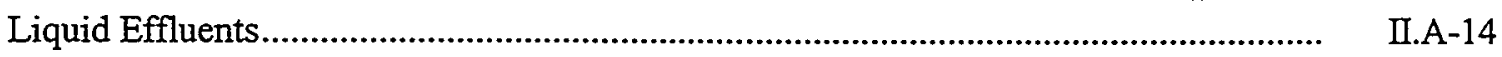

Facility Effluent Monitoring Plan Determination ..................................................... I I.A -14

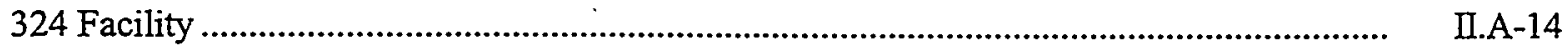

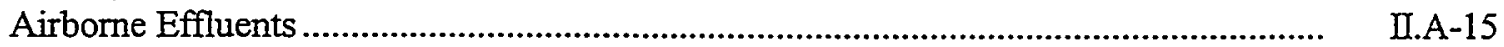

Liquid Effluents..................................................................................................... II.A-15

Facility Effluent Monitoring Plan Determination ................................................. II.A-15

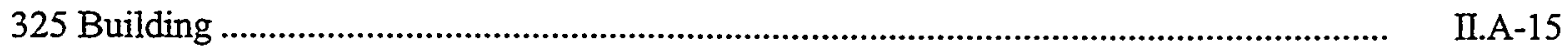

Airborne Effluents .............................................................................................. II.A-16

Liquid Effluents...................................................................................... II.A-16

Facility Effluent Monitoring Plan Determination ................................................... II.A-16

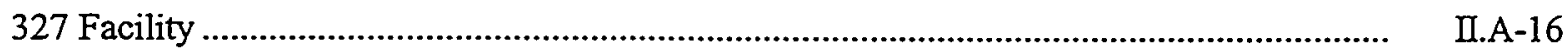

Airborne Effluents ..................................................................................... II.A -17

Liquid Effluents......................................................................................... II.A-17

Facility Effluent Monitoring Plan Determination ................................................ II.A-17 


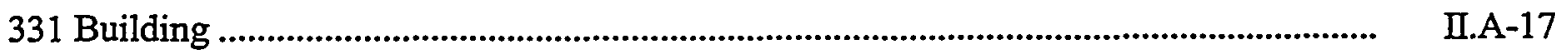

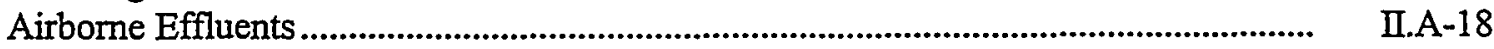

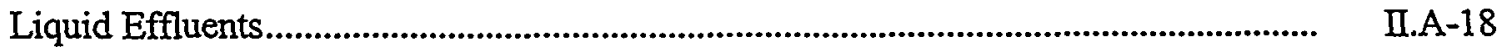

Facility Effluent Monitoring Plan Determination ............................................................... II.A-18

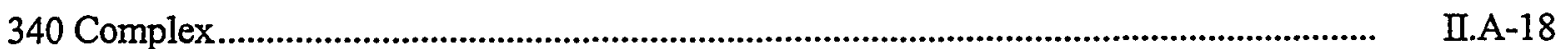

Airborne Effluents ............................................................................................... I-18

Liquid Effluents................................................................................................... II.A-19

Facility Effluent Monitoring Plan Determination ..................................................... II.A-19

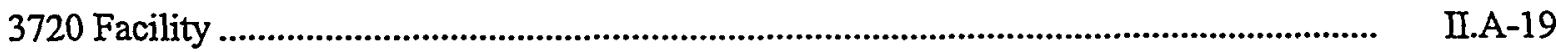

Airborne Effluents ................................................................................................ II.A-19

Liquid Effluents................................................................................................... II.A-19

Facility Effluent Monitoring Plan Determination ....................................................... II.A-20

Pacific Northwest National Laboratory Balance-of-Point ................................................... II.A-20

Airborne Effluents .................................................................................................. I.

Liquid Effluents................................................................................................. II.A-21

Facility Effluent Monitoring Plan Determination ........................................................ II.A-21

References

Section II.B. Near-Facility Environmental Monitoring

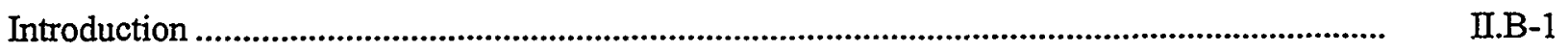

Preoperational Environmental Survey ..................................................................................... II.B-1

User Identification............................................................................................... II

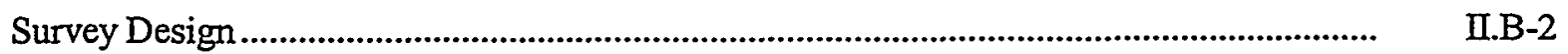

Routine Near-Facility Environmental Monitoring ............................................................... II.B-2

User Identification.................................................................................................... I.

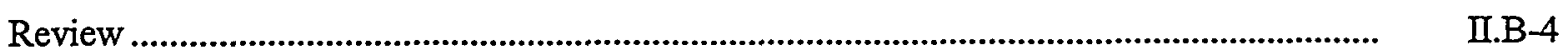

Design ........................................................................................................................ II.B-4

Sampling Locations, Frequency, Media Sampled, and Parameters Monitored................ I I.B-4

Monitoring Locations ............................................................................................. II.B-6

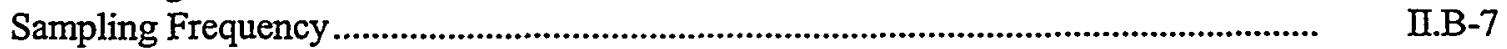

Sampling and Measurement Methods....................................................................... I I.B-7

Parameters Monitored............................................................................................. I I.B-9

Quality Assurance and Quality Control ............................................................................ II.B

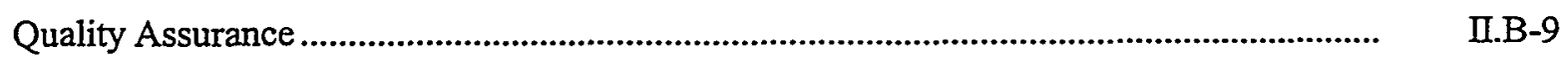

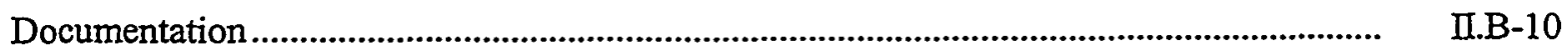


Sample Replication

Data Analysis

Analytical Procedures

References.

\section{Section III.A. Surface Environmental Surveillance}

Introduction

Requirements and Objectives of Environmental Surveillance

Rationale and Design Criteria

III.A-3

Media Selection

Sampling Locations

III.A-5

Sampling and Analysis Frequencies....

III.A-5

Detection and Precision

III.A-5

Dose Assessment

Surveillance Design

III.A-6

Annual Design/Review Process

III.A-10

Air Surveillance

III.A-12

Objectives

III.A-13

Plan Rationale and Criteria

III.A-13

Media Selection.

III.A-13

Analyte Selection.

III.A-15

Sampling and Analysis Frequency.

III.A-15

Sampling Location Selection.

III.A-16

Sampling or Measurement Method Selection .................................................................. III.A-17

Sample Handling/Treatment Methods ................................................................ III.A-18

Analytical Methods.

III.A-18

Quality Control Methods

III.A-18

Reporting/Alarm Levels

III.A-18

Exceptions

III.A-18

Surface-Water Surveillance

III.A-18

Objectives

III.A-20

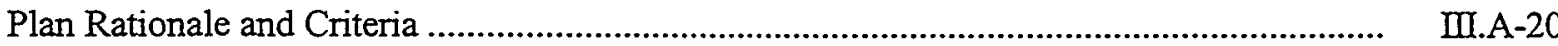

Media Selection .................................................................................................. III.A-20 
Columbia River

III.A-21

Riverbank Springs

III.A-25

Onsite Ponds.

III.A-25

Offsite Irrigation Water

III.A-25

Quality Control Methods

III.A-26

Reporting/Alarm Levels

III.A-26

Exceptions.

III.A-26

Sediment Surveillance

III.A-26

Objectives

III.A-27

Plan Rationale and Criteria

III.A-27

Media Selection

III.A-27

Analyte Selection.

III.A-28

Sampling Frequency

III. $A-28$

Sampling Location Selection

III.A-28

Sample Collection Methods

III.A-29

Analytical Methods

III.A-30

Quality Control Methods

III.A-30

Reporting/Alarm Levels

III.A-30

Exceptions.

III.A-30

Biota and Soil Surveillance

III.A-30

Objectives

III.A-32

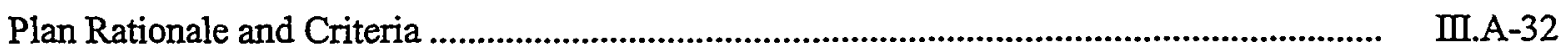

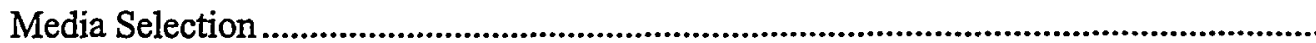

III.A-33

Analyte Selection.

III.A-35

Sampling Frequency.

III.A-36

Sampling Location Selection

III.A -37

Sampling or Measurement Methods

III.A-37

Sample Handling/Treatment Methods

III.A-38

Analytical Methods

III. $A-40$

Quality Control Methods

III. $A-40$

Reporting/Alarm Levels

III.A -40

Exceptions.

III. A -40

III.A-40

External Radiation Surveillance

III.A-41

Objectives

III.A-42

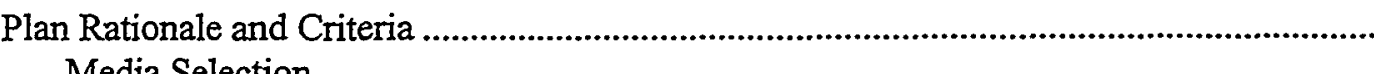

III.A -42

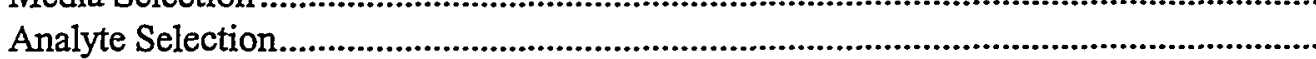

III. A-42

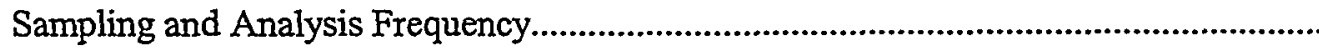

III.A-42

Sampling Location Selection

III.A-43 
Sampling or Measurement Methods Selection .............................................................. III.A-44

Sample Handling/Treatment Methods ........................................................................ III.A-45

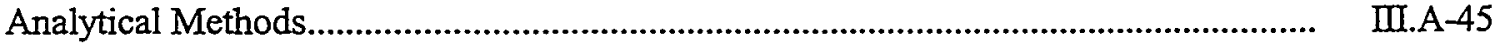

Quality Control Methods ..................................................................................... III.A-45

Reporting/Alarm Levels ....................................................................................... III.A-46

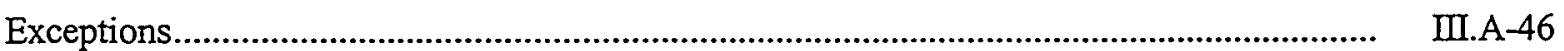

Dose Assessment Methods ................................................................................................ III.A-47

Types of Dose Calculations Performed ................................................................... III.A-47

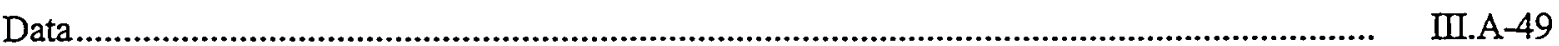

Population Distribution and Atmospheric Dispersion .............................................. III.A 49

Terrestrial and Aquatic Pathways .............................................................................. III.A-50

Public Exposure .................................................................................................. III.A-50

Dose Calculation Documentation............................................................................... III.A-50

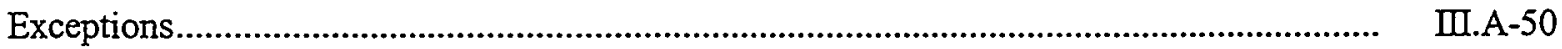

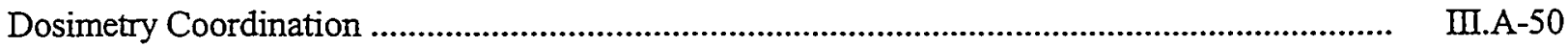

Support for Software, Databases, and Other Risk-Assessment Methods .............................. III.A-51

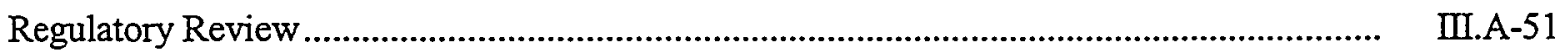

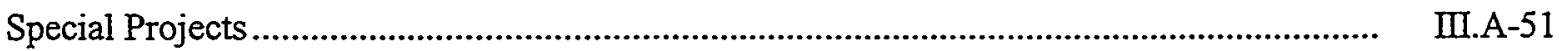

Quality Assurance ......................................................................................... III.A-52

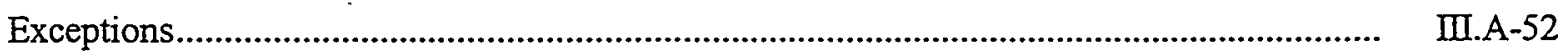

Data Management, Analysis, and Statistical Treatment................................................... III.A-52

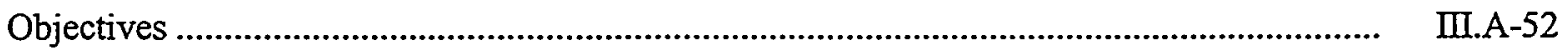

Data Management Overview................................................................................... III.A-53

Sample Scheduling ...................................................................................... III.A-53

Sample Collection............................................................................................... III.A-53

Tracking Sample Collection ........................................................................... III.A-54

Reporting of Analytical Data ............................................................................. III.A-54

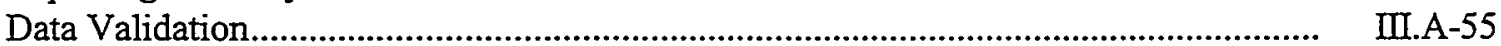

Tracking Sample Analysis .............................................................................. III.A-55

Data Retrieval ......................................................................................................... III.A-55

Database Security ................................................................................................ III.A

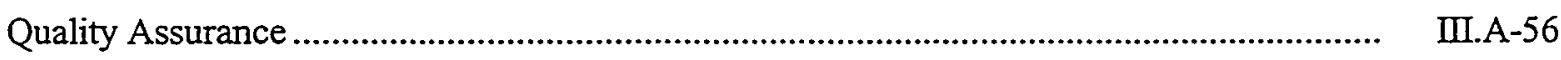


Data Analysis and Statistical Treatment................................................................. III.A-56

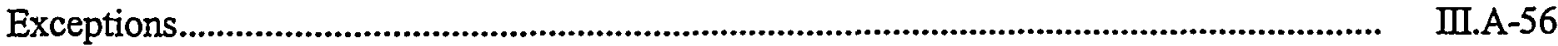

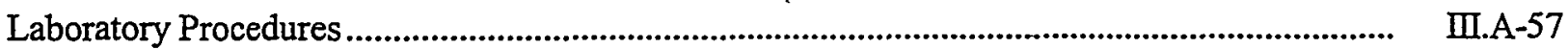

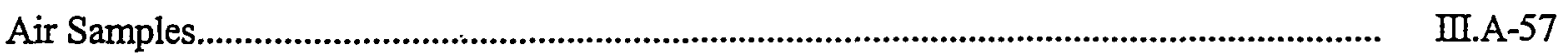

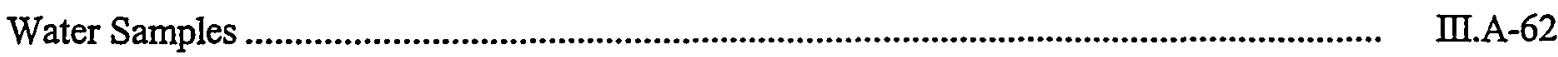

Milk

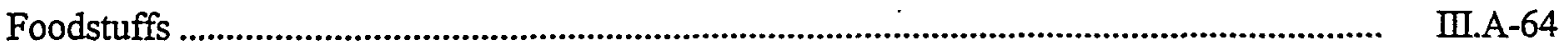

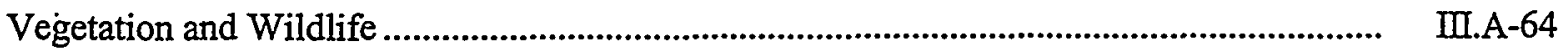

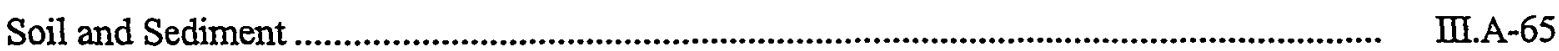

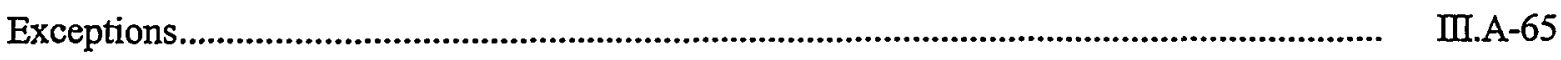

Quality Assurance and Quality Control ....................................................................... III.A-65

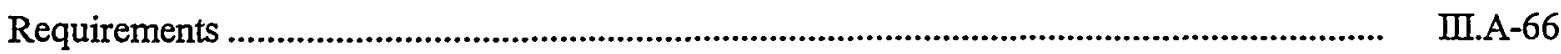

Quality Assurance Plan................................................................................................ III.A-66

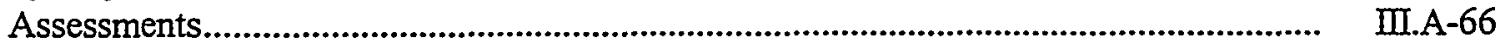

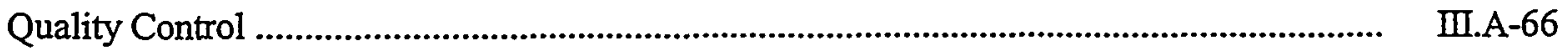

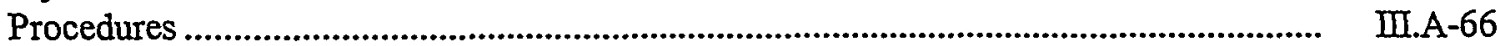

Analytical Quality Control Program ............................................................................. III.A-66

Analytical Accuracy and Precision Criteria ................................................................. III.A-68

Field Radiation Survey Instruments...................................................................... III.A-68

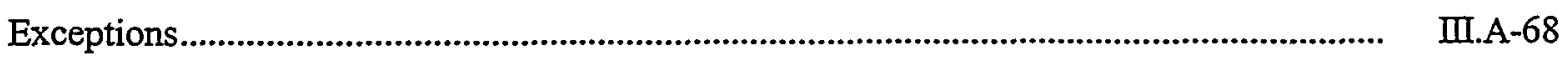

Records Management and Reporting............................................................................ III.A

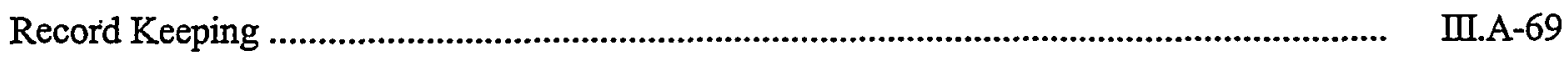

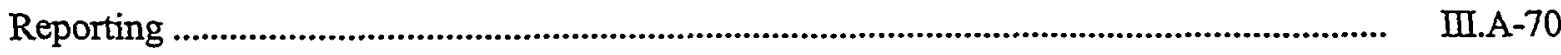

Exceptions...................................................................................................................... III.A-71

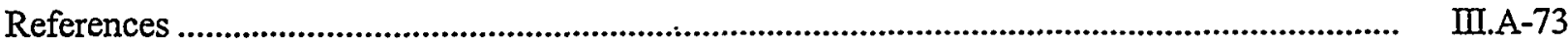

\section{Section III.B. Groundwater Monitoring}

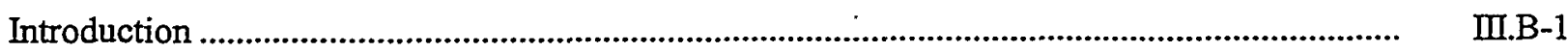

Regulatory Drivers ............................................................................................... III.B-1 
Project Management and Objectives................................................................................ III.B-2

General Groundwater Monitoring Information ...................................................... III.B-3

Construction and Maintenance of Wells.................................................................... III.B-3

Hydrologic Characterization and Modeling............................................................... III.B-4

Water-Level Monitoring .......................................................................................... III.B-4

Groundwater Sampling and Analysis .......................................................................... III.B-5

Data Management and Interpretation..................................................................... III.B-9

Groundwater Monitoring Reports................................................................... III.B-9

Groundwater Monitoring at Regulated Units ........................................................... III.B-10

RCRA Interim Status........................................................................................... III.

RCRA Final Status ........................................................................................ III

CERCLA Past-Practice/RCRA Corrective Action Groundwater Monitoring ....................... III.B-15

Sitewide Environmental Surveillance of Groundwater ...................................................... III.B-17

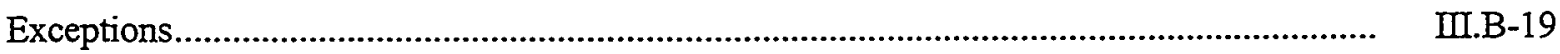

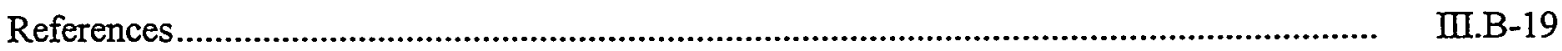

\section{Section III.C. Meteorological Monitoring}

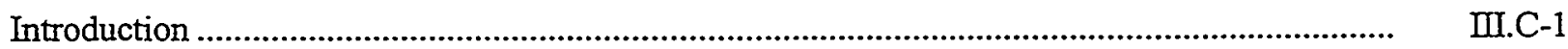

Meteorological and Climatological Services Project .................................................................... II.C-1

Meteorological Monitoring Network................................................................................... III.C-2

Meteorological Instrumentation................................................................................ III.C-2

Instrument Calibration and Maintenance ………….......................................................... III.C-8

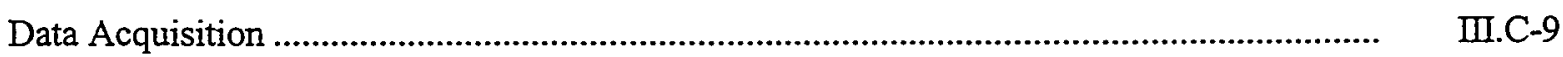

Atmospheric Transport and Diffusion............................................................................... III.C-9

Quality Assurance .................................................................................................. III.C-10

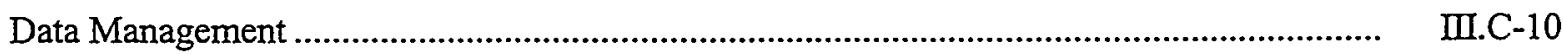

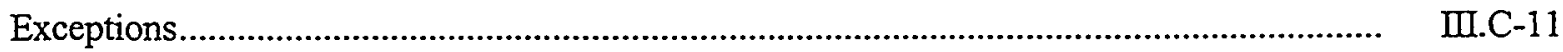

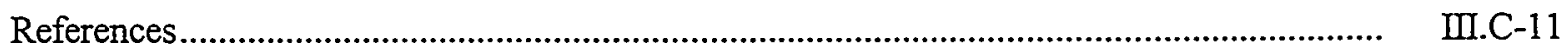




\section{Figures}

I.1 The Hanford Site $\mathrm{I}-4$

III.A-1 Radiation and Chemical Exposure Pathways to Biota

III.A-8

III.A-2 Potential Exposure Pathways to Man

III.A-9

III.A-3 Air Sampling Locations for Calendar Year 2000

III.A-14

III.A-4 Sampling Locations for Surface Water.

III.A-22

III.A-5 Sampling Locations for Sediment.

III.A-29

III.A-6 Sampling Locations for Food and Farm Products in Calendar Year 2000

III.A-34

III.A-7 Sampling Locations for Soil and Vegetation

III.A-38

III.A-8 Sampling Locations for Wildlife, Excluding Background Area

III.A-39

III.B-1 Unconfined Aquifer-Monitoring Wells

III.B-6

III.B-2 Basalt-Confined Aquifer Monitoring Wells

III.B-7

III.B-3 Hanford Site Facilities Requiring Groundwater Monitoring

III.B-11

III.B-4 Groundwater Operable Units on the Hanford Site.

'III.B-16

III.C-1 Meteorological Monitoring Stations on the Hanford Site and in Surrounding Areas ..... III.C-4

\section{Tables}

II.A-1 Facilities Determination Results

II.B-1 Governing Documents.

II. $\mathrm{B}-5$

II.B-2 Near-Field Sampling Media, Frequency, Analytes, and Parameters.

II. $\mathrm{B}-6$

III.A-1 Radiological Monitoring Sampling Summary

III.A-58

III.A-2 Chemical Monitoring Sampling Summary

III.A-61

III.A-3 Accuracy Requirements

III.A-69 
III.A-4 Hanford Site Surface Environmental Surveillance Unusual Concentration

Reporting Levels..

III.A-72

III.B-1 Hanford Site Interim and Final Status Groundwater Monitoring Projects ...................... III.B-13

III.B-2 Groundwater Operable Unit Summary - Environmental Monitoring........................... III.B-17

III.C-1 Hanford Site Meteorological Monitoring Towers................................................. III.C-3 


\title{
Hanford Site Environmental Monitoring Plan
}

\author{
Section I. Introduction
}

\begin{tabular}{|l|l|}
\hline Prepared by: & Date: \\
\hline 1 (w thancurrence: \\
$\begin{array}{l}\text { Robert W. Hanf, Pacific Northwest National } \\
\text { Laboratory }\end{array}$ & $\begin{array}{l}\text { D. C. Ward, U.S. Department of Energy, Richland } \\
\text { Operations Office }\end{array}$ \\
\hline
\end{tabular}




\section{Introduction}

This Environmental Monitoring Plan was prepared pursuant to U.S. Department of Energy (DOE) Order 5400.1 to document the elements of the effluent monitoring and environmental surveillance programs in use at the Hanford Site. When operations and activities take place on the Hanford Site, it is DOE's policy to ensure that the public and the environment are adequately protected through the prevention, control, and abatement of environmental pollution. To this end, DOE is committed to comply with all pertinent federal, state, and local radiation and pollution-control standards, requirements, and policies. At a minimum, the high-priority program elements identified in the guidance document, Environmental Regulatory Guide for Radiological Effluent Monitoring and Environmental Surveillance (DOE/ EH-0173T) are addressed in this plan. The high-priority elements are those that "should*" be performed if the monitoring programs are to be acceptable to DOE.

Initially issued in November 1991, this is the third revision of this plan. Revisions are required by DOE guidance every 3 years. Differences between this revision and the previous revision are relatively small.

The effluent monitoring and environmental surveillance programs currently in place at the Hanford Site are discussed briefly below. Contractor responsibilities and the State of Washington's role in data verification and oversight activities are discussed. An overview of the Hanford Site and a brief discussion of plan changes and responsibilities are also included.

\section{Effluent Monitoring}

Effluent monitoring at the Hanford Site is divided into two categories: 1) facility effluent monitoring and 2) near-facility environmental monitoring. Facility effluent monitoring is performed at each facility by the operating contractor. Within this plan, a facility is defined as a building, structure, or group of buildings that release radionuclides (DOE/EH-0173T). Evaluations of all Hanford Site facilities having the potential to release gaseous or liquid effluents to the environment were conducted, as required by DOE Order 5400.1, through a facility effluent monitoring plan determination process. Plans were prepared for all facilities identified during the determination process as having the potential to discharge contaminants at concentrations exceeding specified exposure levels. Each facility effluent monitoring plan contains the rationale and design criteria for the effluent monitoring program at the facility, information on the extent and frequency of monitoring and measurements, procedures for laboratory analyses, quality assurance requirements, and program implementation procedures. There are currently 13 facilities at the Hanford Site requiring such plans; brief abstracts are included in Section II.A. A table identifying the facilities evaluated during the determination process is also provided.

Near-facility environmental monitoring is conducted by Waste Management Federal Services, Inc., a subsidiary of GTS Duratek. Near-facility environmental monitoring is used to evaluate the adequacy of effluent controls or stabilization efforts near specific facilities or waste disposal sites. Program staff monitor contamination in air, surface water, groundwater, soil, sediment, vegetation, and biota near facilities in the $100,200,300,400$, and 600 Areas. Section II.B of this plan discusses these monitoring 
activities and contains details about the extent and frequency of monitoring and measurements, procedures for laboratory analyses, quality assurance requirements, and program implementation procedures.

\section{Environmental Surveillance}

Environmental surveillance activities at the Hanford Site include 1) surface environment surveillance, 2) groundwater surveillance, and 3) meteorological monitoring.

Section III.A contains the detailed rationale and design criteria for the site's surface environmental surveillance program, extent and frequency of monitoring and measurements, procedures for laboratory analyses, quality assurance requirements, and program implementation procedures. Surface environmental surveillance at the Hanford Site is a multimedia environmental monitoring effort conducted by Pacific Northwest National Laboratory (PNNL) on and off the site to evaluate the environmental impact of Hanford Site operations and to assess offsite human health exposures. Onsite surveillance is conducted independent of facility-related environmental monitoring programs to provide an assessment of the effectiveness of effluent controls. Parameters routinely monitored include air, surface water, sediment, agricultural products, vegetation, soil, and wildlife.

Section III.B describes the site's groundwater monitoring activities managed by PNNL through the Hanford Groundwater Monitoring Project. This project is responsible for assessing the distribution and movement of existing groundwater contamination, both radiological and chemical, and identifying potential and emerging groundwater contamination problems. Monitoring activities are conducted to comply with requirements of the Resource Conservation and Recovery Act of 1976 (RCRA) and State of Washington regulations, as well as requirements for operational monitoring around retired reactors and chemical-processing facilities, and requirements for environmental surveillance. Groundwater monitoring is also carried out during cleanup investigations under the Comprehensive Environmental Response, Compensation, and Liability Act of 1980 (CERCLA). The cleanup monitoring is managed by Bechtel Hanford, Inc., the site's Environmental Restoration Contractor. Groundwater samples are currently collected from approximately 600 wells, both on and off the site. Groundwater information discussed in this plan includes program design, well locations, sampling frequencies, sampling procedures, analyses performed, data reviews, and rationale for the level of effort devoted to each element.

Section II.C describes the rationale and design of the Meteorological and Climatological Services Project, including the number and location of stations, instrumentation, forecasting capability, data management, diffusion modeling, and emergency response capability. This project is managed and conducted by PNNL.

\section{Reporting Requirements}

An annual report, describing the environmental status of the Hanford Site and the surrounding area, is prepared and distributed in accordance with DOE Order 231.1 and applicable DOE-Headquarters' guidance. The Hanford Site environmental report (e.g., PNNL-13230 for 1999) includes data collected and evaluated during the calendar year to characterize environmental management performance and demonstrate compliance status. The report also highlights significant environmental programs and efforts. The report is prepared for DOE by PNNL and other site contractors. Document production and 
coordination are managed by PNNL. Two companion data appendices are also produced. One appendix (e.g., PNNL-13230, APP. 1 for 1999), prepared by PNNL, is a compilation of analytical data for samples collected by staff of the Surface Environmental Surveillance Project during the reporting year. The other document includes analytical data and sampling location maps for the Near-Facility Environmental Monitoring Program. This appendix (e.g., PNNL-13230, APP. 2 for 1999) is prepared by Waste Management Federal Services, Inc. and published by PNNL.

An annual groundwater monitoring report (e.g., PNNL-13116 for 1999) is prepared to meet the reporting requirements of RCRA and various Hanford Site programs. The report is a summary of site groundwater monitoring and provides a comprehensive interpretation of groundwater conditions on the site and in adjacent areas for the reporting year. The report is prepared for DOE by PNNL and other site contractors. Document production and coordination are managed by PNNL.

A radiological emissions report (e.g., DOE/RL-2000-37 for 1999) is prepared for DOE each calendar year in accordance with the Code of Federal Regulations, Title 40, Part 61 (40 CFR 61), Subpart H, and with the requirements of Washington Administrative Code Chapter 246-247. The report documents annual radionuclide air emissions from the Hanford Site and the resulting effective dose equivalent to a hypothetical maximally exposed member of the public. An environmental releases report (e.g., HNF-EP0527-9 for 1.999) is also produced pursuant to the annual environmental release reporting requirements in DOE Orders 5400.1 and 5484.1. The report is a supplement to the Hanford Site environmental report and summarizes the environmental releases from Hanford Site facilities. The emissions report is prepared by Waste Management Federal Services of Hanford, Inc. and PNNL. Document production and coordination are managed by Waste Management Federal Services of Hanford, Inc. The environmental releases report is prepared by Waste Management Federal Services of Hanford, Inc.

In addition, an annual report (e.g., PNNL-13117 for 1999) detailing the results of climatological studies is prepared for DOE by PNNL.

\section{Independent Data Verification and Oversight Activities}

In March 1990, the Washington State Department of Health was awarded a grant from DOE to conduct independent surveillance, oversight, and data verification at the Hanford Site. The grant provides funds for sample collection, analyses, data compilation and interpretation, and report preparation. They publish the results of their independent activities in a report (e.g., WDOH/320-021) produced through their Environmental Radiation Program.

\section{Overview of the Hanford Site}

The Hanford Site lies within the semiarid Pasco Basin of the Columbia Plateau in southeastern Washington State. The Hanford Site occupies an area of approximately 1,517 square kilometers located north of the city of Richland and the confluence of the Yakima River with the Columbia River (Figure I.1). Most of this large area has restricted public access and provides a buffer for the smaller areas onsite that historically were used for producing nuclear materials, waste storage, and waste disposal. Approximately $6 \%$ of the land area has been disturbed and is actively used. The Columbia River flows 


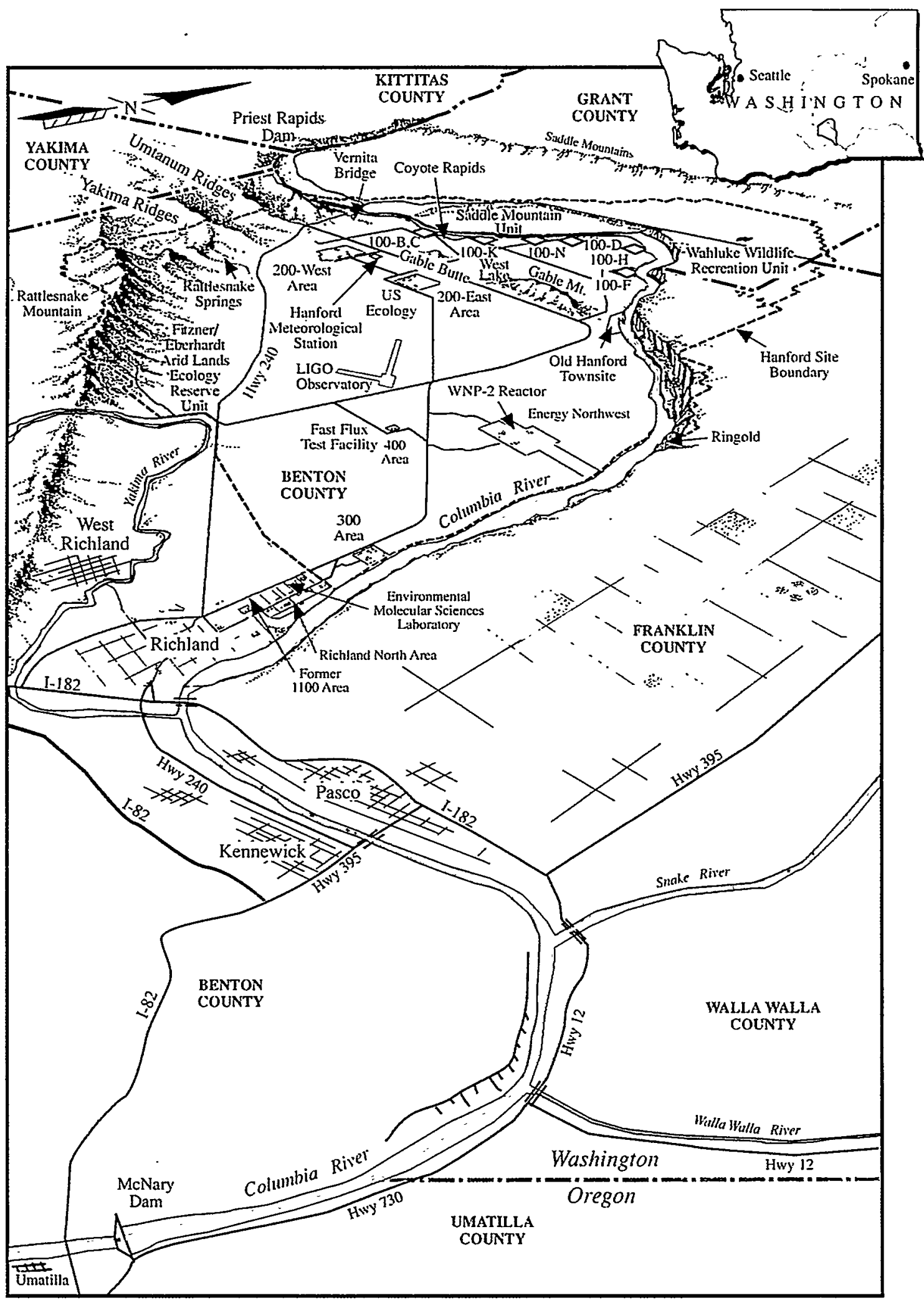

G00100121.2

Figure I.1. The Hanford Site 
eastward through the northern part of the Hanford Site and then turns south, forming part of the eastern boundary. The Yakima River flows along part of the southern boundary and joins the Columbia River downstream from the city of Richland. Land in the surrounding environs is used for urban and industrial development, irrigated and dry-land farming, and livestock grazing.

The Hanford Site was established in 1943 to produce raw material (plutonium) for nuclear weapons and was the first nuclear production facility in the world. The site was selected by the U.S. Army Corps of Engineers because it was remote from major populated areas and had ample electrical power from Grand Coulee Dam, a functional railroad, clean water from the Columbia River, and plenty of onsite sand and gravel for construction. The Hanford Site was divided into a number of operational areas.

Operations at the Hanford Site resulted in the production of liquid, solid, and gaseous waste. Most waste resulting from Hanford Site operations had at least the potential to contain radioactive materials. From an operational standpoint, radioactive liquid waste was originally categorized as high-level, intermediate-level, or low-level, depending on the level of radioactivity present. High-level liquid waste was first stored in large, underground, single-shell tanks. The contents of some of these tanks have since leaked into the soil. In later years, high-level liquid waste was stored in double-shell tanks, which have not leaked waste into the soil. Intermediate-level liquid waste streams were usually routed to various types of underground structures called cribs. Occasionally, trenches were filled with the liquid waste and then covered with soil after the waste had soaked into the ground. Low-level liquid waste was usually disposed in surface impoundments (i.e., ditches and ponds). In most cases, intermediate- and low-level liquid waste was allowed to penetrate the soil to the groundwater. Some of the contaminants that reached the groundwater subsequently flowed with the groundwater into the Columbia River.

The major operational areas on the site include the following:

- The 100 Areas, on the south shore of the Columbia River, are the sites of nine retired plutonium production reactors (100-B, 100-C, 100-D, 100-DR, 100-F, 100-H, 100-KW, 100-KE, 100-N).

- The 200-West and 200-East Areas are located on a plateau and are approximately 8 and 11 kilometers south and west of the Columbia River.

- The 300 Area is located just north of Richland.

- The 400 Area is approximately 8 kilometers northwest of the 300 Area.

- The 600 Area includes all the Hanford Site not occupied by the $100,200,300$, and 400 Areas.

- The Richland North Area (off the site) includes DOE and its contractor facilities, mostly leased office buildings, generally located in the northern part of the city of Richland.

\section{Other Areas}

Several areas of the Hanford Site are now managed by the U.S. Fish and Wildlife Service as the Arid Lands Wildlife Refuge Complex. This complex includes the Fitzner/Eberhardt Arid Lands Ecology 
Reserve unit, the McGee Riverlands unit located on the west boundary of the site, and the Saddle Mountain and Wahluke Wildlife Recreation units located north of the Columbia River.

Non-DOE nuclear operations and activities include commercial power production by Energy Northwest's WNP-2 Reactor (near the 400 Area) and commercial low-level radioactive waste burial at a site leased and licensed by the state of Washington and operated by US Ecology (near the 200 Areas). Near the southern boundary of the Hanford Site, north of Richland, Siemens Power Corporation operates a commercial nuclear fuel fabrication facility, and Allied Technology Group operates a low-level radioactive waste decontamination, super-compaction, and packaging disposal facility and a radioactive mixed waste treatment facility.

\section{Current Site Mission}

For more than 40 years, Hanford Site facilities were dedicated primarily to the production of plutonium for national defense and to the management of the resulting wastes. In recent years, efforts at the site have focused on developing new waste treatment and disposal technologies and cleaning up contamination left over from historical operations.

The Hanford Site has two major missions: 1) environmental management and 2) science and technology. The environmental management mission includes the following:

- management of waste and the handling, storage, treatment, and disposal of radioactive, hazardous, mixed, or sanitary waste from past and current operations

- stabilizing facilities by transitioning them from an operating mode to a long-term surveillance and maintenance mode. This includes maintaining facilities in a safe and compliant status, deactivating primary systems to effectively reduce risks, providing for the safe storage of nuclear materials and reducing risks from hazardous materials and contamination. These activities are intended to allow the lowest surveillance and maintenance cost to be attained while awaiting determination of a facility's final disposition.

- maintaining the Fast Flux Test Facility reactor and its associated support facilities while alternative future missions for the reactor are explored (e.g., medical isotope production)

- maintenance and cleanup of several hundred inactive radioactive, hazardous, and mixed waste disposal sites; remediation of contaminated groundwater; and surveillance, maintenance, and decommissioning of inactive facilities.

The science and technology mission includes the following:

- research and development in energy, health, safety, environmental sciences, molecular sciences, environmental restoration, waste management, and national security 
- developing new technologies for environmental restoration and waste management, including site characterization and assessment methods; waste minimization, treatment, and remediation technology.

\section{Operations/Conditions Change Notification}

The potential exists for facility operations and/or environmental conditions to change during the course of the year. These changes may affect the need for modifications or additions to the existing effluent monitoring and environmental surveillance programs. To ensure that the need for changes can be evaluated and acted on in a timely manner, bimonthly meetings have been established to exchange information about contractor activities and plans for the next 6-month period. Contractors evaluate these operation/condition changes and document the decisions regarding the need for surveillance changes.

This Environmental Monitoring Plan is controlled and maintained by PNNL's Public Safety and Resource Protection Program. Modifications to this plan between revisions will be controlled under existing PNNL project change-control procedures. Substantive deviations from the plan are to be approved by DOE and recorded on the record of changes form.

\section{References}

40 CFR 61, Code of Federal Regulations, Title 40, Part 61, Subpart H. National Emission Standards for Emissions of Radionuclides Other than Radon From Department of Energy Facilities.

Comprehensive Environmental Response, Compensation, and Liability Act of 1980, as amended, Public Law 96-510, 94 Stat. 2767, 42 USC 9601 et seq.

DOE/EH-0173T. 1991. Environmental Regulatory Guide for Radiological Effluent Monitoring and Environmental Surveillance. Assistant Secretary for Environment, Safety and Health, U.S. Department of Energy, Washington, D.C.

DOE Order 231.1. "Environment, Safety, and Health Reporting."

DOE Order 5400.1. "General Environmental Protection Program."

DOE Order 5484.1. "Environmental Protection, Safety, and Health Protection Information Reporting Requirements."

DOE/RL-2000-37. 2000. Radionuclide Air Emissions Report for the Hanford Site, Calendar Year 1999. D. J. Rokkan, Fluor Hanford, Inc., and K. Rhoads, Pacific Northwest National Laboratory, for the U.S. Department of Energy, Richland Operations Office, Richland, Washington.

HNF-EP-0527-9. 2000. Environmental Releases for Calendar Year 1999. D. J. Rokkan, Waste Management Federal Services, Inc., Richland, Washington. 
PNNL-13116. 2000. Hanford Site Groundwater Monitoring for Fiscal Year 1999. M. J. Hartman, L. F. Morasch, and W. D. Webber (eds.), Pacific Northwest National Laboratory, Richland, Washington.

PNNL-13117. 2000. Hanford Site Climatological Data Summary 1999, With Historical Data. D. J. Hoitink, K. W. Burk, and J. V. Ramsdell, Pacific Northwest National Laboratory, Richland, Washington.

PNNL-13230. 2000. Hanford Site Environmental Report for Calendar Year 1999. T. M. Poston and R. W. Hanf (eds.), Pacific Northwest National Laboratory, Richland, Washington.

PNNL-13230, APP. 1. 2000. Hanford Site Environmental Surveillance Data Report for Calendar Year 1999. L. E. Bisping, Pacific Northwest National Laboratory, Richland, Washington.

PNNL-13230, APP. 2. 2000. Hanford Site Near-Facility Environmental Monitoring Data Report for Calendar Year 1999. C. J. Perkins, B. M. Markes, S. M. McKinney, R. M. Mitchell, and R. C. Roos. Prepared by Waste Management Federal Services, Inc. and submitted by Pacific Northwest National Laboratory, Richland, Washington.

Resource Conservation and Recovery Act of 1976, as amended, Public Law 94-580, 90 Stat. 2795, 42 USC 6901 et seq.

WDOH/320-021. 1999. Environment Radiation Program 1992-1994 Annual Report, 31st Edition. Washington State Department of Health, Olympia, Washington.

WAC 246-247, Washington Administrative Code. Radiation Protection - Air Emissions. Olympia, Washington. 


\section{Hanford Site Environmental Monitoring Plan}

\section{Section II.A. Facility Effluent Monitoring Plans}

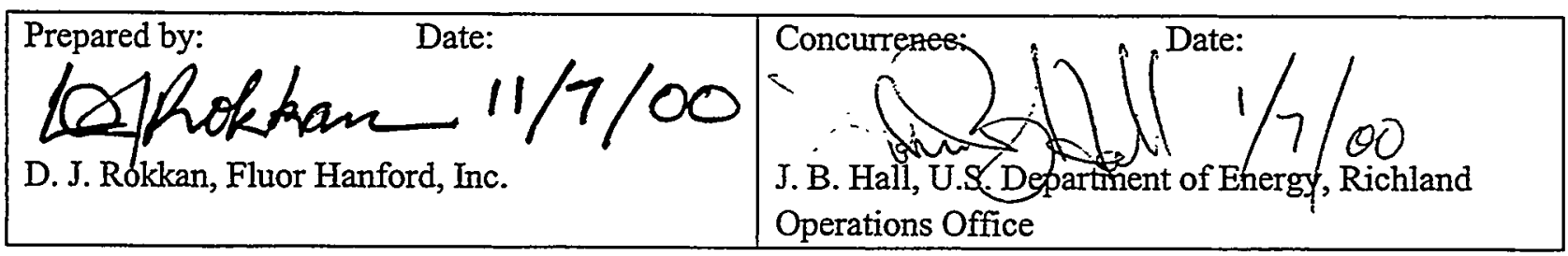




\section{Introduction}

This section addresses facility effluent monitoring plans that are completed and implemented to meet the overall radioactive and nonradioactive monitoring requirements of U.S. Department of Energy (DOE) Order 5400.1 and DOE/EH-0173T. New or modified facilities are evaluated to determine if a facility effluent monitoring plan is needed; if so, a plan will be completed before startup, in accordance with the guidance document for these plans (WHC-EP-0438-1).

The effluent and emission monitoring activities for all media, with the exception of groundwater, are addressed by the facility effluent monitoring plans. The monitoring of liquid effluents for nonradioactive hazardous constituents, as defined by the Resource Conservation and Recovery Act of 1976 (RCRA), is covered in the site-specific sampling analysis plan. Two activities associated with the facility effluent monitoring plans are the determination of the need for a plan and the preparation of the plan. The facility effluent monitoring plan determination consists of an initial evaluation of potential radioactive or hazardous material sources within a facility. If a significant quantity of radioactive or hazardous material is present, then a facility effluent monitoring plan is prepared.

\section{Determination of Need for a Facility Effluent Monitoring Plan}

The facility effluent monitoring plan determinations were prepared for individual Hanford Site facilities. In many cases, facilities were grouped by area and the following information was included in each plan determination document:

- an introduction section that includes the current configuration and status of each facility (active, inactive, standby)

- an information section that includes a brief facility/ process description

- a discussion section that includes source-term identification and characterization, radiological/ hazardoús material inventories at risk, fugitive sources (where applicable), identification of release pathway and effluent point of discharge, and identification and characterization of source terms contributing to each effluent stream

- a section that describes the potential upset conditions (assuming failure of a single barrier) for each event, along with the type and amount of material involved, the pathway for potential release, and the offsite dose calculations to be evaluated against the Clean Air Act Amendments of 1990, Code of Federal Regulations, Title 40, Part 61 (40 CFR 61), Subpart H, and the Washington Administrative Code (WAC) $173-480$ 
- a summary section that evaluates the relevant data to determine whether the facility requires a facility effluent monitoring plan

- an attachment entitled "Determination of FEMP Requirement" from the guidance document (WHC-EP-0438-1).

Pacific Northwest National Laboratory (PNNL) used a slightly different approach to determine the need for facility effluent monitoring plans because projects within these facilities are continually changing. Facilities meeting the radiological emission criteria described in the next section were determined to require individual facility effluent monitoring plans. In addition, a Balance-of-Plant Facility Effluent Monitoring Plan was prepared for all other DOE-owned facilities operated by PNNL to allow for highly variable inventories and processes within a defined effluent sampling and monitoring envelop.

\section{Radiological Emissions}

Pursuant to 40 CFR 61 and DOE Order 5400.1, a facility effluent monitoring plan was prepared for those facilities having the potential to release quantities of airborne radioactive materials that could cause radiation doses in excess of 0.1 millirem per year effective dose equivalent (EDE) to the maximally exposed individual. A facility effluent monitoring plan was also prepared for any facility discharging a liquid effluent regulated by 40 CFR 122 and containing sufficient radionuclides to cause an EDE greater than 4.0 millirems per year in any person exposed to the effluent. The release quantities were evaluated at the point of release, assuming no pollution-control equipment was in place, but operations were otherwise normal (including expected upset conditions). In this determination process, over 160 potential sources across the Hanford Site were evaluated (HNF-1974, PNNL-10855). Dose calculation methods and summaries of the facility effluent monitoring plan determinations are given in HNF-1974 and PNNL-10855.

\section{Nonradiological Emissions}

A facility effluent monitoring plan was also prepared for any facility having the potential to release large quantities of nonradioactive hazardous materials that would exceed the reportable quantities listed in 40 CFR 302.4.

In addition to the facility effluent monitoring plan, RCRA requires a sampling and analysis plan to monitor nonradioactive liquid effluent streams. These plans characterize liquid effluent discharges, account for variations in volumes and contaminant concentrations from operational practices, and consider all the parameters known or suspected to be associated with each liquid effluent stream, such as the influence of operational practices, raw-water characteristics, and process knowledge. The results of data analysis are compared against the list of hazardous substances in WAC 173-200 to identify any exceedances and to ascertain compliance with regulations. The results are used to assess the potential for contamination in soil and groundwater.

This sampling complements the routine environmental monitoring program at the Hanford Site and allows analysis of the nonradioactive constituents in the liquid waste streams that are not included in 
other environmental monitoring programs. Results of the sampling efforts are compiled and archived in the Liquid Effluent Monitoring Information System (LEMIS).

\section{Facility Effluent Monitoring Plan Preparation}

Prime contractors are required, as necessary, to produce facility effluent monitoring plans for the Hanford Site facilities they manage. PNNL performs a similar function for the DOE facilities it manages. DOE is informed in a timely manner of any changes to the facility effluent monitoring plans.

DOE Order 5400.5 and DOE/EH-0173T require a quality assurance plan, covering all environmental monitoring activities at the Hanford Site, to be prepared consistent with applicable elements of the American Society of Mechanical Engineers (ASME) NQA-1. Further, QAMS-005/80 is applicable, and such quality assurance plan is included or referenced in each individual facility effluent monitoring plan.

The quality assurance objectives for the monitoring of liquid effluents and air emissions are discussed in WHC-EP-0446-2. The quality assurance objectives for compiling and reporting air emission monitoring are defined in HNF-EP-0528-3.

The facility effluent monitoring plans are prepared in the format specified in HNF-PRO-3679. Each plan includes the following:

- an introduction, including purpose, scope, and discussion of constituents and applicable regulations

- a description of the facility, process, potential sources, and release pathways

- a characterization of effluent discharges (both airborne and liquid) that are monitored and the potential contaminant concentrations

- an identification and characterization of the effluent-discharge points (both airborne and liquid) and a discussion of the design criteria and technical specifications pertaining to the effluent monitoring/ sampling systems

- a discussion of monitoring and assessment methods different from those specified by the U.S. Environmental Protection Agency and the 5400-series of DOE Orders

- historical monitoring/sampling data (if available) and a comparison of data for normal and upset conditions

- information regarding sample analysis, including laboratory procedures

- notification and reporting requirements 
- interface with the Hanford Groundwater Monitoring Project (managed by PNNL)

- a discussion of quality assurance

- a discussion of internal and external reviews, approvals of changes, and annual reviews

- a discusssion of compliance with applicable DOE Orders and U.S. Environmental Protection Agency regulations

- conclusions, exceptions or exemptions and justifications, and required system upgrades

- applicable references.

The PNNL facility effluent monitoring plans are in a slightly different format but contain the bulleted information above, as applicable.

Table II.A-1 lists the facilities on the Hanford Site that contain radioactive material, the prime contractor responsible for managing the facility, and the need for a facility effluent monitoring plan. Because it is not feasible to include each individual facility effluent monitoring plan in this Environmental Monitoring Plan, an abstract from each noted with a "yes" in Table II.A-1 follows.

Table II.A-1. Facilities Determination Results

\begin{tabular}{|c|c|c|}
\hline Facility & Manager & FEMP Required? \\
\hline \multicolumn{3}{|l|}{100 Areas } \\
\hline 105-KE/KW Fuel Storage Basins & FH & Yes \\
\hline 105-KW Integrated Water Treatment System Air Sparging & FH & Yes \\
\hline Cold Vacuum Drying Facility & $\mathrm{FH}$ & Yes \\
\hline N Electrical Shop & $\mathrm{BHI}$ & No \\
\hline N Paint Shop & $\mathrm{BHI}$ & No \\
\hline Retired Reactors (B, C, D, DR, F, H, N) & $\mathrm{BHI}$ & No \\
\hline \multicolumn{3}{|c|}{ 200/600 Areas } \\
\hline B Plant & $\mathrm{BHI}$ & Yes \\
\hline Batch Plant & FH & No \\
\hline Canister Storage Building & $\mathrm{FH}$ & Yes \\
\hline Fabrication Shops & $\mathrm{FH}$ & No \\
\hline General Area Services (200 Areas) & $\mathrm{FH}$ & No \\
\hline Low-Level Burial Grounds & $\mathrm{FH}$ & No \\
\hline Plutonium Finishing Plant & FH & Yes \\
\hline Plutonium-Uranium Extraction (PUREX) Plant & $\mathrm{BHI}$ & Yes \\
\hline PUREX Pipefitter Shop & $F H$ & No \\
\hline Solid Waste Facilities Compactor & $\mathrm{FH}$ & No \\
\hline
\end{tabular}


Table II.A-1. (contd)

\begin{tabular}{|c|c|c|c|c|c|c|}
\hline \multicolumn{3}{|c|}{ Facility } & Manager & \multicolumn{3}{|c|}{ FEMP Required? } \\
\hline T Plant & & & $\mathrm{FH}$ & & No & \\
\hline \multicolumn{7}{|c|}{ Tank Farm Complex } \\
\hline \multicolumn{7}{|c|}{ Single-Shell Tank Farms } \\
\hline $241-A$ & $241-\mathrm{AX}$ & $241-B$ & CHG & No & No & No \\
\hline 241-BX & 241-BY & $241-C$ & CHG & No & Yes & Yes \\
\hline $241-S$ & 241-SX & 241-TX & $\mathrm{CHG}$ & No & Yes & No \\
\hline 241-TY & $241-U$ & & CHG & No & No & \\
\hline \multicolumn{7}{|c|}{ Double-Shell Tank Farms } \\
\hline 241-AN & 241-AP & 241-AW & CHG & No & No & No \\
\hline 241-SY & 244-A & 244-TX & $\mathrm{CHG}$ & No & Yes & Yes \\
\hline $244-U$ & 244-S & 244-BX & $\mathrm{CHG}$ & No & Yes & Yes \\
\hline 241-AY & $241-A Z$ & & $\mathrm{CHG}$ & Yes & Yes & \\
\hline \multicolumn{7}{|l|}{ Vaults } \\
\hline 204-AR & 244-AR & 244-CR & CHG & No & Yes & Yes \\
\hline \multicolumn{7}{|c|}{ Evaporators } \\
\hline $242-S$ & $242-T$ & & CHG & No & No & \\
\hline $242 \mathrm{~A}$ & & & $\mathrm{FH}$ & & No & \\
\hline U Plant & & & $\mathrm{BHI}$ & & No & \\
\hline Waste Encaps & on and Sto & Facility & FH & & Yes & \\
\hline Waste Receiv & ind Proces & (WRAP) Facility & FH & & Yes & \\
\hline Waste Sampli & ad Charact & tion Facility (WSCF) & FH & & No & \\
\hline $224-U\left(\mathrm{UO}_{3}\right)$ & & & $\mathrm{BHI}$ & & No & \\
\hline 200 Areas Ef & t Treatmer & iility (ETF) & $\mathrm{FH}$ & & No & \\
\hline 200 Areas $\operatorname{Tr}$ & Effluent I & sal Facility (TEDF) & FH & & No & \\
\hline 200-E Darkro & & & FH & & No & \\
\hline 200-E Electri & hop & & FH & & No & \\
\hline 200-W Paint & & & $\mathrm{FH}$ & & No & \\
\hline 202-S (Reduc & Oxidation & DOX] Plant) & $\mathrm{BHI}$ & & No & \\
\hline $\begin{array}{l}\text { 212-P Nonrac } \\
\text { Facility }\end{array}$ & tive Polyc & nated Biphenyl Storage & $\mathrm{FH}$ & & No & \\
\hline 222-S Labora & & & $\mathrm{FH}$ & & No & \\
\hline 224-T Transu & Waste St & and Assay Facility & FH & & No & \\
\hline 233-S Facility & & & $\mathrm{BHI}$ & & No & \\
\hline 242-B Facilit & & & PNNL & & No & \\
\hline $284-E$ and 29 & Powerplar & & FH & & No & \\
\hline 2703-E Clinic & avironmen & aboratory & FH & & No & \\
\hline 2711-E Facili & & & FH & & No & \\
\hline 2718-E Facili & & & PNNL & & No & \\
\hline
\end{tabular}


Table II.A-1. (contd)

\begin{tabular}{|c|c|c|}
\hline Facility & Manager & FEMP Required? \\
\hline 2911-E Facility & FH & No \\
\hline Fitzner/Eberhardt Arid Lands Ecology Reserve (6652) & PNNL & No \\
\hline Purge Water Storage and Treatment Facility (600 Area) & $\mathrm{FH}$ & No \\
\hline $213-\mathrm{J}$ and $213-\mathrm{K}$ Storage Vaults (600 Area) & $\mathrm{FH}$ & No \\
\hline 616 Nonradioactive Dangerous Waste Storage Facility & FH & No \\
\hline $622-\mathrm{R}$ Facility & PNNL & No \\
\hline \multicolumn{3}{|c|}{300 Area } \\
\hline 300 Area Paint Shop & FH & No \\
\hline 300 Area Treated Effluent Disposal Facility & FH & No \\
\hline $300-N$ Facility & PNNL & No \\
\hline 303-A, B, C, E, F, G, K & $\mathrm{FH}$ & No \\
\hline 303-M Oxide Facility & $\mathrm{FH}$ & No \\
\hline 305-B Facility & PNNL & No \\
\hline 305 Hot Cell Verification & $\mathrm{FH}$ & No \\
\hline 306-E Fabrication and Testing Laboratory & FH & No \\
\hline 306-W Facility & PNNL & No \\
\hline 308 Fuels Laboratory & BHI & No \\
\hline 309 SP-100 Facility & $\mathrm{FH}$ & No \\
\hline 313 and 333 Fuels Fabrication Facilities & $\mathrm{FH}$ & No \\
\hline 314 Facility & PNNL & No \\
\hline 318 Facility & PNNL & No \\
\hline 320 Facility & PNNL & No \\
\hline 321 Facility & $\mathrm{FH}$ & No \\
\hline 323 Facility & PNNL & No \\
\hline 324 Facility & FH & Yes \\
\hline 325 Building & PNNL & Yes \\
\hline 326 Facility & PNNL & No \\
\hline 327 Facility & $\mathrm{FH}$ & Yes \\
\hline 328 Technical Shops & FH & No \\
\hline 329 Facility & PNNL & No \\
\hline 331 Facility & PNNL & Yes \\
\hline 331-G Facility & PNNL & No \\
\hline 331-H Facility & PNNL & No \\
\hline 334-A Spent Acid Storage & FH & No \\
\hline 335/335A Facility & FH & No \\
\hline 337 High-Temperature Sodium Facility & FH & No \\
\hline 338 Maintenance & $\mathrm{FH}$ & No \\
\hline
\end{tabular}


Table II.A-1. (contd)

\begin{tabular}{|c|c|c|}
\hline Facility & Manager & FEMP Required? \\
\hline 340 Complex & $\mathrm{FH}$ & Yes \\
\hline 377 Facility & FH & No \\
\hline 382 Facility & FH & No \\
\hline 384 Powerhouse & FH & No \\
\hline 3020 Environmental Molecular Sciences Laboratory & PNNL & No \\
\hline 3621B/C/D Facility & FH & No \\
\hline 3703 Facility & $\mathrm{FH}$ & No \\
\hline 3704 Facility & FH & No \\
\hline 3705 Photo Laboratory & FH & No \\
\hline 3706 Facility & $\mathrm{FH}$ & No \\
\hline 3707 Facility & $\mathrm{FH}$ & No \\
\hline 3709 Paint Shop & FH & No \\
\hline 3717-B Standards Laboratory & FH & No \\
\hline 3718-F Alkali Metal & FH & No \\
\hline 3720 Facility (Material Science Laboratory) & PNNL & Yes \\
\hline 3722 Facility & FH & No \\
\hline 3730 Facility & PNNL & No \\
\hline 3732 Facility & FH & No \\
\hline 3745 Facility & PNNL & No \\
\hline 3765 Facility & $\mathrm{FH}$ & No \\
\hline 3790 Facility & $\mathrm{FH}$ & No \\
\hline \multicolumn{3}{|c|}{400 Area } \\
\hline Fast Flux Test Facility & $\mathrm{FH}$ & No \\
\hline Fuels and Materials Examination Facility & FH & No \\
\hline Maintenance and Storage Facility & FH & No \\
\hline 4722 B,C Maintenance & FH & No \\
\hline 4734-B Maintenance & FH & No \\
\hline 4831 Flammable Storage & FH & No \\
\hline 4843 Alkali Metal Storage & FH & No \\
\hline \multicolumn{3}{|c|}{700 Area } \\
\hline 747 Building & HEHF & No \\
\hline 747-A Facility & PNNL & No \\
\hline
\end{tabular}


Table II.A-1. (contd)

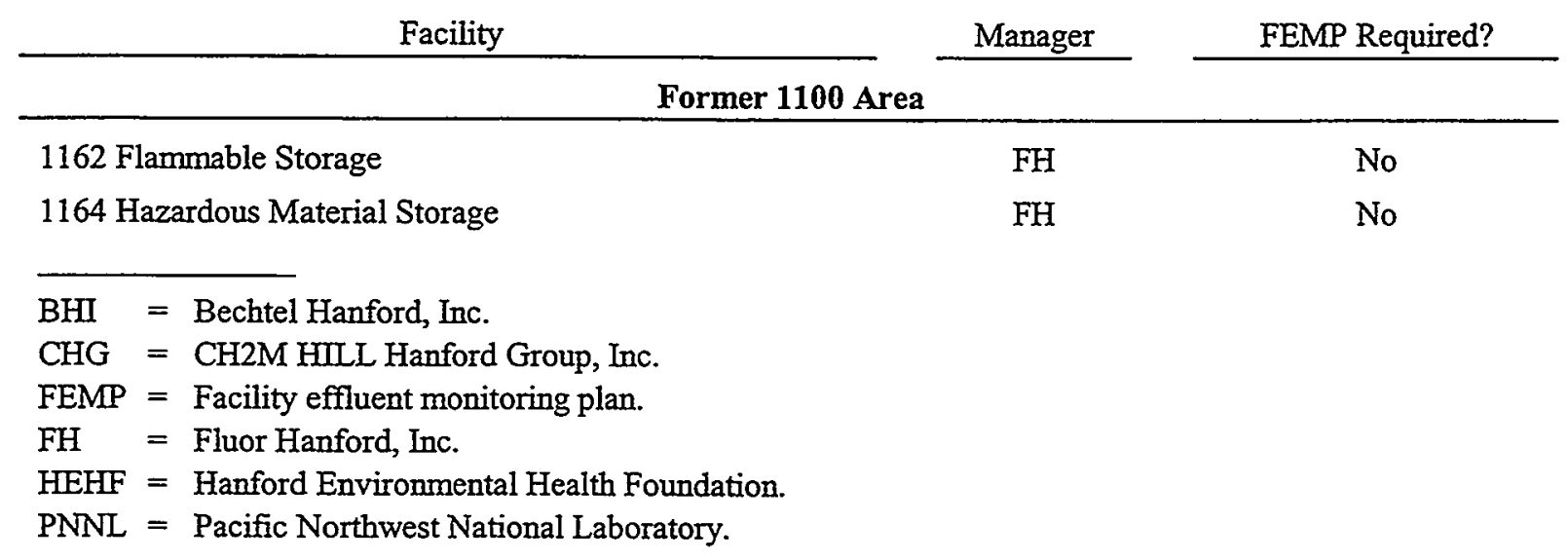

\section{Environmental ALARA Program}

The Hanford Site will implement an integrated environmental ALARA (as low as reasonably achievable) program in accordance with DOE Order 5400.5 and 10 CFR 834 (when promulgated). The program will include 1) the management policy and statement of commitment to the ALARA philosophy, 2) the organizational responsibilities and authority and structure for implementation, 3) an evaluation of site operations that identifies activities responsible for radioactive releases that could cause a radiation exposure to the public and/or environment, and 4) an overall procedure for analyzing existing and proposed operations and activities to ensure ALARA is practiced. Further, the program will be designed to identify general areas to be considered in environmental ALARA decisions (societal, technological, economic, public policy). A checklist of evaluation factors, staff requirements, and required records, in addition to the programs already in place on the Hanford Site, will be developed. Fluor Hanford, Inc., Bechtel Hanford, Inc., CH2M HLL Hanford Group, Inc., and PNNL each have the responsibility to prepare an environmental ALARA program plan.

\section{Potential Unmitigated Doses from Hanford Facilities}

Sources of, and potential radiation doses from, airborne releases from Hanford Site facilities are calculated to determine whether a radiation release could result in a dose to the maximally exposed individual of greater than 0.1 millirem per year EDE. A facility effluent monitoring plan is needed for any facility that exceeds this dose level. These determinations are documented and updated on a regular basis. PNNL determinations are calculated from a comprehensive inventory of radionuclides (PNNL10855 describes the method used). Determinations for Bechtel Hanford, Inc., CH2M HILL Hanford Group, Inc., and Fluor Hanford, Inc. are documented in HNF-1974, and were based on the dose conversion factors in HNF-3602, Vol. 1. 


\section{Facility Effluent Monitoring Plan Abstracts}

The facility effluent monitoring plans prepared for the affected facilities given in Table II.A-1 are summarized on the following pages.

\section{Spent Nuclear Fuels Project}

The Hanford Spent Nuclear Fuels Project is located in the 100-K and 200-East Areas and has been established to manage the safe storage of spent nuclear fuel at the Hanford Site in anticipation of future final disposition. The scope of the Hanford Spent Nuclear Fuel Project covers the maintenance and operation of the $\mathrm{KE}$ and $\mathrm{KW}$ Basins for removal and safe storage of the spent nuclear fuel, debris, sludge, and water, as necessary, and operation of the Cold Vacuum Drying Facility to condition the fuel; operation of the Canister Storage Building to store the fuel prior to final disposition; relocation of the $\mathrm{K}$ Basin spent nuclear fuel (via the multi-canister overpack and cask-transportation system) to the interim storage facility; removal and pretreatment of the $\mathrm{K}$ Basin sludge for disposal; consolidation of the spent nuclear fuel from other Hanford locations at the 200-East interim storage area; and deactivation of the $100-\mathrm{K}$ Area facilities (includes basin water removal) that are under the purview of the Hanford Spent Nuclear Fuel Project for eventual decontamination and decommissioning by the Environmental Restoration Program.

\section{KE and KW Fuel Storage Basins}

These fuel storage basins are located in the 100-K Area adjacent to the Columbia River. The KE and $\mathrm{KW}$ Reactors have been shut down, deactivated, and decommissioned. Most of the stored fuel from the $\mathrm{KE}$ and $\mathrm{KW}$ Reactors was shipped to the 200-East Area reprocessing facilities, leaving the basins largely empty. Because of an impending shortage of storage space at the N Reactor in the 1970s for its own irradiated fuel, the $\mathrm{K}$ Basins were cleaned and modified to store that fuel. With the closure of $\mathrm{N}$ Reactor, eventually all of its remaining fuel was shipped to the $\mathrm{K}$ Basins. The basin-cooling systems were modified to a closed system, and a leak in the KE Basin was repaired. Storage of $N$ Reactor fuel in the basins started in 1975 and continues to the present, but shipments from the reactor ceased in 1989. The Hanford Groundwater Monitoring Project, managed by PNNL, monitors the groundwater adjacent to the basins to detect leaks.

Modifications to the $\mathrm{KW}$ Basin have been made for the purpose of retrieving, packaging, and removing the fuel from the basin. The modifications include equipment for air sparging of the water treatment filters. This sparging is a separate emission point and is called the 105-KW Air Sparging Vent. Similar modifications are planned for the $\mathrm{KE}$ Basin.

The 100-K Area has one liquid effluent discharge to the Columbia River: the 1908-KE Outfall (i.e., National Pollutant Discharge Elimination System [NPDES] Outfall 004). 


\section{Cold Vacuum Drying Facility}

The Cold Vacuum Drying Facility removes free water from metallic uranium and prepares spent nuclear fuel for storage in a helium atmosphere. The spent nuclear fuel will be packaged into waterfilled multi-canister overpacks and removed from the $\mathrm{KE}$ and $\mathrm{KW}$ Basins. Removal of free water is necessary to halt water-induced corrosion of exposed uranium surfaces and to allow the overpacks to be transported safely to the Hanford Site 200-East Area and stored within the Canister Storage Building.

The Cold Vacuum Drying Facility is located within a few hundred meters of the $100-\mathrm{K}$ Area basins just southwest of the 165-KW Power Control Building and the 105-KW Reactor Building.

\section{Canister Storage Building}

The Canister Storage Building is a structural steel, above grade structure with metal siding, which encloses the load-in/load-out area, and has three equal size, below grade concrete vaults covered by a concrete operating deck. Support equipment is housed in a steel building located at the north side of the operations building. Only the northernmost vault is equipped with steel tubes for staging and storage of the multi-canister overpacks. The storage tubes are supported from the foundation of the vault and are accessed through tube plugs in the operating deck. The multi-canister overpack storage vault is cooled by natural convection through the above grade, dedicated concrete and steel inlet structure and exhaust air stack and below grade reinforced concrete plenum.

\section{Airborne Effluents}

Airborne effluent streams evaluated include those from the KE and $\mathrm{KW}$ Basins, the 105-KW Integrated Water Treatment System Air Sparging Vent, 1706-KE Complex Counting Facility, the Cold Vacuum Drying Facility stack, and the Canister Storage Building stack. Radionuclides discharged to the air may include americium-241, antimony-125, cesium-134, cesium-137, cobalt-60, europium-155, plutonium-238, plutonium-239/240, and strontium-90.

\section{Liquid Effluents}

Two liquid streams located at the 1908-KE Outfall (i.e., NPDES Outfall 004 and NPDES MultiSector Storm Water Permit) are routinely sampled to determine permit compliance. The outfall streams are monitored for radionuclides from past reactor operations, such as cesium-137, cobalt-60, plutonium-239/240, strontium-90, and tritium. The outfall discharges to the Columbia River.

\section{Facility Effluent Monitoring Plan Determination}

A facility effluent monitoring plan is required because of the potential for the liquid effluents to contain radiological contamination from the 1908-KE Outfall from past reactor operations and the potentialto-emit from the stacks associated with the storing and processing of the spent nuclear fuel. The facilities with a potential-to-emit greater than 0.1 millirem per year are the 105-KW Air Sparging Vent, the Cold Vacuum Drying Facility stack, and the Canister Storage Building stack. The facility effluent monitoring plan (HNF-EP-0497) was issued in August 2000. 


\section{B Plant}

B Plant is located in the 200-East Area. The plant was originally designed to chemically process spent nuclear fuel but was later modified to individually separate strontium- 90 and cesium- 137 from the Plutonium-Uranium Extraction (PUREX) Plant fission-product waste stream. The cesium-137 and strontium-90 were then encapsulated at the Waste Encapsulation and Storage Facility, and the remaining waste was transferred to the tank farms. B Plant is a permitted storage, treatment, and disposal facility currently operating under interim status with an approved Part A permit. Currently, B Plant is a facility being prepared for shutdown. Its sole mission is to support the safe management and storage of its residual radionuclide inventory. There are currently no production activities at B Plant.

\section{Airborne Effluents}

Airborne effluent streams from B Plant include those from the 296-B-1 and 296-B-2 stacks. The 296-B-1 stack has a real-time monitor. The new 296-B-2 stack is passively ventilated, and its low emissions are verified by nondestructive analysis of the most downstream high-efficiency particulate air filter. Radionuclide constituents of interest include cesium-137 and strontium-90.

\section{Liquid Effluents}

The liquid effluent streams at B Plant are inactive at this time except for the cooling water that now discharges to the 200 Areas Treated Effluent Disposal Facility (TEDF).

\section{Facility Effluent Monitoring Plan Determination}

A plan is required because of the potential for radionuclide concentrations in the airborne effluents from the 296-B-1 and 296-B-10 stacks to cause a dose to the maximally exposed individual of greater than 0.1 millirem per year EDE. The facility effluent monitoring plan (BHI-01371) was issued in August 2000 .

\section{Waste Encapsulation and Storage Facility}

The current Waste Encapsulation and Storage Facility (WESF) mission is to store cesium-137 and strontium-90 capsules in a safe manner and in compliance with all applicable rules and regulations. There are currently no production activities at WESF. WESF is a permitted storage facility. Capsules will be stored until 2017.

\section{Airborne Effluents}

The airborne effluent stream from WESF is from the 296-B-10 stack, which has a real-time monitor. Radionuclide constituents of interest include cesium-137 and strontium-90.

\section{Liquid Effluents}

The liquid effluent streams from WESF did include the former B Plant chemical sewer, cooling water, sanitary sewer, and french drains, all of which are now inactive. 


\section{Plutonium Finishing Plant}

- This plant is located in the 200-West Area and consists of one primary processing facility and several ancillary buildings (i.e., 234-5Z, 236-Z, 232-Z, 241-Z, 242-Z, 243-Z, 270-Z, 291-Z, 2736-Z, 2736-ZA, and 2736-ZB). Hazardous material inventories include acetone, carbon tetrachloride, hydrochloric acid, hydrogen chloride, nitric acid, and oxides of nitrogen. Principle radionuclides include americium-241, plutonium-238, plutonium-239, and plutonium-241.

\section{Airborne Effluents}

One gaseous effluent stream (291-Z-1 stack), which has a real-time monitor, was determined to require a facility effluent monitoring plan based on the potential for the calculated EDE to the maximally exposed individual to exceed 0.1 millirem per year.

\section{Liquid Effluents}

All liquid effluent streams are inactive at this time.

\section{Facility Effluent Monitoring Plan Determination}

A plan is required for the Plutonium Finishing Plant because of the potential for radionuclide concentrations in airborne effluents from the 291-Z-1 stack to cause a dose to the maximally exposed individual of greater than 0.1 millirem per year EDE. Revision 2 of the facility effluent monitoring plan (HNF-EP-0476) was approved in April 2000.

\section{Plutonium-Uranium Extraction (PUREX) Plant}

The PUREX Plant is located in the 200-East Area and is a collection of buildings and facilities that was used for the processing by chemical separation of irradiated fuel elements, as part of nuclear weapons production. The primary components of the plant are the 202-A Building (main canyon building) in which fuels were reprocessed, 203-A pumphouse and tank farm, 211-A pumphouse and tank farm, 206-A Acid Fractionator Building, 291-AE Building, 293-A Building (backup facility), effluent monitoring buildings, and railroad tunnel. The plant has been deactivated (i.e., prepared for long-term, safe, unstaffed surveillance).

\section{Airborne Effluents}

The PUREX Plant is the source of one active airborne effluent stream (i.e., 291-A-1 stack). Gaseous effluents continue to be discharged during its deactivation mode. The stack has the potential to exceed 40 CFR 61, Subpart $\mathrm{H}$, criteria requiring continuous emissions measurement and air monitoring for americium-241, iodine-129, and plutonium-239/240.

\section{Liquid Effluents}

All liquid effluent streams have been eliminated. 


\section{Facility Effluent Monitoring Plan Determination}

A plan is required for the PUREX Plant because of the potential for radionuclide concentrations in the airborne effluent from the 291-A-1 stack to cause a dose to the maximally exposed individual of greater than 0.1 millirem per year EDE. The latest facility effluent monitoring plan (BHI-01246) was reissued in 1999 by Bechtel Hanford, Inc. after transition of the PUREX Plant from Fluor Hanford, Inc.

\section{Tank Farm Complex}

The tank farm complex, managed by CH2M HILL Hanford Group, Inc., is located within the 200-East and 200-West Areas. A total of 177 single-shell and double-shell tanks with transfer, receiving, and treatment facilities make up the complex. Major components evaluated for the facility effluent monitoring plan include the single- and double-shell tank farms, 204-AR unloading station, 244-CR vault, double-contained receiver tanks, and waste transfer lines. No upset scenarios.considered for the transfer lines would produce a release requiring a facility effluent monitoring plan. Chemical constituents include iron(III) hydroxide, sodium aluminate, sodium carbonate, sodium hydroxide, sodium nitrate, sodium nitrite, sodium phosphate, sodium sulfate, and various organic compounds. Radionuclides may include americium-241, cesium-137, iodine-129, plutonium-238, plutonium-239, plutonium-240, plutonium-241, strontium-90, technetium-99, uranium-235, and uranium-238.

\section{Airborne Effluents}

Eleven stacks require facility effluent monitoring plans, based on the calculated potential for each stack of greater than 0.1 millirem EDE to the maximally exposed offsite individual.

\section{Liquid Effluents}

The Tank Farm Complex has no active liquid effluents.

\section{Facility Effluent Monitoring Plan Determination}

A plan is required for the tank farm complex because of the potential for radionuclide concentrations in airborne effluents from each of several stacks to cause a dose to the maximally exposed individual of greater than 0.1 millirem per year EDE. The facility effluent monitoring plan (HNF-EP-0479-4) was updated in May 2000.

\section{Waste Receiving and Processing Facility (Module 1)}

This facility is located in the 200-West Area and is housed in the 2336-W Building just north of the Central Waste Complex. The facility is a metal building, consisting of preinsulated, prefinished metal, interlocking roof, and wall sandwich panels. The facility became operational in 1997 and receives, processes, and ships waste. The building has mechanical, electrical, heating, ventilating, and cooling rooms, as well as administrative areas. 


\section{Airborne Effluents}

A gaseous effluent monitoring/sampling system operates to collect near-isokinetic samples for compliance with 40 CFR 61, Subpart H, and with WAC 246-247. The stack has sample probes that divert a sample of the exhaust stream via transport tubing to the sampling/monitoring cabinet. The transport lines are heat traced to prevent condensation within the tubing. A record sampler inside the sampling/monitoring cabinet collects a sample for laboratory analysis. A continuous air monitor scans the sample for alpha and beta contamination that exceeds concentration limits. The stack also houses a temperature probe and a velocity probe. The flow through the systems is established and maintained by vacuum pumps and is measured by flow-measuring sensors.

\section{Liquid Effluents}

The facility is equipped with a TRUPACT-II (transuranic package transporter) loading and unloading bay with a full-length floor drain to divert melting snow and ice to the proper disposal location. The TRUPACT bay also has potable water for hosing off vehicles. The drain runs out of the east side of the facility to a sand interceptor. From the sand interceptor, the stream is discharged to a gravel drain basin. The discharge stream from the TRUPACT bay has been listed in the site inventory of miscellaneous streams. The sludge that accumulates in the drain is sampled for hazardous and radioactive constituents, and any liquid is sampled for hazardous and radioactive material during clean out.

The facility has a mechanical room that houses two compressors, an air dryer, several pumps, and a domestic water heater. The condensate that builds up in the compressor is combined with the air dryer condensate and discharged to a gravel basin on the north side of the facility. The condensate passes through an oil/water separator prior to discharge to the environment. The effluent will be sampled periodically.

\section{Facility Effluent Monitoring Plan Determination}

The estimated potential hazardous material quantities do not exceed their respective 40 CFR 302 reportable quantities on a 24-hour basis. Therefore, no federal, state, and local effluent regulations, as well as DOE Orders, require any special regulated material monitoring requirements. However, the potential EDE for radioactive constituents does exceed the continuous emission measurement criteria listed in 40 CFR 61, Subpart H. Therefore, full compliance is required, as well as a facility effluent monitoring plan (HNF-EP-0885-1).

\section{Facility}

The 324 Facility in the 300 Area primarily supported the research and development of radioactive and nonradioactive waste vitrification technologies (i.e., ceramic melters, in situ vitrification, and Hanford Waste Vitrification Program design support), biological waste remediation technologies, spent nuclear fuel studies, waste mixing and transport studies, and tritium development programs. All of the above-mentioned programs dealt with and had the potential to release hazardous and/or radioactive material. The current mission of the 324 Facility is to accomplish safe, cost-effective deactivation and clean-out, using innovative techniques that will eliminate or mitigate all building risks and result in stable conditions requiring minimal and low-cost surveillance and maintenance. The potential for discharge 
would now primarily result from 1) conduct of clean-out deactivation activities, 2) storage of radionuclides, 3) archive storage of programmatic samples, and 4) waste accumulation and storage.

\section{Airborne Effluents}

Potential radioactive airborne effluents in the 324 Facility have been characterized, and all release pathways have been verified. Stack monitors (samplers) were upgraded to meet 40 CFR 61 criteria. The primary stack (EP-324-01-S) is currently registered with the State of Washington as required by WAC 246-247. Potential nonradioactive airborne effluents have been characterized for compliance with WAC 173-401 (i.e., the air operating permit regulations).

\section{Liquid Effluents}

This facility discharges to three sewer systems (retention process sewer, process sewer, and sanitary sewer). Liquid effluent releases are either administratively or physically controlled. Most connections to the process sewer that have the potential to release regulated effluent have been plugged. Floor and sump drains have been modified with standpipes to prevent uncontrolled discharge. Selected floor drains in facility service tunnels that must remain open in the event of main service line leaks or ruptures are posted to control liquid effluent disposal. Liquid effluent lines from the facility enter the 300 Area liquid effluent system. This system is monitored before release to the environment. Note that there is also a radioactive liquid waste system as well. However, the radioactive liquid waste is not released to the environment but is transferred to the 200 Areas tank farms.

\section{Facility Effluent Monitoring Plan Determination}

An inventory-based method was used to estimate the maximum potential offsite dose if airborne releases from the facility were unmitigated. The projected unmitigated dose met the criterion of greater than 0.1 millirem per year EDE for preparing a facility effluent monitoring plan. A list of chemicals in the facility was obtained; chemical quantities were all less-than-reportable quantities; therefore, it was unnecessary to characterize the potential for emissions of nonradioactive hazardous materials. Management of the facility has been transferred from PNNL to Fluor Hanford, Inc., who updated the facility effluent monitoring plan (HNF-4222) in March 1999.

\section{Building}

This building (the Radiochemical Processing Laboratory) in the 300 Area houses radiochemistry research, radioanalytical service, radiochemical process development, and hazardous and mixed hazardous waste-treatment activities. The laboratories and specialized facilities enable work ranging from that with nonradioactive materials to that with picogram-to-kilogram quantities of fissionable materials and up to megacurie quantities of other radionuclides. The special facilities include two shielded hot cell areas that provide for process development or analytical chemistry work with highly radioactive materials and a waste-treatment facility for processing hazardous, mixed, low-level, and transuranic waste. 
Radioactive material storage and usage occur throughout the building and include a large number of isotopes. This material is in several forms, including solid, liquid, particulate solids, and gaseous. Some of these materials are also heated during testing.

\section{Airborne Effluents}

Potential radioactive airborne effluents have been characterized, and all release pathways have been verified. Stack monitors (samplers) were upgraded to meet 40 CFR 61 criteria. The primary stack (EP-325-01-S) is currently registered with the Washington State Department of Health as required by WAC 246-247. Emissions of nonradioactive volatile organic compounds and toxic air pollutants have been characterized and determined to be within applicable permits and regulatory limits (PNNL-SA32816).

\section{Liquid Effluents}

Liquid effluent release pathways are either administratively or physically controlled. Connections to the process sewer that have the potential to release regulated effluents have been plugged. The remaining drains (primarily laboratory sink and hood drains) have been posted with labels identifying the type of drain and liquid effluent disposal controls.

This building has three liquid effluent systems (i.e., radioactive liquid waste system, retention process sewer, and sanitary sewer). Because of the age of the building and the out-of-date engineering drawings, some effluent system lines were found to be labeled (and used) inappropriately during liquid effluent line verification (conducted in 1991). Modifications were completed as soon as the lines were correctly identified. The retention process sewer lines from the building enter the 300 Area liquid effluent system. The system is monitored before release to the environment. The radioactive liquid waste system is not released into the environment but is transferred to a tank system within the 325 Facility and then to the 200 Areas tank farms.

Liquid effluent monitoring instruments, including a flow-proportional liquid sampler, in-line $\mathrm{pH}$ meter, and conductivity meter, are maintained for sampling in response to potential concerns at the 300 Area Treated Effluent Disposal Facility.

\section{Facility Effluent Monitoring Plan Determination}

An inventory-based method was used to estimate the maximum potential offsite dose if airborne releases from the building were unmitigated. The projected unmitigated dose met the criterion of greater than 0.1 millirem per year EDE for preparing a facility effluent monitoring plan. A list of chemicals in the building was obtained; chemicals in greater-than-reportable quantities were identified to characterize the potential for emissions of nonradioactive hazardous materials. The facility effluent monitoring plan (PNNL-12157) was updated in March 1999.

\section{Facility}

The 327 Facility in the 300 Area provided office and laboratory space for scientific and engineering staff to conduct multidisciplinary research in the areas of post-irradiated fuels and structural materials. 
The building was designed to accommodate the use of radioactive and hazardous materials in the conduct of these research activities. The current mission of the 327 Facility is to accomplish safe, cost-effective deactivation and clean-out, using innovative techniques that will eliminate or mitigate all building risks and result in stable conditions requiring minimal and low-cost surveillance and maintenance.

\section{Airborne Effluents}

The potential radioactive airborne effluents from this facility have been characterized, and all release pathways have been verified. Stack monitors (i.e., samplers) were upgraded to meet 40 CFR 61 criteria. Two stacks (EP-327-01-S and EP-327-02-V) are currently registered with the Washington State Department of Health as required by WAC 246-247. Potential nonradioactive airborne effluents have been characterized for compliance with WAC 173-401 (i.e., the air operating permit regulations).

\section{Liquid Effluents}

This facility discharges liquid effluents to three sewer systems (i.e., retention process sewer, process sewer, and sanitary sewer). Liquid effluent releases are either administratively or physically controlled. Most connections to the process sewer that have the potential to release regulated effluent have been plugged; the remaining (primarily laboratory sink and hood drains) have been posted with labels identifying the type of drain and liquid effluent disposal instructions. Floor and sump drains have been modified with standpipes to prevent uncontrolled discharge. Select floor drains in facility service areas that must remain open in the event of main service line leaks or ruptures are also posted to control disposal of liquid effluents.

Liquid effluent lines from the facility enter the 300 Area liquid effluent system. The retention process sewer, process sewer, and sanitary sewer are monitored before release to the environment. Note that there is a radioactive liquid waste system as well. However, the radioactive liquid was not released to the environment, but transferred to the 340 Facility for disposal and is now isolated from the 340 Facility, which has been shut down.

\section{Facility Effluent Monitoring Plan Determination}

An inventory-based method was used to estimate the maximum potential offsite dose if airborne releases from the building were unmitigated. The projected unmitigated dose met the criterion of greater than 0.1 millirem per year EDE for preparing a facility effluent monitoring plan. A list of chemicals in the building was obtained; chemical quantities were less-than-reportable quantities; therefore, it was unnecessary to characterize the potential for emissions of nonradioactive hazardous materials. Management of the facility has been transferred from PNNL to Fluor Hanford, Inc., who updated the facility effluent monitoring plan (HNF-4223) in March 1999.

\section{Building}

The 331 complex in the 300 Area houses research in life sciences, materials characterization and testing, and waste management activities. The facility is designed to accommodate the use of radioactive and hazardous materials to conduct these activities. Radioactive material storage and usage occur primarily in the 331 Building with sealed sources and small quantities also in $331 \mathrm{G}$ and $331 \mathrm{H}$. 


\section{Airborne Effluents}

Potential radioactive airborne effluents have been characterized, and all release pathways have been verified. Stack monitors (samplers) were upgraded to meet 40 CFR 61 criteria. The primary stack (EP-331-01-V) is currently registered with the Washington State Department of Health as required by WAC 246-247. Emissions of nonradioactive volatile organic compounds and toxic air pollutants have been characterized and determined to be within applicable permit and regulatory limits (PNNL-SA32816).

\section{Liquid Effluents}

Liquid effluent release pathways in the 331 complex are either administratively or physically controlled. Connections such as floor drains in the laboratory spaces that have the potential for inadvertent release of chemicals or radioactive material to process sewers have been plugged. The remaining drains have been posted with labels stating the type of drain and liquid effluent disposal controls.

The 331 complex has three sewer systems: the process sewer, the sanitary sewer, and the aquaculture system. Process sewer effluent lines from the 331 Facility enter into the 300 Area liquid effluent system. The process sewer is monitored prior to discharge to the Columbia River via the 300 Area TEDF. The 300 Area sanitary sewer is monitored prior to discharge to the city of Richland publicly owned treatment works. The aquaculture system is monitored by PNNL prior to discharge to the Columbia River.

\section{Facility Effluent Monitoring Plan Determination}

An inventory-based method was used to estimate the maximum potential offsite dose if airborne releases from the building were unmitigated. The projected unmitigated dose met the criterion of greater than 0.1 millirem per year EDE for preparing a facility effluent monitoring plan. A list of chemicals in the building was obtained; chemicals in greater-than-reportable quantities were identified to characterize the potential for emissions of nonradioactive hazardous materials. The facility effluent monitoring plan (PNNL-12158) was updated in March 1999.

\section{Complex}

The 340 complex is located in the 300 Area near the Columbia River. Buildings 324, 325, 326, 327, and 329 formerly discharged waste directly into the 340 complex. Two waste streams are managed by the 340 complex, the now inactive radioactive liquid waste system, and the retention process sewer. Inventories of both radionuclides and hazardous materials are limited primarily to residual heels in the radioactive liquid waste sewer and are itemized in the facility effluent monitoring plan.

\section{Airborne Effluents}

The radioactive liquid waste system, which has real-time monitors, has the potential to release gaseous/particulate radioactive contaminants to the atmosphere. The system had historically received waste from several sources and stores the waste in one of the two belowground 56,775-liter 
(15,000-gallon) storage tanks. The stored waste was then transported quarterly to the 204-AR unloading facility in the 200-East Area for long-term storage and/or disposal. Until residual inventories and contamination can be removed or fixed, high-efficiency particulate air filtered exhaust systems will remain active.

\section{Liquid Effluents}

The retention process sewer receives potentially radioactive liquid effluents. The liquid effluents from this sewer are monitored for gross beta and gamma radiation with real-time monitoring instruments, and released to the 300 Area TEDF following alpha counting on a composite/grab sample.

\section{Facility Effluent Monitoring Plan Determination}

A facility effluent monitoring plan is required for the 340 complex because of the potential for radionuclides in airborne emissions stacks to cause a dose to the maximally exposed individual of greater than 0.1 millirem per year EDE. The plan (HNF-EP-0469-2) was issued in 1997.

\section{Facility}

This facility (the Environmental Sciences Laboratory) provides office and laboratory space for scientific and engineering staff who conduct multidisciplinary research in the areas of materials characterization and testing and waste management. The facility is designed to accommodate the use of radioactive and hazardous materials in the conduct of these activities.

Radioactive material storage and usage occur throughout the facility and include a large number of isotopes. This material is in several forms, including solid, liquid, and dispersible particulate. The facility is in the process of being vacated for shutdown, but currently maintains the capability for work with radioactive material such that it still has a major emission point.

\section{Airborne Effluents}

Potential radioactive airborne effluents in the 3720 Facility have been characterized, and all release pathways have been verified. Stack monitors (samplers) were upgraded to meet 40 CFR 61 criteria. The primary stack at the facility (EP-3720-01-S) is currently registered with the Washington State Department of Health as required by WAC 246-247. Potential nonradioactive airborne effluents were characterized for compliance with WAC $173-401$ (i.e., the air operating permit regulations), and the 3720 Facility was determined to be an "insignificant emission unit."

\section{Liquid Ėfluents}

This facility discharges to the process sewer and the sanitary sewer. Liquid effluent releases are either administratively or physically controlled. Most connections to the process sewer that had the potential to release regulated effluent have been plugged; the remaining (primarily laboratory sink and hood drains) have been posted with labels identifying the type of drain and liquid effluent-disposal controls. 
Process sewer effluent lines from the facility enter the 300 Area TEDF. Sanitary sewer effluent lines from the facility join with the sanitary sewer lines from other 300 Area facilities and enter the city of Richland's publicly owned treatment works. Liquid effluent monitoring instruments, including a flowproportional liquid sampler, in-line $\mathrm{pH}$ meter, and conductivity meter, are maintained at the process sewer discharge for sampling in response to potential concerns at the 300-Area TEDF.

\section{Facility Effluent Monitoring Plan Determination}

An inventory-based method was used to estimate the maximum potential offsite dose if airborne releases from the building were unmitigated. The projected unmitigated dose met the criterion of greater than 0.1 millirem per year EDE for preparing a-facility effluent monitoring plan. A list of chemicals in the facility was obtained; chemicals in greater-than-reportable quantities were identified to characterize the potential for emissions of nonradioactive hazardous materials. The plan (PNNL-12159) was updated in March 1999.

\section{Pacific Northwest National Laboratory Balance-of-Plant}

PNNL operates a number of research and development facilities for DOE on the Hanford Site. Three of the facilities, the 325,331 , and 3720 Buildings, are considered major emission points for radionuclide air sampling and, thus, individual facility effluent monitoring plans have been developed for them. Because no definition of "significant" is provided in DOE Order 5400.1 or the accompanying regulatory guide DOE/EH-0173T, the Balance-of-Plant facility effluent monitoring plan was developed to describe monitoring requirements in the DOE-owned facilities operated by PNNL that do not have individual facility effluent monitoring plans. The remainder of the DOE-owned facilities operated by PNNL are referred to as Balance-of-Plant facilities.

Activities in the Balance-of-Plant facilities range from administrative to laboratory and pilot-scale research and development. Research and development includes both radioactive and chemical waste characterization, fluid dynamics research, mechanical property testing, dosimetry research, and molecular sciences. The mission and activities for individual buildings are described in the facility effluent monitoring plan.

\section{Airborne Effluents}

Potential radioactive airborne emissions in the Balance-of-Plant facilities are estimated annually using a building inventory-based approach. The methods used are derived from 40 CFR 61, Appendix D. Sampling at individual Balance-of-Plant facilities is based on the potential-to-emit assessment. Some of these facilities are considered minor emission points and, thus, are sampled routinely, but not continuously, to confirm the low-emission potential. Sampling systems are located downstream of control technologies and just prior to discharge to the atmosphere.

The need for monitoring airborne emissions of hazardous chemicals is established in the Hanford Site Air Operating Permit and in Notices of Construction. Based on the current potential-to-emit, the permit does not contain general monitoring requirements for Balance-of-Plant facilities. However, the 
permit identifies monitoring requirements for specific projects and buildings. Needs for future monitoring will be established by future permits issued pursuant to the applicable state and federal regulations.

\section{Liquid Effluents}

A number of liquid effluent discharge systems serve the Balance-of-Plant facilities: sanitary sewer, process sewer, and retention process sewer. None of these systems discharge to the environment; they all either discharge to treatment plants or to long-term storage. Routine compliance sampling of liquid effluents is only required at the Environmental Molecular Sciences Laboratory. Liquid effluents from other Balance-of-Plant facilities may be sampled or monitored to characterize facility effluents or to investigate discharges of concern. Liquid effluent characterization data are summarized in the facility effluent monitoring plan.

\section{Facility Effluent Monitoring Plan Determination}

Effluent sampling and monitoring for the Balance-of-Plant facilities depends on the inventories, activities, and environmental permits in place for each facility. An inventory-based method was used to estimate the maximum potential offsite dose if airborne releases from the building were unmitigated. The projected unmitigated dose for these facilities did not meet the criterion of greater than 0.1 millirem per year EDE for preparing a facility effluent monitoring plan. However, some facilities had a chemical inventory with chemicals in greater-than-reportable quantities. The plan (PNNL-12160) was approved in March 1999.

\section{References}

(Draft) 10 CFR 834, Code of Federal Regulations, Title 10, Part 834. Radiation Protection of the Public and the Environment: Proposed Rule. 58 FR 56:16268-16322, March 25, 1993.

40 CFR 61, Code of Federal Regulations, Title 40, Part 61, Subpart H. National Emission Standards for Emissions of Radionuclides Other Than Radon From Department of Energy Facilities.

40 CFR 122, Code of Federal Regulations, Title 40, Part 122. EPA Administered Permit Programs: The National Pollutant Discharge Elimination System.

40 CFR 302.4, Code of Federal Regulations, Title 40, Part 302. Designation, Reportable Quantities, and Notification.

ASME (The American Society of Mechanical Engineers) NQA-1-1989 Edition. 1989. Quality Assurance Program Requirements for Nuclear Facilities, An American National Standard. New York.

BHI-01246, Rev. 0. 1999. Facility Effluent Monitoring Plan for the Plutonium-Uranium Extraction Facility. Bechtel Hanford, Inc., Richland, Washington.

BHI-01371, Rev. 0. 2000. Facility Effluent Monitoring Plan for B Plant. Bechtel Hanford, Inc., Richland, Washington. 
Clean Air Act Amendments of 1990, Public Law 101-549, 42 USC 7401-7671Q.

DOE/EH-0173T. 1991. Environmental Regulatory Guide for Radiological Effluent Monitoring and Environmental Surveillance. Assistant Secretary for Environment, Safety and Health, U.S. Department of Energy, Washington, D.C.

DOE Order 5400.1. "General Environmental Protection Program."

DOE Order 5400.5. "Radiation Protection of the Public and the Environment."

HNF-1974. 1998. Hanford Site Radionuclide National Emission Standards for Hazardous Air Pollutants Stack Source Assessment. W. E. Davis. Fluor Daniel Hanford, Inc., Richland, Washington.

HNF-3602, Vol. 1. 1999. Volume 1: Calculating Potential to Emit Releases and Doses for FEMPs and NOCs. Fluor Daniel Hanford, Inc., Richland, Washington.

HNF-4222. 1999. Facility Monitoring Plan for the 324 Facility. Fluor Daniel Hanford, Inc., Richland, Washington.

HNF-4223. 1999. Facility Effluent Monitoring Plan for the 327 Facility. Fluor Daniel Hanford, Inc., Richland, Washington.

HNF-EP-0469-2. 1997. Facility Effluent Monitoring Plan for the 340 Waste Handling Facility. Waste Management Federal Services of Hanford, Inc., Richland, Washington.

HNF-EP-0476, Rev. 2. 2000. Facility Effluent Monitoring Plan for the Plutonium Finishing Plant. Fluor Hanford, Inc., Richland, Washington.

HNF-EP-0479-4. 2000. Facility Effluent Monitoring Plan for the Tank Farm Facility. CH2M HILL Hanford Group, Inc., Richland, Washington.

HNF-EP-0497, Rev. 3. 2000. Facility Effluent Monitoring Plan for the Spent Nuclear Project. Fluor Hanford, Inc., Richland, Washington.

HNF-EP-0528-3. 1998. NESHAP Quality Assurance Project Plan for Radioactive Air Emissions Data. Fluor Daniel Hanford, Inc., Richland, Washington.

HNF-EP-0885-1. 2000. Facility Effluent Monitoring Plan for the Waste Receiving and Processing Facility. Fluor Hanford, Inc., Richland, Washington.

HNF-PRO-3679. 2000. Effluent and Environmental Monitoring. Fluor Hanford, Inc., Richland, Washington. 
PNNL-10855, Rev. 1. 1999. Assessment of Unabated Facility Emission Potentials for Evaluating Airborne Radionuclide Monitoring Requirements at Pacific Northwest National Laboratory - 1999. M. Y. Ballinger, K. D. Shields, M. J. Sula, and D. L. Edwards, Pacific Northwest National Laboratory, Richland, Washington.

PNNL-11552. 1997. Characterization and Monitoring of 300 Area Facility Liquid Waste Streams During 1994 and 1995. C. J. Thompson, M. Y. Ballinger, E. G. Damberg, and R. G. Riley, Pacific Northwest National Laboratory, Richland, Washington.

PNNL-12157. 1999. Facility Effluent Monitoring Plan for the 325 Radiochemical Processing Laboratory. Pacific Northwest National Laboratory, Richland, Washington.

PNNL-12158. 1999. Facility Effluent Monitoring Plan for the 331 Complex. Pacific Northwest National Laboratory, Richland, Washington.

PNNL-12159. 1999. Facility Effluent Monitoring Plan for the 3720 Building. Pacific Northwest National Laboratory, Richland, Washington.

PNNL-12160. 1999. Facility Effluent Monitoring Plan for Pacific Northwest National Laboratory Balance-of-Plant Facilities. Pacific Northwest National Laboratory, Richland, Washington.

PNNL-SA-32816. 2000. Chemical Air Emissions from an R\&D Laboratory. R. K. Woodruff, C. J. Benar, and M. J. McCarthy, Air and Waste Management Association's 2000 Annual Conference and Exhibition Proceedings. Air \& Waste Management Association, Pittsburgh, Pennsylvania.

QAMS-005/80. 1983. Interim Guidelines and Specifications for Preparation of Quality Assurance Project Plans. Office of Exploratory Research, U.S. Environmental Protection Agency, Washington, D.C.

Resource Conservation and Recovery Act of 1976, as amended, Public Law 94-580, 90 Stat. 2795, 42 USC 6901 et seq.

WAC 173-200, Washington Administrative Code. Water Quality Standards for Ground Waters of the State of Washington. Olympia, Washington.

WAC 173-401, Washington Administrative Code. Operating Permit Regulation. Olympia, Washington.

WAC 173-480, Washington Administrative Code. Ambient Air Quality Standards and Emission Limits for Radionuclides. Olympia, Washington.

WAC 246-247, Washington Administrative Code. Radiation Protection - Air Emissions. Olympia, Washington.

WHC-EP-0438-1. 1992. A Guide for Preparing Hanford Site Facility Monitoring Plans. Westinghouse Hanford Company, Richland, Washington.

WHC-EP-0446-2. 1994. Quality Assurance Project Plan for Facility Effluent Monitoring Plan Activities. Westinghouse Hanford Company, Richland, Washington. 


\section{Hanford Site Environmental Monitoring Plan}

\section{Section II.B. Near-Facility Environmental Monitoring}

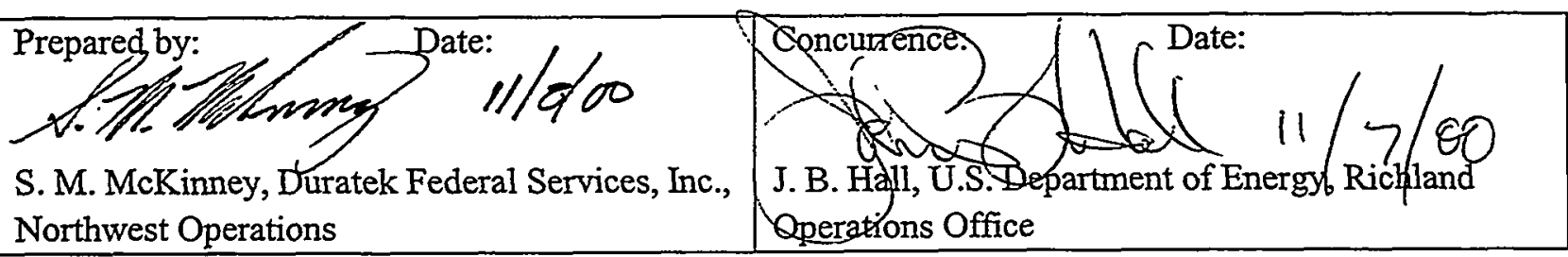




\section{Introduction}

Near-facility environmental monitoring is an important element of the Effluent and Environmental Monitoring Program managed by Fluor Hanford and is performed by Waste Management Federal

Services, Inc., in accordance with U.S. Department of Energy (DOE) Order 5400.1 and quality assurance criteria specified in HNF-EP-0538-5. Hanford Site facilities and operations with the potential for significant environmental impact are sampled during preoperational environmental monitoring to establish an environmental baseline upon which to design the routine near-facility environmental monitoring to be performed.

\section{Preoperational Environmental Survey}

A preoperational environmental survey is required by Chapter IV, Paragraph 3 of DOE Order 5400.1:

"An environmental study shall be conducted prior to startup of a site, facility, or process which has the potential for significant adverse environmental impact. The preoperational study should begin not less than one year, and preferably two years before startup to evaluate seasonal changes. The study shall serve to: characterize existing physical, chemical, and biological conditions that could be affected; establish background levels of radioactive and chemical components; characterize pertinent environmental and ecologic parameters; and identify potential pathways for human exposure and environmental impact as a basis for determining the nature and extent of the subsequent routine operational and emergency effluent monitoring and environmental surveillance programs. Where time and circumstance do not allow for completion of preoperational monitoring prior to startup, it shall be conducted concurrent with work on the new site, facility, or process. The preoperational study shall be consistent with NEPA compliance activities. Where appropriate, activities and documentation conducted for NEPA compliance may substitute for compliance with this requirement."

General guidelines for conducting a preoperational environmental survey can be found in DOE/ EH-0173T and DOE/LLW-13Tg. Specific references for conducting the preoperational environmental survey can also be found in HNF-PRO-3679 and WMTS-OEM-001.

\section{User Identification}

There are five primary users of a preoperational environmental survey:

1) the planning and construction organization (to demonstrate compliance with DOE Order 5400.1)

2) the facility operating organization (to show that containment systems for stored chemicals and waste remain adequate in compliance with DOE Order 5400.1) 
3) the program staff (to provide adequate data for determining the need to modify the existing nearfacility monitoring objectives and to determine effluent trends and environmental conditions)

4) the Surface Environmental Surveillance Project (managed by Pacific Northwest National Laboratory) to adjust monitoring locations if needed

5) legal counsel to provide input to plaintiff requests and demonstrate regulatory compliance.

\section{Survey Design}

A preoperational environmental survey is designed to monitor the media specified in DOE/ EH-0173T and DOE/LLW-13Tg. To assist in designing this survey, existing documents (e.g., unplanned release reports, occurrence reports, operational and site environmental reports, historical photographs, environmental impact statements, and preliminary safety analysis reports) are reviewed.

Before initiating preoperational sampling of any new or modified facility or process, a sampling and analysis plan is prepared and issued. The sampling and analysis plan contains a project description, media to be sampled, analyses to be performed, and sampling design rationale.

Once preoperational monitoring is completed and analytical data are available, the results are included in a final preoperational environmental monitoring report (e.g., WHC-SD-W058-RPT-001, WHC-SD-WM-TI-778, HNF-4401, HNF-6150).

\section{Routine Near-Facility Environmental Monitoring}

Facility-specific environmental monitoring is provided for the protection of the environment adjacent to nuclear facilities and waste storage, treatment, and disposal sites in compliance with applicable federal, state, and local environmental regulations and requirements.

The objectives of this monitoring are to evaluate the following:

- compliance with federal, state, and local environmental radiation protection requirements and guides

- performance of radioactive waste-confinement systems

- concentration trends of radioactive materials in the environment at and adjacent to nuclear facilities, waste disposal sites, and remedial action activities. 
Specifically, near-facility environmental monitoring entails the following functions:

- monitoring all inactive, existing, and new low-level waste-disposal sites to assess both radiological and nonradiological hazards (DOE Order M 435.1-1)

- determining the effectiveness of treatments and controls used to reduce effluents and emissions (DOE/EH-0173T)

- detecting and quantifying unplanned releases (DOE/EH-0173T, 40 CFR 302, WAC 173-303-145, DOE Orders O 232.1A and 5484.1)

- monitoring fugitive emissions (i.e., diffuse sources) from contaminated areas for compliance with national emission standards for hazardous air pollutants (40 CFR 61, DOE/EH-0173T), toxic air emissions (40 CFR 265, Subparts AA and B13), state operating permits ( 40 CFR 70), and source registration (WAC 246-247)

- monitoring all surplus facilities before decontaminating or decommissioning (DOE Order M 435.1-1)

- monitoring new and existing sites, processes, and facilities to determine potential environmental impacts and releases of contaminants (DOE Order 5484.1, DOE/EH-0173T)

- monitoring and assessing environmental radioactive contamination and potential exposure to employees and the public (DOE Orders 5400.1 and 5400.5).

The primary justifications for near-facility environmental monitoring include the following:

- provide a level of assurance that the effluent and contamination controls for the various facilities and waste sites are effective

- monitor a diversity of operations, activities, and programs managed by several different organizations (accordingly, direction and integration are needed to ensure consistency, technical quality, and cost effectiveness)

- provide data to ensure safe site access.

Near-facility environmental monitoring staff are responsible for planning, directing, and executing the effective, technically sound monitoring of all media (except groundwater) and for ensuring that the regulations and requirements are satisfied. This responsibility includes establishing the basis and scope, developing the sample and survey schedules, and ensuring that the schedules and procedures are followed by the performing organizations. The staff serve as the primary contact within and outside of Hanford Site contractors in technical matters pertaining to near-facility environmental monitoring and represent Hanford Site contractors at meetings with environmental regulators regarding this type of work.

Data obtained as a result of near-facility environmental monitoring are used to identify areas of noncompliance with regard to loss of contamination control. Radiological problem reports, occurrence 
reports, and compliance assessment reports are the formal mechanisms for documenting instances of noncompliance. Formal tracking of noncompliance is also performed. Compliance schedules by the noncompliant organization are then closely tracked to determine their effectiveness. These activities perform the critical function of formally identifying areas of concern regarding unacceptable environmental conditions.

A list of federal, state, and Hanford Site documents regulating activities is given in Table II.B-1.

\section{User Identification}

There are five primary users of near-facility environmental monitoring:

1) the planning and construction organization (to demonstrate compliance with DOE Order 5400.1)

2) the facility operating contractor (to show that containment systems for stored chemicals and wastes remain adequate in compliance with DOE Order 5400.1)

3) the program staff (to provide adequate data for determining the need to modify the existing nearfacility monitoring objectives and to determine effluent trends and environmental conditions)

4) the Surface Environmental Surveillance Project (managed by Pacific Northwest National Laboratory) to adjust monitoring locations if needed

5) legal counsel to provide input to requests and demonstrate regulatory compliance.

\section{Review}

The scope of near-facility environmental monitoring is reviewed by management and staff at least annually to ensure that the work complies with regulations, that appropriate effluents are being monitored, and that the monitoring locations are positioned to best determine and quantify potential releases.

\section{Design}

\section{Sampling Locations, Frequency, Media Sampled, and Parameters Monitored}

Media near active/inactive facilities to be sampled include ambient air particulates, soil, surface water, sediment, and biota. Parameters routinely monitored include, as appropriate, radionuclide concentrations, radiation exposure levels, radiation dose, hazardous constituent concentrations, $\mathrm{pH}$, and water temperatures. Sample types, collection and measurement frequencies, and analytes and parameters monitored are given in Table II.B-2. 
Table I.B-1. Governing Documents

\begin{tabular}{l} 
Document Number \\
\hline DOE Order 5400.1 \\
Chapter III \\
Chapter IV \\
DOE Order 5400.5 \\
Chapter 1 \\
Paragraph 8 \\
DOE Order M 435.1-1 \\
DOE Order 5484.1
\end{tabular}

DOE Order O 232.1A

DOE/LIW-13Tg

DOE/EH-0173T

40 CFR 61

40 CFR 70

40 CFR 264

40 CFR 265

40 CFR 302

WAC 173-303-145

WAC $173-400$

WAC 246-247

DOE/RL-91-50 (latest revision)

HNF-PRO-3679

HNF-PRO-454

HNF-PRO-455.

WMTS-OEM-001

HNF-EP-0538-5
Title

General Environmental Protection Program

Environmental Protection Program Plans

Environmental Monitoring Requirements

Radiation Protection of the Public and the Environment

General

Environmental Monitoring and Surveillance

Radioactive Waste

Environmental Protection, Safety, and Health Protection Information Reporting Requirements

Occurrence Reporting and Processing of Operations Information

Low-Level Waste Management Handbook Series, Environmental Monitoring for Low-Level Waste Disposal Sites

Environmental Regulatory Guide for Radiological Effluent Monitoring and Environmental Surveillance

National Emission Standards for Hazardous Air Pollutants

State Operating Permit Programs

Final Status Standards for Owners and Operators of Hazardous Waste Treatment, Storage, and Disposal Facilities

Interim Status Standards for Owners and Operators of Hazardous Waste Treatment, Storage, and Disposal Facilities

Designation, Reportable Quantities, and Notification

Dangerous Waste Regulations (Spills and Discharges into the Environment)

General Regulations for Air Pollution Sources

Radiation Protection - Air Emissions

Environmental Monitoring Plan, U.S. Department of Energy, Richland Operations Office

Effluent and Environmental Monitoring

Inactive Waste Sites

Solid Waste Management

Operational Environmental Monitoring

Near-Facility Environmental Monitoring Program Quality Assurance Project Plan 
Table II.B-2. Near-Field Sampling Media, Frequency, Analytes, and Parameters

\begin{tabular}{|c|c|c|}
\hline Sample Types & $\begin{array}{c}\text { Collection or } \\
\text { Measurement Frequency }\end{array}$ & Analytes/Parameters Monitored \\
\hline $\mathrm{Air}$ & $\begin{array}{l}\text { Biweekly } \\
\text { Semiạnnual }\end{array}$ & $\begin{array}{l}\text { Gross alpha and beta } \\
\text { Strontium, plutonium, uranium, gamma }\end{array}$ \\
\hline Soil & Annual & Strontium, plutonium, uranium, gamma \\
\hline Vegetation & Annual & Strontium, plutonium, uranium, gamma \\
\hline Animals & Annual & Strontium, plutonium, uranium, gamma \\
\hline Thermoluminescent dosimeter & Quarterly & External radiation dose \\
\hline Survey point & Annual & External radiation dose \\
\hline Surface water & $\begin{array}{l}\text { Monthly } \\
\text { Annual }\end{array}$ & $\begin{array}{l}\mathrm{pH} \\
\text { Gross alpha and beta, strontium, } \\
\text { gamma, nitrates }\end{array}$ \\
\hline $\begin{array}{l}\text { Columbia River shoreline } \\
\text { seepage }\end{array}$ & Annual & Strontium, gamma, tritium \\
\hline Sediment & Annual & Strontium, plutonium, uranium, gamma \\
\hline Aquatic vegetation & Annual & Strontium, plutonium, uranium, gamma \\
\hline
\end{tabular}

\section{Monitoring Locations}

Information regarding specific sampling locations can be found in WMTS-OEM-001. The criteria for establishing monitoring locations for each of the media in Table II.B-2 are as follows:

- air - downwind and within a few meters of a source. Unless documented site-specific evidence exists to justify otherwise, the sample(s) will be collected in a location free from unusual localized effects or other conditions (i.e., near a large building, vehicular traffic, trees) that could result in artificially high or low concentrations.

- soil and vegetation - on or near sites and/or facilities with the potential for biological intrusion

- animals - on or near sites and/or facilities with the potential for biological intrusion. Animals are sampled opportunistically.

- surface water, sediment, and aquatic vegetation - at ponds or ditches used for disposal of, or potentially impacted by, liquid effluents from operating facilities

- external dose rate - at or near facilities that may cause elevated dose rates, including active/inactive sites, access areas, waste-handling facilities, effluent-discharge points, and other suspected pathways for radiation exposure 
- radiation surveys - at inactive waste sites; outdoor radiological control areas; tank farm perimeters and associated diversion boxes, lift stations, and vent stations; perimeters of active or uncovered waste sites (e.g., retention basins, ponds, solid waste burial grounds, ditches); and road and rail surfaces.

\section{Sampling Frequency}

A routine near-facility environmental monitoring schedule is developed, reviewed, and approved by Waste Management Federal Services, Inc., Fluor Hanford, Inc., and Bechtel Hanford, Inc. The survey frequencies for particular sites are based on site history, radiological conditions, and general maintenance. All sites are surveyed at least once each year. Special surveys may be conducted at irregular frequencies if conditions warrant (e.g., growth of deep-rooted vegetation is noted at a waste site). Sampling frequencies are shown in Table II.B-2.

\section{Sampling and Measurement Methods}

Sampling methods are reviewed to determine equipment efficiency and to comply with current federal (U.S. Environmental Protection Agency) and industry (American National Standards Institute, American Society for Testing and Materials) standards. The following sampling methods are routinely used for near-facility environmental monitoring:

- ambient air - air sampling stations collect samples at a height of 2 meters above ground level and use a vacuum pump to pull air through a 47 millimeter glass fiber filter at a nominal flow rate of 2 cubic feet per minute. A timer and flow-rate meter are used to determine sample time and flow rate, respectively. Filters are collected biweekly to prevent dust loading and impaired flows on the sample filter.

- soil - soil sampling equipment may be one of three types: 1) a spade, 2) a core sampler (split spoon) for special soil sampling, or 3) a plug ("cookie cutter") sampler for routine samples. All equipment is easily decontaminated or is disposable. Samples are placed in a sealable plastic bag or other suitable container and, if necessary, into an appropriate container for shipment.

- vegetation - vegetation sampling equipment consists of pruning shears, loppers, saws, a core drill, or a machete. Samples are cut to length, placed in a plastic bag, and, if necessary, into an appropriate container for shipment.

- animals - animal samples are usually collected as a result of pest control activities. The animals are checked for radioactive contamination by radiation control staff; those animals found to be contaminated may be kept for analysis. The samples are put in a plastic bag and, if necessary, into an appropriate container for shipment.

- surface water - surface water collection equipment consists of a clean cup (approximately 1 liter) attached to the end of a sampling pole. A sample is taken at a designated sampling location by dipping the sampling cup into the surface water (being careful not to disturb the sediments). The sample is then poured into a larger sample container, and the process repeated until the sample 
container is full. One additional full cup of water is then taken from the surface water, and a field $\mathrm{pH}$ reading is taken. This water is then returned to its source.

- sediment - sediment samples are collected using two methods:

- a soil core sampler equipped with a sample liner. The core sampler is forced into the sediment to a depth of 30 centimeters. The liner is withdrawn from the sampler, and the retained sediment is placed into a watertight plastic jar, sealed, and labeled appropriately for delivery to the designated laboratory for analyses.

- a spade and "cookie cutter"/spatula-type sampler. The sample is collected by skimming an approximate 2.54-centimeter-deep.portion of sediment into the spade and removing it carefully from the water. The cookie cutter is forced into the sediment. Excess sediment is removed by scraping it away with the spatula. The spatula is then carefully placed under the cookie cutter, trapping the sample. The sample is placed in a watertight plastic jar, sealed, and labeled appropriately for delivery to the designated laboratory for analyses.

- aquatic vegetation - aquatic vegetation samples are collected using various tools (e.g., shears, pruners, loppers). Vegetation is collected either directly from the water source or bank in 500-gram samples and placed in a plastic bag. The sample is double bagged and labeled appropriately for delivery to the designated laboratory for analyses.

- external dose rates - ambient dose rates are taken by two methods: Harshaw 8807 environmental thermoluminescent dosimeters (TLDs) and micro-rem meters. The TLDs consist of two lithium fluoride (TLD-700) and two calcium fluoride dysprosium (TLD-200) chips sealed in a plastic holder supplied by Pacific Northwest National Laboratory. Three TLDs are placed at each sampling location on a post at 1 meter above the ground. A Bicron micro-rem meter with a tissue equivalent organic scintillator is used to measure relative dose rates.

- radiation surveys - radiation surveys include road surfaces, cribs, stabilized burial grounds, covered ponds and ditches, tank farm perimeters, active burial ground perimeters, unplanned release sites, and other radiation areas.

- Road surveys are performed with a mobile surface contamination monitor or a vehicle equipped with sodium iodide detectors or plastic scintillators. Railroad surveys were discontinued in 1999 as the railroads are no longer in use. The detector height is adjustable in all cases, and the average survey height is 0.3 meter. When activity is detected, the vehicle is stopped and a thorough survey is made with an Eberline Model BNW-1 portable survey instrument equipped with a $\mathrm{P}-11$ probe to identify the extent of the contamination.

- Surveys at waste sites and other radiation areas may be conducted with vehicles equipped with radiation detection instruments or with hand-held field instruments. Wherever possible, smear surveys are made on the surface of exposed equipment within a radiation area. Vegetation, animal burrows, and animal feces are also monitored to detect biological transport. Detailed survey practices and procedures are described in WMTS-OEM-001, HNF-5173, and HNF-IP-0718. 


\section{Parameters Monitored}

The parameters to be monitored for each medium vary and may include the following:

- ambient air - isotopic or total gamma, gross alpha and beta, strontium, plutonium, and uranium at selected locations

- soil - isotopic or total gamma, strontium, plutonium, and uranium

- vegetation - isotopic or total gamma, strontium, plutonium, and uranium

- animals - isotopic or total gamma, strontium, plutonium, and uranium

- surface water, sediment, and aquatic vegetation - isotopic or total gamma, strontium, tritium, plutonium, uranium, nitrates, and $\mathrm{pH}$

- external dose rate - measured in the area where samples are taken to identify any increasing or decreasing trends in radiation that may affect the environment, the workers, or the public

- radiation surveys - performed to measure the surface and background radiation in the area in which the measurement is taken.

Samples are typically analyzed for the constituents listed in facility effluent monitoring plans for the facility of concern (see Section II.A). Best professional judgment is used to locate initial sampling sites to monitor the near-facility environment.

\section{Quality Assurance and Quality Control}

\section{Quality Assurance}

Quality assurance may be defined as the actions necessary to ensure the accuracy of a program. The near-facility environmental monitoring quality assurance program consists of procedures and guides to demonstrate that environmental monitoring techniques and analyses are performed within established limits of acceptance. This is documented in the Near-Facility Environmental Monitoring QA Project Plan, HNF-EP-0538-5.

Written operating procedures are an integral part of near-facility environmental monitoring quality assurance. Procedures for field operations are provided in an internal manual, Operational Environmental Monitoring, WMTS-OEM-001. The following briefly describes the essential components of the near-facility environmental monitoring quality assurance program. 


\section{Documentation}

Record keeping is a vital part of any environmental monitoring program. Maintenance of environmental data is important from a quality assurance standpoint, from a regulatory standpoint, and for trend analyses and optimization of environmental monitoring procedures. Each phase of near-facility environmental monitoring is documented. This documentation includes environmental sample logbooks, quarterly reports, annual reports, and occurrence reports.

\section{Sample Replication}

Replicate sampling and subsequent analyses are the primary means of assessing sample variability. Duplicate samples of air, water, soil, sediment, and vegetation are collected.

\section{Data Analysis}

Environmental data are reviewed to determine compliance with applicable federal and company guides. The data are analyzed both graphically and by standard statistical tests to determine trends and impacts on the environment. Newly acquired data are compared with historical data and natural background levels. Routine environmental data are stored on both magnetic media (i.e., in a computer environment) and hard-copy printouts.

\section{Analytical Procedures}

Three laboratories provided analytical support to the near-facility environmental monitoring: Pacific Northwest National Laboratory; the Waste Sampling and Characterization Facility; and the 222-S Analytical Laboratory. Samples are analyzed in accordance with prescribed procedures and quality control guides that meet the requirements of the American National Standards Institute (ANSI 1975), the Environmental Measurements Laboratory (EML 1972), the American Society for Testing and Materials (ASTM 1976), the American Public Health Association (APHA 1980), and the U.S. Environmental Protection Agency (EPA 1979).

\section{References}

40 CFR 61, Code of Federal Regulations, Title 40, Part 61. National Emission Standards for Hazardous Air Pollutants.

40 CFR 70, Code of Federal Regulations, Title 40, Part 70. State Operating Permit Programs.

40 CFR 264, Code of Federal Regulations, Title 40, Part 264. Final Status Standards for Owners and Operators of Hazardous Waste Treatment, Storage, and Disposal Facilities.

40 CFR 265, Code of Federal Regulations, Title 40, Part 265. Interim Status Standards for Owners and Operators of Hazardous Waste Treatment, Storage, and Disposal Facilities. 
40 CFR 302, Code of Federal Regulations, Title 40, Part 302. Designation, Reportable Quantities, and Notification.

ANSI. 1975. Performance, Testing, and Procedural Specifications for Thermoluminescence Dosimetry: Environmental Application. ANSI-N545-1975, American National Standards Institute, New York, New York.

APHA. 1980. Standard Methods for the Examination of Water and Waste Water. Fifteenth Edition, American Public Health Association, Washington, D.C.

ASTM. 1976. 1976 Annual Book of ASTM Standards, Water. Part 31, American Society for Testing and Materials, Philadelphia, Pennsylvania.

DOE/EH-0173T. 1991. Environmental Regulatory Guide for Radiological Effluent Monitoring and Environmental Surveillance. Assistant Secretary for Environment, Safety and Health, U.S. Department of Energy, Washington, D.C.

DOE/LLW-13Tg, Rev. 2. 1990. Low Level Waste Management Handbook Series, Environmental Monitoring for Low Level Waste Disposal Sites. U.S. Department of Energy, Washington, D.C.

DOE Order 5400.1. "General Environmental Protection Program.”

DOE Order 5400.5. "Radiation Protection of the Public and the Environment."

DOE Order 5484.1. "Environmental Protection, Safety, and Health Protection Information Reporting Requirements."

DOE Order M 435.1-1. "Radioactive Waste Management."

DOE Order O 232.1A. "Occurrence Reporting and Processing of Operations Information."

DOE/RL-91-50, Rev. 1. 1994. Environmental Monitoring Plan, United States Department of Energy, Richland Operations Office. U.S. Department of Energy, Richland Operations Office, Richland, Washington.

EML. 1972. HASL-300 Procedures. Environmental Measurements Laboratory, New York, New York.

EPA. 1979. EPA Methods for Chemical Analysis of Water and Wastes. EPA 600/4-79-020, Environmental Monitoring and Support Laboratory, U.S. Environmental Protection Agency, Cincinnati, Ohio.

HNF-4401. 1999. Preoperational Environmental Survey of the Project W-314 Pipeline. R. M. Mitchell, Waste Management Federal Services, Inc., Richland, Washington.

HNF-5173. 2000. PHMC Radiation Control Manual. Fluor Hanford, Inc., Richland, Washington. 
HNF-6150. 2000. Preoperational Environmental Survey of the Spent Nuclear Fuel Project Facilities. R. M. Mitchell, B. M. Markes, C. J. Perkins, L. M. Hay, and A. R. Johnson, Waste Management Federal Services, Inc., Richland, Washington.

HNF-EP-0538-5. 1999. Near-Facility Environmental Monitoring Program Quality Assurance Project Plan. S. M. McKinney, Waste Management Federal Services, Inc., Richland, Washington.

HNF-IP-0718. 1997. Health Physics Procedures. Fluor Daniel Hanford, Inc., Richland, Washington.

HNF-PRO-3679. 1999. Effluent and Environmental Monitoring. Fluor Daniel Hanford, Inc., Richland, Washington.

HNF-PRO-454. 1999. Inactive Waste Sites. Fluor Daniel Hanford, Inc., Richland, Washington.

HNF-PRO-455. 2000. Solid Waste Management. Fluor Hanford, Inc., Richland, Washington.

WAC 173-303-145, Washington Administrative Code. Dangerous Waste Regulations (Spills and Discharges into the Environment). Olympia, Washington.

WAC 173-400, Washington Administrative Code. General Regulations for Air Pollution Sources. Olympia, Washington.

WAC 246-247, Washington Administrative Code. Radiation Protection - Air Emissions. Olympia, Washington.

WHC-SD-W058-RPT-001. 1995. Preoperational Environmental Survey Report: 200 Areas Cross-Site Transfer Line Replacement (W-058). A. R. Johnson, R. M. Mitchell, and C. A. Rowley, Westinghouse Hanford Company, Richland, Washington.

WHC-SD-WM-TI-778. 1996. Preoperational/Operational Environmental Survey Report: Solid Waste Operations Complex. R. M. Mitchell and A. R. Johnson, Westinghouse Hanford Company, Richland, Washington.

WMTS-OEM-001. 1999. Operational Environmental Monitoring. Waste Management Federal Services, Inc, Richland, Washington. 


\section{Hanford Site Environmental Monitoring Plan}

\section{Section III.A. Surface Environmental Surveillance}

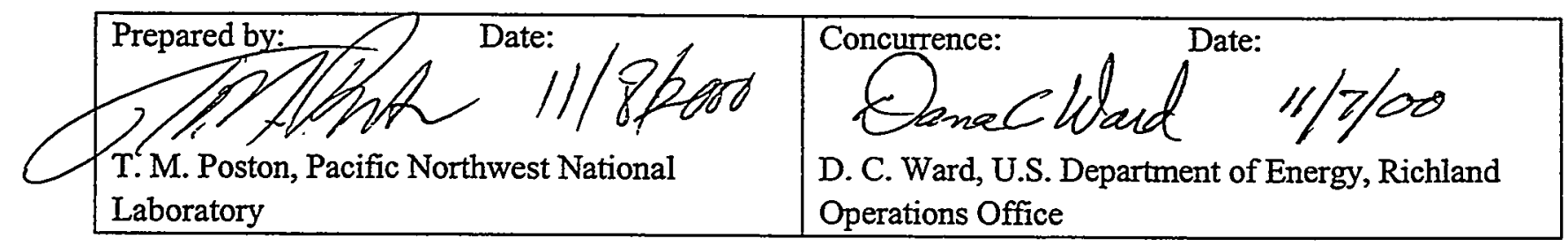




\section{Introduction}

This section describes the Hanford Site plan for surface environmental surveillance. Environmental surveillance includes all components of the surface environment. The purpose of this section is to describe how the surveillance and reporting requirements of U.S. Department of Energy (DOE) Orders 5400.1, 5400.5, and 231.1 and the guidance of DOE/EH-0173T are to be met for the Hanford Site.

The Surface Environmental Surveillance Project, conducted by Pacific Northwest National Laboratory (PNNL), is a multimedia environmental monitoring effort to measure the concentration of radionuclides and chemicals in environmental media and assess the integrated effects of these materials on the environment and the public. Project personnel collect samples of air, surface water, sediments, soil and natural vegetation, agricultural products, fish, and wildlife. Samples are analyzed for very low environmental concentrations of radionuclides and nonradiological chemicals, including metals, anions, and volatile organic compounds. In addition, ambient external radiation levels are measured.

Activities inherent in the operation of the Surface Environmental Surveillance Project include design and implementation, sample collection, sample analysis, database management, data review and evaluation, exposure assessment, and reporting. Other elements of the project include project management, quality assurance and quality control, training, and records management.

The project focuses on routine releases from DOE facilities on the Hanford Site; however, the project is also responsive to unplanned releases and releases from non-DOE operations on and near the site. Surveillance results are provided annually through the Hanford Site environmental report (e.g., PNNL-13230 for 1999). In addition, unusual results or trends are reported to DOE when they occur.

Although the scope of the Surface Environmental Surveillance Project has expanded during recent years to include hazardous chemical surveillance, this plan focuses on radiological surveillance in response to DOE requirements. This plan is written to comply with all "should"" statements in DOE/ EH-0173T unless noted otherwise in the Exceptions discussions. "Should*" statements are described in $\mathrm{DOE} / \mathrm{EH}-0173 \mathrm{~T}$ as flexible guidance; this guidance has been considered in the development of this plan and incorporated where determined appropriate.

This section (III.A) of the plan is related to other sections in several respects. The sampling design described is based on radiological and chemical pathway analyses that utilize the source data obtained under the effluent monitoring program described in Section II.A and the near-facility environmental monitoring program described in Section II.B. The pathway analysis and dose assessment conducted for this plan and the dose assessments reported in the annual Hanford Site environmental report (e.g., PNNL-13230 for 1999) use the dispersion data provided by the Meteorological and Climatological Services Project described in Section III.C. The pathway analyses and dose assessment conducted for this section include the contribution to dose from the groundwater pathway discussed in Section III.B. 
The environmental pathways carrying contaminants to humans and the significance of the media and contaminants to total dose are strongly influenced by the environmental setting. The Hanford Site's environmental setting is summarized in the Hanford Site National Environmental Policy Act (NEPA) Characterization report (PNNL-6415), and will not be described here.

\section{Requirements and Objectives of Environmental Surveillance}

The general requirements and objectives for environmental surveillance are contained in DOE Orders 5400.1 and 5400.5. The broad objectives (DOE Order 5400.1) are to demonstrate compliance with legal and regulatory requirements, to confirm adherence to DOE environmental protection policies, and to support environmental management decisions. These requirements are embodied in the primary surveillance objectives stated in the DOE Orders and DOE/EH-0173T and include the following:

- determine compliance with applicable environmental quality standards and public exposure limits and applicable laws and regulations; the requirements of DOE Orders 5400.1, 5400.5, and 231.1; and the environmental commitments made in environmental impact statements, environmental assessments, safety analysis reports, or other official DOE documents. Additional objectives that derive from the DOE Orders and this primary objective include the following:

- conduct preoperational assessments

- assess radiological doses to the public and aquatic biota from site operations

- assess doses from other local sources

- report alarm levels and potential doses exceeding reporting limits (DOE Order 5400.5, Chapter II, Section 7)

- prepare an annual site environmental report

- maintain an environmental monitoring plan

- determine background levels and site contributions of contaminants in the environment

- determine long-term accumulation of site-related contaminants in the environment and predict trends; characterize and define trends in the physical, chemical, and biological condition of environmental media

- determine effectiveness of treatment and controls in reducing effluents and emissions

- determine validity and effectiveness of models to predict the concentrations of pollutants in the environment 
- detect and quantify unplanned releases

- identify and quantify new or existing environmental quality problems.

DOE/EH-0173T indicates that subsidiary objectives for surveillance should be considered. Subsidiary objectives applicable to the site include the following:

- obtain data and maintain the capability to assess the consequence of accidents

- provide public assurance; address issues of concern to the public, business, and regulators

- enhance public understanding of site environmental impacts, primarily through public involvement and by providing public information

- provide environmental data and assessments to assist DOE in environmental management of the site.

The DOE Orders require that the content of surveillance programs be determined on a site-specific basis by the DOE field offices. The surveillance programs must reflect facility characteristics; applicable regulations; hazard potential; quantities and concentrations of materials released; extent and use of affected air, land, and water; and specific local public interest and concern.

\section{Surface Environmental Surveillance Design}

Environmental surveillance is designed to meet the objectives listed above while considering the environmental characteristics of the site and potential and actual releases from site operations. Surveillance activities focus on determining environmental impacts and compliance with public health and environmental standards or protection guides rather than on providing detailed radiological and chemical characterization. Experience gained from environmental surveillance activities and studies conducted at the Hanford Site for more than 50 years provide valuable technical background for planning the surveillance design.

This subsection discusses the rationale and criteria for environmental surveillance, surveillance design, and the annual surveillance design-review process.

\section{Rationale and Design Criteria}

The rationale and criteria for environmental surveillance are based on the following:

- DOE Orders 5400.1 and 5400.5

- DOE/EH-0173T

- surveillance objectives 
- results of the radiological and chemical pathway analyses

- other site commitments.

The minimum objective criteria for determining the content of surveillance projects are contained in Tables 5-1 and 5-2 of DOE/EH-0173T and Table 4 of Section 7 of EPA-520/1-80-012.

Based on current doses and the above-referenced objective criteria alone, periodic surveillance measurements are required a minimum of every 5 years to confirm that the doses are below the objective criteria.

However, conducting only confirmatory surveillance measurements every 5 years at the site and in the surrounding region would not fully meet the primary surveillance objectives (see Requirements and Objectives of Environmental Surveillance) or satisfy the subsidiary objectives. The rationale and criteria for additional sampling in each medium will be discussed in the subsections that follow. First, there are some general considerations that will be factors in decisions about the content of the surveillance design.

The application of objective criteria from DOE/EH-0173T to the radiological pathway analyses results addresses only surveillance for routine releases and does not consider the inventory potentially available for release. The potential inventory of radioactive materials disposed to the ground at the Hanford Site is very large ( 5.6 million curies). In addition, it is estimated that there are 209 million curies in waste-storage tanks, 174 million curies (cesium and strontium) in capsule storage, 63 million curies in irradiated fuel, 651 thousand curies in stored solids, and 16 million curies in isotopic heat sources. Likewise, the inventory of hazardous chemical waste onsite generated during historical operations is not well quantified or documented and is believed to be of considerable magnitude.

The need for routine surveillance independent of the operating contractor is reinforced by the recognition that expedited cleanup actions under the Hanford Federal Facility Agreement and Consent Order (also known as the Tri-Party Agreement; Ecology et al. 1998) have begun and that cleanup actions will increase and continue over the next few decades. These actions, in some cases applying cleanup technologies that have never been used before, increase the potential for the release to, and migration within, the environment of materials that are currently contained. The design for routine surveillance must address the need to establish baselines to measure the integrated effects of various cleanup actions across the site and to monitor the trends that may result from these operations.

Design rationale and criteria that apply to most media are summarized below.

\section{Media Selection}

Highest priority is given to sampling media that are directly ingested or inhaled by the public. Additional media are selected based on their sensitivity as indicators of loss of control, for their ability to predict accumulations and trends, or as indicators of environmental quality. 


\section{Sampling Locations}

Background sampling locations are established for all media-contaminant combinations routinely sampled or that would likely be sampled to assess the effects of unusual or accidental releases. Sampling locations are selected near potential sources to maximize the probability of detecting losses of containment, to establish baselines, and to assess the effects of releases. Sampling stations are positioned at the site perimeter (near or just inside the site boundary) to estimate conditions at the nearest points at which members of the public reside or could reside. Exposures at these locations are typically the maximum that any member of the public could receive. Finally, sampling is conducted in the community locations where the highest potential chronic effects are expected to occur, both to provide measurements where the most people are potentially exposed and to provide assurance to the communities that levels are well below standards established to protect public health.

\section{Sampling and Analysis Frequencies}

Sampling frequencies are established based on the need to obtain time-representative samples, environmental factors that may impact collection efficiencies, the limitations of the sampling equipment or sampling substrates, and sample availability. Most routine samples are collected weekly, biweekly, monthly, or quarterly. However, some are collected annually, biennially, or every 3 to 5 years. Most samples are submitted for analysis immediately following collection. Some are retained for several weeks or months and composited to increase time representativeness and to lower detection limits. The exposure or sample integration period may be up to 1 year but no more than twice the radionuclide halflife.

\section{Detection and Precision}

The general surveillance criterion is to use the lowest level of detection practical, utilizing standard analytical procedures and considering practical sampling strategy tradeoffs (e.g., time and location compositing versus discrete samples and practical sampling trains). Where technically feasible and practical, the minimum objective for a given medium-radionuclide combination is to detect concentrations at or below the concentration that would result in a dose to humans of 1 millirem per year effective dose equivalent (EDE) if that concentration were sustained for a year. This dose estimate assumes that the radionuclide is being transported to subsequent compartments of the pathway and that the individual is exposed to all subsequent compartments. For example, the limit for air assumes not only inhalation but also exposure from deposition, vegetation uptake, consumption, etc. One millirem is selected as the minimum criterion because it is $10 \%$ of the level at which potential doses to the public must be reported to DOE-Headquarters (HQ), as well as being $10 \%$ of the dose limit ( 40 CFR 61) for the air pathway, thereby providing a high level of assurance that these requirements will be met.

The current detection criteria (by radionuclide and medium) are contained in the subsection entitled Laboratory Procedures. These detection limits are well below the 1-millirem level and are driven by the goal of obtaining the lowest practical level of detection using standard methods. Analytical precision criteria are contained in the subsection entitled Quality Assurance and Quality Control. 
The rationale, design criteria, and plan for surveillance measurements to meet the primary and subsidiary objectives are described in the media-specific subsections.

\section{Dose Assessment}

Pathway and dose assessments are conducted as follows:

- annually to assess compliance with DOE Order 5400.5 public limit and 40 CFR 61 criteria

- annually to determine the minimum needs for environmental surveillance as defined in DOE/EH-0173T

- at least every 5 years to assess compliance with DOE Order 5400.5 interim aquatic biota limit or when exposure conditions have changed significantly, at the discretion of the cognizant PNNL manager.

\section{Surveillance Design}

The Hanford Site Surface Environmental Surveillance Project historically has focused on radionuclides in various media and nonradiological water quality parameters. In recent years, surveillance for nonradiological constituents, including hazardous chemicals, has expanded. A detailed chemical pathway and exposure analysis for the Hanford Site was completed in 1994 (PNNL-10714). The analysis helped guide the selection of chemical surveillance media, sampling locations, and chemical constituents.

Each year, a radiological pathway analysis and exposure assessment is performed. The pathway analysis is based on source-term data and on the comprehensive pathway and dose assessment methodology included in the Generation II (GENM) computer code (PNL-6584) used for estimating radiation doses to the public from Hanford Site operations. The CRITR II computer code (PNL-8150) is used to calculate doses to animals, and manual calculations are used to compute the doses not addressed in the computer codes. The results of the pathway analysis and exposure assessment serve as a basis for future years' surveillance program design.

Exposure is defined as the interaction of an organism with a physical or chemical agent of interest. Thus, exposure can be quantified as the amount of chemical or physical agent available for absorption at the organism's exchange boundaries (i.e., dermal contact, lungs, gut). An exposure pathway is identified based on 1) examination of the types, location, and sources (contaminated soil, raw effluent) of contaminants; 2) principal release mechanisms; 3) probable environmental fate and transport (including persistence, partitioning, and intermediate transfer) of contaminants of interest; and, most important, 4) location and activities of the potentially exposed populations. Mechanisms that influence the fate and transport of a chemical through the environment and influence the amount of exposure a person might receive at various receptor locations are listed below. 
Once a radionuclide or chemical is released into the environment it may be:

- transported (e.g., migrate downstream in solution or on suspended sediment, travel through the atmosphere, or be carried offsite in contaminated wildlife)

- physically or chemically transformed (e.g., deposition, precipitation, volatilization, photolysis, oxidation, reduction, hydrolysis, or radionuclide decay)

- biologically transformed (e.g., biodegradation)

- accumulated in the receiving media (e.g., sorbed strongly in the soil column, stored in organism tissues).

The primary pathways for movement of radioactive materials and chemicals from the site to the public are the atmosphere and surface water. Figures III.A-1 and III.A-2 illustrate these potential routes and exposure pathways to biota and humans, respectively.

The significance of each pathway is determined from measurements and calculations that estimate the amount of radioactive material or chemical transported along each pathway and by comparing the concentrations or potential doses to environmental and public health-protection standards or guides. Pathways are also evaluated based on prior studies and observations of radionuclide and chemical movement through the environment and food chains. Calculations based on effluent data show the expected concentrations off the Hanford Site to be low for all Hanford-produced radionuclides and chemicals and to be frequently below the level that can be detected by monitoring technology. To ensure that radiological and chemical analyses of samples are sufficiently sensitive, minimum detectable concentrations of key radionuclides and chemicals have been established at $10 \%$ of the applicable health standards.

Environmental and food-chain pathways are monitored near facilities releasing effluents and at potential offsite receptor locations. The surveillance design uses a stratified sampling approach to monitor these pathways. Samples are collected, and radionuclide and chemical concentrations are measured in three general surveillance zones that extend from onsite operational areas to the offsite environs.

The first surveillance zone extends from near the operational areas to the site perimeter. The environmental concentrations of releases from facilities and fugitive sources (those released from other than monitored sources such as contaminated soils) generally would be the highest and, therefore, most easily detected in this zone. The second surveillance zone consists of a series of perimeter sampling stations positioned near or just inside the site boundary, along Highway 240, which runs through the site from Richland to the Vernita Bridge, and along the Columbia River. Exposures at these locations are typically the maximum that any member of the public could receive. The third surveillance zone consists of nearby and distant community locations within an 80 -kilometer radius of the site. Surveillance is 


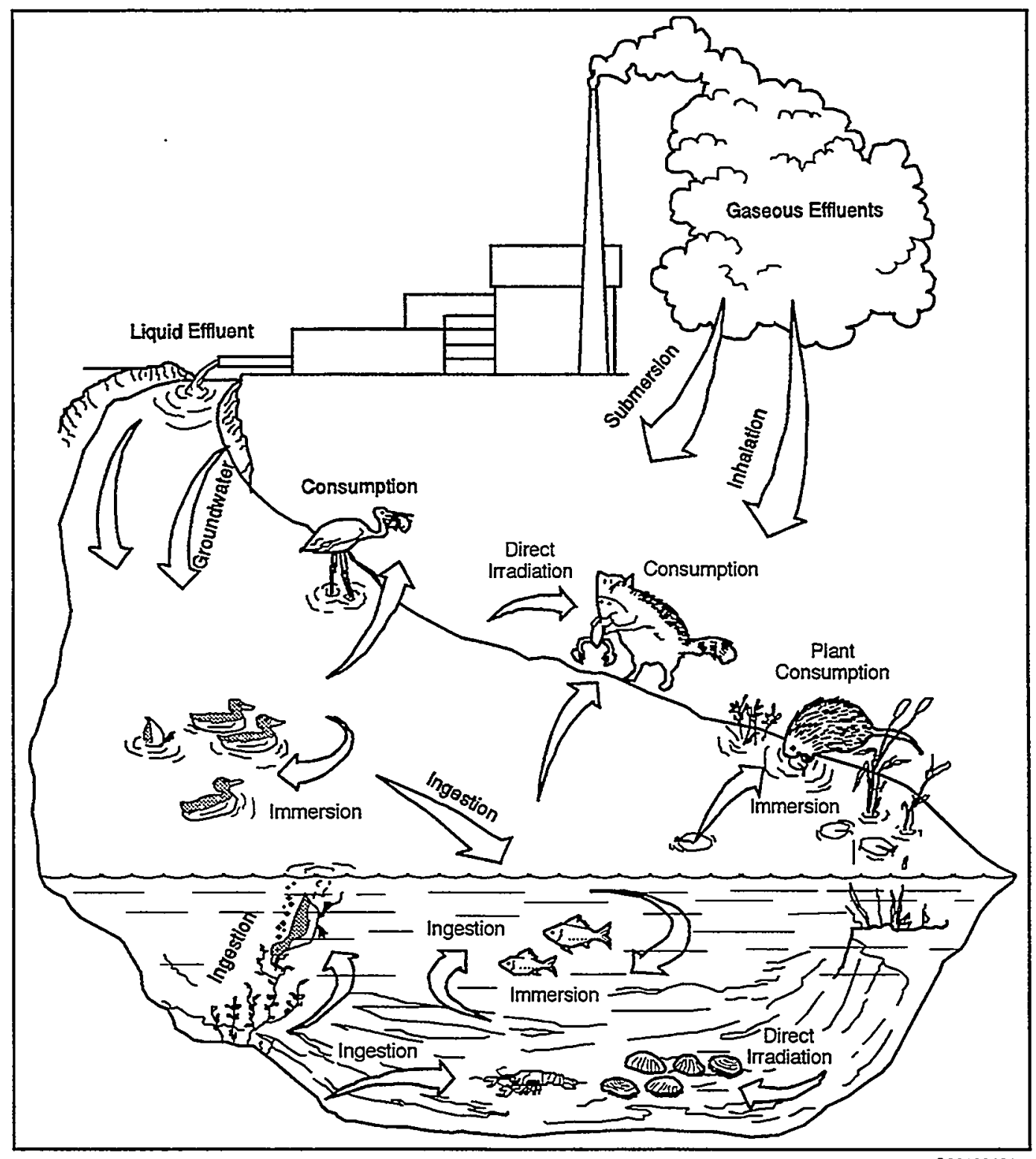

Figure III.A-1. Radiation and Chemical Exposure Pathways to Biota

conducted in communities to obtain measurements at locations where a large number of people potentially could be exposed to Hanford Site releases and to document that contaminant levels are well below standards established to protect public health.

Background concentrations are measured at distant locations and compared with concentrations measured onsite and at perimeter and community locations. Background locations are essentially unaffected by site operations (i.e., these locations could be used to measure ambient environmental levels of chemicals and radionuclides). Comparing background concentrations to concentrations measured on or near the site indicates the impact of site operations. 


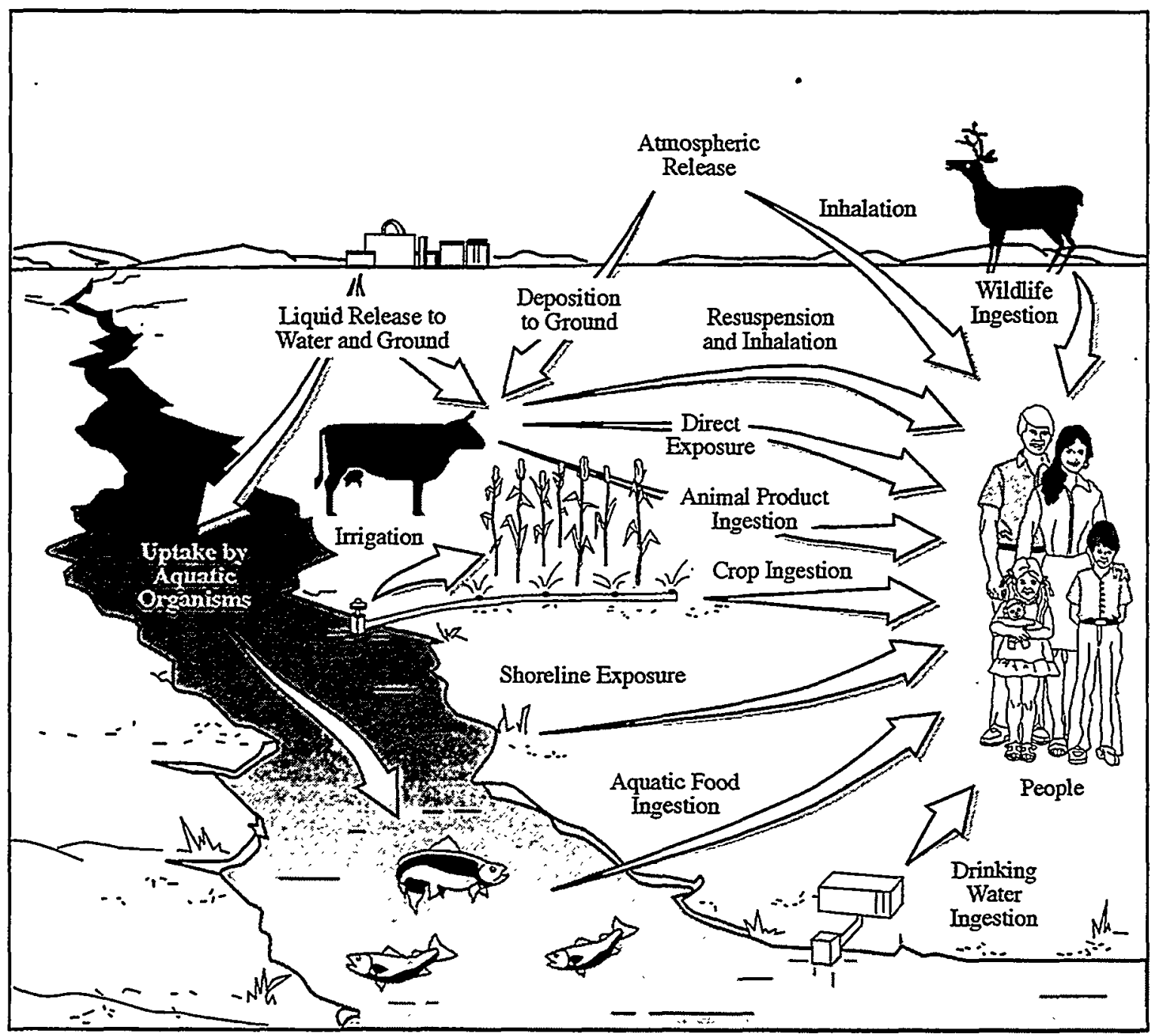

SG97030269.131C

Figure II.A-2. Potential Exposure Pathways to Man

To the extent possible, radiological dose assessments should be based on direct measurements of dose rates and radionuclide concentrations in environmental media. However, the amounts of most radioactive materials released from site operations in recent years generally have been too small to be measured directly once dispersed in the offsite environment. For the measurable radionuclides, often it was not possible to distinguish levels resulting from worldwide fallout and natural sources from those associated with Hanford Site releases. Therefore, offsite doses are estimated using the following methods:

- Doses from monitored air emissions and liquid effluents released to the Columbia River are estimated by applying environmental transport and dose-calculation models to measured effluent monitoring data and selected environmental measurements. Pathway-modeling results are compared to measurable surveillance results to assess model performance, and the results of the comparison are documented. When measured results exceed model results, the measured results are used to adjust the dose results. 
- Doses from fugitive air emissions (e.g., from unmonitored resuspended contaminated soils) are estimated from measured airborne concentrations at site perimeter locations.

- Doses from fugitive liquid releases (e.g., unmonitored groundwater seeping into the Columbia River) are estimated by evaluating differences in measured concentrations upstream and downstream from the Hanford Site.

\section{Annual Design/Review Process}

The design of surface environmental surveillance is reviewed annually based on the above considerations as well as an awareness of planned waste management and environmental restoration activities. The process by which the design is evaluated is both continuous and cyclic. The need for changes in the surveillance design is evaluated continuously during the year in response to changing operations and/or environmental conditions. The design/review process repeats itself each year, using information generated during the previous year as the basis for the evaluation. The final sampling design and schedule are documented annually in a master sampling schedule (e.g., PNNL-13109 for 2000). Key steps in the process are discussed below.

- pathway analysis - The process starts with the radiological pathway analysis performed by PNNL for the calendar year just ended. This analysis is based on a review and report of facility emissions and effluents provided by facility managers (DOE/RL-99-41, HNF-EP-0527-9) and the environmental surveillance results from the previous year. The pathway analysis serves as the basis for the annual Hariford Site environmental report (e.g., PNNL-13230 for 1999) as well as the design review.

- Hanford Site environmental report - The annual environmental report (e.g., PNNL-13230 for 1999) summarizes the findings of the surveillance activities conducted during the previous calendar year. The evaluation of these results plays an integral part in the design evaluation, both in comparisons with the radiological and chemical pathway analyses conclusions and in identifying changes in environmental conditions that may indicate a need for modifications to the sampling plan. The distribution list for the annual report is reviewed to ensure that potentially affected federal, state, and local governments and agencies; Indian Nations; environmental interests; business interests; and owners of Hanford Reach islands are notified concerning the environmental status of the Hanford Site and its surroundings. An electronic version of the report is also posted on the internet. Feedback on report contents and areas of concern relative to project design are considered in the designreview evaluation.

- site activity projection - Because the pathway analyses and the annual report are retrospective, an activity projection from the Hanford Site contractors identifies future activities to be considered in terms of surveillance needs. Resources useful in anticipating future environmental surveillance needs include DOE/RL-96-92, DOE/EM-0327, Ecology et al. (1998), various contractor effluent and operational environmental monitoring plans and results from previous years' monitoring, and bimonthly technical exchanges between environmental monitoring and surveillance personnel within each contractor.

- annual surveillance design evaluation - The above information is considered in the annual surveillance-design evaluation as the basis for planning the surveillance program for the following 
few fiscal years and/or calendar years. Results of field inspections of sampling and measurement locations conducted during the current year are reviewed to determine whether conditions at sampling locations continue to meet site selection and/or sampling design criteria. The design evaluation also includes a review for new surveillance compliance requirements (e.g., DOE Orders, directives, or other applicable federal or state requirements) and DOE/EH-0173T updates. Plans for the following years are discussed with appropriate Hanford Site contractors to ensure that any assumptions implicit in the surveillance project about the availability of related ambient monitoring data are valid and to determine whether recent ambient data indicate conditions or trends that must be considered in the design of the surveillance project. The results of this annual surveillance design evaluation and the action, if any, to be taken in response to changes are documented in the administrative files.

- submit scope and budget for upcoming fiscal years - Based on the results of the annual surveillance design evaluation, the scope and budget information is prepared and submitted for the following few fiscal years. Detail in the out-year scope and budget information is necessarily general in nature; however, it does provide targets on which to base future, more detailed planning and specific scope and budget development.

- project documentation package for next fiscal year - Specific surveillance objectives, work scope, and budget are provided in the project-specific documentation package written for the upcoming (next) fiscal year. The package sets forth the plans and organization that will be used to conduct, control, and document the project and represents an agreement between DOE and Battelle on the objectives, scope, and work to be performed during that fiscal year.

- scope and budget approval - As defined in the project-specific documentation package, the scope and budget are reviewed and approved by DOE typically during the first half of the current fiscal year. Approval of the scope and budget is documented through DOE signature on the current fiscal year package.

- surveillance design update - The annual surveillance design evaluation is documented through updates to the project documentation package and the environmental surveillance master sampling schedule (e.g., PNNL-13109 for 2000). Plans for the following calendar year are developed and discussed with other contractors to coordinate related activities. Plans are also discussed with representatives from the Washington State Department of Health to identify those samples to be included in the cooperative duplicate sampling program.

- develop next calendar year master surveillance schedule - The master sampling schedule (e.g., PNNL-13109 for 2000) for the next calendar year, based on the results of the annual design-review process, is prepared and issued.

- environmental monitoring plan update - This Environmental Monitoring Plan is updated every 3 years (DOE Order 5400.1). Minor annual adjustments in sampling schedules, locations, or methodologies do not warrant revision of the plan but are documented in the project documentation package and master sampling schedule. 


\section{Air Surveillance}

Radioactive particles and gases are released from point sources (stacks and vents) during routine operations in the 100,200,300, and 400 Areas. Diffuse sources consist primarily of contaminated soil in the $100,200,300$, and 600 Areas that can be resuspended by wind. These materials are diluted to low concentrations as they are transported offsite where people may be directly exposed to radionuclides through inhalation or by deposition onto farm crops, native vegetation, and surface soil.

Each year, a radiological pathway analysis and exposure assessment is performed. Recent pathway analyses indicate that the site dose to the maximally exposed individual $(0.008$ millirem in 1999$)$ is well below the level at which routine surveillance is recommended (DOE/EH-0173T). The predominant air pathways are inhalation and air/food.

Fission product and transuranic surface contamination exists in the 200 Areas, and uranium surface contamination exists in and around the 300 Area. There is also a large inventory of buried wastes in the 100,200 , and 300 Areas that represents a potential source not addressed in the pathway dose assessment. Past monitoring data indicate that these sources currently do not represent significant sources for the air pathway. However, because of the large inventory, the potential for biointrusion, and the desire to provide a high level of public assurance, continued routine air surveillance of these source areas is considered necessary to provide an early indication of any loss of control. Each of these areas also contains Comprehensive Environmental Response, Compensation, and Liability Act of 1980 (CERCLA) operable units at which buried wastes will potentially be treated or removed in the future. Air surveillance at the margins of these operable units will provide baseline data before restoration actions (preoperational data) are taken, as well as data to assess the effects of restoration activities.

Each of the four operating areas $(100,200,300$, and 400 Areas) has the potential to initiate a site emergency. Under that designation, there is a potential for an offsite dose of 50 to 1,000 millirems EDE. At this level, there exists a need for near-facility air data to assess impacts resulting from potential accidents and unusual occurrences. To meet these special sampling needs, air samplers must be operated continuously.

Public assurance is an essential element of surveillance at the Hanford Site. Although pathway modeling using operating facility source-term data is a useful tool, the public inherently has more confidence in actual environmental measurements. Sampling near the site perimeter, especially in the downwind sectors, provides data that are compared to background data to estimate the effect of the site at the closest point of actual or potential public residence, as well as to evaluate the pathway models and to estimate doses directly. Measurements in nearby communities provide assurance at those locations where the greatest number of people reside. In many cases, the environmental levels are currently below analytical detection limits. In most cases, exposures at the detection limits would result in doses that are a very small fraction of the dose standards. 


\section{Objectives}

The objectives of air surveillance are the following:

- obtain air concentration measurements at locations of actual and potential public residence to verify that doses to the public through the air pathway from DOE operations remain low relative to standards

- provide early detection of potential increases in public exposures and contamination of the environment through measurements of actual and potential emissions to the air from facilities and areas with surface contamination and buried wastes

- obtain preoperational baseline data and environmental surveillance data for areas near waste units scheduled for treatment and/or restoration to assess the integrated effects of individual site actions and over time

- obtain measurements at the site perimeter and in nearby communities to provide public assurance that the degree of contamination from DOE operations is known

- sample air onsite and offsite continuously to assess the environmental effects and doses from unusual releases

- provide data to evaluate and improve pathway models used to predict and assess public dose compliance and environmental contamination.

\section{Plan Rationale and Criteria}

The criteria for air sampling consist of those identified in DOE/EH-0173T. The actual level of surveillance and specific criteria to meet the site objectives are described below.

The locations, media, sampling frequencies, temporal and spatial compositing, analyses, and analysis frequencies to meet air-surveillance objectives and criteria are given in the annual sampling schedule (e.g., PNNL-13109 for 2000). The calendar year 2000 sampling locations are provided in Figure III.A-3. Sampling locations may change annually. The rationale and any additional specific criteria for these selections are discussed below.

\section{Media Selection}

Air is sampled according to the primary form in which the radionuclides occur. Most of the radionuclides of interest occur in particulate form at the site. Past measurements indicate that iodine occurs predominantly as a gas and tritium as water vapor. 


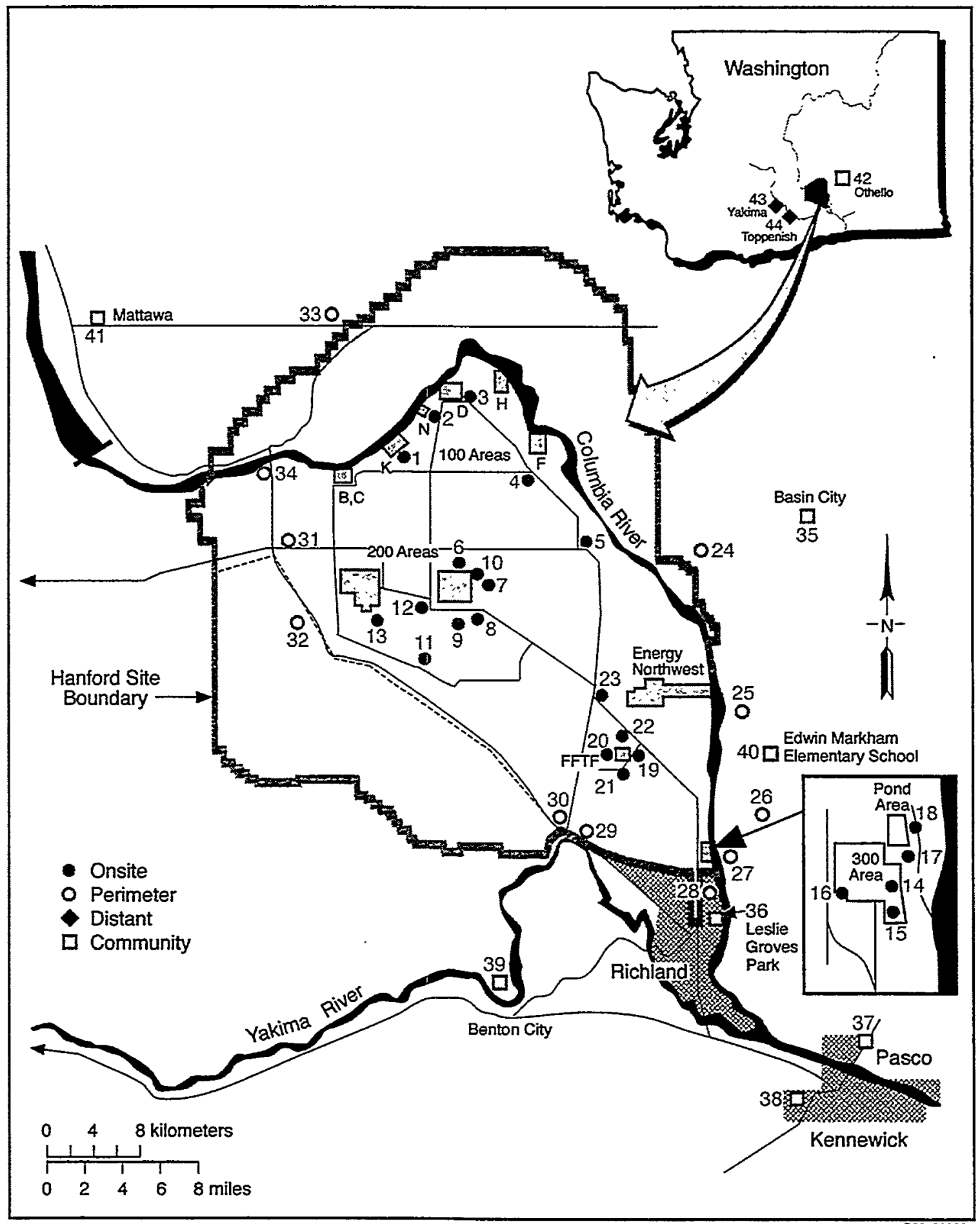

Figure III.A-3. Air Sampling Locations for Calendar Year 2000 


\section{Analyte Selection}

Onsite. Air samples collected downwind near each operating area are field surveyed for alpha and beta-gamma radioactivity with hand-held instruments at the time of collection to verify normal conditions or to detect unusual conditions should they occur. These samples are then analyzed for gross beta and/or gross alpha activity after natural activity has decayed to provide an indication of the levels of contaminants present. The samples are then composited and analyzed for those radionuclides routinely released in measurable quantities as indicated by facility emissions data, for those with potential to be released under plausible abnormal conditions, for those calculated to contribute more than $10 \%$ of the maximally exposed individual dose, and for those of special public or agency interest. These criteria encompass those radionuclides considered necessary to meet technical and public assurance objectives. Compositing and screening techniques may be used to improve detection levels and reduce analysis requirements where screening provides adequate surveillance.

Perimeter. Additional samples are collected near the perimeter of the site, in the downwind direction, and are used to assess operational control and effects of unusual events. These samples are field surveyed and laboratory analyzed for gross alpha and gross beta and are composited to enhance detection sensitivity for gamma-emitting radionuclides and other radiochemical analyses.

Offsite. Samples from the historical maximally exposed individual locations and downwind contaminants are analyzed for measurable radionuclides, those contributing more than $10 \%$ of the maximally exposed individual dose, and those of special public or agency interest.

\section{Sampling and Analysis Frequency}

Sample locations are visited every other week. Site experience indicates that particulate filters must be collected at this frequency to avoid excess particulate buildup on the filters. Following collection, each particulate sample is analyzed for gross beta and/or gross alpha to provide early indication of any loss of control that may require expedited analysis of samples and/or additional or special sampling. Biweekly gamma scan filters from a single location or from multiple locations are composited for quarterly analysis to track trends that are not likely to be detectable in gross activity measurements. Radiochemical analyses (i.e., isotopic uranium, isotopic plutonium, and strontium-90) of filters are performed quarterly to provide data to estimate or bound the human annual dose standards.

Iodine-131 charcoal cartridge samples are no longer routinely collected. With the shutdown of all reactors and fuel reprocessing, there is no active DOE source of this radioisotope. Any iodine-131 released to the environment from past DOE operations would have decayed to undetectable amounts.

Iodine-129 charcoal cartridges and tritium silica gel columns are collected monthly. This is an operationally practical sampling period and has been observed to be short enough to preclude significant breakthrough and loss of sample. Samples are analyzed monthly for tritium. Iodine-129 is the leading contributor to dose through the air pathway. Monthly samples are composited and analyzed quarterly near the source (200-East Area) and at the perimeter and background locations to track shorter-term trends. 
Background locations are sampled for a given constituent at the highest frequency the constituent is sampled onsite or offsite so that data can be compared and analyzed on the same time scale. The sampling schedule is evaluated and prepared annually.

\section{Sampling Location Selection}

Onsite. Downwind of each operating area with significant inventories of nuclear materials, an air sampler is located as near the climatologically predicted maximum impact area as is practical (considering access, power availability, and costs). Additional samplers are located around those areas to increase the likelihood of detecting an unusual occurrence. These additional samplers are distributed azimuthally by wind-direction sector, balancing considerations of wind-direction frequencies, geometric distribution, and practicality. Radial placement is based on the predicted distance of maximum ground-level impact for Class E atmospheric stability (slightly stable) (from Turner 1970, Figure 3-9) to the extent practical. The goal of placing samplers at the Class $\mathrm{E}$ stability maximum ground-level impact distance is a compromise between the desire to sample at the point of maximum ground-level concentration for all stabilities; the desire to be far enough away that an elevated plume will reach the ground at the sampler under all conditions; and the practical recognition that, in general, power is available near the facilities and much less available at increasing distance from the facilities.

Samplers are located with the goal of providing measurements representative of the integrated effects of the areas being monitored, a goal that may require a tradeoff with the goal of measuring the maximum effects.

Perimeter. Additional stations at the perimeter of the site are located to reflect the distribution of source areas across the site.

Offsite. Offsite samplers are located near the maximally exposed individual location to attempt to verify such exposures; in the nearest downwind population center, the Tri-Cities, to bound the maximum exposures at the nearest population center and at the highest frequency wind-direction sectors. In addition, samplers are located in a few selected downwind communities to provide means for public involvement, education, and assurance.

At least one background location a minimum of 20 kilometers from the site in a predominantly upwind direction is sampled for each radionuclide, form, and species sampled onsite or offsite.

Proximity to Obstructions. Samplers are located to obtain concentration measurements representative of open areas (i.e., avoiding significant local effects on the radionuclide concentrations of interest such as those caused by building wake entrainment and vegetation filtration). This approach is expected to provide better comparability of data between locations.

Samplers are placed outside building wake zones, where aerodynamic effects could significantly affect the observed concentrations. This can occur when elevated plumes pass over structures and are entrained and mixed into the wake or when plumes are of the same order or size as the structures they impinge upon. In the latter case, plumes will have a strong concentration gradient, and mixing by a wake can significantly change the concentrations that would otherwise have been observed. After elevated plumes have contacted the ground and at distances where the lateral dimensions of the plume are large 
compared to structures, the effects of the structures on air concentrations about the structures can be expected to be small because the concentration gradients in the air approaching the structure are small. To implement this qualitative model, samplers are located at a distance that is at least three times the height of the building away from the nearest building unless:

- the sampling point is farther from the source than the predicted distance for the ground-level maximum concentration for the applicable effective stack height under Class F atmospheric stability (from Turner 1970, Figure 3-9)

- the lateral plume width (4x y from Turner 1970, Figure 3-2) under Class F atmospheric stability (moderately stable) conditions is at least 10 times $\mathrm{L}$, where $\mathrm{L}$ is the largest dimension of the building.

Samplers near trees or other elevated vegetation can be influenced by the same effects. Isolated trees can be expected to cause less flow obstruction but can represent greater sinks for some radionuclides. Based on these considerations, samplers are placed at a distance at least two times the height of isolated trees and at three times the height of rows or stands of trees at all locations.

Application of these criteria is necessarily constrained by accessibility and the cost of providing electrical power. At some locations, it may not be practical to meet the desired criteria.

Sampling inlets are located 2 meters above the ground to provide measurements representative of radionuclide concentrations inhaled by humans.

\section{Sampling or Measurement Method Selection}

Particle sampling is accomplished with glass fiber filters with manufacturer's documentation of a sampling efficiency of at least $99 \%$ for 0.3 -micron dioctyl phthalate particles at the flow rate being used ( 2.6 cubic meters per hour).

When iodine-131 analysis might be necessary, samples are collected on activated charcoal with manufacturer-documented collection efficiencies for the flow rate (2.6 cubic meters per hour), bed depth (2.5 centimeters), and exposure periods used (14 days). Samples for iodine-129 analysis are collected on petroleum-based (low-background) charcoal specially prepared by PNNL; the collection efficiency is verified; and the flow rate is 2.6 cubic meters per hour, with a bed depth of 2.5 centimeters, and an exposure period of 28 days. Both types of iodine sample traps are preceded in the sampling train by a disposable filter to remove particles.

Samples for tritium analysis are collected on silica gel for identifying the tritiated water in air component. Flow rates ( 0.011 cubic meters per hour), media volumes, and exposure periods (28 days) are such that the media are not likely to be saturated during the sampling period. Silica gel saturation is monitored using a color-change indicator, which is useful in diagnosing sampling problems.

Flow rates for air samples are measured at the beginning and end of each sampling period with a device with a documented accuracy of $\pm 20 \%$. 


\section{Sample Handling/Treatment Methods}

Air samples are collected in a manner that avoids loss of sample mass, cross contamination, or misidentification. This is accomplished by exchanging whole sample collection media containers, rather than handling the collection media in the field, and by labeling and sealing or storing each sample so that sample integrity as it is collected in the field is maintained. Sample-collection and -handling procedures are described in PNL-MA-580.

\section{Analytical Methods}

Analytical methods are selected to meet the minimum goal of detecting levels equivalent to a dose of 1 millirem if that concentration were sustained for a year. An additional goal is to achieve the lowest detection levels available using standard state-of-the-art analytical methods. The detection levels and analytical methodology are summarized in the subsection entitled Laboratory Procedures.

\section{Quality Control Methods}

Air surveillance is controlled under the overall project QA and analytical control program described in the subsection entitled Quality Assurance and Quality Control.

\section{Reporting/Alarm Levels}

Anomalous results are flagged by computer screening of reported data as they are entered into the project database. Levels for reporting to DOE have been established and are listed in the subsection entitled Records Management and Reporting. Reporting levels are equivalent to the concentration that might lead to a maximally exposed individual dose of 1 millirem EDE if it were sustained for a year. This reporting level provides early indication of conditions that might eventually require reporting to DOE-HQ, as required by DOE Order 5400.5 .

\section{Exceptions}

No exceptions have been taken to "should*" statements in DOE/EH-0173T.

\section{Surface-Water Surveillance}

The Columbia River flows through the northern edge of the Hanford Site and forms part of the site's eastern boundary. The Hanford Reach of the Columbia River extends from Priest Rapids Dam to the head of Lake Wallula (the impoundment created by McNary Dam). Priest Rapids Dam is the nearest dam upstream of the site and McNary Dam is the nearest downstream.

In addition to the Columbia River, other surface waters exist at the Hanford Site. These include a naturally occurring pond (West Lake), Rattlesnake Springs, and two intermittently flowing streams (Dry 
and Cold Creeks), as well as other small springs on the Fitzner/Eberhardt Arid Lands Ecology Reserve. Riverbank springs (i.e., groundwater discharge) occur along the Hanford Reach of the Columbia River as well. Other surface waters include the Fast Flux Test Facility process water ponds and an offsite irrigation system that uses Columbia River water obtained downstream of the Hanford Site.

The Columbia River has been developed extensively for hydroelectric power, flood control, navigation, irrigation, and industrial water supplies. The river is used as a source of drinking water at onsite facilities as well as at communities located downstream of the site. In addition, the river and its shoreline are used for a variety of recreational activities, including hunting, fishing, boating, water skiing, wind surfing, picnicking, and swimming. The Hanford Reach of the Columbia River and some of the surrounding lands have recently been established as a United States National Monument (65 FR 114).

Pollutants resulting from past and current operations at the Hanford Site, both radiological and nonradiological, are known to enter the Columbia River. In addition to U.S. Environmental Protection Agency (EPA)-permitted direct discharges of liquid effluents from onsite facilities, contaminants from past waste-disposal practices seep into the river through riverbank springs and subsurface groundwater discharges.

The surface-water pathway (Columbia River) has consistently been one of the primary contributors to the potential dose received by the public as a result of operations at the Hanford Site.

Discharges to the Columbia River and Fast Flux Test Facility pond are monitored by Fluor Hanford, Inc. (and its affiliate companies). Requirements of DOE/EH-0173T identify the need for monitoring two media in the pathway of concern (one of which can be the effluent) as part of the routine surveillance program. As such, periodic sampling of the surface waters is conducted as part of the surface surveillance conducted by PNNL. Such sampling also provides a means of verifying existing effluent-control and effluent monitoring systems. Unplanned releases may also be detected through routine sampling of these media.

Site-specific surveillance identified the need to evaluate long-term trends and to detect changes in environmental conditions as a result of Hanford Site operations. In addition, it is essential that the location and concentrations of contaminants entering the Columbia River be known. Periodic sampling of riverbank springs verifies the levels of contaminants identified in the local groundwater and confirms the discharge of certain constituents into the river. Activities designed to provide these capabilities are maintained as appropriate.

The state of Washington has classified the stretch of the Columbia River from Grand Coulee Dam to the Washington-Oregon border, which includes the Hanford Reach, as Class A, Excellent (WAC 173-201A). Water quality criteria and water use were established in conjunction with this designation. Water quality monitoring is necessary to determine compliance with these criteria.

The Columbia River and the potential impact of Hanford Site operations on the quality of river water have received increasing public scrutiny and concern during recent years. Public interest groups conducted surveillance along the Hanford Reach and raised many questions and concerns. Surface watersurveillance activities initiated in the past to address such public concerns and to provide public reassurance will be continued. 


\section{Objectives}

The objectives of surface water surveillance include the following:

- assess impacts of Hanford Site operations on the water quality of the Columbia River

- identify significant changes in the concentrations of contaminants (radiological and chemical) in surface water

- verify adequacy of effluent monitoring and controls

- characterize contaminants in the surface-water environment

- determine status of compliance with applicable water quality standards

- provide public reassurance that risks associated with the use of the Columbia River are low and are being evaluated on a continuous basis.

\section{Plan Rationale and Criteria}

The basis for the design of the surface-water-surveillance program is discussed in DOE/EH-0173T. In addition, other environmental monitoring guides and references were considered in the development of the Hanford Site's surface-water-surveillance program. Similarly, references and guidance specific to water quality monitoring and water sample collection were used in developing sampling protocols.

The surface-water-sampling schedule is produced annually (e.g., PNNL-13109 for 2000). The media, locations, sample types, frequency, and analyses are included in the sampling schedule.

All surface-water samples are collected in accordance with documented, reviewed, and approved collection procedures. Applicable sample-collection procedures are described in PNL-MA-580. As part of the overall Hanford Site environmental monitoring effort, selected duplicate samples are collected with the Washington State Department of Health as noted in the annual sampling schedule (e.g., PNNL-13109 for 2000).

\section{Media Selection}

As previously discussed, contaminants are known to enter the Columbia River as a result of past and current operations at the Hanford Site. Consumption of water or biota from the Columbia River or foodstuffs produced on land irrigated with Columbia River water could expose the public to these contaminants. Additionally, public exposure could occur by direct exposure from water recreation. The Columbia River is routinely monitored to measure the potential exposure from these pathways.

Riverbank springs (groundwater discharge) containing contaminants enter the river along the Hanford Reach shoreline. The springs are monitored periodically to document the locations and levels of 
contaminants entering the river. Such monitoring also confirms the findings of the Hanford Groundwater Monitoring Project relative to the extent of the contaminated groundwater plumes at the Hanford Site.

Onsite ponds, while not directly accessible to the public, are used by migratory waterfowl and wildlife that.could migrate off the site and be harvested and consumed by the public. Onsite ponds are monitored to determine the potential for exposure to the public from this pathway and to verify existing effluent controls.

Offsite irrigation water may be impacted by site operations. Public concerns with respect to the quality of irrigation water and the potential for degradation as a result of site activities have been expressed. Periodic monitoring provides reassurance that irrigation water quality is not impacted by Hanford Site operations.

The following provides a description of the monitoring activities specific to each medium identified above.

\section{Columbia River}

Analyte Selection. Columbia River water samples are analyzed for those constituents that, as determined by pathway analyses, represent a significant fraction of the potential dose from the water pathway. In addition, contaminants of public concern are included in the analyses. In general, analyses include those contaminants known or suspected to be present in the river water as a result of past or current Hanford Site operations. Constituents that have been documented to be consistently below measurable levels have been removed from the sampling schedule.

Radiological analyses of water samples include gross alpha, gross beta, gamma scan, tritium, isotopic uranium, strontium-90, technetium-99, iodine-129, and plutonium-239/240. Gross alpha and gross beta measurements provide a general indication of the radioactive contamination. Gamma scans provide the ability to monitor for numerous specific gamma-emitting radionuclides, including cobalt- 60 , ruthenium-106, antimony-125, cesium-137, and europium-154, as well as others. Highly sophisticated radiochemical analytical techniques and, in some cases, special sampling techniques are used to determine the concentrations of tritium, strontium-90, technetium-99, iodine-129, uranium-234, uranium-235, uranium-238, and plutonium-239/240 in water. Radionuclides of interest are selected based on their importance in determining water quality, in verifying effluent-control and -monitoring systems, and in determining compliance with applicable standards. Where warranted, the half-lives of specific radionuclides are considered in determining sampling and analysis frequencies.

Chemical contaminants analyzed for in water samples include volatile organic compounds, metals, and anions. In addition to monitoring conducted by PNNL, water quality measurements are also performed by the U.S. Geological Survey. The U.S. Geological Survey samples are analyzed for numerous physical, biological, and chemical constituents, including temperature, $\mathrm{pH}$, turbidity, dissolved oxygen, suspended solids, dissolved solids, conductivity, hardness, alkalinity, phosphorus, chromium, iron, and nitrate.

Sampling Location Selection. Routine Columbia River water sample collection locations are identified in Figure III.A-4. Samples are collected upstream of Hanford Site facilities at Priest Rapids Dam 


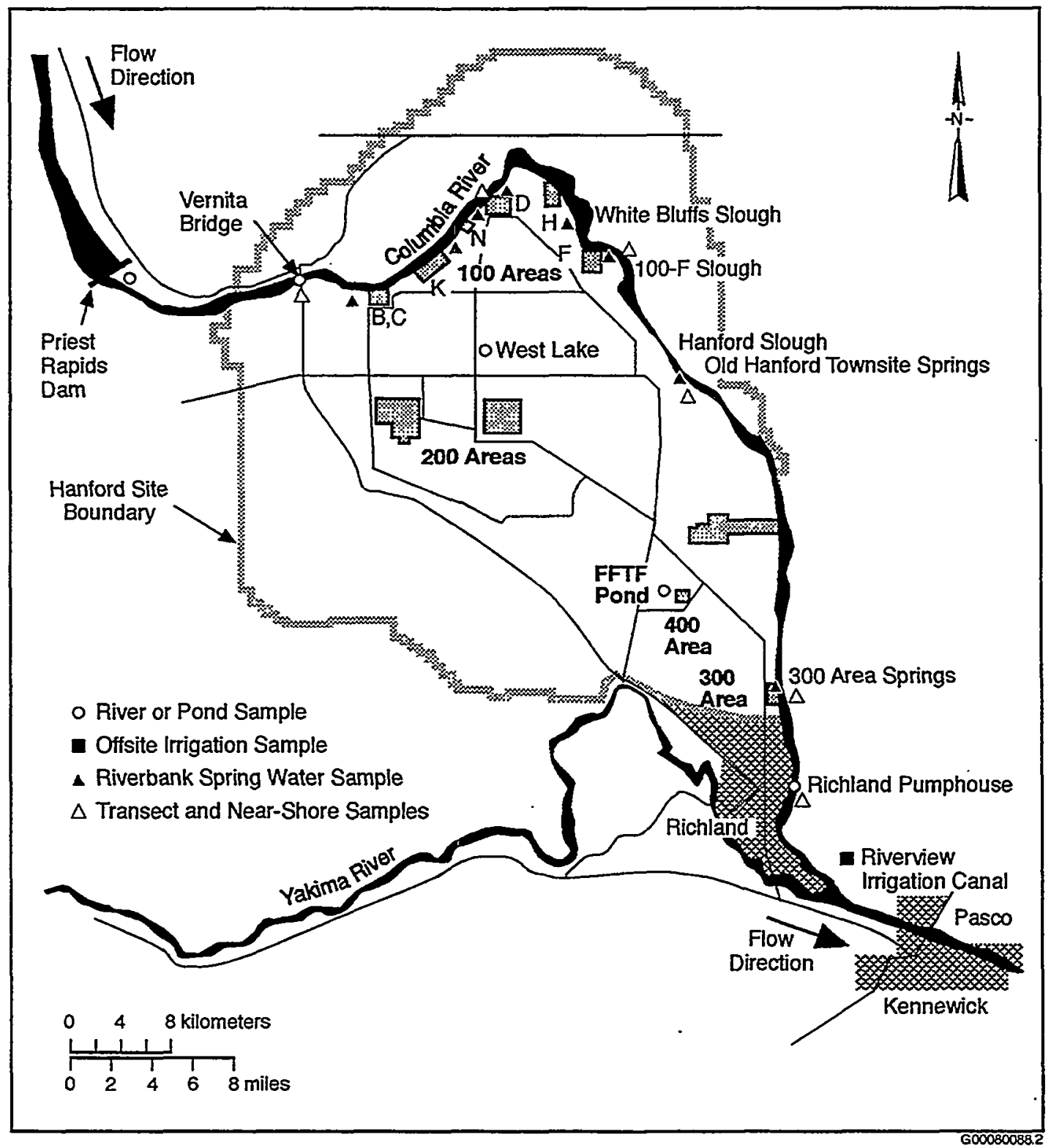

Figure III.A-4. Sampling Locations for Surface Water

and near the Vernita Bridge to provide background data from locations unaffected by site operations. Samples are collected downstream of Hanford Site facilities at the Richland Pumphouse to identify any increase in contaminant concentrations caused by site operations. The Richland Pumphouse, operated by the city of Richland, is the first downstream point of river-water withdrawal for a public drinking water supply. As such, this location provides an upper estimate of the amount of radioactive material in the water supply of the potentially affected population group(s) downstream of the Hanford Site.

Priest Rapids Dam is located approximately 8 kilometers upstream of the site boundary and 20 kilometers upstream of the 100-B Area. The water sampler at Priest Rapids Dam is positioned approximately midstream within the dam and collects water from the reservoir behind the dam. The Vernita Bridge sampling location is approximately 6 kilometers upstream of the 100-B Area. 
The Richland Pumphouse is located approximately 3 kilometers downstream of the site boundary and approximately 5 kilometers downstream of the effluent discharge farthest downstream. The project water-sampling intake is located with the city of Richland drinking water supply intake on the Benton County shoreline, approximately 9 meters into the river. Historical environmental monitoring reports indicate this to be the drinking water supply having the maximum radionuclide concentrations downstream of the Hanford Site (BNWL-90, BNWL-316, BNWL-439, BNWL-983, BNWL-1341, BNWL1505, BNWL-1669, HW-80991). Past sampling along transects near this location indicated that concentrations of gross beta activity and tritium are slightly elevated near the Benton County shoreline (HW-69369, PNL-8531). In 1999, water samples collected at the Richland Pumphouse had statistically elevated concentrations of tritium and iodine-129 compared to samples collected at Priest Rapids Dam (PNNL-13230).

Transect and near-shore sampling is conducted near the Vernita Bridge, 100-N Area, 100-F Area, Old Hanford Townsite, 300 Area, and Richland Pumphouse. Transect sampling is performed to determine the distribution of contaminants across the river at these locations. Near-shore and transect sampling are used to determine the localized zone of influence near known discharges of contaminated groundwater via riverbank springs. The representativeness of the single-point-intake sampling system located at the Richland Pumphouse is also evaluated using results of the transect sampling. Samples along the transects are collected at approximately mid-depth and at several points (up to 10) across the river. Transect sampling will identify those contaminants that are measurable in the river and which may be influenced by proximity to the contaminated groundwater plume. Near-shore samples (up to 5 stations centered around the transect location) are collected at approximately mid-depth near the Hanford shoreline. Near-shore samples provide information on the concentrations of contaminants where the groundwater plumes interact with the Columbia River.

Sampling or Measurement Methods Selection. The sample types, collection method, sample size, and sampling and analysis frequencies are discussed below. The selection of sampling methods and equipment depends on the potential for fluctuations in contaminant concentrations, variability in the effluent release into the receiving water, potential for significant environmental or human impact, and characteristics of the contaminant of interest.

Two types of water-sampling systems are used to collect radiological samples: 1) a cumulative system that collects a fixed volume of water at set intervals at each location during each sampling period and 2) a specially designed system that continuously collects waterborne radionuclides from the river on a series of filters and a mixed-bed ion-exchange resin column. Flow-proportional sampling is desirable; however, because of the extremely large size of the Columbia River, such a system is not practical. Manual composites are collected in those cases where the use of automatic units is not feasible and to cover periods of equipment downtime. Sample size is determined by the requirements of the analytical method to be used and the required levels of sensitivity.

Cumulative sampling systems are operated at Priest Rapids Dam and the Richland Pumphouse and consist of timer-activated units that periodically collect water from a continuously flowing substream of Columbia River water into a 10 -liter container. The sampling sequence includes a pre- and postsubsample air purge to avoid cross contamination between the individual sample aliquots. The cycle is repeated throughout a 1-week sampling period such that approximately 55 milliliters of water are collected every hour. The 10-liter sample container is changed every week, and the sample is taken to 
the laboratory, where water from each location is composited over a 4-week period, resulting in a total sample size of approximately 40 liters. Analyses are performed on these samples according to the current sampling schedule (e.g., PNNL-13109 for 2000).

Continuous sampling systems are located at Priest Rapids Dam and Richland Pumphouse. A special, continuously flowing system is used to separate radionuclides from the river water before analysis. A large volume of water is required to allow the extremely small concentrations of these radionuclides to be detected. River water is pumped through the collection system at a rate of approximately 50 milliliters per minute, resulting in a total sample volume of approximately 1,000 liters during each 2-week sampling period. Suspended particles less than $0.45 \mu \mathrm{m}$ in diameter are removed on a series of filters. Soluble radionuclides, except tritium, are collected on a mixed-bed ion-exchange resin column. The filters and ion-exchange resin are changed every 2 weeks, composited by location, and analyzed on a quarterly basis according to the current sampling schedule (e.g., PNNL-13109 for 2000).

Grab samples of Columbia River water are collected quarterly or annually along cross sections at transect and near-shore sites near the Vernita Bridge, 100-N Area, 100-F Area, Old Hanford Townsite, 300 Area, and Richland Pumphouse for analyses of various radiological and nonradiological water quality parameters. The requirement for minimum holding and transport times prohibits the use of composite systems for these analyses. Special care is taken to obtain water from a flowing portion of the river, avoiding stagnant backwater areas. Surface debris and bottom sediment are also avoided during sampling by collecting the samples from approximately mid-depth. Samples are delivered to the laboratory, where processing is initiated promptly to ensure sample integrity. Samples are collected according to the current sampling schedule (e.g., PNNL-13109 for 2000).

In addition to monitoring conducted by PNNL, water quality measurements are also performed by the U.S. Geological Survey at Vernita Bridge and Richland. These samples are collected quarterly. Numerous physical, biological, and chemical constituents are analyzed for by their laboratory in Denver, Colorado. In addition to sampling, the U.S. Geological Survey provides flow-rate measurements at the Priest Rapids Dam gauging station, near the upstream boundary of the site.

Sample Handling/Transport Methods. Steps are incorporated in the sampling procedure to avoid misidentification and cross contamination of the samples being collected. QA is established and implemented by PNNL's Standards-Based Management System (PNNL 2000). Chain-of-custody procedures, to ensure the integrity of the sample throughout the collection-transport-analysis process, are detailed in PNNL (2000) and PNL-MA-580.

Analytical Methods. Analytical methods are selected to meet the minimum goal of detecting levels equivalent to a dose of 1 millirem if that concentration were sustained for a year. An additional goal is to achieve the lower detection levels available using standard state-of-the-art analytical methods. These goals are summarized in the Laboratory Procedures subsection of Section III.A. In some cases, special techniques have been developed and are used to measure specific contaminants known to be discharged into the surface waters. Analytical methods and detection limits are summarized in the Laboratory Procedures subsection. 


\section{Riverbank Springs}

Routine riverbank spring sample locations were given in Figure III.A-4. Samples are collected annually along the shoreline of the 100-B/C Area, 100-K Area, 100-N Area, 100-D Area, 100-H Area, 100-F Area, downstream of the Old Hanford Townsite, and at the 300 Area. Groundwater enters the Columbia River at these locations, with some contaminant concentrations significantly higher than background.

Water samples collected at these locations are analyzed for those constituents known or suspected to be present in the local groundwater. The primary radionuclides of concern include tritium, uranium, strontium-90, technetium-99, and iodine-129. Chemical contaminants of concern include metals (primarily chromium), volatile organic compounds, and anions.

Samples are typically collected using a siphon pump directly in an improved discharge zone to avoid agitation of the sediment. The sampling zone of the riverbank spring is improved by scooping the sediment away from the discharge area and allowing the disturbed sediment to settle before the siphon pump is used. Riverbank spring samples are handled and transported in a manner similar to the river-water samples discussed above.

\section{Onsite Ponds}

Sampling Locations. Two onsite ponds (see Figure III.A-4), located near operating areas, are routinely sampled. West Lake, located north of the 200-East Area, is recharged from groundwater (ARH-CD-775). This lake has not received direct effluent discharges from site facilities, and radionuclide concentrations are influenced by the local groundwater. The Fast Flux Test Facility Pond, located near the 400 Area, was used for the disposal of water from various facilities in the 400 Area. Fluor Hanford, Inc. (and its affiliate companies) is responsible for monitoring effluents discharged to the Fast Flux Test Facility pond and for operational surveillance of the pond (HNF-EP-0573-5).

Sample Collection and Analysis. Grab samples (10 liters) are collected quarterly from each pond. Care is taken to avoid surface debris and resuspension and inadvertent collection of bottom sediments. Unfiltered aliquots of the samples are analyzed for gross alpha and gross beta activities, gamma-emitting radionuclides, tritium, strontium-90, technetium-99, and uranium (West Lake only) according to the current sampling schedule (e.g., PNNL-13109 for 2000).

\section{Offsite Irrigation Water}

Samples are collected from an irrigation canal that obtains water from the Columbia River downstream of the Hanford Site (see Figure III.A-4). Consumption of food irrigated with Columbia River water from downstream of the site was identified as a pathway contributing to the potential dose to the hypothetical maximally exposed individual in 1996 (PNNL-11472).

The Riverview irrigation canal is sampled and analyzed for gross alpha, gross beta, gamma emitters, tritium, strontium-90, uranium-234, uranium-235, and uranium-238 according to the current sampling 
schedule (e.g., PNNL-13109 for 2000). Strontium-90 is the primary radionuclide of concern because it was identified as one of the primary contributors to the calculated hypothetical dose to the public via the water pathway (PNL-6464).

\section{Quality Control Methods}

Surface-water surveillance is controlled under the overall project QA and analytical control program described in the subsection entitled Quality Assurance and Quality Control.

\section{Reporting/Alarm Levels}

Anomalous results are flagged by computer sereening of reported data as they are entered into the Hanford Environmental Information System (HEIS) database. Levels for reporting to DOE have been established and are listed in the Records Management and Reporting subsection. Reporting levels are equivalent to the concentration that might lead to a dose of 1 millirem EDE to the maximally exposed individual if it were sustained for a year. This reporting level provides early indication of conditions that might eventually require reporting to DOE-HQ as required by DOE Order 5400.5 .

\section{Exceptions}

No exceptions have been taken to "should"” statements in DOE/EH-0173T.

\section{Sediment Surveillance}

As a result of Hanford Site operations, large quantities of radioactive materials were discharged to the Columbia River. On release to the river, the radioactive materials were dispersed rapidly, sorbed onto inorganic particles and detritus, incorporated into aquatic biota, and deposited on the riverbed as sediment. Fluctuations in the river-flow rate, as a result of the operation of hydroelectric dams, annual spring freshets, and occasional floods, have resulted in the resuspension, relocation, and redeposition of the contaminated sediment.

Since the shutdown of the original single-pass cooling reactors, the radionuclide burden in the riversurface sediment has been decreasing as a result of radioactive decay and subsequent deposition of uncontaminated material. However, discharges of some radionuclides to the Columbia River still occur through the seepage of contaminated groundwater into the river. It is expected that some of these radionuclides are either deposited directly or sorbed onto the sediment materials and deposited on the river bottom.

The accumulation of radioactive materials in sediment can lead to exposure of humans through ingestion of aquatic species, through sediment resuspension into drinking water supplies, or as an external radiation source irradiating people fishing, wading, sunbathing, or participating in other recreational activities associated with the river and shoreline. 
Public exposures are well below the level at which routine surveillance of the sediments is required (DOE/EH-0173T). However, periodic sampling is necessary to confirm the low levels and to ensure that no significant changes have occurred over time that may increase the potential exposure to the public through this pathway.

Sampling on a routine basis is necessary to meet site-specific surveillance requirements (DOE/ $\mathrm{EH}-0173 \mathrm{~T}$ ). It is imperative that the whereabouts and fate of the contaminants known to enter the river along the Hanford Reach be understood. Because the source of radionuclides entering the river is predominantly the seepage of contaminated groundwater, sampling of the sediments and river water near the discharge zones provides an indication of the levels entering the river and also confirms findings of the Hanford Groundwater Monitoring Project conducted at the Hanford Site.

Public concern about the levels of contamination in the river sediments and the potential for these contaminants to be resuspended and relocated, perhaps in areas of public use, is evident in the Hanford Site area. Routine sampling of the sediment material provides the public a degree of assurance that both the potential problem (resuspension and redistribution of contaminated sediment). and their concerns are being considered and addressed appropriately.

\section{Objectives}

The objectives of sediment surveillance include the following:

- verify that doses caused by Hanford Site operations through this pathway remain low, by means of periodic river system evaluation, sampling, and analysis

- provide an indication of changes in environmental conditions with potential for increases in public exposures

- provide public assurance in the credibility of site surveillance and that the radiological conditions and potential exposure pathways are understood and receive appropriate attention.

\section{Plan Rationale and Criteria}

The basis for sampling sediment from surface water is discussed in DOE/EH-0173T. In addition, other environmental monitoring guides and references have been considered in the development of the sediment sampling plan. The locations, sampling frequencies, and analyses performed routinely on sediment samples are established annually (e.g., PNNL-13109 for 2000). Additional rationale and specific criteria are described below.

\section{Media Selection}

Sediments along the Hanford Reach are known to contain elevated concentrations of radionuclides and produce higher-than-normal levels of external radiation. Contaminants in sediments may lead to public exposure through the ingestion of aquatic species, through sediment resuspension into drinking water systems, and as an external radiation source. Sediment sampling and the measurement of external 
radiation emanating from the sediments provide indications of the potential for human exposure from this pathway. Sediments are sometimes more sensitive indicators of waterborne contaminants than water or aquatic biota because some contaminants may accumulate in sediments.

All sediment samples are collected in accordance with documented, reviewed, and approved collection procedures contained in PNL-MA-580. Analytical methods are summarized in the subsection entitled Laboratory Procedures.

\section{Analyte Selection}

Sediment samples are analyzed for contaminants known or suspected to be present as a result of past or current operations at the Hanford Site. Effluent discharge reports are reviewed to identify contaminants currently entering the river. Groundwater-monitoring reports identify those contaminants near the river and potentially entering the river that must be considered in the sampling plan. Historic reports, documenting past releases or sediment-contaminant concentrations, are reviewed to determine contaminants of concern as a result of past operations.

Sediment samples are routinely analyzed for gamma-emitting radionuclides (gamma scan), strontium-90, uranium-235, uranium-238, plutonium-238, and plutonium-239/240, according to the current sampling schedule (e.g., PNNL-13109 for 2000). Such analyses are consistent with past and current releases and historical data relative to contaminants in the sediments. In addition, sediment samples are routinely analyzed for metals.

\section{Sampling Frequency}

Sampling of sediments is conducted on an annual basis. This is deemed satisfactory because the sediments are not in a critical exposure pathway to the public. Sampling is conducted consistent with spring freshets (i.e., sampling occurs after the spring high water to provide a consistent and more easily interpreted information base).

Core samples, to determine the fate and buildup of contaminants in the sediment over time, may be collected periodically, commensurate with findings of past core-sampling activities and in consideration of future activities that may resuspend and redistribute the sediment.

\section{Sampling Location Selection}

Samples of Columbia River sediment are collected at the locations shown in Figure III.A-5. Samples are collected upstream of the Hanford Site (beyond the influence of Hanford Site facilities) behind Priest Rapids Dam. Samples are collected downstream of the Hanford Site at Richland and behind McNary Dam (the nearest downstream impoundment). Up to four samples are collected behind each of the dams at approximately equal distances along a sample transect. This provides additional information relative to the distribution of contaminants in the sediments across the river. In addition, samples are collected along the Benton County shoreline of the Hanford Reach, at locations nearer the discharges (past and current), in areas where material is known to be deposited, and in areas commonly used by the public. These locations include the White Bluffs, 100-F, and Hanford Sloughs. 


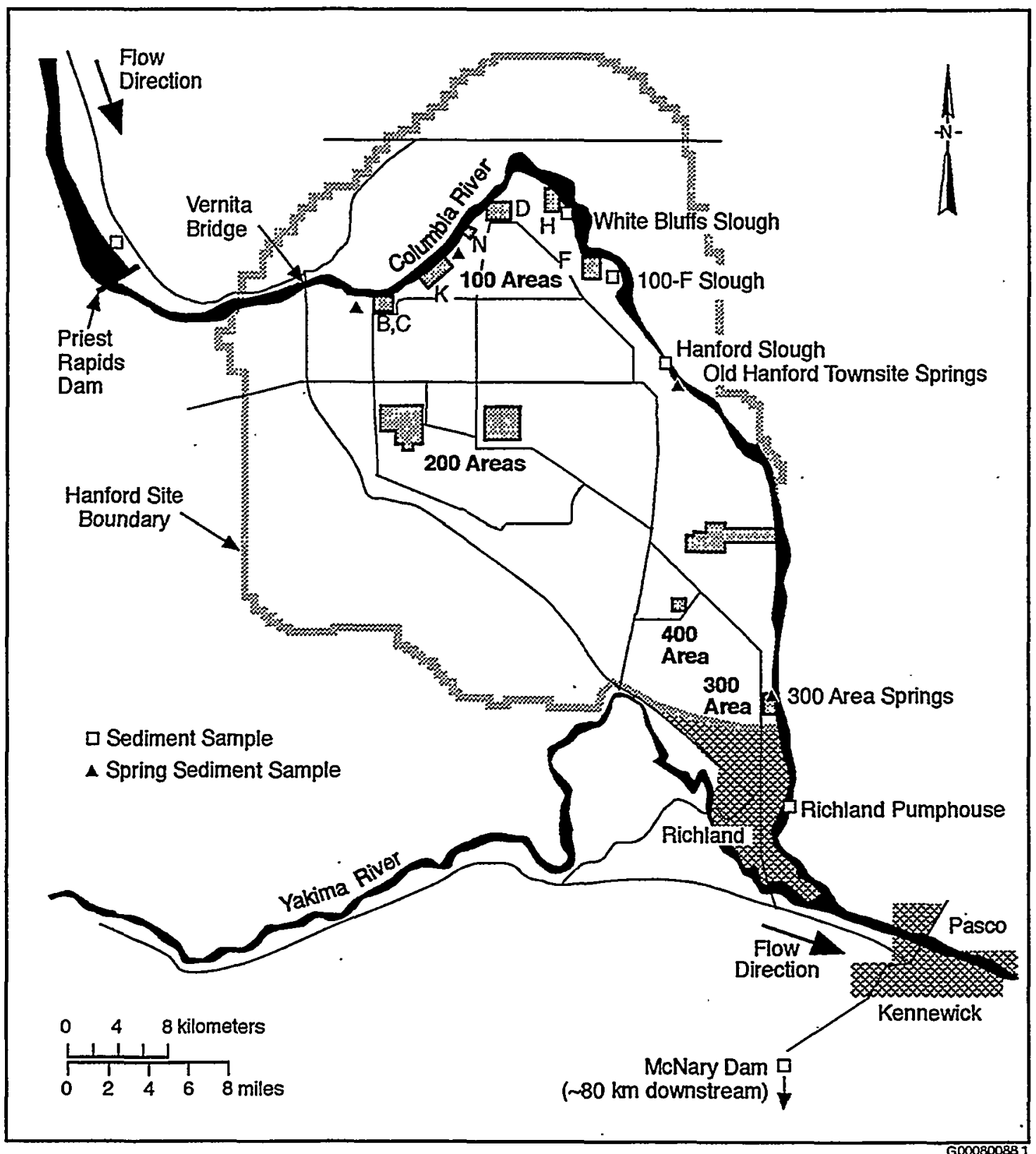

Figure III.A-5. Sampling Locations for Sediment

In addition to the routine sediment sampling, core samples are collected periodically from the upstream and downstream impoundments to determine the distribution and fate of the contaminants present as a result of past Hanford Site operations. The. frequency of this sampling is dependent on the findings of past sampling activities and in consideration of future river and/or downstream impoundment activities.

\section{Sample Collection Methods}

Because of the depth and swiftness of the river at some of the sediment sampling locations, samples are collected using a dredge-type mechanical sampler. In some cases, primarily in the shallow-water 
sloughs along the Hanford Reach, the dredge is used manually to better control the sample depth. Samples are collected according to PNL-MA-580.

\section{Analytical Methods}

Analytical methods are selected to meet the minimum goal of detecting levels equivalent to a human dose of 1 millirem EDE if that concentration were sustained for a year. An additional goal is to achieve the lower detection levels available using standard state-of-the-art analytical methods. These goals and the analysis methods and detection limits are summarized in the subsection entitled Laboratory Procedures.

\section{Quality Control Methods}

Sediment surveillance is controlled under the overall project QA and analytical control program, described in the Quality Assurance and Quality Control subsection.

\section{Reporting/Alarm Levels}

Anomalous results are flagged by computer screening of reported data as they are entered into the HEIS database. Levels for reporting to DOE have been established and are listed in the Records Management and Reporting subsection. Reporting levels are equivalent to the concentration that might lead to a dose of 1 millirem EDE to the maximally exposed individual if it were sustained for a year. This reporting level provides early indication of conditions that might eventually require reporting to DOE-HQ as specified by DOE Order 5400.5 .

\section{Exceptions}

No exceptions have been taken to "should"" statements in DOE/EH-0173T.

\section{Biota and Soil Surveillance}

This subsection details the tasks formerly known as agricultural products, vegetation and soil, and fish and wildlife. Surveillance of these media provides the baseline data to address and evaluate the occurrence of both onsite and offsite radiation and chemical contamination.

A master schedule for all routine sampling is published annually (e.g., PNNL-13109 for 2000). The resulting analytical data are reviewed individually and collectively, summarized, and published in an annual environmental monitoring report (e.g., PNNL-13230 for 1999). That report compares the trends in the monitoring data collected over the previous 5 years, and the information is used to re-evaluate sample-site selection, media to be sampled, and radionuclides that require monitoring. 
The data collected from the biota and soil surveillance activities are maintained in the HEIS, a comprehensive computer database that allows comparisons with previously collected data from the same location or from designated control sites. Maintenance of these data is important as long as accident scenarios indicate the potential for significant offsite contamination.

Biota and soil surveillance activities are outlined below.

- Agricultural products are major contributors to the economy of the Columbia Basin. The Hanford Site is surrounded by large tracts of arable land, and surveillance of agricultural products (including dairy products) grown on this land is an important element of surface environmental surveillance. Radioactivity of Hanford Site origin can reach agricultural areas by two pathways: atmospheric dispersion and application of irrigation water from the Columbia River. The Riverview area of Pasco is serviced by the Franklin County Irrigation District and the area north of Richland, designated the Horn Rapids area, is serviced by the Port of Benton pump station. Both facilities provide irrigation water that is removed from the Columbia River immediately downstream of the Hanford Site. Agricultural products are grown in downwind areas around the site perimeter and can be potentially affected by atmospheric deposition.

- Soils and vegetation at publicly accessible areas near and downwind of the site must be monitored to provide assurance to the $\mathrm{DOE}$ and the public that these media are not significantly contaminated by Hanford-originated emissions. Surveillance of soils and vegetation is designed to monitor atmospheric deposition of contaminants at offsite locations not influenced by agriculture and at onsite locations adjacent to potential sources of environmental radioactivity. Atmospheric data and modeling indicate that Hanford Site effluents can be carried offsite and deposited onto the land, where there is then the potential for accumulation. Airborne radioactive materials can be either gaseous or particulate and can originate from Hanford Site facilities or from resuspension of contaminated soil by wind.

Soils and vegetation on portions of the Columbia River shoreline bordering the Hanford Site are also monitored because they may be exposed to contaminants present in Hanford Site groundwater. Data collected from these media samples are used to maintain continuity in the environmental database in support of any possible emergency response, to compare to historical data, to evaluate trends, and to provide reassurance to the public that Hanford Site effluents do not pose a threat to public health. In many cases, there is little difference between onsite and offsite concentrations at upwind or downwind locations; however, some samples collected near onsite operational areas may have slightly elevated concentrations.

- Wildlife, on and off the site, and fish are valued natural and recreational resources. Fish in the Columbia River and game residing onsite (elk, deer, rabbits, upland game birds, and waterfowl) may move offsite and be harvested by the public for consumption. It is important, therefore, that fish and wildlife be sampled to document levels of radioactivity in the edible tissues. Hanford Site fish and wildlife may be exposed to radioactive materials from a number of sources. Fish and other aquatic life may be exposed to low levels of radionuclides present in Hanford Site groundwater entering the Columbia River via shoreline springs (i.e., 100-N Area, Old Hanford Townsite, and 300 Area). Exposure to Hanford Site effluents, unplanned releases, and releases from cleanup activities may also lead to low-level contamination of edible tissues. 
A large inventory of radioactive waste is found in the 100,200,300, and 600 Areas, and there is a potential at some of these sites for biointrusion. The collection of species with small home ranges adjacent to operating areas assists in the verification of facility controls.

Because of the potential for exposure to contaminants and the offsite migration of some animals, continued annual surveillance is considered necessary to provide reassurance to the hunting and fishing public.

Background samples are collected from distant locations, so that the contribution of Hanford-related radionuclides in wildlife tissues can be determined.

\section{Objectives}

The objectives of biota and soil surveillance are the following:

- verify that doses (through the agricultural products pathway and consumption of edible fish and wildlife) caused by Hanford Site operations remain low and quantifiable through periodic sampling as required by DOE/EH-0173T

- provide assurance to producers and consumers of agricultural products that the degree of contamination caused by site operations is known and documented in the annual Hanford Site environmental report (e.g., PNNL-13230 for 1999) and special reports as required

- provide baseline data to quantify any incremental effects of unexpected releases of radionuclides and long-term buildup of radionuclides in biota and soil

- monitor the buildup and inventory of long-lived radionuclides onsite and offsite from deposition of aqueous and airborne releases

- monitor contaminated, or potentially contaminated, areas along the Columbia River shoreline

- provide assurance to the public that the degree of contamination from Hanford Site operations is known and quantified

- evaluate radionuclides in wildlife near operational areas as indicators of biointrusion or inadvertent exposure.

\section{Plan Rationale and Criteria}

The surveillance criteria for biota and soil are based on "should*" statements found in DOE/ EH-0173T. Pathway analyses indicate that effluents of Hanford origin can reach agricultural products through atmospheric deposition at downwind locations and through irrigation with contaminated Columbia River water. Specific agricultural pathways target a variety of local, representative products identified in DOE/EH-0173T and emphasize the concern for public assurance. 
With the exception of tritium in milk, current levels of key radionuclides are at or below analytical detection limits. Assurance that regional agricultural products are not contaminated is important to the public, the region's agribusinesses, and the DOE. Therefore, periodic sampling must be done in a manner and frequency that provides the ability to estimate the contribution from site operations.

Soil and vegetation sampling supports air-monitoring efforts to document fugitive radioactive effluents that settle on the ground. Additionally, special sampling is conducted as needed to address sitecleanup actions, decommissioning, and transfer of property to other federal, state, or local agencies. This approach is consistent with guidance given in DOE/EH-0173T.

Vegetation sampling has been reduced in recent years because environmental concentrations of routinely monitored radionuclides have fallen below detection limits. Consequently, monitoring has been focused on those onsite locations that have indicated potentially elevated concentrations, on perimeter downwind locations, and on an upwind location. Special onsite vegetation sampling will emphasize sample collection along the Columbia River shoreline, aquatic vegetation in the river, and selected terrestrial location sites associated with cleanup activities.

Fish and wildlife sampling is based on the potential for consumption by hunters or fishers, the likelihood of exposure, and the possibility of accumulation of radionuclides by fish and wildlife. The species of fish and wildlife selected for sampling are found in sufficient abundance that sampling will not affect population stability. Species that may possibly be consumed as harvestable fish or wildlife are preferred; however, consideration is also given to species that have a high potential for exposure to site effluents or that may intrude into waste sites. Consideration is also given to species that may be consumed by ethnic groups.

Sampling procedures are designed to ensure that sample collection is performed in an unbiased manner. Sampling and data quality objectives are continuously reviewed, as are scheduling or media substitutions depending on availability of farm products and current interests and issues regarding agribusiness and site activities. The data from these samples are also used to support offsite dose estimates based on effluent monitoring.

\section{Media Selection}

Selection of specific media is based on their significance to human dose. Specific agricultural products are selected because they are potentially exposed to atmospheric deposition, irrigation with Columbia River water containing Hanford Site effluents, or naturally contaminated groundwater; consumed by farmers; sold commercially; or are known to contribute to a human dose through a specific pathway. The media that are routinely monitored include the following:

- milk - Whole raw milk is collected from control locations (generally upwind and distant from the Hanford Site) and from dairies closer and downwind of the site.

- farm produce - Surveillance of farm produce involves the collection of 10 samples distributed among fruit (apples, grapes, cherries), vegetables (potatoes, tomatoes), and leafy vegetables. Specific foodstuffs are collected by area (Figure III.A-6), and not all areas yield the same types of produce. 


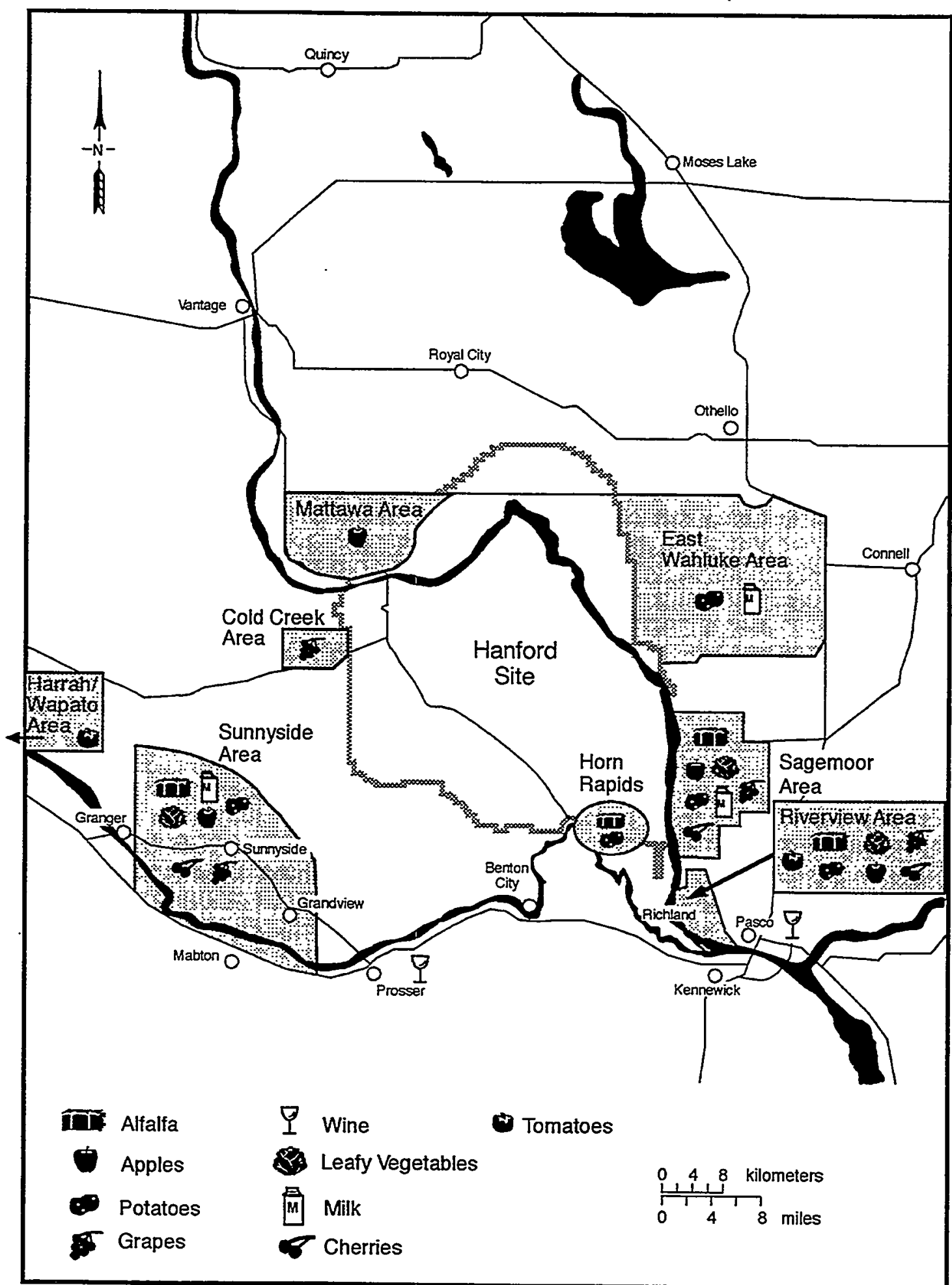

G00080088.5

Figure II.A-6. Sampling Locations for Food and Farm Products in Calendar Year 2000 
- alfalfa - Alfalfa samples are collected from one upwind control location and three locations adjacent to the Hanford Site.

- wine - Red and white varieties of wine are collected from upwind and downwind locations. Only wines that have been prepared from grapes grown in the designated sampling areas are analyzed.

- soil and vegetation - Soil samples consist of cores taken to a depth of 2.5 centimeters. Vegetation is removed before coring, and the sample is sieved before analysis at the analytical laboratory. Routine vegetation samples consist of the prevalent natural plants, usually rabbit brush and sagebrush, at the sampling locations.

- fish - Whitefish have historically been sampled because of their propensity to accumulate radionuclides; however, carp, suckers, and bass are also sampled. Two sample types are obtained: fillet, representing the edible portion; and offal, the eviscerated remnants including the head, skin, fins, and bones.

- game - The species collected include elk, deer, rabbits, geese, and upland game birds (usually pheasants or quail, but may include chukars). Resident Canada geese are sampled from the Columbia River. Muscle and bone samples are collected. If heavy metal radionuclides are analyzed, liver tissue is analyzed.

\section{Analyte Selection}

Radionuclides are selected based on monitored effluent releases, degree to which the radionuclide contributes to the dose associated with the pathway, and public and agribusiness concerns (DOE/ EH-0173T). Cleanup and other site activities that occur in the future may require analyses for specific radionuclides in biota and soil. These will be addressed on a case-by-case basis as they occur. Analytes routinely monitored for in specific media are given in a master sampling schedule (e.g., PNNL-13109 for 2000).

Agricultural products are analyzed for tritium, strontium-90, iodine-129, and gamma emitters (including cesium-137). These radionuclides are important because of their biological activity: iodine-129 concentrates in the thyroid via the milk pathway, cesium-137 is found in muscle, strontium- 90 accumulates in bone and alfalfa (compared to other crops), and tritium is usually incorporated into liquids within meat or plant material as tritiated water. Principal radionuclides associated with atmospheric fallout are monitored to partition Hanford-related effects from background and fallout. Generally, fallout radionuclides include strontium-90 and cesium-137. Last, radionuclides must have a sufficiently long half-life to pose a realistic hazard by the food-chain pathway.

Soil samples are analyzed for the radionuclides common to Hanford Site operations: gamma emitters, strontium-90, uranium-235, uranium-238, plutonium-239/240, and, for selected samples, americium-241. Vegetation samples are analyzed for gamma emitters, uranium, strontium-90, and plutonium-239/240. These radionuclides are selected because they persist in the environment, given their long half-lives, and because they are indicative of past site operations. 
Fish and wildlife samples are analyzed for strontium-90 and cesium-137. Gamma spectrometry, which is used to measure cesium-137, also measures naturally occurring beryllium-7 and potassium-40, cobalt-60, antimony-125, europium-152, europium-154, europium-155, and cesium-134. Radionuclide concentrations in wildlife during the past 10 years have indicated little need to conduct routine analyses for other radionuclides. Plutonium may be analyzed for special interests or special circumstances.

\section{Sampling Frequency}

Agricultural products are collected during the harvest season. Sampling locations that represent the potential for the highest environmental dose from Hanford Site effluents are sampled more frequently than others. Specific fruits and vegetables are sampled in alternating years or on a 3-year cycle as indicated in a master sampling schedule (e.g., PNNL-13109 for 2000). Approximately 20 milk samples are collected from several locations on a quarterly or semiannual basis.

Soil and vegetation samples are collected on a 5-year cycle, and are scheduled for collection in 2001. This cycle is adequate to detect long-term trends in environmental radioactivity. This sampling schedule is consistent with DOE/EH-0173T requirements and the change in the site's mission from production to cleanup.

Fish and wildlife are collected on a rotating schedule, as indicated in a master sampling schedule (e.g., PNNL-13109 for 2000). This collection schedule exceeds the minimum requirements of DOE/ $\mathrm{EH}-0173 \mathrm{~T}$; however, the current level of effort is consistent with meeting DOE concerns for public reassurance relative to contamination levels in fish and game in the region, emphasis on cleanup activities on the site, and recent concerns about contaminants in the Columbia River.

Fish collections have been placed on a 2- to 3-year rotating schedule, including collections at background locations. Whitefish and carp are collected in alternating years from Hanford Reach locations (in particular, the 100-N to 100-D section of the river) and at background locations every 5 years. The more frequent collection of carp and whitefish is justified because both species are bottom-feeding omnivores and are prone to accumulate radionuclides associated with benthic food chains. Bottom feeding fish generally accumulate higher levels of contaminants than do species with other feeding preferences. Bass are sampled from the $100-\mathrm{F}$ and Hanford Sloughs every 3 years because of their popularity with local fishers.

Wildlife samples are collected in alternating years, with rabbits alternating with deer or elk and pheasants alternating with geese. Wildlife populations undergo natural fluctuations, and routinely scheduled species are not always abundant or easily collected. When this occurs, the sampling and data quality objectives are reviewed and scheduling or species substitutions are considered. Offsite control wildlife are collected on a 5-year schedule. All collections of fish and wildlife are conducted under permit with the Washington State Department of Fish and Wildlife, the U.S. Fish and Wildlife Service, and PNNL's animal care committee, which oversees all PNNL activities dealing with vertebrate animals. 


\section{Sampling Location Selection}

Locations are selected to provide samples that are likely to contain the maximum offsite concentrations of radionuclides from Hanford Site-originated atmospheric and liquid effluents (see DOE/ EH-0173T). Control or background locations are upwind of the Hanford Site or are independent of the Hanford Reach and Hanford Site groundwater.

The Riverview area and the Horn Rapids area are sampled for farm products because they are the first agricultural areas located downstream of the Hanford Site that use Columbia River water for irrigation. The remaining agricultural sites are located primarily on the site perimeter in downwind locations (see Figure III.A-6).

Sites for soil and vegetation sampling are located in undisturbed areas to facilitate monitoring of long-term accumulation (Figure III.A-7). Generally, soil and vegetation samples are collected near airand external radiation-sampling locations to facilitate interpretation of results (see DOE/EH-0173T). Sampling locations along the Columbia River shoreline are selected to monitor potential public exposures to contaminated vegetation. Onsite soil- and vegetation-sample locations are selected to provide close-in monitoring of operational areas that can release radioactive materials.

Samples of fish are collected immediately adjacent to and downstream of locations where potentially contaminated spring water is known to enter the Columbia River (Figure III.A-8). Wildlife are collected from locations with the highest potential exposure to Hanford Site radioactive effluents (e.g., the 100-N Area springs). Special nonroutine analyses are anticipated for elk on the Hanford Site because the population has moved onto the central plateau and toward the Columbia River.

Background samples are collected from areas expected to receive approximately the same contribution of fallout radioactivity as is found on the Hanford Site. For fish, they are distant upstream residents that have a low probability of passing over upstream dams. Background sites for game species are distant, generally considered upwind of Hanford (e.g., Boardman, Oregon, for rabbits) and in arid environments.

\section{Sampling or Measurement Methods}

Sampling methods are described in PNL-MA-580, which also addresses sample preparation. Agricultural products are collected in a manner to ensure that adequate amounts of sample are obtained to meet analytical detection limits. Care is taken to ensure that the produce sample is not contaminated with soil.

Soil is sampled to a depth of 2.5 centimeters and a diameter of 10 centimeters with a shallow coring device ("cookie cutter") and composited to form one sample from five cores. Vegetation samples consist of the current year's growth collected from shrub species present in proportion to their estimated abundance at the sample site.

Fish and wildlife are collected by trapping, hunting, and several methods of fishing, including rod and reel, electroshocking, and seining. Disposal of animal waste is performed in accordance with state regulatory agency and PNNL waste management guidance. 


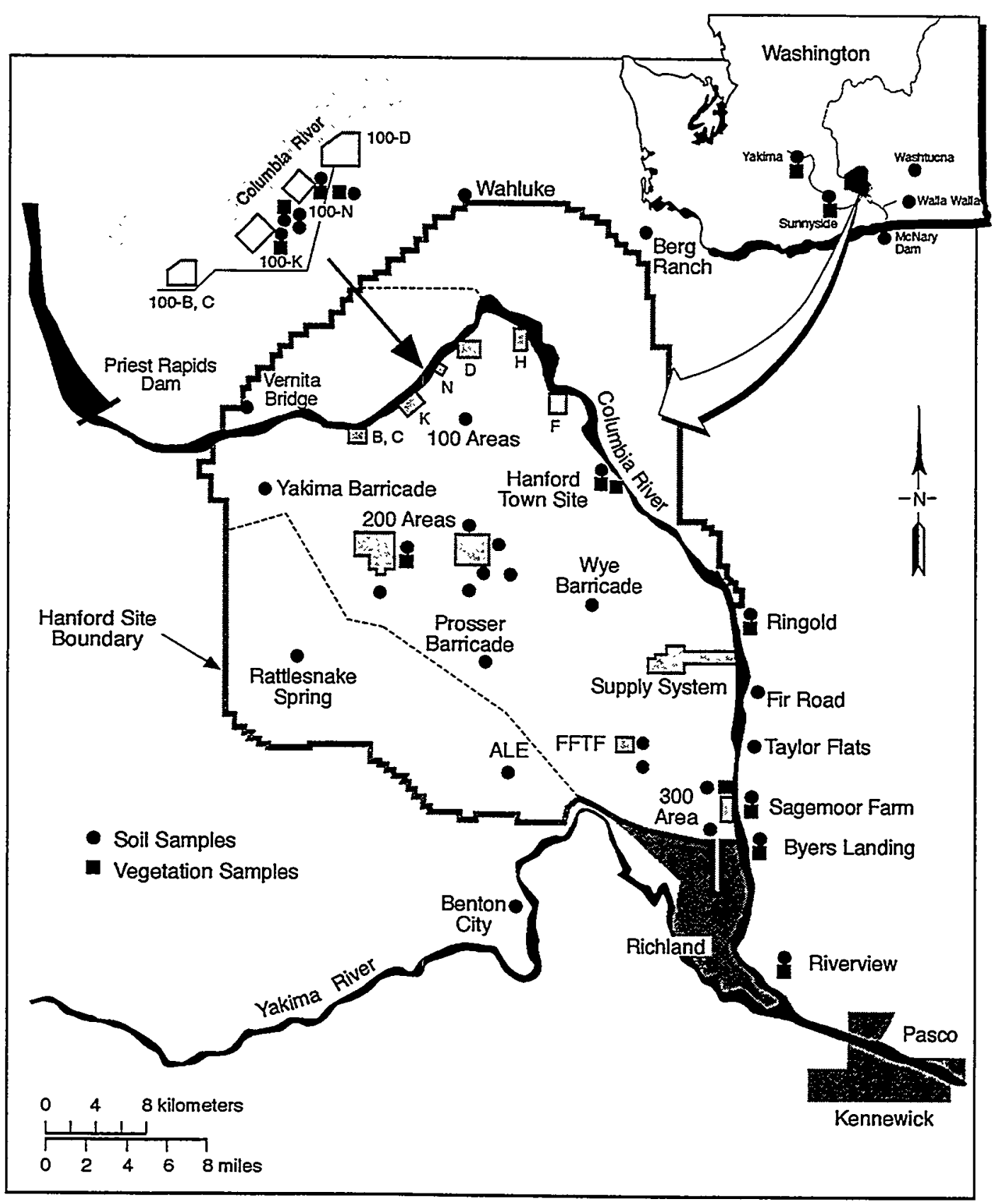

$\$ 9412049.8$

Figure III.A-7. Sampling Locations for Soil and Vegetation

\section{Sample Handling/Treatment Methods}

Perishable agricultural samples, such as milk, are stored in ice chests when collected and during transport to the analytical laboratory (see PNL-MA-580). Usually, samples are delivered to the analytical laboratory on the day of collection. If they must be stored before delivery, they are refrigerated or frozen as needed to minimize spoilage. 


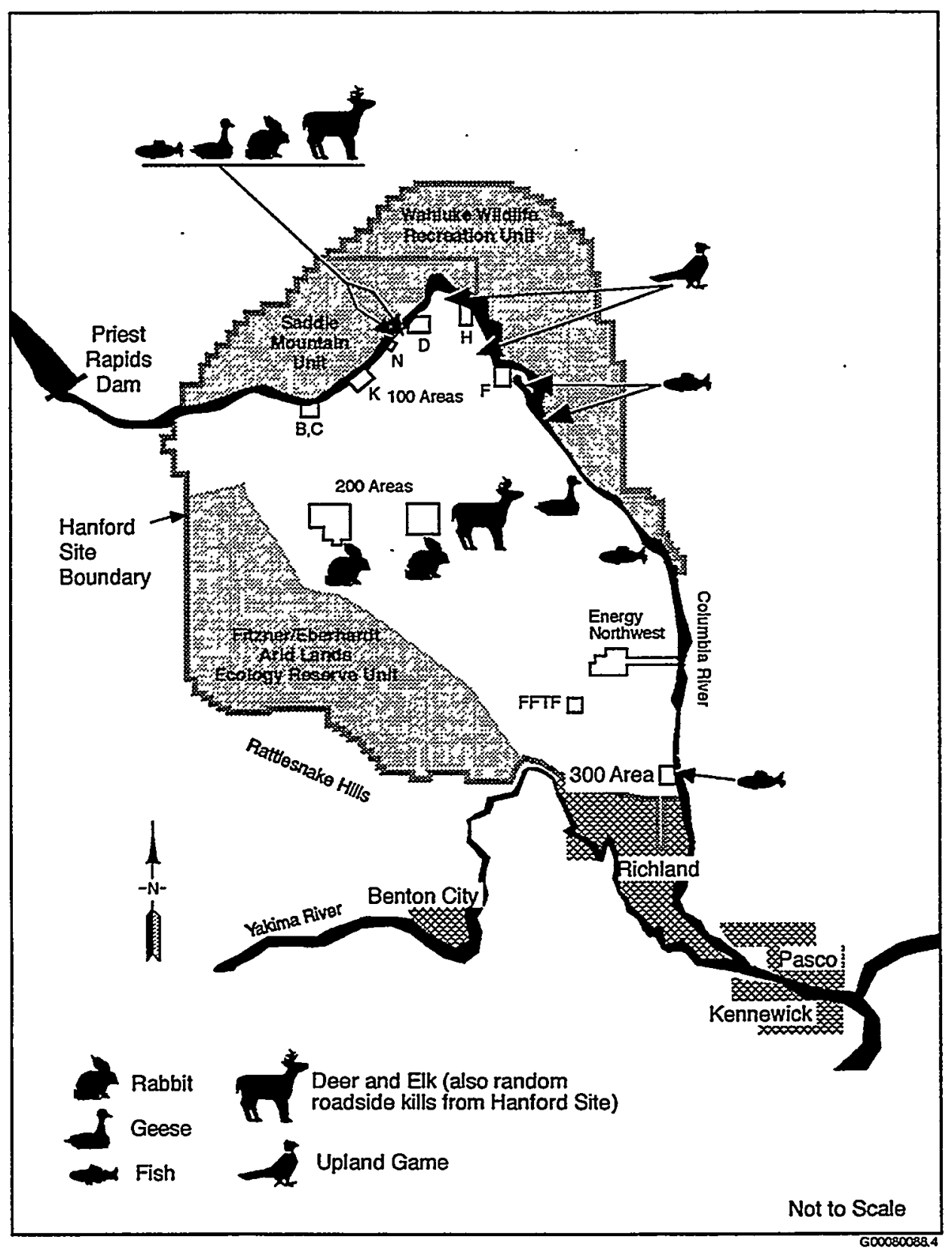

Figure III.A-8. Sampling Locations for Wildlife, Excluding Background Area

Soil and vegetation samples are double bagged when collected to minimize the potential for cross contamination. Some soil samples are taken with a "riffle splitter," producing two homogeneous subsamples that are sent to different analytical laboratories as part of a cooperative sampling program with the Washington State Department of Health.

Samples of fish and wildlife are processed to obtain bone and edible tissue. Special care is taken to ensure that flesh and organs are not contaminated by the skin or hair or by piercing the gastrointestinal tract when cleaning the animal. Whenever possible, a sample mass adequate to meet the minimum detectable concentration is collected; however, at times, sample masses are less than the required amount 
and the minimum detectable concentration increases proportionally. Tissue samples must also be kept free of dirt because background levels in the soil can lead to erroneously high values.

\section{Analytical Methods}

Analytical methods are selected to meet the minimum goal of detecting a radionuclide concentration that would yield a dose of 1 millirem EDE if that concentration were sustained in the medium and the medium were consumed for a year. An additional goal is to achieve the lower detection levels available using standard state-of-the-art analytical methods. These goals and the analysis methods are discussed in the subsection entitled Laboratory Procedures.

\section{Quality Control Methods}

Surveillance of biota and soil is controlled under the overall project QA and analytical control program described in the Quality Assurance and Quality Control subsection. Duplicate samples of selected farm products are sent to the Washington State Department of Health and/or the U.S. Food and Drug Administration for comparative analysis.

\section{Reporting/Alarm Levels}

Anomalous analytical results are flagged by computer screening as data are entered into the HEIS database. Concentrations requiring DOE notification have been established and are listed in the subsection entitled Records Management and Reporting. Reporting levels are equivalent to the concentration that might lead to a dose of 1 millirem EDE to the maximally exposed individual if it were sustained for a year. For consumable media, this is a function of the concentration in the edible portion of the medium. For soil, it is external exposure, with the exceptions of strontium-90 and cesium- 137 . Reporting levels for these radionuclides are nominally equivalent to a dose of 10 millirems if sustained for 1 year because the large natural variability in such samples makes it impractical to detect a 1-millirem difference. This reporting level provides early indication of conditions that might require reporting to DOE-HQ as required by DOE Order 5400.5.

\section{Exceptions}

No exceptions have been taken to "should" statements in DOE/EH-0173T.

\section{External Radiation Surveillance}

External radiation exposure can be produced by various sources on and around the Hanford Site. The environmental pathways through air and surface water can transport radionuclides from effluent sources (point or diffuse) to locations near the public and other biota. Many of these released radionuclides produce penetrating particles and photons (i.e., beta and gamma radiations) during decay processes in media external to an organism. These media include cloud passage, surface water, soil, sediment, and 
vegetation. Other actual or potential sources of external radiation on the Hanford Site include radio- . active waste-handling, -storage, and -processing activities and radiation-generating facilities and equipment.

Several actual or potential sources could lead to external radiation exposure of the public or onsite biota from radiation or radioactive materials. These sources include waste-process streams, waste sites, diffuse sources, and onsite transport of sources or wastes. Various radiological emergency scenarios may result in significant levels of external radiation in the environment. Because of continuing changes in site operations, and land use, the significance of each of these pathways continues to vary.

Each year, a radiological pathway analysis and exposure assessment is performed. The pathway analysis, based on effluent data, does not address existing and potential external radiation from sources such as contaminated surface sediments, soil, and waste sites. However, background and elevated levels of external radiation have been studied extensively in the Hanford Site environment (PNL-3127, PNL-7124, PNL-8789), with detection of measurable increases caused by Hanford Site operations at various onsite locations and on the Hanford Reach of the Columbia River. An aerial survey (EGG 10617-1062) confirmed most of these findings, indicating several onsite locations and locations along the Hanford Reach that have above-background gamma levels. These elevated terrestrial exposure locations are mainly to the south and west of the Columbia River (onsite operational areas) and are generally not accessible to the public for extended periods of time. The elevated radiation locations along the river, islands, and federal wildlife land of the Hanford Site are areas with access restrictions; however, the public occasionally occupies these areas for varying lengths of time. The highest exposure rate at a publicly accessible location occurs near the 100-N Area shoreline. At this location, exposure levels are approximately twice the natural terrestrial background for the area. These studies and other data indicate that Hanford operations, in recent history, have not caused detectable increased levels of offsite external radiation.

Generally, it can be expected that slight increases in offsite external exposure rates from current routine releases will be difficult, if not impossible, to detect above background using cost-effective conventional monitoring (thermoluminescent dosimeters [TLDs], survey meters).

\section{Objectives}

The objectives of external radiation monitoring are the following:

- obtain external exposure measurements for actual and potential external radiation levels at locations of actual and potential public access to support the verification that doses to the public through all potential pathways from Hanford Site operations remain low relative to standards

- provide confirmatory measurements of actual or potential increases in exposures of the public or biota to radiation or radioactive materials from nuclear operations, waste-process streams, waste sites, diffuse sources, or onsite transport of sources or waste

- obtain preoperational baseline data and environmental data near waste units scheduled for treatment and/or restoration to assess the integrated effects of individual operations 
- obtain measurements at the site perimeter and in nearby communities to provide public assurance that the degree of external radiation exposure from site operations is known

- measure onsite and offsite external radiation exposure for emergency response to accidents and provide measurements to assess the environmental effects and doses from unusual releases

- support the evaluation of the effectiveness of Hanford Site effluent controls and models for predicting the concentrations of pollutants in the environment.

\section{Plan Rationale and Criteria}

The criteria for external radiation monitoring consist of those identified as the "should" statements in DOE/EH-0173T. Any exceptions to those criteria are identified in the Exceptions discussion below. The level of surveillance and the specific criteria to meet the above objectives are described below.

The monitoring locations, measurements, methods, and frequencies for meeting external radiation surveillance objectives and criteria are given each year in the sampling schedule published for that year (e.g., PNNL-13109 for 2000). The rationale and any specific criteria for these selections are discussed below.

\section{Media Selection}

External radiation exposures are measured with consideration for the types and levels of exposure expected from the various pathway transport media and other direct radiation sources. Some of the critical environmental media or sources causing potential external radiation exposure are airborne cloud passage, immersion in surface water, vegetation (i.e., contaminated tumbleweeds), shoreline sediments, and facilities at waste-handling sites.

Most of the types of radiation causing external exposures are gamma photons and beta particles. External neutron and alpha particle exposures to the public have negligible potential. Historical data support the approach of designing the measurement methods mainly for photon sources, but pure beta emitters exist in the environment unaccompanied by gamma emitters (e.g., strontium-90). Exposure levels at publicly accessible locations are typically in a range from the natural background level to possibly two to three times greater than the natural terrestrial background.

\section{Analyte Selection}

Whole-body and skin doses from external radiation fields caused by gamma (i.e., cesium-137) and "hard" beta emitters (i.e., strontium-90) are estimated using a variety of methods.

\section{Sampling and Analysis Frequency}

Sampling frequencies are determined based on the potential for detecting elevated external radiation levels and for public exposure. Equipment limitations can be important, as in the case of the widely used TLD. The minimum detectable integrated exposure of the currently used system is $\sim 5$ milliroentgens, 
and exposure times that produce at least 15 to 20 milliroentgens are recommended for the desirable " 2 sigma" ( $95 \%$ confidence level) values. The potential for detecting external radiation levels caused by current onsite operations is insignificant at most offsite locations, as opposed to onsite locations that have variable and greater potential. Sampling frequencies for onsite surveys and TLDs require adjustments that reflect changes such as potential for loss of control of radiation and modifications in operations or transportation of radiation sources. If intermittent or sporadic operations have significant potential for elevating environmental exposures, survey frequencies are adjusted. Established communication channels with Hanford Site contractors are used to acquire current operational information.

The exchange frequency for all TLDs is quarterly because approximately this much exposure time is needed to generate statistically confident results above the limit of detection. Frequencies for TLDs in significantly elevated exposure areas such as the 100-N Area shoreline were monthly because this exposure period was long enough to provide statistically confident results and because this is an area of significance for detecting potential public exposures. The frequency has been changed to improve the statistical confidence (longer exposures), to reflect the slight decrease in exposure levels along the 100-N Area shoreline, and to make the TLD collection cost efficient. If sampling periods shorter than 1 month are needed, pressurized ionization chambers or exposure meter measurements are used.

The pressurized ionization chamber measurements are continuously taken at prevailing downwind offsite locations and at an upwind location distant from the site. "Running" average exposure rates are displayed on a liquid crystal display, and averages are collected electronically and evaluated monthly by PNNL staff. The data are plotted and posted at community-operated environmental surveillance stations for public information.

Frequencies for instrument surveys vary and are set to be approximately proportional with the potential for detecting elevated exposure to the public. Some onsite surveys, such as all waste-site and road surveys, are performed by Waste Management Federal Services of Hanford, Inc. and will be considered in establishing frequencies. Shoreline surveys are performed quarterly to coincide with TLD exchange dates for efficiency.

\section{Sampling Location Selection}

External radiation sampling locations are selected to accomplish the surveillance objectives. Several sources of information are used to help determine the potential for detecting increased exposures to the public. Some important factors that influence the determination of sampling locations are the radiation source characteristics, meteorology, geography, hydrology and sedimentation, population distribution, and recreational activities or lifestyles.

Although it appears that for public dose assessment there is little need to perform distant offsite external radiation monitoring for effects from airborne routine effluents or diffuse sources, selected sampling sites are maintained and concentrated around the local communities. There is a continual need for emergency preparedness dosimetry, confirmation of effluent controls, dose modeling, public assurance, and background monitoring. The fulfillment of these needs requires placement in strategic offsite locations that are generally upwind for the background location(s) and in population centers weighted toward prevailing wind directions (BNWL-SA-4534, BNWL-SA-4676). Because of the size of the 
Hanford Site, maximum predicted concentrations from airborne effluents are typically onsite, and sampling at these locations should continue even though the data do not indicate public exposures.

The effects of the river-transport pathway on external radiation levels have been studied because of the significant amount of radionuclides released into the Columbia River from past operations (PNL-3127). Liquid effluents from waste-water treatment, groundwater, and contaminated springs have generally continued to decrease, causing lower levels of external exposure-producing radionuclides in the Columbia River. At the same time, most of the elevated exposure areas on the shoreline and islands from radionuclides that have accumulated in the sediment have decreased because of physical decay. Although significant external exposure potential at accessible locations along the river appears to be decreasing, it is assumed that elevated radiation levels to which the public could be exposed will be detectable for many years. Because of extensive river usage by local inhabitants, exposure monitoring will continue with emphasis on characterizing potential radiation fields that may expose the public. The 100-N Area shoreline has the greatest potential for the detection of increased external exposure levels from onsite operations. A technical consideration in selecting associated sampling locations along the river is the fact that the shoreline levels change significantly with water-level fluctuations. This creates a variable when estimating a dose, based on stationary sampling points, to someone standing at the shoreline. This is addressed by intermittent exposure surveys (survey meter, pressurized ionization chamber, etc.) during seasons of recreational use. Selecting sampling locations is coordinated with water- and sediment-sampling locations for data comparability and support to the extent possible.

Before starting a new TLD sampling location, an initial survey is performed and documented to determine the natural radiation levels. Gamma spectroscopy, pressurized ionization chamber measurements, micro-rem meters, and/or soil-sample analyses are considered in initial survey characterizations. A 1989 study (PNL-7124) confirmed the importance of characterizing the radionuclides contributing external dose at sample locations. That study determined that naturally occurring higher concentrations of potassium- 40 and thorium caused some perimeter TLD results to be consistently higher than typical onsite or offsite samples.

Sampling locations for pressurized ionization chamber systems are not near large structures, in valleys, near atypical geologic strata, or at an unrepresentative altitude unless it is determined that such characteristics do not jeopardize the surveillance objective for that location.

\section{Sampling or Measurement Methods Selection}

Ambient whole-body external radiological dose integrations are currently performed using the Harshaw 8807 environmental dosimeter, which consists of two lithium fluoride (TLD-700) chips and two calcium fluoride dysprosium (TLD-200) chips (reserved for emergencies). The TLD-700 chips are preferred over others because of their relatively energy independent response, tissue equivalent atomic mass, and minimal fade when deployed for extended periods.

The pressurized ionization chamber system is used at various offsite and onsite locations to accurately measure instantaneous whole-body exposure rates from gamma photons or X-rays with energies greater than 70 thousand electronvolts. The system has computer memory capability to record average 
exposure rates over varying lengths of time and to integrate total exposures. The manufacturer's published accuracy for the system is $\pm 5 \%$ at background levels, with a range extending to 100 milliroentgens per hour.

Routine external exposure-rate surveys along the Columbia River are performed using micro-rem meters. The Bicron micro-rem meter detector utilizes a tissue equivalent organic scintillator to measure dose rate. The energy response of the micro-rem meter is approximately flat for photon energies above 40 thousand electronvolts.

Routine contamination surveys by hand-held instruments are performed using the Geiger-Müller survey meter. Geiger-Müller meters are used for measuring surface contamination levels for beta or gamma emitters; results are reported in counts per minute and used to interpret compliance with regulatory limits. Although alpha-emitting radionuclides typically do not pose significant external radiation problems, the use of portable alpha survey equipment, such as an alpha scintillation probe/meter, is required when there is a concern about isolated alpha-emitter contamination.

\section{Sample Handling/Treatment Methods}

The TLDs are collected in a manner to ensure accurate exposures by appropriately shielding them in lead containers before and after deployment. The TLDs are handled in transport with consideration for keeping them unexposed to significant external radiation fields that would generate false-positive data. Comments describing any unusual handling of TLDs or any findings that may affect TLD results are recorded on the environmental surveillance trip log. Sample collection and handling procedures are documented in PNL-MA-580.

\section{Analytical Methods}

Ambient dose is measured at TLD stations using one Harshaw 8807 environmental dosimeter. The Harshaw card is contained in a sealed plastic holder. This dosimeter provides both shallow- and deepdose measurement capability. The TLD is mounted on a plastic pipe attached to a metal post at a height of approximately 1 meter above the ground surface. The two TLD-700 chips at each site are read and averaged to determine the routine exposure (or dose). The two TLD-200 chips are read and reported only as necessary following emergency conditions.

Harshaw series 8800 automated reader systems are used to process all Hanford Site environmental dosimeters. A specific time-temperature profile processing protocol is followed for environmental dosimeters. Only the dosimetric portions of the respective TLD-200 and TLD-700 glow curves are used to calculate dose.

\section{Quality Control Methods}

The most important quality control features in this task are the calibration, maintenance, and audits of the TLD reading/recording system; calibration and maintenance of survey instruments; anomalous data-tracking system; Radiation Protection Technologist training; and procedures and records maintenance. The quality control for TLDs is established pursuant to the Standards-Based Management System (PNNL 2000). Intercomparison studies have been conducted to determine and document TLD processing 
performance. Some stations are collocated with the Washington State Department of Health TLDs for intercomparison of results. Survey instruments are calibrated to American National Standards Institute N42.17, using radiation sources and standards traceable to the National Institute of Standards and Technology. Check source tests of detection equipment are routinely performed before, during, and after (when required) surveys. The pressurized ionization chamber system is returned to the factory for calibration and maintenance periodically. The anomalous data-tracking system in the environmental database is used to perform initial screening of TLD data (discussed in the subsection entitled Quality Assurance and Quality Control).

\section{Reporting/Alarm Levels}

Anomalous TLD results are flagged by computer screening of reported data as they are entered into the project database. Investigation into an anomalous result includes, as necessary, verification of the quality of the result (sampling and analytical aspects), questioning the operators of facilities near the location with anomalous results about unusual situations, reviewing nearby air sampling results, and possibly following up with immediate portable instrument measurements and/or gamma spectroscopy. Reporting levels for TLDs and pressurized ionization chambers have not been set because these instruments are not capable of reliably detecting an annual incremental dose of 1 millirem EDE above background, and measurements of environmental media are more capable of detecting events that could lead to a 1-millirem EDE incremental external dose.

\section{Exceptions}

Neutron dose detection currently is not of concern in environmental measurements because no significant potential sources for public exposure have been identified. Facility construction, security, and distances to public access points eliminate the potential for any public exposure to significant neutron fields.

Potential submersion skin doses to members of the public are estimated from effluent data and are included in dose calculations for the EDE to members of the public. Although TLDs do perform some beta detection, potential skin dose to the public is currently not considered significant and is not reported in TLD results.

Onsite or offsite continuous gamma spectroscopy has not been used to detect environmental exposures because the cost has not been justified by current operations and effluent levels. Gamma spectroscopy has been used and is available for the characterization of photon-emitting radionuclides at various onsite and offsite locations.

Shoreline exposure measurement locations are not typically established at key water-sampling locations at the site boundary (along the Columbia River) because concentrations of radionuclides in water are routinely low enough not to cause any significant external exposure. If water sampling is performed in areas where the concentration levels are suspected to be high enough to cause external exposures, exposure measurements are made. 


\section{Dose Assessment Methods}

The radiological dose that the public potentially receives during a calendar year from Hanford Site operations is calculated in terms of the EDE. These dose quantities are given in units of millirem (mrem) (millisievert [mSv]) for individuals and in units of person-rem (person-Sv) for the collective dose received by the total population within an 80 -kilometer radius of the site.

These quantities provide a way to uniformly express the radiological dose, regardless of the type or source of radiation or the means by which it is delivered. This subsection describes how the doses are calculated.

Releases of radionuclides from Hanford Site activities are usually too low to be measured in offsite air, drinking water, and food crops. Therefore, in most cases, the dose calculations are based on measurements made at the point of release (stacks and effluent streams), and environmental concentrations are estimated from these effluent measurements by environmental transport models.

The transport of radionuclides from the release source to the point of exposure is predicted by empirical models of exposure pathways. These models calculate concentrations of radionuclides in air, water, and food. Radionuclides taken into the body by inhalation or ingestion may be distributed among different organs and retained for various times. In addition, long-lived radionuclides deposited on the ground become possible sources for long-term external exposure and uptake by agricultural products. Dietary and exposure parameters are applied to calculate radionuclide intakes and radiological doses to the public. Standardized computer programs are used to perform the calculations. These programs contain internally consistent mathematical models that use site-specific dispersion and uptake parameters. These programs are incorporated in a master code, GENII (PNL-6584), which employs the dosimetry methodology described in reports by the International Commission on Radiological Protection (1979a, $1979 \mathrm{~b}, 1980,1981 \mathrm{a}, 1981 \mathrm{~b}, 1982 \mathrm{a}, 1982 \mathrm{~b}, 1988)$. The assumptions and input data used in these calculations are described below.

\section{Types of Dose Calculations Performed}

Calculations of radiological doses to the public from radionuclides released into the environment are performed to demonstrate compliance with applicable standards and regulations.

The DOE requires that estimates of radiation exposure to the general public be in EDE terms. The EDE represents the total risk of potential health effects from radiation exposure. The adoption and use of the EDE were previously recommended by the International Commission on Radiological Protection (1977). In addition to implementing the EDE requirement for offsite population dose calculations, DOE has also adopted the biokinetic models and metabolic parameters for radionuclides given by the International Commission on Radiological Protection in 1977 for estimating radiological dose. As in the past, when concentrations of radionuclides in the environment are too low to measure, DOE specifies that the doses are to be calculated from effluent data using environmental transport and dosimetry models. 
The calculation of the EDE takes into account the long-term (50 years) internal exposure from radionuclides taken into the body during the current year. The EDE is the sum of individual committed (50 years) organ doses multiplied by weighting factors that represent the proportion of the total healtheffect risk that each organ would receive from uniform irradiation of the whole body. Internal organs may also be irradiated from external sources. The external exposure received during the current year is added to the committed internal dose to obtain the total EDE. The EDE is frequently expressed in rem (or millirem), with the corresponding value in sievert (or millisievert) in parentheses. The numerous transfer factors used for pathway and dose calculations have been documented in GENII (PNL-6584) and in PNL-3777.

The following types of radiological doses are estimated:

- "boundary" dose rate (millirem per hour and millirem per year) - The external radiological dose rates during the year in areas accessible by the general public are determined from measurements obtained near operating facilities.

- "maximally exposed individual" dose (millirem) - The maximally exposed individual is a hypothetical person living at a particular location who has a postulated lifestyle conducive to receiving higher radiological doses than other members of the public would be likely to receive. All potentially significant exposure pathways to this hypothetical individual are considered, including the following:

- inhalation of airborne radionuclides

- submersion in airborne radionuclides

- ingestion of foodstuffs contaminated by radionuclides deposited on vegetation and the ground by both airborne deposition and irrigation water drawn from the Columbia River downstream of Hanford Site discharges

- exposure to ground contaminated by both airborne deposition and irrigation water

- ingestion of fish taken from the Hanford Reach of the Columbia River

- recreation along the Hanford Reach of the Columbia River, including boating, swimming, and shoreline activities.

- 80-kilometer population doses (person-rem) - Regulatory limits have not been established for population doses. However, evaluation of the collective population doses to all residents within an 80 -kilometer radius of the Hanford Site operating areas is required by DOE Order 5400.5 . The 80 -kilometer population dose represents the summed products of the individual doses for the number of individuals involved for all potential exposure pathways. 
The pathways assigned to the maximally exposed individual are assumed to be applicable to the offsite population. Consideration is given, however, to the fraction of the offsite population actually affected by each pathway. The exposure pathways for the population are as follows:

- drinking water - The cities of Richland and Pasco obtain their municipal water directly and Kennewick indirectly from the Columbia River downstream of the Hanford Site. A total population of $\sim 70,000$ in the three cities drinks water derived from the Columbia River.

- irrigated food - Columbia River water is withdrawn for irrigation of small vegetable gardens and farms in the Riverview area of Pasco in Franklin County. Enough food is grown in this district to feed an estimated 2,000 people. Commercial crops are also irrigated by Columbia River water in the Horn Rapids area of.Benton County.

- river recreation - These activities include swimming, boating, and shoreline recreation. An estimated 125,000 people who reside within 80 kilometers of the Hanford Site are assumed to be affected by these pathways.

- fish consumption - Population doses from the consumption of fish obtained locally from the Columbia River were calculated from an estimated total annual catch of 15,000 kilograms per year (without reference to a specified human group of consumers).

\section{Data}

The data that are needed to perform dose calculations based on measured effluent releases include information on initial transport through the atmosphere or river, transfer or accumulation in terrestrial and aquatic pathways, and public exposure. By comparison, radiological dose calculations based on measured concentrations of radionuclides in food require data describing only dietary and recreational activities and exposure times. These data are discussed in the following sections.

\section{Population Distribution and Atmospheric Dispersion}

Geographic distributions of the population residing within an 80-kilometer radius of the four Hanford Site operating areas are based on 1990 Bureau of the Census data (PNL-7803). These data influence the population dose by providing estimates of the number of people exposed to radioactive effluents and their proximity to the points of release.

Atmospheric dispersion data are recalculated each year and are given in the annual Hanford Site environmental data report for that calendar year (e.g., PNNL-13230, APP. 1 for 1999). These data describe the transport and dilution of airborne radioactive material, which influences the amounts of radionuclides being transported through the air to specific locations. 


\section{Terrestrial and Aquatic Pathways}

Important parameters affecting the movement of radionuclides within potential exposure pathways, such as irrigation rates, growing periods, and holdup periods, are provided in the annual environmental report (e.g., PNNL-13230 for 1999). Certain parameters are specific to the lifestyles of either "maximally exposed" or "average" individuals.

\section{Public Exposure}

The potential offsite radiological dose is related to the extent of external exposure to or intake of radionuclides released from Hanford Site operations. Parameters describing the diet, residency, and river recreation assumed for "maximally exposed" and "average" individuals are tabulated in the annual environmental report (e.g., PNNL-13230 for 1999).

\section{Dose Calculation Documentation}

The former Hanford Environmental Dose Overview Panel had the responsibility for defining standard, documented computer codes and input parameters to be used for radiological dose calculations for the public near the Hanford Site. Only those procedures, models, and parameters previously defined by the Panel are used to calculate the radiological doses (PNL-3777). Summaries of dose calculation documentation for 1999 are shown in Tables D.5 through D.9 in PNNL-13230 and Tables Dose.1 through Dose. 8 in PNNL-13230, APP. 1.

\section{Exceptions}

No exceptions have been taken to "should" statements in DOE/EH-0173T.

\section{Dosimetry Coordination}

Dosimetry coordination is an ongoing activity that was initiated in 1975 to support DOE in developing and implementing methods for health and environmental risk assessment. DOE requires radiation dose and chemical exposure evaluations be performed whenever potential environmental exposures exist. These evaluations are typically performed by the individual Hanford Site contractors for a variety of purposes. As directed by DOE, the approach used in risk evaluations and the presentation of the results must be technically consistent across the Hanford Site and in accordance with applicable regulations and DOE Orders.

Dosimetry coordination supports DOE by assessing regulatory requirements, recommending methods for implementing those requirements, and in providing an overview function to ensure that the requirements are met in a technically defensible and consistent manner across the site. Support to develop or maintain software, databases, and other methods used to assess environmental risks is provided. In 
addition, special projects are undertaken at the request of DOE to aid in resolving risk-related issues or assessing the impact of activities that take place at the site.

\section{Support for Software, Databases, and Other Risk-Assessment Methods}

This task is designed to provide an up-to-date, technically peer-reviewed, documented set of computer codes for calculating potential radiation doses resulting from radionuclides in the environment. Staff assigned to this task are responsible for maintaining and upgrading the environmental dosimetry codes and databases that are used to assess routine and accidental releases of radionuclides to the environment from Hanford Site facilities and operations. Master copies of the computer codes and libraries are maintained in protected storage with access on a use-only basis. This includes the master files for the GENII software system (PNL-6584) and the CAP-88 code (EPA-402-B-92-001), an updated version of AIRDOS-EPA that is mandated by the EPA for use in some types of radiation dose calculations.

This task supported the production of the GENII software system, which represents the currentgeneration environmental dosimetry code developed for use at the Hanford Site. Distribution of the GENII software to Hanford Site users is provided on request, and a list of the current Hanford Site users is maintained. The code is also distributed to offsite users by the Radiation Safety Information Computational Center in Oak Ridge, Tennessee. The task logs all problem reports that are received from any GENII user and also provides information in the form of summary presentations to organizations or educational institutions regarding risk analysis methods used at the Hanford Site.

The GENII software package has been in use since 1988, and items that need updating in the code continue to be identified. As part of recent recommendations from national and international radiation protection organizations, the dosimetry models currently in use have been updated, and the revised models are expected to become part of the regulatory framework in the future. In anticipation of new regulatory requirements and to incorporate the results of other recent research in the field of environmental transport and effects of hazardous materials, cooperation is maintained with projects funded by other federal agencies to upgrade the GENII software package.

\section{Regulatory Review}

DOE Orders and other regulations that relate to the need for human health and environmental risk assessments are the focus of the regulatory review. The DOE Orders and other regulations, as well as DOE-HQ and DOE field office guidance on human health protection, are used to help outline the necessary modifications to risk-assessment methods used at the Hanford Site.

\section{Special Projects}

Issues are routinely identified by DOE that may impact the data or methods used for Hanford Site risk assessments. These issues may be technical or regulatory in nature and are investigated by the project at the request of $\mathrm{DOE}$ or other onsite contractors. 


\section{Quality Assurance}

QA is established and implemented through the Standards-Based Management System (PNNL 2000).

Independent surveillances and audits may be conducted by PNNL to ensure compliance.

\section{Exceptions}

No exceptions have been taken to "should*" statements in DOE/EH-0173T.

\section{Data Management, Analysis, and Statistical Treatment}

Described herein are the objectives for management, analysis, and statistical treatment of surface environmental surveillance data. These objectives are primarily achieved through the use of HEIS. HEIS provides computer-based access to Hanford Site environmental sample data and is used to manage the data generated by the ongoing sampling efforts conducted on and around the Hanford Site.

\section{Objectives}

Good data management, data analysis, and statistical treatment practices are essential for the production of quality results. The objectives for analyzing environmental surveillance data are the following:

- manage data in a manner that ensures their timely collection, analysis, reporting, and validation in accordance with the master sampling schedule (e.g., PNNL-13109 for 2000) and the traceability of results from scheduling to archiving in the environmental database

- estimate constituent-of-concern concentrations at each sampling and/or measurement point for each sampling and/or measurement time and estimate accuracy and precision

- compare the constituent-of-concern concentrations at each sampling and/or measurement point to previous concentrations measured at the same point to recognize changes or inconsistencies in concentration levels

- compare the constituent-of-concern concentrations at each sampling and/or measurement point to reporting limits

- compare the constituent-of-concern concentrations at individual sampling and/or measurement points to those measured at control or other points and evaluate the results of those comparisons. 


\section{Data Management Overview}

HEIS is an operational system specifically designed to effectively manage data gathered during environmental monitoring and cleanup activities at the Hanford Site. HEIS includes an integrated database and is intended to provide current and consistent data to its users. The system and its data are accessible by all Hanford Site personnel. The components of HEIS are a database, data entry screens, and tools to access the data. HEIS is implemented using current industry standards, including a UNIX operating system, an Oracle database-management system, Mircosoft Access (data entry screens), and a structured query language (reports and queries). The HEIS computer system is managed by Bechtel Hanford, Inc.

In accordance with the annual master sampling schedule (e.g., PNNL-13109 for 2000), a schedule for collecting samples is established in the database at the beginning of each calendar year. Most samples for environmental surveillance are collected on a routine basis. Sample-identification labels and chainof-custody forms are generated weekly by the database steward to facilitate sample collection. The database steward also generates laboratory composite sheets that identify individual samples to be combined to form composite samples. Analytical results are provided by the laboratories and reported in either electronic or hard-copy formats and entered into the database either electronically or manually. The database can also be used to produce various status and result reports to assist personnel in the review of data and to ensure the prompt identification of unusual results. Finally, analytical results stored in the database can be retrieved for review or for use in preparing reports (e.g., PNNL-13230 for 1999).

\section{Sample Scheduling}

The cognizant PNNL manager and staff revise the calendar year sampling schedule to meet monitoring needs each year. The sampling locations, sample types, sample analyses, and frequencies of collection are identified and documented (e.g., PNNL-13109 for 2000). In accordance with that schedule, the database steward establishes the scheduling information in the database at the beginning of each calendar year. Based on this information, the database scheduling program interrogates itself to determine when a sample must be collected. The scheduled dates are automatically recalculated, based on the collection frequency, and are updated in the computer each week as the database steward generates the sample labels and chain-of-custody forms.

When a new sampling event is identified, the appropriate scheduling information is established in the database so that collection and analyses of the sample can occur.

\section{Sample Collection}

Most samples for environmental monitoring are collected on a routine basis. Sample-identification labels and chain-of-custody forms are generated weekly by the database steward to facilitate sample collection. The sample label identifies the task code (i.e., air, water, biota, soil, sediment), HEIS sampleidentification number, collection date, and analyses required. Once the sample is collected, the sample label is attached to the sample container and the sample is delivered to the analytical laboratory. The chain-of-custody form lists the samples to be collected on a given day and also identifies the task code, 
HEIS sample-identification number, sampling location, and date of collection. The chain-of-custody form accompanies the samples to the analytical laboratory, where the samples are relinquished into the custody of laboratory personnel. Laboratory personnel retain one copy of the signed chain-of-custody form; the other copy is returned to the database steward from which a permanent record is created that verifies sample collection, delivery, and receipt by the analytical laboratory. Sample-collection and -handling procedures are contained in PNL-MA-580.

Each month, the database steward also generates composite sheets that identify individual samples to be combined to form composite samples. This information is forwarded to the analytical laboratory responsible for compiling the composite samples. On completion of the compositing process, laboratory personnel return the completed composite sheets to the database steward and they become a permanent record in the project files.

\section{Tracking Sample Collection}

The database is capable of tracking samples from the time the sample labels are produced until the sample results are entered into the database. This allows for accountability of both sample collection and sample analysis. When a sample label is generated (in the case of TLDs, when the chain-of-custody is generated), an accountability file is created for each analysis scheduled (i.e., radiochemical or chemical). After the sample is collected, the collection date, identified as Date Off on the chain-of-custody form, is entered into the database, satisfying the sample-collection portion of the accountability file.

The date the sample is submitted to the laboratory is also entered into the database. This date activates the sample-analysis-tracking feature in the accountability file (see Tracking Sample Analysis below).

\section{Reporting of Analytical Data}

Samples are analyzed for the constituents identified on the sample label, which can include radiochemical or chemical analyses. External radiation surveillance also occurs with the collection of TLDs. Results are reported in association with a 2 -sigma overall propagated uncertainty. In the case of radiochemical results, a 2-sigma counting uncertainty is also reported. Data are reported by diskette or hard copy and are entered into the database either electronically or manually.

The minimum required data that are stored in the database include the following:

- HEIS sample identification number

- sample location

- sample collection date

- analytical laboratory

- analysis

- result

- result unit

- sample volume

- comments as appropriate. 


\section{Data Validation}

As radiochemical and TLD results are entered into the database, several mathematical tests are performed to determine whether the result is within the range of the established limits. The tests and supporting data include the following:

- Test 1: Was the required detection level met?

- Test 2: Was the low limit exceeded?

- Test 3: Was the high limit exceeded?

- Statistics A: The number of results, maximum, minimum, and average of the last 10 results of the same type for this sampling location are...

- Statistics B: The number of results, maximum, minimum, and average of results for this same type at all locations for the previous 12 months are...

As data are collected, the results are compared to previous results to help identify unusual measurements that require investigation or further statistical evaluation. If the result is unusual and fails any of the above tests, it is considered an anomaly and a 1-page anomalous data report is generated.

Outliers can represent a true extreme value or can indicate errors in sample collection, preparation, measurement, or equipment malfunctions. On request, the analytical laboratory will perform a data recheck, recount, or reanalysis to assist the task leader in determining the value of a questionable result. Following these investigations, the task leader, with the approval of the project manager, decides how to handle the suspect data. These decisions are documented on the anomalous data report, which becomes a permanent record in the project files.

\section{Tracking Sample Analysis}

To aid in the tracking of sample analyses, a maximum turnaround for reporting of results is established with the analytical laboratories. This turnaround, coupled with the sample submit date, provides an estimated due date for each analytical test ordered. If no result has been reported by the estimated due date, the database steward can generate a "late results" report. An outstanding result will continue to appear on the late results report until the result is received and the accountability record has been completely satisfied.

\section{Data Retrieval}

One of the primary reasons for using a data-management system is to store data and provide efficient and easy access to the thousands of analytical results recorded each year. The database contains analytical data back to 1971, which can be retrieved by using Microsoft Access software. 


\section{Database Security}

HEIS uses several techniques to prevent the loss of data because of fire, power failure, or other causes. Auto-archiving has been implemented to capture all changes to the database. The archive file can be used to recover from failures that may occur during operational hours. A nightly backup of HEIS is performed by the Bechtel Hanford, Inc. computer systems manager. Quarterly, a backup is stored offsite. In the event of a major system failure, a backup system would be available within 24 hours after shutdown.

\section{Quality Assurance}

Records of data and other information developed during the operation of the HEIS are controlled and managed in compliance with the requirements in the PNNL QA plan, which conforms to the requirements of DOE Order 414.1A and 10 CFR 830.120 as interpreted and implemented by the Standards-Based Management System (PNNL 2000). HEIS database integrity is ensured through the use of rules and constraints implemented directly by the database (refer to BHI-EE-09 regarding HEIS software control).

\section{Data Analysis and Statistical Treatment}

Analytical results are reported and recorded with estimates of their uncertainty. Data sets are not truncated and include negative numbers. The database contains the same number of significant figures reported by the analytical laboratories, but summaries and reports may only include the appropriate number of significant figures. Results are reported as less than the estimated quantitative detection limit.

Data contained in the database vary in sample type (i.e., air, water, biota, soil, sediment, TLDs), and any subset of data of a given sample type may or may not fit probability distributions typical of that type for a variety of potential reasons (e.g., sample size, mixed populations). Therefore, routine statistical summaries obtained from the database are normally based on the arithmetic mean or median as measures of central tendency and on the range, standard deviation, and standard error of the mean as measures of dispersion.

Statistical tests to determine differences and effects are based on parametric or nonparametric tests appropriate to the sample sizes, distributions of the particular data sets being tested, and hypothesis being tested.

Tests for precision and accuracy are addressed in the subsection entitled Quality Assurance and Quality Control.

\section{Exceptions}

No exceptions have been taken to "should"" statements in DOE/EH-0173T. 


\section{Laboratory Procedures}

All routine environmental surveillance samples are analyzed according to written analytical procedures. These procedures are described in general terms in this subsection and in detail in the Severn Trent Laboratory, Richland procedures manual and in PNNL department-specific procedures manuals. Contractual minimum detectable concentrations and contract-required detection limits for the various matrix/analysis combinations and other analytical information are shown in Table III.A-1 for radiological analytes and in Table III.A-2 for chemical constituents. In practice, actual minimum detectable concentrations and method detection limits have historically been significantly lower for most analyses.

\section{Air Samples}

Alpha- and beta-emitting radionuclides are measured by a direct count from the glass fiber filter (greater than $99 \%$ efficient for $0.3-\mu \mathrm{m}$ particles). Alpha radiation is counted on a low-background, gasflow proportional counter; beta radiation is counted on a gas-flow proportional counter.

Gamma-emitting radionuclides are counted directly from glass fiber filters using lithium-ion drifted germanium (Ge[Li]) or hyperpure germanium (HPGE) detectors with a multichannel, pulse-height analyzer. Listed below are the radionuclides that are reported for detectable concentrations (i.e., when net counts exceed the 2-sigma total propagated analytical uncertainty):

\begin{tabular}{|c|c|c|c|}
\hline Beryllium $-7^{(\mathrm{a})}$ & Cobalt-50 & Ruthenium-106 & Cerium-140 \\
\hline Sodium-22 & Cobalt- $60^{(a)}$ & Antimony-125 $5^{(a)}$ & Cerium/Praseodymium-144 \\
\hline Sodium-24 & Zinc-65 & Iodine-131 & Europium-152 \\
\hline Potassium $-40^{(\mathrm{a})}$ & Zirconium/Niobium-95 & Cesium-134(a) & Europium-154 ${ }^{(a)}$ \\
\hline Manganese-54 & Molybdenum-99 & Cesium-137 (a) & Europium-155 \\
\hline Iron-59 & Ruthenium-103 & Barium/Lanthanum-140 & \\
\hline
\end{tabular}

(a) Routinely reported for all samples.

Strontium-90 is leached from glass fiber filters with fuming nitric acid, scavenged with barium chromate, and ammonium hydroxide, precipitated as a carbonate, transferred to a stainless steel planchet, and counted with a low-background, gas flow proportional counter. After 15 days, the strontium-90 decay product is separated and counted with a proportional counter.

Uranium is leached from glass fiber filters with nitric acid, converted to the chloride form, and loaded onto an anion-exchange column. The effluent is then polonium decontaminated with ascorbic acid and copper disk treatment. The uranium is then extracted with anhydrous ether. The sample is then electrodeposited onto a stainless steel planchet and counted with an alpha spectrometer to determine the uranium isotopic concentrations. 
Table II.A-1. Radiological Monitoring Sampling Summary

\begin{tabular}{|c|c|c|}
\hline Type of Analysis & $\begin{array}{l}\text { Approximate Sample } \\
\text { Size Submitted }\end{array}$ & $\begin{array}{c}\text { Minimum Detectable } \\
\text { Concentration }\end{array}$ \\
\hline \multicolumn{3}{|l|}{ Air } \\
\hline Gross alpha & $800 \mathrm{~m}^{3}$ & $0.001 \mathrm{pCi} / \mathrm{m}^{3}$ \\
\hline Gross beta & $800 \mathrm{~m}^{3}$ & $0.003 \mathrm{pCi} / \mathrm{m}^{3}$ \\
\hline $\mathrm{HTO}^{(\mathrm{a})}$ & $10 \mathrm{~m}^{3}$ & $3 \mathrm{pCi} / \mathrm{m}^{3}$ \\
\hline${ }^{90} \mathrm{Sr}$ & $1,500 \mathrm{~m}^{3}$ & $0.0001 \mathrm{pCi} / \mathrm{m}^{3}$ \\
\hline${ }^{129} \mathrm{~T}^{(\mathrm{b})}$ & $1,500 \mathrm{~m}^{3}$ & $0.00001 \mathrm{pCi} / \mathrm{m}^{3}$ \\
\hline${ }^{131} \mathrm{I}$ & $800 \mathrm{~m}^{3}$ & $0.01 \mathrm{pCi} / \mathrm{m}^{3}$ \\
\hline Gamma scan $\left({ }^{137} \mathrm{Cs}\right)$ & $1,500 \mathrm{~m}^{3}$ & $0.01 \mathrm{pCi} / \mathrm{m}^{3}$ \\
\hline $\mathrm{Pu}$ (isotopic) & $1,500 \mathrm{~m}^{3}$ & $0.000005 \mathrm{pCi} / \mathrm{m}^{3}$ \\
\hline${ }^{241} \mathrm{Am}^{(\mathrm{c})}$ & $1,500 \mathrm{~m}^{3}$ & $0.00005 \mathrm{pCi} / \mathrm{m}^{3}$ \\
\hline $\mathrm{U}$ (isotopic) & $1,500 \mathrm{~m}^{3}$ & $0.00005 \mathrm{pCi} / \mathrm{m}^{3}$ \\
\hline \multicolumn{3}{|l|}{ River and Surface Water } \\
\hline Gross alpha & $500 \mathrm{~mL}$ & $4.0 \mathrm{pCi} / \mathrm{L}$ \\
\hline Gross beta & $500 \mathrm{~mL}$ & $4.0 \mathrm{pCi} / \mathrm{L}$ \\
\hline${ }^{3} \mathrm{H}$ (lo) & $500 \mathrm{~mL}$ & $10 \mathrm{pCi} / \mathrm{L}$ \\
\hline${ }^{3} \mathrm{H}$ & $100 \mathrm{~mL}$ & $300 \mathrm{pCi} / \mathrm{L}$ \\
\hline${ }^{89} \mathrm{SI}^{(\mathrm{d})}$ & $10 \mathrm{~L}$ & $0.6 \mathrm{pCi} / \mathrm{L}$ \\
\hline${ }^{90} \mathrm{Sr}$ & $10 \mathrm{~L}$ & $0.06 \mathrm{pCi} / \mathrm{L}$ \\
\hline${ }^{99} \mathrm{Tc}$ & $4 \mathrm{~L}$ & $1.0 \mathrm{pCi} / \mathrm{L}$ \\
\hline${ }^{129} \mathrm{I}$ & $6 \mathrm{~L}$ & $0.000001 \mathrm{pCi} / \mathrm{L}$ \\
\hline Gamma scan $\left({ }^{137} \mathrm{Cs}\right)$ & $1,000 \mathrm{~L}$ water equivalent & $0.01 \mathrm{pCi} / \mathrm{L}$ \\
\hline Gamma scan $\left({ }^{137} \mathrm{Cs}\right)$ & $4 \mathrm{~L}$ & $6.0 \mathrm{pCi} / \mathrm{L}$ \\
\hline $\mathrm{Pu}$ (isotopic) & $6,000 \mathrm{~L}$ water equivalent & $0.0002 \mathrm{pCi} / \mathrm{L}$ \\
\hline U (isotopic) & $1 \mathrm{~L}$ & $0.06 \mathrm{pCi} / \mathrm{L}$ \\
\hline \multicolumn{3}{|l|}{ Milk } \\
\hline${ }^{3} \mathrm{H}$ & $100 \mathrm{~mL}$ & $300 \mathrm{pCi} / \mathrm{L}$ \\
\hline${ }^{90} \mathrm{Sr}$ & $1 \mathrm{~L}$ & $2.0 \mathrm{pCi} / \mathrm{L}$ \\
\hline${ }^{129} \mathrm{~T}$ & $4 \mathrm{~L}$ & $0.00001 \mathrm{pCi} / \mathrm{L}$ \\
\hline${ }^{131} \mathrm{I}$ & $4 \mathrm{~L}$ & $0.5 \mathrm{pCi} / \mathrm{L}$ \\
\hline Garmma scan $\left({ }^{137} \mathrm{Cs}\right)$ & $1 \mathrm{~L}$ & $8 \mathrm{pCi} / \mathrm{L}$ \\
\hline \multicolumn{3}{|l|}{ Fruit } \\
\hline${ }^{3} \mathrm{H}$ & $2 \mathrm{~kg}$ & $300 \mathrm{pCi} / \mathrm{L}$ \\
\hline${ }^{90} \mathrm{Sr}$ & $150 \mathrm{~g}$ & $0.005 \mathrm{pCi} / \mathrm{L}$ \\
\hline${ }^{129} \mathrm{I}$ & $100 \mathrm{~g}$ & $1.0 \mathrm{pCi} / \mathrm{L}$ \\
\hline Gamma scan $\left({ }^{137} \mathrm{Cs}\right)$ & $850 \mathrm{~g}$ & $0.02 \mathrm{pCi} / L$ \\
\hline $\mathrm{Pu}$ (isotopic) & $150 \mathrm{~g}$ & $0.0004 \mathrm{pCi} / \mathrm{L}$ \\
\hline
\end{tabular}


Table III.A-1. (contd)

\begin{tabular}{|c|c|c|}
\hline Type of Analysis & $\begin{array}{l}\text { Approximate Sample } \\
\text { Size Submitted }\end{array}$ & $\begin{array}{c}\text { Minimum Detectable } \\
\text { Concentration }\end{array}$ \\
\hline \multicolumn{3}{|c|}{ Produce and Farm Products } \\
\hline${ }^{90} \mathrm{Sr}$ & $150 \mathrm{~g}$ & $0.005 \mathrm{pCi} / \mathrm{L}$ \\
\hline${ }^{99} \mathrm{Tc}$ & $100 \mathrm{~g}$ & $1.0 \mathrm{pCi} / \mathrm{L}$ \\
\hline Gamma scan $\left({ }^{137} \mathrm{Cs}\right)$ & $850 \mathrm{~g}$ & $0.02 \mathrm{pCi} / \mathrm{L}$ \\
\hline${ }^{239 / 240} \mathrm{Pu}$ & $150 \mathrm{~g}$ & $0.0004 \mathrm{pCi} / \mathrm{L}$ \\
\hline U (isotopic) & $100 \mathrm{~g}$ & $0.02 \mathrm{pCi} / \mathrm{L}$ \\
\hline \multicolumn{3}{|l|}{ Beef } \\
\hline${ }^{90} \mathrm{Sr}$ & $150 \mathrm{~g}$ & $0.05 \mathrm{pCi} / \mathrm{L}$ \\
\hline Gamma scan $\left({ }^{137} \mathrm{Cs}\right)$ & $600 \mathrm{~g}$ & $0.02 \mathrm{pCi} / \mathrm{L}$ \\
\hline \multicolumn{3}{|l|}{ Poultry } \\
\hline${ }^{90} \mathrm{~S}$ & $150 \mathrm{~g}$ (muscle) & $0.005 \mathrm{pCi} / \mathrm{L}$ \\
\hline Gamma scan $\left({ }^{137} \mathrm{Cs}\right)$ & $600 \mathrm{~g}$ (muscle) & $0.02 \mathrm{pCi} / \mathrm{L}$ \\
\hline \multicolumn{3}{|l|}{ Eggs (without shells) } \\
\hline${ }^{90} \mathrm{Sr}$ & $150 \mathrm{~g}$ & $0.005 \mathrm{pCi} / \mathrm{L}$ \\
\hline Gamma scan $\left({ }^{137} \mathrm{Cs}\right)$ & $600 \mathrm{~g}$ & $0.02 \mathrm{pCi} / \mathrm{L}$ \\
\hline \multicolumn{3}{|l|}{ Wine } \\
\hline${ }^{3} \mathrm{H}$ & $500 \mathrm{~mL}$ & $10 \mathrm{pCi} / \mathrm{L}$ \\
\hline Gamma scan $\left({ }^{137} \mathrm{Cs}\right)$ & $1 \mathrm{~L}$ & $6.0 \mathrm{pCi} / \mathrm{L}$ \\
\hline \multicolumn{3}{|l|}{ Fish Fillet } \\
\hline${ }^{90} \mathrm{Sr}$ & $150 \mathrm{~g}$ & $0.05 \mathrm{pCi} / \mathrm{L}$ \\
\hline${ }^{99} \mathrm{Tc}$ & $100 \mathrm{~g}$ & $1.0 \mathrm{pCi} / \mathrm{L}$ \\
\hline Gamma scan $\left({ }^{137} \mathrm{Cs}\right)$ & $600 \mathrm{~g}$ & $0.02 \mathrm{pCi} / \mathrm{L}$ \\
\hline $\mathrm{U}$ (isotopic) & $100 \mathrm{~g}$ & $0.02 \mathrm{pCi} / \mathrm{L}$ \\
\hline \multicolumn{3}{|l|}{ Fish Carcass } \\
\hline${ }^{90} \mathrm{Sr}$ & $150 \mathrm{~g}$ & $0.05 \mathrm{pCi} / \mathrm{L}$ \\
\hline Gamma scan $\left({ }^{137} \mathrm{Cs}\right)$ & $600 \mathrm{~g}$ & $0.02 \mathrm{pCi} / \mathrm{L}$ \\
\hline \multicolumn{3}{|l|}{ Geese and Game Birds } \\
\hline${ }^{90} \mathrm{Sr}$ & $150 \mathrm{~g}$ (bone) & $0.05 \mathrm{pCi} / \mathrm{L}$ \\
\hline${ }^{99} \mathrm{Tc}$ & $100 \mathrm{~g}$ (muscle) & $1.0 \mathrm{pCi} / \mathrm{L}$ \\
\hline Gamma scan $\left({ }^{137} \mathrm{Cs}\right)$ & $600 \mathrm{~g}$ (muscle) & $0.02 \mathrm{pCi} / \mathrm{L}$ \\
\hline $\mathrm{Pu}$ (isotopic) & $100 \mathrm{~g}$ (liver) & $0.0004 \mathrm{pCi} / \mathrm{L}$ \\
\hline U (isotopic) & $100 \mathrm{~g}$ (muscle) & $0.02 \mathrm{pCi} / \mathrm{L}$ \\
\hline
\end{tabular}


Table III.A-1. (contd)

\begin{tabular}{|c|c|c|}
\hline Type of Analysis & $\begin{array}{l}\text { Approximate Sample } \\
\text { Size Submitted }\end{array}$ & $\begin{array}{l}\text { Minimum Detectable } \\
\text { Concentration }\end{array}$ \\
\hline \multicolumn{3}{|l|}{ Deer } \\
\hline Gamma scan $\left({ }^{137} \mathrm{Cs}\right)$ & $600 \mathrm{~g}$ (muscle) & $0.02 \mathrm{pCi} / \mathrm{L}$ \\
\hline${ }^{90} \mathrm{Sr}$ & $150 \mathrm{~g}$ (bone) & $0.05 \mathrm{pCi} / \mathrm{L}$ \\
\hline $\mathrm{Pu}$ (isotopic) & $100 \mathrm{~g}$ (liver) & $0.0004 \mathrm{pCi} / \mathrm{L}$ \\
\hline \multicolumn{3}{|l|}{ Rabbits } \\
\hline${ }^{90} \mathrm{Sr}$ & $150 \mathrm{~g}$ (bone) & $0.05 \mathrm{pCi} / \mathrm{L}$ \\
\hline Gamma scan $\left({ }^{137} \mathrm{Cs}\right)$ & $600 \mathrm{~g}$ (muscle) & $0.02 \mathrm{pCi} / \mathrm{L}$ \\
\hline $\mathrm{Pu}$ (isotopic) & $100 \mathrm{~g}$ (liver) & $0.0004 \mathrm{pCi} / \mathrm{L}$ \\
\hline \multicolumn{3}{|l|}{ Soil and Sediment } \\
\hline${ }^{90} \mathrm{Sr}$ & $150 \mathrm{~g}$ & $0.05 \mathrm{pCi} / \mathrm{L}$ \\
\hline Gamma scan $\left({ }^{137} \mathrm{Cs}\right)$ & $850 \mathrm{~g}$ & $0.02 \mathrm{pCi} / \mathrm{L}$ \\
\hline $\mathrm{Pu}$ (isotopic) & $150 \mathrm{~g}$ & $0.0006 \mathrm{pCi} / \mathrm{L}$ \\
\hline U (isotopic) & $100 \mathrm{~g}$ & $0.02 \mathrm{pCi} / \mathrm{L}$ \\
\hline \multicolumn{3}{|l|}{ Native Vegetation } \\
\hline Gamma scan $\left({ }^{137} \mathrm{Cs}\right)$ & $850 \mathrm{~g}$ & $0.02 \mathrm{pCi} / \mathrm{L}$ \\
\hline${ }^{90} \mathrm{Sr}$ & $130 \mathrm{~g}$ & $0.05 \mathrm{pCi} / \mathrm{L}$ \\
\hline $\mathrm{Pu}$ (isotopic) & $130 \mathrm{~g}$ & $0.0004 \mathrm{pCi} / \mathrm{L}$ \\
\hline$U$ (isotopic) & $100 \mathrm{~g}$ & $0.02 \mathrm{pCi} / \mathrm{L}$ \\
\hline \multicolumn{3}{|l|}{ Direct Radiation Exposure } \\
\hline Thermoluminescent dosimeter & 4 chips per holder & $1.0 \mathrm{mR}$ \\
\hline $\begin{array}{l}\text { (a) Tritiated water vapor. } \\
\text { (b) Four locations. } \\
\text { (c) Not routinely analyzed for. } \\
\text { (d) Absolute sensitivity in the }\end{array}$ & -it is unad is wall holow & \\
\hline
\end{tabular}

Plutonium is leached from glass fiber filters with nitric acid and passed through an anion-exchange resin. The plutonium on the resin column is eluted with hydrochloric acid containing ammonium iodide, electrodeposited on a stainless steel disk, and then counted with an alpha spectrometer to determine the plutonium-238 and plutonium-239/240 concentrations.

Americium-241 concentrations are determined through the use of the eluate from the plutonium anion-exchange resin column. A calcium oxalate precipitation is performed. The americium is then extracted with dibutyl N,N-diethylcarbamylphosphate (DDCP) and passed through a cation-exchange resin column to remove iron and thorium. The americium is eluted from the resin with highconcentration hydrochloric acid, electrodeposited on a stainless steel disk, and then counted by alpha spectrometry. 
Table III.A-2. Chemical Monitoring Sampling Summary

\begin{tabular}{|c|c|c|}
\hline \multirow[b]{2}{*}{ Constituent } & \multicolumn{2}{|c|}{ Contract-Required Detection Limit } \\
\hline & Water, $\mu \mathrm{g} / \mathrm{L}$ & Solids, $\mu \mathrm{g} / \mathrm{kg}$ \\
\hline \multicolumn{3}{|l|}{ Metals } \\
\hline Antimony & 0.02 & 10,000 \\
\hline Arsenic & 0.05 & 500 \\
\hline Beryllium & 0.1 & 200 \\
\hline Cadmium & 0.01 & 500 \\
\hline Chromium & 0.2 & 1,000 \\
\hline Copper & 0.1 & 2,000 \\
\hline Lead & 0.02 & 30 \\
\hline Mercury & 0.2 & 400 \\
\hline Nickel & 0.1 & 2,500 \\
\hline Selenium & 0.5 & 500 \\
\hline Silver & 0.05 & 1,000 \\
\hline Thallium & 0.02 & 500 \\
\hline Zinc & 0.3 & 1,000 \\
\hline \multicolumn{3}{|l|}{ Anions $^{(\mathbf{a})}$} \\
\hline Chloride & 200 & \\
\hline Fluoride & 100 & \\
\hline Sulfate & 500 & \\
\hline Nitrite & 20 & \\
\hline Nitrate & 20 & \\
\hline \multicolumn{3}{|l|}{ Volatile Organic Cọpounds ${ }^{(\mathfrak{b})}$} \\
\hline Acetone & 5 & \\
\hline Benzene & 5 & \\
\hline Carbon tetrachloride & 5 & \\
\hline Chloroform & 5 & \\
\hline p-Dichlorobenzene & 5 & \\
\hline 1,1-Dichloroethane & 5 & \\
\hline 1,2-Dichloroethane & 5 & \\
\hline 1,2-Dichloroethlene (cis and trans) & 5 & \\
\hline Methylene chloride & 5 & \\
\hline 2-Butanone & 5 & \\
\hline 4-Methyl-2-pentanone & 5 & \\
\hline Tetrachloroethlene & 5 & \\
\hline Toluene & 5 & \\
\hline 1,1,1-Trichloroethane & 5 & \\
\hline
\end{tabular}


Table III.A-2. (contd)

\begin{tabular}{lcc}
\multicolumn{1}{c}{ Constituent } & & \multicolumn{2}{c}{ Contract-Required Detection Limit } \\
\cline { 1 - 1 } 1,1,2-Trichloroethane & & 5 \\
Trichloroethlene & 5 & Solids, $\mu \mathrm{g} / \mathrm{kg}$ \\
Vinyl chloride & 5 & \\
Total xylene & 5 \\
1-Butanol & 5 \\
Propionitrile & 5 \\
Carbon disulfide & 5
\end{tabular}

(a) Method 300.0 (EPA-600/4-79-020).

(b) Method 8260 (SW-846).

Tritium is collected as tritiated water vapor using silica gel. The water vapor is removed from the gel by heat and vacuum action, and then collected in a freeze trap. The tritium content of the water vapor is determined with a liquid scintillation spectrometer.

Iodine-131 is collected on triethylene-di-amine (TEDA) treated, activated charcoal ( $90 \%$ and $70 \%$ efficient for methyl iodine at 2.6 and 5.2 cubic meters per hour, respectively) and then counted on either a $\mathrm{Ge}(\mathrm{Li})$ or HPGE detector with a multichannel, pulse-height analyzer.

Iodine-129 is collected on a special petroleum-based charcoal. Iodine is removed from the charcoal, purified, and determined by mass spectrometry.

\section{Water Samples}

Samples containing alpha-emitting radionuclides (americium, neptunium, plutonium, and uranium) are treated with nitric acid and dried according to the methods given in SW-846. The residue is secured on a stainless steel planchet using a collodion solution and counted with a low-background, gas-flow proportional counter.

Beta-emitting radionuclide samples are dried in the same way as the alpha-emitting radionuclides, and are then counted directly using a gas-flow proportional counter.

Gamma-emitting radionuclides are counted directly from 500 milliliters of sample concentrate using either a $\mathrm{Ge}(\mathrm{Li})$ or HPGE detector with a multichannel, pulse-height analyzer. See air samples discussion for a list of radionuclides included in gamma scan analysis.

Strontium-90 in large-volume water samples is measured in the same manner as in air samples, but the sample is acidified and boiled down, neutralized with ammonium hydroxide, and precipitated as the carbonate before exposure to fuming nitric acid. 
Technetium-99 concentrations are determined using technetium separation by iron hydroxide precipitation followed by a carbonate precipitation. Further purification from interfering nuclides is performed by anion-exchange resin separation. The technetium-99 is counted by liquid scintillation spectrometry.

Tritium samples can be counted directly with a liquid scintillation spectrometer, or the sample can be enriched by alkaline electrolysis and then counted with a liquid scintillation spectrometer.

Uranium in the water sample is adsorbed onto anion resin following wet ashing, purified, electrodeposited onto a stainless-steel planchet, and then counted with an alpha spectrometer to determine uranium isotopic concentrations.

Filter-resin samples are analyzed for gamma-emitting radionuclides using either a $\mathrm{Ge}(\mathrm{Li})$ or HPGE detector with a multichannel, gamma-ray spectrometer. Aliquots of the resin samples are analyzed by chemical separation and alpha spectrometry for plutonium.

Iodine-129 analysis in water is determined by oxidation of the sample to "trap" the iodine on a charcoal absorber. The iodine is further processed and separated, loaded onto a thermal ionization mass spectrometer triple filament assembly, and counted on the mass spectrometer for iodine isotopic concentrations.

Volatile organic compounds are determined by SW-846 Methods $8010 / 8020,8240,8260$, or equivalent. Volatile compounds are introduced in the gas chromatograph by the purge-and-trap method. The components may then be further separated via the gas chromatograph and detected using a mass spectrometer.

For the determination of metals, samples are first digested in nitric acid. Some metals are determined by inductively coupled plasma/mass spectrometry (ICP/MS) and others by graphite furnace atomic absorption (GFAA) spectrometry using EPA-821/R-96-005 Method 1638, EPA-821/R-96-006 Method 1639 , or equivalent.

Mercury is determined by oxidizing the samples with bromine monochloride, which breaks down organomercury bonds. Mercuric ions in the oxidized sample are reduced to elemental mercury with tin chloride, and then purged onto a gold trap as a means of preconcentration and interference removal. Mercury vapor is thermally desorbed into the fluorescence pathway. Mercury is analyzed using cold vapor atomic fluorescence (CVAF) spectroscopy according to EPA-600/R-94-111 Method 245.1 or equivalent.

The anions (nitrate, nitrite, chloride, fluoride, and sulfate) are determined using EPA-600/4-79-020 Method 300.0 or equivalent. The sample is introduced into an ion chromatograph, and the anions of interest are separated and measured.

\section{Milk}

Gamma-emitting radionuclides in milk are counted directly using either a $\mathrm{Ge}(\mathrm{Li})$ or HPGE detector with a multichannel, pulse-height analyzer. 
Tritium in water distilled from milk is counted directly with a liquid scintillation spectrometer.

Iodine- 129 is separated from milk with an anion-exchange resin, purified, and analyzed by mass spectrometry.

Iodine-131 is removed from milk with an anion-exchange resin. The iodine is eluted with sodium hypochlorite, purified, precipitated as palladium iodide, and beta counted with a low-background, gasflow proportional counter.

Strontium-90 is measured in the same manner as in air samples, but samples are purified with a cation resin, eluted with sodium chloride, and precipitated as a carbonate before exposure to fuming nitric acid.

\section{Foodstuffs}

Gamma-emitting radionuclides in foodstuffs are counted directly on either a Ge(Li) or HPGE detector with a multichannel, pulse-height analyzer.

Tritium in water distilled from farm produce is counted directly with a liquid scintillation spectrometer.

Iodine-129 in foodstuffs (other than milk) is determined after the sample is dried and weighed. The dried sample is counted directly with a low-energy photon detector (LEPD) system.

Plutonium-238 and plutonium-239/240 in foodstuffs are measured in the same manner as in air samples, after samples have been dried, ashed in a furnace, and treated with nitric acid.

Strontium-90 is measured in the same manner as in air samples, but samples are dried, ashed in a furnace, and treated with nitric acid before exposure to fuming nitric acid.

For technetium-99 determination, the sample is digested to inorganic salts with nitric acid and hydrogen peroxide, and the digestate is processed in the same manner as for water samples.

Uranium in foodstuffs is dry and/or wet ashed to an inorganic salt. The salts are dissolved in nitric acid and extracted into hexone for purification. The sample is then electrodeposited onto a stainless steel planchet and counted with an alpha spectrometer.

\section{Vegetation and Wildlife}

For technetium-99 determination, the sample is digested to inorganic salts with nitric acid and hydrogen peroxide and the digestate is processed in the same manner as for water samples.

Plutonium, strontium, uranium (isotopic), and gamma-emitting radionuclides are measured using the procedures described for foodstuffs. 


\section{Soil and Sediment}

All soil and sediment samples are pretreated by weighing, screening (less than or equal to 2 millimeters), drying, and ball milling to a constant particle size of 300 microns or less. Samples not requiring further pretreatment are counted directly to detect gamma- and low-energy photon-emitting radionuclides. For plutonium and strontium analyses requiring chemical separations, 1-gram aliquots of samples are dissolved with concentrated acids by heating in pressurized containers in a microwave oven.

Gamma-emitting radionuclides are counted on either a $\mathrm{Ge}(\mathrm{Li})$ or HPGE detector with a multichannel, pulse-height analyzer after the sample is placed in a Marinelli beaker.

Plutonium and strontium- 90 are measured after the sample is pretreated. Strontium is precipitated from the sample as strontium oxalate. The sample is then converted and precipitated as a carbonate; transferred to a planchet; and counted with a low-background, gas-flow proportional counter. After the strontium has been removed from the sample, the plutonium is coprecipitated with calcium oxalate, dissolved, and loaded onto an ion-exchange resin column. The plutonium is eluted from the resin column with nitric and hydrofluoric acids, deposited on a stainless steel or platinum disk, and counted with an alpha spectrometer.

Uranium analysis is conducted after the sample is pretreated using an ion-exchange column. The sample is electrodeposited onto a stainless steel planchet, then counted with an alpha spectrometer to determine isotopic uranium concentrations.

\section{Exceptions}

No exceptions have been taken to "should*" statements in DOE/EH-0173T.

\section{Quality Assurance and Quality Control}

In achieving the surveillance objectives identified in previous subsections, it is imperative that knowledge is maintained about the accuracy, precision, traceability, and limitations of data and information supporting project documentation. It is also imperative that an appropriate methodology to ensure control and legitimacy of project documentation is maintained. The quality of results is dependent on the control and verification of all components that provide input into the generation of reports and documentation. All components of work performed within the project are under an appropriate level of QA and QC scrutiny.

The goal of the $\mathrm{QA} / \mathrm{QC}$ program is to ensure that accurate, defensible data are produced. This subsection describes the elements of the program and how they are implemented. In obtaining the $\mathrm{QA} / \mathrm{QC}$ goal, a management commitment to operating a surveillance project that accurately reflects Hanford Site environmental impacts and radiation doses to the environment and public is required. Management 
commitment to QA/QC is ensured through PNNL-established management philosophies and is implemented through the Standards-Based Management System (PNNL 2000).

\section{Requirements}

The DOE QA requirements are contained in DOE Order 414.1A, which replaced DOE Order 5700.6C as defined in DOE/EH-0173T. DOE Order 414.1A requires that QA plans be developed and documented and recommends the judicious and selective application of appropriate and recognized standards. The DOE Order addresses 10 key elements but does not address environmental surveillance specifically. These requirements are implemented through the Standards-Based Management System (PNNL 2000), which gives direction for developing an activity-specific QA plan.

\section{Quality Assurance Plan}

Surface environmental surveillance is conducted under a project-specific QA plan. The QA plan addresses the 18 criteria of The American Society of Mechanical Engineers (ASME) NQA-1-1989 Edition, which meets the majority of the DOE Order 414.1A requirements, and is approved by PNNL.

\section{Assessments}

Independent assessments are performed on project activities and procedures to ensure compliance with project, PNNL, and DOE QA requirements. These assessments are initiated by the DOE-RL program manager, the PNNL project manager, the media task leader, or the quality engineer on a routine and/or random basis. Assessment results are documented and then reported and reviewed by responsible management and media task leaders. Corrective actions are taken, documented, and verified as applicable.

\section{Quality Control}

\section{Procedures}

The QC for quality-affecting activities is maintained through written procedures. Activities that affect quality and require written procedures are identified in the project-specific QA plan.

In addition, $\mathrm{QA} / \mathrm{QC}$ for service functions is defined in statements of work issued to the performing functional organization, whether internal to PNNL or those of an external contractor. The PNNL service functions are performed according to the QA plan and procedures established for that function, unless the statement of work identifies special requirements.

\section{Analytical Quality Control Program}

Contracted analytical laboratories are required to maintain and participate in analytical QA programs to determine analytical precision and accuracy and to operate under written and approved procedures, as defined by a contract statement of work. Reports are generated periodically (monthly or quarterly) to summarize intralaboratory QC data and performance. The QC reports, minimum detectable concentra- 
tions, and method detection limit determinations are reviewed by the task leader; deficiencies are identified and investigated. Corrective actions are documented, implemented, and verified. In addition to the laboratory's internal QC program, participation in national intercomparison studies is required.

Radiochemistry. The majority of the intralaboratory QC program consists of analyzing blanks, replicates, and National Institute of Standards and Technology traceable spike samples (which must comprise no less than $15 \%$ of all ordered tests) and maintaining data that validate determinations of current minimum detectable concentrations. Requirements for accuracy and precision for internal analytical QA are addressed below in Analytical Accuracy and Precision Criteria. Quarterly reports are generated to summarize intralaboratory QC data and performance. Use of Equation 37 from Chapter 6 in EPA 520/1-80-012 is designated for the determination of the minimum detectable concentration.

The contracted analytical laboratory participates in two national intercomparison studies. The laboratory is required to analyze applicable radionuclide-media samples from the DOE Quality Assessment Program operated by the Environmental Measurements Laboratory and the EPA Environmental Radioactivity Laboratory Intercomparison Studies Program. Additional QC data are generated by sending split or collocated (blind) duplicate samples to the laboratory and independent organizations (i.e., state, U.S. Food and Drug Administration, EPA) and challenging the laboratory with characterized (blind) reference samples as described in the project analytical QC plan. The characterized (blind) reference samples are developed to challenge the capabilities of the laboratory in areas of significance (important pathway radionuclide-media or historically weak analytical areas). Reference sample material is obtained from the National Institute of Standards and Technology, DOE, EPA, or other sources with a significant level of reliability and accountability. Criteria used for judging the performance on QC samples are derived from appropriate references (EPA-600/4-81-004, EML-608).

Reports of contractor performance in the DOE and EPA programs are required. Performances on blind samples (split or characterized reference) are evaluated by QC technical support personnel and reported to project management. These documents are reviewed and corrective actions (i.e., follow-up audits) taken if necessary.

The current radiochemistry analytical contract is with Severn Trent Laboratory, Richland, Washington, for all radiochemistry (except iodine-129) analyses. PNNL performs iodine-129 analyses under a statement of work.

Chemical (Nonradiochemical) Analysis. The QC program for the chemical laboratories providing services consists of analyzing blanks, replicates, matrix spikes, matrix spike duplicates, and laboratory control samples. The QC data are reported with the sample results.

Additional QC data may be generated by sending split or collocated (blind) duplicate samples to the laboratory and independent organizations (i.e., state, EPA) and challenging the laboratory with characterized (blind) reference samples as described in the project analytical QC plan. Reference sample material is obtained from the National Institute of Standards and Technology, DOE, EPA, or other sources with a significant level of reliability and accountability. 
The EPA intercomparison programs reports of performance are required for the commercial laboratory performing analytical services for the project. Performances on blind samples (split or characterized reference) are evaluated by QC technical support personnel and reported to project management. These documents are reviewed and corrective actions (i.e., follow-up audits) taken if necessary.

The current commercial chemical analysis contract is with Severn Trent Laboratory, Inc. Some metals analyses are performed by PNNL.

\section{Analytical Accuracy and Precision Criteria}

Radiochemical data-accuracy criteria call for analytical results of spiked samples to be within $20 \%$ to $30 \%$ of the known spike value. Accuracy is assessed using spiked samples and the criterion that $95 \%$ of the spiked sample results fall within the accuracy range given in Table III.A-3 for the various analysis types.

Precision requirements are met when replicate results (above detectable concentrations) fall within $\pm 30 \%$ relative percent difference for water samples and within three standard deviations for all other media samples.

Accuracy and precision of analytical results are assessed by analyzing spikes, blanks, and replicate samples. Such samples comprise no less than $15 \%$ of all ordered radiochemical tests.

For nonradiochemical tests ordered, QC criteria are defined above in Chemical Analysis. Spikes and blanks are included in each batch of samples. Spikes have, insofar as possible, the matrix, volume, and other relevant characteristics of the actual samples being analyzed. Blanks are matrix or reagent blanks. Reagent and sample media blanks will be analyzed with each batch of samples.

\section{Field Radiation Survey Instruments}

Field survey instruments are calibrated with appropriate radiation sources and standards traceable to the National Institute of Standards and Technology. Calibration methods and frequencies for field survey equipment are determined and controlled by the PNNL Radiation Standards and Calibration Project, which provides radiation calibration service (including pick up and delivery) to the Hanford Site. Special studies are performed periodically by technical support personnel to characterize detection capabilities of more complex instruments. Instruments are performance tested with appropriate check sources before and during (if required procedurally) surveys. Instruments determined not to be performing adequately are returned to the PNNL Radiation Standards and Calibration Project for maintenance and calibration.

\section{Exceptions}

No exceptions have been taken to "should" statements in DOE/EH-0173T. 
Table III.A-3. Accuracy Requirements

\begin{tabular}{llc}
\multicolumn{1}{c}{ Type of Analysis } & & Precision \\
${$\cline { 1 - 1 }$} }$ & & $\pm 20 \%$ \\
Liquid scintillation & & $\pm 20 \%$ \\
Liquid scintillation with chemical separation & & $\pm 30 \%$ \\
Alpha spectrometry & & $\pm 25 \%$ \\
Beta proportional & & $\pm 30 \%$ \\
Alpha proportional & & $\pm 30 \%$ \\
Uranium total, fluorimetry or phosphorimetry & & $\pm 30 \%$ \\
Uranium isotopic, gamma (low-energy photon & & $\pm 30 \%$ \\
spectroscopy &
\end{tabular}

\section{Records Management and Reporting}

This subsection identifies and outlines the plans for record keeping and reporting to meet applicable requirements.

General record-keeping and reporting requirements are outlined in DOE Orders 5400.1 and 5400.5 and DOE/EH-0173T. These DOE Orders and guidance specify the reporting responsibilities, timing, and distribution of routine reports and contain some details on the required content and format. Requirements for preparing and distributing accident and occurrence reports are outlined in DOE Orders 225.1A and 232.1A.

\section{Record Keeping}

DOE Order 5400.1 (pp. IV-3 and IV-8) and DOE Order 5400.5 (p. II-15) require the maintenance and retention of auditable records relating to environmental surveillance, the fate of radioactive materials in the environment and their impact on radiation doses to the public, records of calculations, computer programs, raw data, or procedures. Records are to be protected against damage or loss; generally, this means separate storage of duplicates. DOE Guide $1324.5 \mathrm{~B}$ establishes requirements for the retention and disposal of environmental contamination measurement records, which apply to surveillance records. DOE Order 414.1A establishes QA requirements.

These record-keeping requirements are implemented by the PNNL QA plan, which conforms to the requirements of DOE Order 414.1A and 10 CFR 830.120 as interpreted and implemented by PNNL (1997). 


\section{Reporting}

The reporting requirements applicable to environmental surveillance are contained in the following:

- DOE Orders 5400.1 and 231.1

- annual Hanford Site environmental report to be submitted to DOE-HQ and the public by October 1 of the following year

Surveillance results are formally reported through the annual Hanford Site environmental report (e.g., PNNL-13230 for 1999). The distribution of the report is reviewed each year to ensure that potentially affected federal, state, and local governments and agencies; Indian Nations; environmental interests; business interests; and owners of Hanford Reach islands are notified concerning the environmental status of the site and surroundings.

- preoperational environmental survey report

- environmental monitoring plan to be reviewed annually and updated at least every 3 years

The monitoring plan is maintained per DOE Order 5400.1 and DOE/EH-0173T; the preoperational report will be prepared as directed by DOE. Topical reports describing the fate of radioactive materials in the environment are issued periodically, for information not reportable through the reports listed above, to meet site-specific and public assurance needs.

- DOE Orders 225.1A and 232.1A

- occurrence reporting: submit emergency, unusual occurrence, or off-normal occurrence reports (e.g., environmental releases of significant offsite consequences, threatening or degrading to the environment, exceedances of compliance or administrative limits, or degradation of compliance monitoring systems)

- notifications: submit notifications (e.g., damages, releases to the environment, occurrences resulting in press releases, or discovery of significant contamination)

Occurrences are reported as required by the cited DOE Orders.

- DOE Order 5400.5

- noncompliance: requires reporting when requirements will not be or have not been met (p. I-4)

- potential doses exceeding reporting limits: requires reporting actual or potential exposures of the public that could result in either 1) a dose from DOE sources exceeding 10 millirems EDE in a 
year, or exceeding any limit or failing to meet any other requirement specified, or any other legal or applicable limits; or 2) a combined dose equal to or greater than 100 millirems EDE in a year from DOE and other anthropogenic sources.

Noncompliances with the DOE Order are reported as required.

Unusual results or trends in surveillance data that occur between issuances of the annual Hanford Site environmental report (e.g., PNNL-13230 for 1999) are reported, when they occur, to DOE and to the appropriate facility managers. Unusual concentration reporting levels have been established, based on the environmental concentrations that would lead to an offsite public dose of either 1 or 10 millirems per year, depending on the media, assuming that the condition persisted for an entire year. Unusual concentration reporting levels to be utilized are shown in Table III.A-4.

\section{Exceptions}

No exceptions have been taken to "should"" statements in DOE/EH-0173T. 
Table III.A-4. Hanford Site Surface Environmental Surveillance Unusual Concentration Reporting Levels ${ }^{(\mathfrak{a})}$

\begin{tabular}{|c|c|c|c|c|c|c|c|c|c|c|c|c|c|c|}
\hline & ${ }^{3} \mathrm{H}$ & ${ }^{60} \mathrm{Co}$ & ${ }^{85} \mathrm{Kr}$ & ${ }^{90} \mathrm{Sr}$ & ${ }^{99} \mathrm{Tc}$ & ${ }^{106} \mathrm{Ru}$ & ${ }^{129} I$ & ${ }^{131} \mathrm{I}$ & ${ }^{137} \mathrm{Cs}$ & ${ }^{154} \mathrm{Eu}$ & Natural U & ${ }^{234,5,8} \mathrm{U}$ & ${ }^{238,9400} \mathrm{Pu}$ & ${ }^{24 !} \mathrm{Am}$ \\
\hline $\mathrm{Air}, \mathrm{pCi} / \mathrm{m}^{3}$ & $1.2 \mathrm{E}+02$ & $2.7 \mathrm{E}-01$ & $3.0 \mathrm{E}+04$ & 7.2E-02 & (b) & $1.8 \mathrm{E}-01$ & $2.8 \mathrm{E}-03$ & $4.7 \mathrm{E}-02$ & $1.1 \mathrm{E}-01$ & $\cdots$ & $\ldots$ & $8.0 \mathrm{E}-04$ & $3.9 \mathrm{E}-04$ & $\cdots$ \\
\hline River water, $\mathrm{pCi} / \mathrm{L}$ & $1.0 \mathrm{E}+04$ & $1.7 \mathrm{E}+00$ & $\cdots$ & $3.0 \mathrm{E}-01$ & $8.4 \mathrm{E}+00$ & $1.5 \mathrm{E}+00$ & $7.3 \mathrm{E}-01$ & $2.7 \mathrm{E}-00$ & $3.5 \mathrm{E}-02$ & $\cdots$ & $3.3 \mathrm{E}+00$ & $3.3 \mathrm{E}+00$ & $1.1 \mathrm{E}+00$ & $\cdots$ \\
\hline Drinking water, $\mathrm{pCi} / \mathrm{L}$ & $2.0 \mathrm{E}+04$ & $5.0 \mathrm{E}+01$ & $\ldots$ & $1.0 \mathrm{E}+01$ & $6.2 \mathrm{E}+02$ & (c) & $5.0 \mathrm{E}+00$ & $3.0 \mathrm{E}+01$ & $3.0 \mathrm{E}+01$ & $\ldots$ & (c) & $5.0 \mathrm{E}+00$ & (c) & $\ldots$ \\
\hline Dairy products, $\mathrm{pCi} / \mathrm{L}$ & $5.4 \mathrm{E}+04$ & (c) & -- & $2.7 \mathrm{E}+01$ & $-\cdot-$ & (c) & $1.3 \mathrm{E}+01$ & $8.1 \mathrm{E}+01$ & $8.1 E+01$ & $\cdots$ & $\cdots$ & (c) & (c) & -- \\
\hline $\begin{array}{l}\text { Meats, poultry, eggs, } \\
\mathrm{pCi} / g \text { wet weight }\end{array}$ & $1.8 \mathrm{E}+02$ & (c) & $\cdots$ & $9.1 \mathrm{E}-02$ & $\cdots$ & (c) & (c). & (c) & $2.7 \mathrm{E}-01$ & $\ldots$ & $\ldots$ & (c) & (c) & -- \\
\hline Cereals and grains, $\mathrm{pCi} / \mathrm{g}$ & $1.8 \mathrm{E}+02$ & (c) & $\cdots$ & $9.1 \mathrm{E}-02$ & $\cdots$ & (c) & (c) & (c) & $2.7 \mathrm{E}-01$ & $\ldots$ & ... & (c) & $2.5 \mathrm{E}-01$ & $\cdots$ \\
\hline Leafy vegetables, pCi/g & $5.0 \mathrm{E}+02$ & (c) & -- & $2.7 \mathrm{E}-01$ & $1.5 \mathrm{E}+0 \mathrm{I}$ & (c) & $1.3 \mathrm{E}-01$ & (c) & $6.0 \mathrm{E}-01$ & $\cdots$ & $\cdots$ & (c) & (c) & -.- \\
\hline $\begin{array}{l}\text { Fruit and other vegetables, } \\
\mathrm{pCi} / \mathrm{g}\end{array}$ & $5.0 \mathrm{E}+01$ & (e) & $\cdots$ & $2.5 \mathrm{E}-02$ & $1.3 \mathrm{E}+00$ & (c) & $1.2 \mathrm{E}-02$ & (c) & $6.0 \mathrm{E}-02$ & $\cdots$ & $\cdots$ & $1.1 \mathrm{E}-01$ & $6.2 \mathrm{E}-02$ & ..- \\
\hline Wine, ${ }^{(d)} \mathrm{pCi} / \mathrm{L}$ & $2.0 \mathrm{E}+05$ & -- &.-- & (c) & $\cdots$ & $-\cdots$ & (c) & (c) & $3.0 \mathrm{E}+02$ & --. & $\ldots$ & (c) & (c) & -.. \\
\hline Wildlife meats, ${ }^{(e)} \mathrm{pCi} / \mathrm{g}$ & $\cdots$ & $9.1 \mathrm{E}-01$ & $\cdots$ & $1.8 \mathrm{E}-01$ & $1.1 E+01$ & $\cdots$ & $\cdots$ & --- & $5.4 \mathrm{E}-01$ & -- & $\cdots$ & $9.5 \mathrm{E}-01$ & $5.0 \mathrm{E}-01$ & $\cdots$ \\
\hline Soil, ${ }^{(0)} \mathrm{pCi} / \mathrm{g}$ & (c) & (c) & --. & $3.0 \mathrm{E}-01$ & $-\cdots$ & (c) & (c) & (c) & $5.8 \mathrm{E}+00$ & $\ldots$ & $8.0 \mathrm{E}+00$ & $3.1 \mathrm{E}+00$ & $3.7 \mathrm{E}+00$ & $5.5 \mathrm{E}-01$ \\
\hline $\begin{array}{l}\text { Vegetation and alfalfa, } \\
\mathrm{pCi} / \mathrm{g}\end{array}$ & (c) & (c) & $\cdots$ & $1.5 \mathrm{E}+00$ & $1.6 \mathrm{E}+02$ & (c) & (c) & (c) & $2.7 \mathrm{E}-01$ & $\cdots$ & $1.3 \mathrm{E}+01$ & $6.6 \mathrm{E}+00$ & $4.2 \mathrm{E}+03$ & $\cdots$ \\
\hline Sediment, pCi/g & (c) & $1.4 \mathrm{E}+00$ & $\cdots$ & $3.0 \mathrm{E}+04$ & (c) & $1.4 \mathrm{E}+01$ & (c) & (c) & $6.0 \mathrm{E}+00$ & $2.6 \mathrm{E}+00$ & (c) & $5.0 \mathrm{E}+01$ & $8.1 \mathrm{E}+04$ & $\cdots$ \\
\hline $\begin{array}{l}\text { (a) = Not applicable. } \\
\text { (a) Concentrations are sho } \\
\text { (b) Not routinely analyzed } \\
\text { (c) Analysis is not typically } \\
\text { (d) Based on estimated ma } \\
\text { (e) Based on estimated ma } \\
\text { river-water pathway ca } \\
\text { (f) Reporting levels for }{ }^{90} \mathrm{~S}\end{array}$ & $\begin{array}{l}\text { to two sig } \\
\text { d/or not co } \\
\text { eported, bu } \\
\text { mally expos } \\
\text { mally expos } \\
\text { ulation. } \\
\text { and }{ }^{137} \mathrm{Cs} \text { in }\end{array}$ & $\begin{array}{l}\text { icant figures } \\
\text { dered a sign } \\
\text { eterminatio } \\
\text { individual } \\
\text { individual } \\
\text { il based on }\end{array}$ & $\begin{array}{l}\text { r consisten } \\
\text { ofant dose c } \\
\text { of other rep } \\
\text { nsumption } \\
\text { nsumption } \\
0 \text { mrem ef }\end{array}$ & $\begin{array}{l}\text {, but this do } \\
\text { tributor. } \\
\text { table levels } \\
\text { e of } 70 \mathrm{~L}(\sim \\
\text { e of } 40 \mathrm{~kg} \mathrm{o} \\
\text { tive dose eq }\end{array}$ & $\begin{array}{l}\text { not imply t } \\
\text { luded this } \\
\text { o bottles) o } \\
\text { ildlife mea } \\
\text { alent. }\end{array}$ & $\begin{array}{l}\text { analytical } \\
\text { dium-radio } \\
\text { vine per yea } \\
\text { er year (fro }\end{array}$ & $\begin{array}{l}\text { cision, whi } \\
\text { clide pathw } \\
\text { fish, deer, } \mathrm{f}\end{array}$ & $\begin{array}{l}\text { varies with } \\
\text { dose contri } \\
\text { l, etc.); triti }\end{array}$ & $\begin{array}{l}\text { easurement } \\
\text { ution. } \\
\text { n concentra }\end{array}$ & are arco & ision of the & $\begin{array}{l}\text { se model } \\
\text { only (not o }\end{array}$ & wildhife ty & from the \\
\hline
\end{tabular}




\section{References}

10 CFR 830.120, Code of Federal Regulations, Title 10, Part 830, Chapter 120. Nuclear Safety Management, Quality Assurance Requirements.

40 CFR 61, Code of Federal Regulations, Title 40, Part 61. National Emission Standards for Hazardous Air Pollutants.

65 FR 114. June 13, 2000. Presidential Proclamation 7319, "Establishment of the Hanford Reach National Monument." Federal Register.

ANSI (American National Ștandards Institute) N42.17. 1989. Performance Specifications for Health Physics Instrumentation: (A) Portable Instrumentation for Use in Normal Environmental Conditions;

(B) Occupational Airborne Radioactivity Monitoring Instrumentation; and (C) Portable Instrumentation for Use in Extreme Environmental Conditions. Institute of Electrical and Electronics Engineers, Inc., New York.

ASME (The American Society of Mechanical Engineers) NQA-1-1989 Edition. 1989. Quality Assurance Program Requirements for Nuclear Facilities, An American National Standard. New York.

ARH-CD-775. 1976. Geohydrologic Study of the West Lake Basin. R. E. Gephart, P. A. Eddy, R. C. Arnett, and G. A. Robinson, Atlantic Richfield Hanford Company, Richland, Washington.

BHI-EE-09. Environmental Data Management Procedures Manual. In Library, ERC Controlled Manual List [Online]. Available URL: http://www.erc.rl.gov/

BNWL-90. 1965. Evaluation of Radiological Conditions in the Vicinity of Hanford for 1964. R. F. Foster and R. H. Wilson, Pacific Northwest Laboratory, Richland, Washington.

BNWL-316. 1966. Evaluation of Radiological Conditions in the Vicinity of Hanford for 1965. R. F. Foster, Pacific Northwest Laboratory, Richland, Washington.

BNWL-439. 1967. Evaluation of Radiological Conditions in the Vicinity of Hanford for 1966. J. F. Honstead, Pacific Northwest Laboratory, Richland, Washington.

BNWL-983. 1969. Evaluation of Radiological Conditions in the Vicinity of Hanford for 1967. J. P. Corley and C. B. Woolridge, Pacific Northwest Laboratory, Richland, Washington.

BNWL-1341. 1970. Evaluation of Radiological Conditions in the Vicinity of Hanford for 1968. W. L. Fisher and C. B. Wilson, Pacific Northwest Laboratory, Richland, Washington.

BNWL-1505. 1970. Evaluation of Radiological Conditions in the Vicinity of Hanford for 1969. J. P. Corley, Pacific Northwest Laboratory, Richland, Washington. 
BNWL-1669. 1973. Environmental Surveillance at Hanford for CY-1970. J. P. Corley, Pacific Northwest Laboratory, Richland, Washington.

BNWL-SA-4534. 1973. An Analytical Technique for Distributing Air Sampling Locations Around Nuclear Facilities. D. A. Waite, Battelle, Pacific Northwest Laboratories, Richland, Washington; presented at Health Physics Society Annual Meeting, June 17, 1973, Miami, Florida.

BNWL-SA-4676. 1973. Analysis of an Analytical Technique for Distributing Air Sampling Locations Around Nuclear Facilities. D. A. Waite, Battelle, Pacific Northwest Laboratories, Richland, Washington; presented at the Third International Congress on International Radiation Protection Association, September 9 through 14, 1973 in Washington, D.C.; published as CONF-73090-P1, pp. 406-410.

Comprehensive Environmental Response, Compensation, and Liability Act of 1980, as amended, Public Law 96-510, 94 Stat. 2767, 42 USC 9601 et seq.

DOE/EH-0173T. 1991. Environmental Regulatory Guide for Radiological Effluent Monitoring and Environmental Surveillance. Assistant Secretary for Environment, Safety and Health, U.S. Department of Energy, Washington, D.C.

DOE/EM-0327. 1997. Accelerating Cleanup: Focus on 2006, Discussion Draft. Office of Environmental Management, U.S. Department of Energy, Washington, D.C.

DOE Guide 1324.5B. "Implementation Guide for Records Management."

DOE Order 225.1. "Accident Investigations."

DOE Order 231.1. "Environment, Safety, and Health Reporting."

DOE Order 232.1. "Occurrence Reporting and Processing of Operations Information."

DOE Order 414.1A. "Quality Assurance."

DOE Order 5400.1. "General Environmental Protection Program."

DOE Order 5400.5. "Radiation Protection of the Public and the Environment."

DOE Order 5700.6C. "Quality Assurance."

DOE/RL-96-92. 1996. Hanford Strategic Plan. U.S. Department of Energy, Richland, Washington.

DOE/RL-99-41. 1999. Radionuclide Air Emissions Report for the Hanford Site, Calendar Year 1998. L. P. Diediker, Waste Management Federal Services of Hanford, Inc., and K. Rhoads, Pacific Northwest National Laboratory, Richland, Washington. 
Ecology - Washington State Department of Ecology, U.S. Environmental Protection Agency, and U.S. Department of Energy. 1998. Hanford Federal Facility Agreement and Consent Order. Document No. 89-10, Rev. 5 (The Tri-Party Agreement), Olympia, Washington.

EGG-10617-1062. 1990. An Aerial Radiological Survey of the Hanford Site and Surrounding Area, Richland Washington - Date of Survey: July-August 1988. Remote Sensing Laboratory operated for DOE by EG\&G/EM, Idaho Falls, Idaho.

EML-608. 2000. Semi-Annual Report of the Department of Energy, Office of Environmental Management, Quality Assessment Program. P. Greenlaw and A. Berne, Environmental Measurements Laboratory, U.S. Department of Energy, New York.

EPA-402-B-92-001. 1992. User's Guide for CAP88-PC, Version 1.0. B. S. Parks, Office of Radiation Programs, U.S. Environmental Protection Agency, Las Vegas, Nevada.

EPA-520/1-80-012. 1980. Upgrading Environmental Radiation Data: Health Physics Society Committee Report HPSR-1. Office of Radiation Programs, U.S. Environmental Protection Agency, Washington, D.C.

EPA-600/4-79-020. 1983. Methods for Chemical Analysis of Water and Wastes. U.S. Environmental Protection Agency, Cincinnati, Ohio.

EPA-600/4-81-004. 1981. Environmental Radioactivity Laboratory Intercomparison Studies Program: Fiscal Year 1980-81. A. B. Jarvis and L. Siu, U.S. Environmental Protection Agency, Las Vegas, Nevada.

EPA-600/R-94-111. 1994. Methods for the Determination of Metals in Environmental Samples, Supplement I. U.S. Environmental Protection Agency, Washington, D.C.

EPA-821/R-96-005. 1996. Determination of Trace Elements in Ambient Waters by Inductively Coupled Plasma-Mass Spectrometry (Draft). U.S. Environmental Protection Agency, Washington, D.C.

EPA-821/R-96-006. 1996. Determination of Trace Elements in Ambient Waters by Stabilized Temperature Graphite Furnace Atomic Absorption (Draft). U.S. Environmental Protection Agency, Washington, D.C.

HNF-EP-0527-9, Rev. 0. 2000. Environmental Releases for Calendar Year 1999. D. J. Rokkan, Fluor Hanford, Inc., Richland, Washington.

HNF-EP-0573-5. 1997. Hanford Site Near-Facility Environmental Monitoring Annual Report, Calendar Year 1996. C. J. Perkins, A. R. Johnson, B. M. Markes, S. M. McKinney, R. M. Mitchell, and R. K. Price, Fluor Daniel Hanford, Inc., Richland, Washington.

HW-69369. 1962. A Compilation of Basic Data Relating to the Columbia River Section 8 - Dispersion of Reactor Effluent in the Columbia River. J. K. Soldat, General Electric, Richland, Washington. 
HW-80991. 1964. Evaluation of Radiological Conditions in the Vicinity of Hanford for 1963.

R. F. Foster and R. H. Wilson, U.S. Atomic Energy Commission, Washington, D.C.

International Commission on Radiological Protection. 1977. ICRP Publication 26, Recommendations of the International Commission on Radiological Protection. Annals of the ICRP, Vol. 1, No. 3, Pergamon Press, Elmsford, New York.

International Commission on Radiological Protection. 1979a. ICRP Publication 30, Part 1, Limits for Intakes of Radionuclides by Workers. Annals of the ICRP, Vol. 2, No. 3-4, Pergamon Press, Elmsford, New York.

International Commission on Radiological Protection. 1979b. ICRP Publication 30, Supplement to Part 1, Limits for Intakes of Radionuclides by Workers. Annals of the ICRP, Vol. 3, No. 1-4, Pergamon Press, Elmsford, New York.

International Commission on Radiological Protection. 1980. ICRP Publication 30, Part 2, Limits for Intakes of Radionuclides by Workers. Annals of the ICRP, Vol. 4, No. 3-4, Pergamon Press, Elmsford, New York.

International Commission on Radiological Protection. 1981a. ICRP Publication 30, Supplement to Part 2, Limits for Intakes of Radionuclides by Workers. Annals of the ICRP, Vol. 5, No. 1-6, Pergamon Press, Elmsford, New York.

International Commission on Radiological Protection. 1981b. ICRP Publication 30, Part 3 Including Addendum to Parts 1 and 2, Limits for Intakes of Radionuclides by Workers. Annals of the ICRP, Vol. 6, No. 2-3, Pergamon Press, Elmsford, New York.

International Commission on Radiological Protection. 1982a. ICRP Publication 30, Supplement A to Part 3, Limits for Intakes of Radionuclides by Workers. Annals of the ICRP, Vol. 7, No. 1-3, Pergamon Press, Elsmford, New York.

International Commission on Radiological Protection. 1982b. ICRP Publication 30, Supplement B to Part 3 Including Addendum to Supplements to Parts 1 and 2, Limits for Intakes of Radionuclides by Workers. Annals of the ICRP, Vol. 8, No. 1-3, Pergamon Press, Elmsford, New York.

International Commission on Radiological Protection. 1988. ICRP Publication 30, Part 4, Limits for Intakes of Radionuclides by Workers: An Addendum. Annals of the ICRP, Vol. 19, No. 4, Pergamon Press, Elmsford, New York.

PNL-3127. 1980. Radiological Survey of Exposed Shorelines and Islands of the Columbia River Between Vernita and the Snake River Confluence. M. J. Sula, Pacific Northwest Laboratory, Richland, Washington.

PNL-3777 Rev. 2. 1993. Recommended Environmental Dose Calculation Methods and HanfordSpecific Parameters. R. G. Schreckhise, K. Rhoads, J. S. Davis, B. A. Napier, and J. V. Ramsdell, Pacific Northwest Laboratory, Richland, Washington. 
PNL-6464. 1988. Environmental Monitoring at Hanford for 1987. R. E. Jaquish and P. J. Mitchell, Pacific Northwest Laboratory, Richland, Washington.

PNL-6584. 1988. GENII - The Hanford Environmental Radiation Dosimetry Software System. B. A. Napier, R. A. Peloquin, D. L. Strenge, and J. V. Ramsdell, 3 volumes, Pacific Northwest Laboratory, Richland, Washington.

PNL-7124. 1989. The Determination of the Penetrating Radiation Dose at Hanford. L. A. Rathbun, Pacific Northwest Laboratory, Richland, Washington.

PNL-7803. 1991. Hanford Area 1990 Population and 50-Year Projections. D. M. Beck, B. A. Napier, M. J. Scott, A. G. Thurman, M. D. Davis, D. B. Pittenger, S. F. Shindle, and N. C. Batishko, Pacific Northwest Laboratory, Richland, Washington.

PNL-8150. 1992. Methods for Estimating Doses to Organisms from Radioactive Materials Released into the Aquatic Environment. D: A. Baker and J. K. Soldat, Pacific Northwest Laboratory, Richland, Washington.

PNL-8531. 1993. Columbia River Monitoring: Distribution of Tritium in Columbia River Water at the Richland Pumphouse. R. L. Dirkes, Pacific Northwest Laboratory, Richland, Washington.

PNL-8789. 1993. Investigation of Exposure Rates and Radionuclide and Trace Metal Distributions Along the Hanford Reach of the Columbia River. A. T. Cooper and R. K. Woodruff, Pacific Northwest Laboratory, Richland, Washington.

PNL-MA-580, Rev. 3. 2000. Surface Environmental Surveillance Procedures Manual. R. W. Hanf and T. M. Poston (eds.), Pacific Northwest National Laboratory, Richland, Washington.

PNNL. 2000. In Standards-Based Management System (accessed online on November 1, 2000). Available URL: http://sbms/ch00d010.htm

PNNL-6415, Rev. 12. 2000. Hanford Site National Environmental Policy Act (NEPA) Characterization. D. A. Neitzel (ed.), Pacific Northwest National Laboratory, Richland, Washington.

PNNL-10714. 1995. Nonradiological Chemical Pathway Analysis and Identification of Chemicals of Concern for Environmental Monitoring at the Hanford Site. M. L. Blanton, A. T. Cooper, and K. J. Castleton; Pacific Northwest National Laboratory, Richland, Washington.

PNNL-11472. 1997. Hanford Site Environmental Report for Calendar Year 1996. R. L. Dirkes and R. W. Hanf (eds.), Pacific Northwest National Laboratory, Richland, Washington.

PNNL-13109. 2000. Hanford Site Environmental Surveillance Master Sampling Schedule. L. E. Bisping, Pacific Northwest National Laboratory, Richland, Washington.

PNNL-13230. 2000. Hanford Site Environmental Report for Calendar Year 1999. T. M. Poston and R. W. Hanf (eds.), Pacific Northwest National Laboratory, Richland, Washington. 
PNNL-13230, APP. 1. 2000. Hanford Site Environmental Surveillance Data Report for Calendar Year 1999. L. E. Bisping, Pacific Northwest National Laboratory, Richland, Washington.

SW-846. 1986. Test Methods for Evaluating Solid Wastes: Physical/Chemical Methods, 3rd ed. Office of Solid Waste and Emergency Response, U.S. Environmental Protection Agency, Washington, D.C.

Turner, B. D. 1970. Workbook of Atmospheric Dispersion Estimates. U.S. Environmental Protection Agency, Research Triangle Park, North Carolina.

WAC 173-201A, Washington Administrative Code. Water Quality Standards for Surface Waters of the State of Washington. Olympia, Washington. 


\section{Hanford Site Environmental Monitoring Plan}

\section{Section III.B. Groundwater Monitoring}

Prepared by: Date:

M. J. Hartman, Pacific Northwest National Laboratory

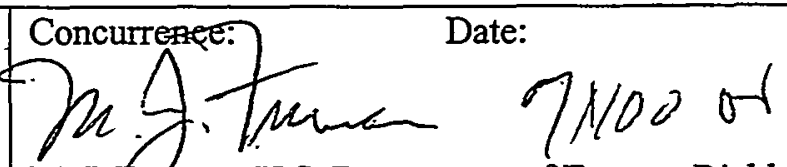

M. J. Eurman, U.S. Department of Energy, Richland Operations Office 


\section{Introduction}

Groundwater monitoring is a critical element of the U.S. Department of Energy's (DOE's) environmental monitoring program at the Hanford Site because an unconfined aquifer and a system of deeper confined aquifers underlie the site. Groundwater from the unconfined aquifer entering the Columbia River is a significant pathway for transport of contaminants.

Groundwater monitoring is conducted at the Hanford Site for a variety of purposes: near-field monitoring of specific facilities, sitewide monitoring of existing contaminant plumes, monitoring to assess the effectiveness of groundwater remediation activities, and offsite monitoring to ensure that Hanford Site contaminants are not present. Because the Hanford Site has multiple, extensive, and unique groundwater pollution problems, DOE has established an integrated groundwater monitoring project to ensure protection of the public and the environment while improving the efficiency of monitoring operations.

\section{Regulatory Drivers}

The regulatory framework governing groundwater monitoring at the Hanford Site consists of federal and state regulations, agreements, and DOE orders. DOE Order 5400.1 establishes a groundwater monitoring program that meets the requirements of DOE Order 5400.5, which deals with radiation protection of the public and the environment, and other applicable federal and state regulations. According to DOE Order 5400.1, groundwater monitoring programs shall be conducted onsite and in the vicinity of DOE facilities for the following purposes:

- obtaining data for determining baseline conditions of groundwater quality and quantity

- demonstrating compliance with and implementation of all applicable regulations and DOE Orders

- providing data to permit the early detection of groundwater pollution or contamination

- identifying existing and potential sources of groundwater contamination and maintaining surveillance of these sources

- providing a reporting mechanism for detected groundwater pollution or contamination

- providing data on which decisions can be made concerning land disposal practices and the management and protection of groundwater resources.

DOE Order 5400.1 also stipulates that, where applicable, groundwater monitoring around facilities be designed and implemented in accordance with regulations in Title 40, Code of Federal Regulations, Part 264 (40 CFR 264) or 265, Subpart F (pursuant to the Resource Conservation and Recovery Act of 1976 [RCRA]). DOE Order 5820.2A, which deals with radioactive waste management, also requires groundwater monitoring; specifically, a system of groundwater or vadose zone monitoring wells meeting 
RCRA requirements ( 40 CFR 264) shall be installed, as a minimum, around clusters of liquid wastestorage tanks. DOE Order 5820.2A also stipulates that groundwater be monitored around low-level waste facilities.

RCRA establishes regulatory standards for the generation, transportation, storage, treatment, and disposal of hazardous waste that applies to active waste management facilities and facilities undergoing closure. As authorized by the U.S. Environmental Protection Agency (EPA), state of Washington regulations (WAC 173-303) implement RCRA groundwater requirements in lieu of the federal regulations. WAC 173-304, which deals with solid waste, and WAC 173-216, which deals with permitted liquid discharges, also contain groundwater protection and monitoring requirements that apply to activities at the Hanford Site. RCRA corrective action requirements apply to inactive sites that have received RCRA permits. The Comprehensive Environmental Response, Compensation, and Liability Act of 1980 (CERCLA) and the Superfund Amendments and Reauthorization Act of 1986 (SARA), which are implemented through EPA regulations in 40 CFR 300, establish groundwater monitoring requirements for other inactive past-practice waste sites. Under these laws, three areas of the Hanford Site $(100,200$, and 300 Areas) are currently listed on the National Priorities List (40 CFR 300 Appendix B).

To coordinate the actions of various regulatory authorities and provide a strategy to achieve regulatory compliance and waste-site cleanup, the Hanford Federal Facility Agreement and Consent Order (also known as the Tri-Party Agreement) (Ecology et al. 1998) was established. This agreement between DOE; EPA, and the Washington State Department of Ecology (Ecology) provides for the interface of overlapping regulatory programs. The agreement specifies that both active and inactive treatment, storage, or disposal (TSD) units that have received RCRA permits will be managed and closed under $\mathrm{RCRA}$ regulations, including groundwater monitoring requirements. Other past-practice waste sites will be addressed under CERCLA regulations. Contaminated groundwater will be addressed as a CERCLA source of contamination. However, all CERCLA actions will meet RCRA corrective action standards under the agreement. In addition, CERCLA remedial actions at groundwater operable units designated as RCRA past-practice units will be incorporated into the Hanford Facility RCRA Permit (Ecology 1994). Under criteria established in the Tri-Party Agreement, a "lead regulatory agency" is designated for each operable unit to avoid inconsistency and duplication of effort.

\section{Project Management and Objectives}

In the past, groundwater programs were independently developed to address the needs of various programs, including CERCLA, RCRA, WAC 173-216, and DOE Orders. Because of increasing groundwater program overlap, DOE recognized the need for a more effective, consistent, and objective project. Therefore, in 1996, DOE directed its contractors to integrate the various groundwater programs into one consolidated project. The Hanford Groundwater Monitoring Project is designed to address all groundwater monitoring needs at the site, eliminate regulatory program redundancy, and establish a costeffective hierarchy for groundwater monitoring activities. Specific objectives of the Hanford Groundwater Monitoring Project are the following:

- maintaining and verifying compliance with all applicable groundwater regulations

- characterizing and defining hydrogeologic, physical, and chemical trends in the groundwater system

- establishing baselines of groundwater quality 
- providing continuing, independent assessment of groundwater remediation activities

- identifying and quantifying new or existing groundwater problems.

The Hanford Site groundwater protection management plan (DOE/RL-89-12) summarizes groundwater protection policies, project integration activities, program scope, and responsibilities. The groundwater protection management plan includes near-field monitoring at RCRA and other facilities, sitewide and offsite monitoring of groundwater contaminant migration conducted under the environmental surveillance program, and monitoring conducted to support groundwater remediation projects under CERCLA or RCRA corrective actions.

Pacific Northwest National Laboratory (PNNL) manages the Hanford Groundwater Monitoring Project in accordance with an established quality assurance plan, which conforms to the requirements of 10 CFR 830.120 as interpreted and implemented by the Standards-Based Management System (PNNL 2000).

Monitoring-well networks are located and constructed based on data quality objectives and/or criteria established in site-specific or regional monitoring plans. Groundwater monitoring at RCRA TSD units is conducted in accordance with site-specific groundwater monitoring plans prepared and maintained by PNNL that conform to RCRA regulatory requirements. A project scientist is assigned to each site or logical grouping of sites and is responsible for ensuring execution of the plan. RCRA corrective action and CERCLA past-practice groundwater monitoring requirements are documented in interim and final records of decision and implementing plans. As required by DOE Orders, additional wells across the Hanford Site are sampled to monitor movement of existing contaminant plumes and to determine the impact of facilities not specifically addressed by other regulations. These wells comprise the sitewide environmental surveillance network.

\section{General Groundwater Monitoring Information}

This section provides general information for all Hanford Site groundwater monitoring activities performed by the Hanford Groundwater Monitoring Project regardless of the specific purpose or regulatory driver. This is followed by sections with information that is applicable to near-field groundwater monitoring, monitoring to support CERCLA and RCRA corrective actions, and sitewide environmental surveillance monitoring of groundwater.

\section{Construction and Maintenance of Wells}

The Hanford Groundwater Monitoring Project uses wells built from the 1940 s to the present. Most older monitoring wells on the Hanford Site are 10, 15, or 20 centimeters in diameter and are constructed of carbon-steel casing. Most newer wells are constructed of 10-centimeter, stainless steel casing. Most unconfined aquifer wells are completed with well screens or perforations in the upper 3 to 6 meters of the aquifer.

For older wells, a fitness-for-use evaluation is conducted, and appropriate limitations are designated. Wells with limitations are sampled for a limited set of constituents or are used only for water-level measurements. 
New wells are constructed to maintain the integrity of the monitoring well borehole and prevent cross contamination from the surface or other zones into the aquifer. The well casing isolates the sampled interval of the well from the vadose zone and nonsampled intervals of the aquifer. Screens are used to filter out solids and enhance collection of representative groundwater samples from the aquifer. All new wells meet the requirements of WAC 173-160. Groundwater monitoring wells are located, designed, and constructed based on data quality objectives and criteria established in groundwater monitoring plans.

Groundwater monitoring wells require periodic maintenance to ensure that representative samples are obtained. Wells are typically scheduled for routine inspection and maintenance every 3 to 5 years. Where a dedicated pump is installed, the pump is inspected and tested. A downhole video survey is then performed to verify integrity of the casing. The inside of the casing is usually brushed to remove deposits before replacing the pump. Nonroutine well maintenance may be scheduled when a problem is identified during sampling.

\section{Hydrologic Characterization and Modeling}

Hydrologic characterization activities are conducted to gain understanding of hydrogeologic conditions and controls on groundwater and contaminant movement. Characterization activities include geologic sampling, geophysical logging of boreholes, and hydraulic and tracer testing of wells to determine aquifer-flow and -transport properties. These activities are directed toward developing site-specific and regional hydrogeologic models of the Hanford Site. A three-dimensional, multilayer, numerical, groundwater model of the unconfined aquifer has been constructed in conjunction with characterization. The model is used to predict the movement of groundwater and contaminants under present and future Hanford Site conditions. Other modeling activities support groundwater-remediation and wastemanagement activities.

\section{Water-Level Monitoring}

The Hanford Groundwater Monitoring Project measures water levels to help characterize the direction and velocity of groundwater flow, to determine the impact of Hanford Site operations on the groundwater-flow system, and to assess the ability to detect groundwater impacts from specific monitored facilities. Water-level monitoring activities are described in the Water-Level Monitoring Plan (PNNL-13021). Routine water-level measurements in the unconfined aquifer are made annually to construct a sitewide water-table map and to determine flow directions in the vicinity of facilities that require groundwater monitoring. Water-table maps are published in annual groundwater monitoring reports (e.g., PNNL-13116 for 1999). The sitewide water-level information for the unconfined aquifer is used for the following:

- identifying recharge and discharge areas

- evaluating the influence of wastewater discharges on the direction of groundwater flow

- assessing the interaction between groundwater and surface water bodies

- assessing the interaction between groundwater in individual hydrogeologic units 
- determining the horizontal hydraulic gradient, which is needed to estimate the average linear velocity of groundwater flow and contaminant migration

- assessing the impact of groundwater pump-and-treat operations on local flow patterns

- improving the design of the monitoring well networks

- calibrating and verifying numerical groundwater flow models.

The distribution of hydraulic head in the upper basalt-confined aquifer system is also monitored to assess the potential for contaminants to migrate off the Hanford Site through this aquifer and to evaluate the hydraulic relationship between the unconfined aquifer and upper basalt-confined aquifer systems.

In addition to the annual regional water-level measurements, site-specific measurements are also collected. Annual, semiannual, or quarterly monitoring is conducted for most wells. Water levels are measured routinely in wells before any groundwater sampling is performed.

\section{Groundwater Sampling and Analysis}

The Hanford Groundwater Monitoring Project lists sampled wells in a separately published monitoring plan (e.g., PNNL-11989 for 2000). The distribution of unconfined-aquifer wells is shown in Figure III.B-1. The network changes slightly from year to year, depending on changing groundwater conditions and project requirements. Wells in the basalt-confined aquifer system are sampled less frequently and locations are shown in Figure III.B-2.

PNNL manages groundwater sampling and associated quality control (QC) procedures through annual statements of work to other contractors. The statements of work specify wells to be sampled, analytes, sampling frequencies, quality requirements, analytical and sampling procedures, and reporting requirements. Analysis of groundwater samples is managed through statements of work to commercial analytical laboratories. These statements of work specify analytical and QC reporting requirements pertaining to sample analysis.

The Hanford Groundwater Monitoring Project operates in accordance with a quality assurance plan that defines the controls, procedures, and documentation that are required. That plan implements the requirements of $10 \mathrm{CFR} 830.120$. Trained staff members collect samples according to written procedures. Samples are analyzed according to documented standard analytical procedures (SW-846). The quality of analytical data is verified by a continuing program of laboratory $\mathrm{QC}$, which consists of participation in interlaboratory crosschecks, replicate sampling and analysis, submittal of blind standard samples and blanks, and splitting samples with other laboratories. Letters of instruction are prepared as needed to meet specific program requirements. 


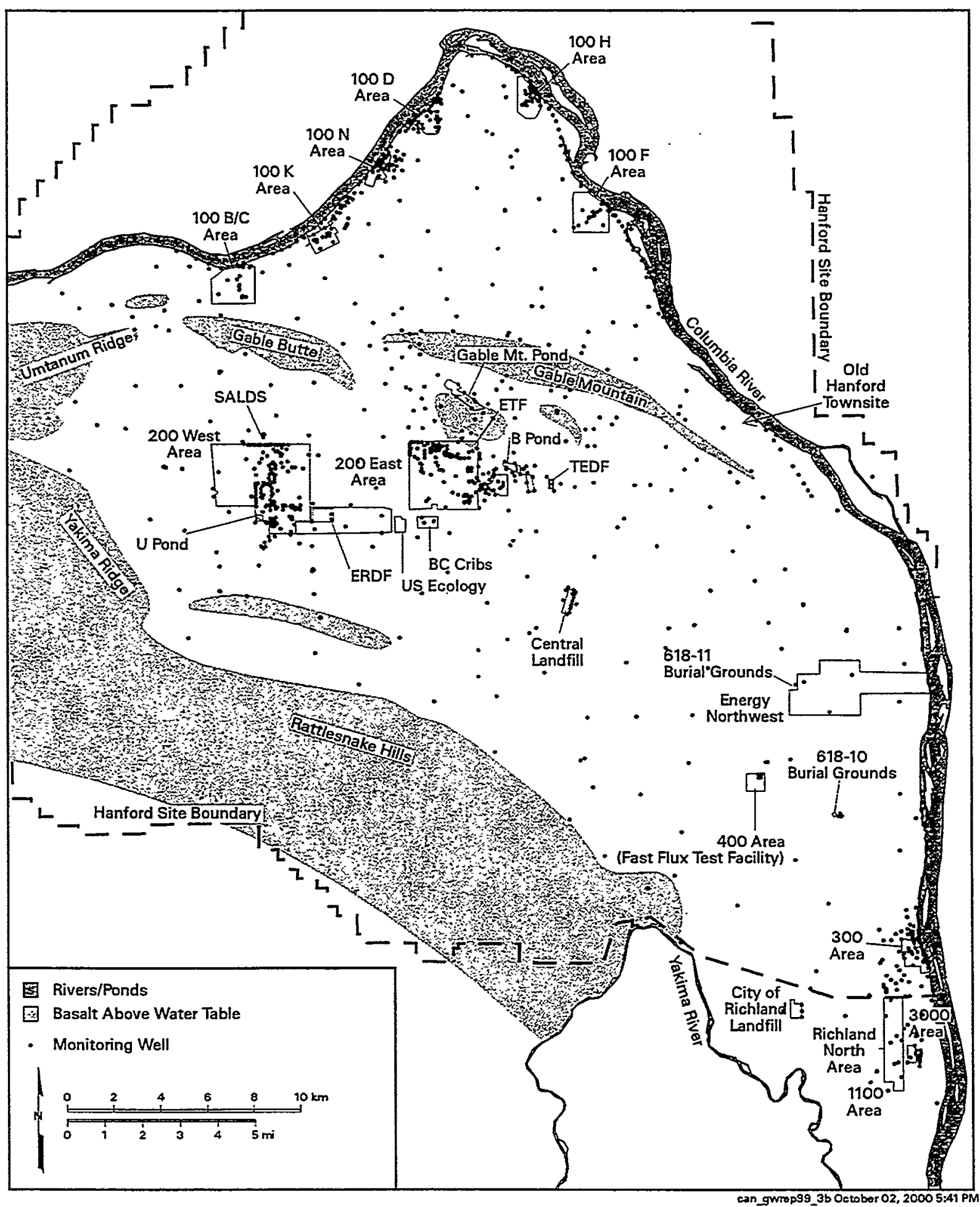

Figure III.B-1. Unconfined Aquifer Monitoring Wells 


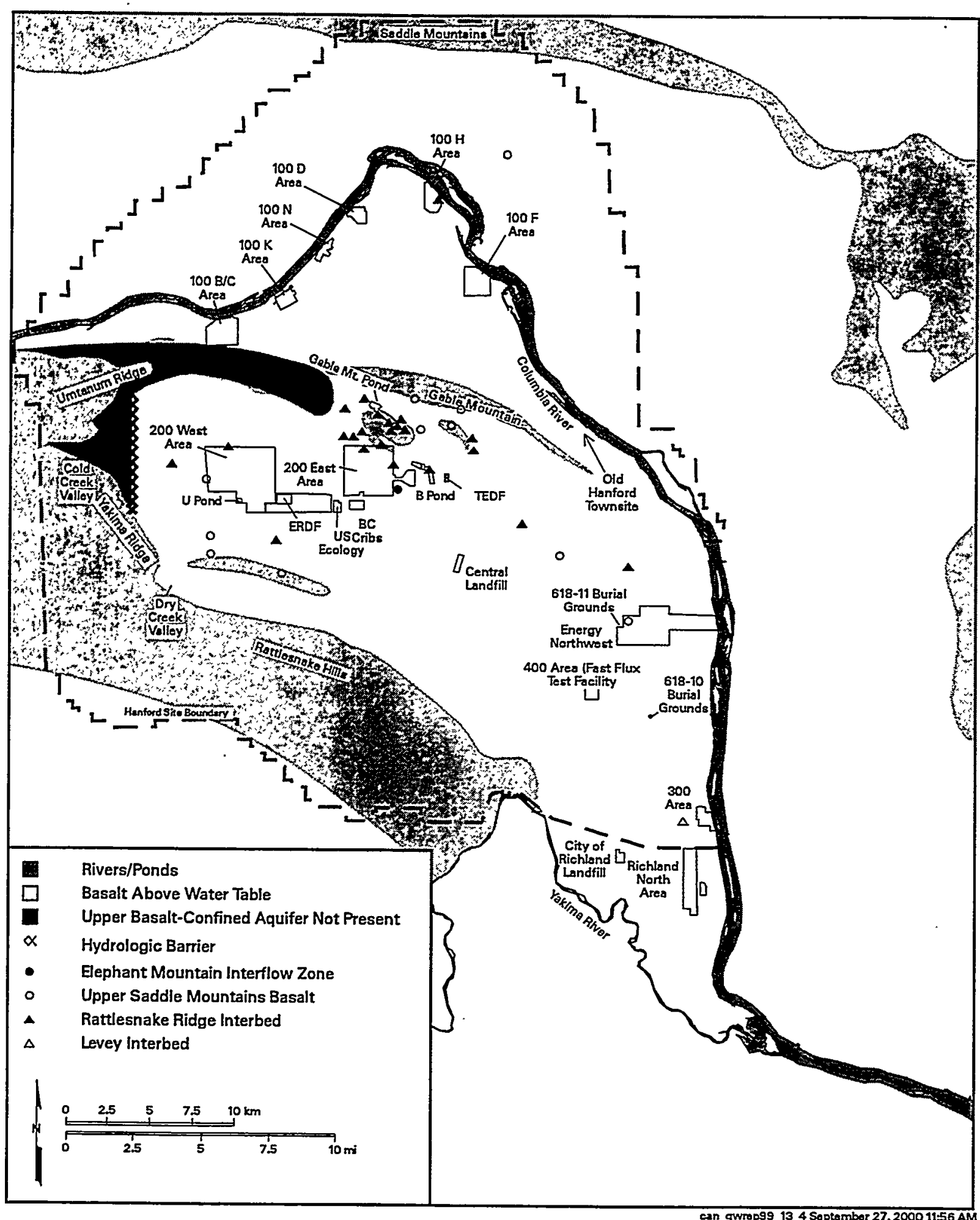

Figure III.B-2. Basalt-Confined Aquifer Monitoring Wells 
Data Quality Objectives. Data quality objectives are defined in the QC plan, an appendix of the quality assurance plan. As specified in the statements of work for sampling and analysis, all groundwater monitoring is assessed by the same set of quality procedures.

Five basic data quality criteria are applied: precision, accuracy, representativeness, completeness, and comparability, along with applicable project-specific quality parameters to evaluate the data and the laboratories analyzing the samples. Evaluation of the sampling and analysis results with respect to the five basic data quality criteria are summarized below.

- Precision is evaluated using data from laboratory duplicates, matrix spike duplicates, field duplicates, and blind samples.

- Accuracy is evaluated using data from laboratory matrix spikes; laboratory control samples; EPA water pollution, water supply, and interlaboratory performance evaluation programs; and blind samples.

- Representativeness expresses the degree to which facility groundwater monitoring data represent the real composition of the groundwater in the aquifer. Goals for data representativeness for groundwater monitoring programs are addressed qualitatively by the specification of well construction, sampling locations, sampling intervals, and sampling and analysis techniques identified in the groundwater monitoring plan for each RCRA facility.

- Completeness is defined as the percentage of measurements made that are judged to be valid. Completeness is determined by the number of data not flagged as invalid divided by the total number of data validated multiplied by 100 . The calculated percentages used in reporting completeness are conservative figures based on the number of results that might have been affected by missed holding times, laboratory contamination, or other QC problems.

- Comparability is used to ensure that samples analyzed by different laboratories or by the same laboratory over different time periods are comparable. Samples are analyzed in accordance with SW-846 and other applicable approved methods. Comparability of field measurements is maintained by following approved sampling procedures that ensure consistency among sampling events.

Limits for reporting, precision, accuracy, and completeness are presented in the QC plan. Sitespecific groundwater-monitoring or -assessment plans specify whether a particular site has more stringent data quality objectives than those specified in the QC plan.

Objectives for precision and accuracy for chemical analyses are based on criteria stipulated in the methodology (SW-846, EPA-600/4-79-020). Guidelines for precision and accuracy for chemical QC data are provided in the QC plan.

Required detection limits for chemical and radiological constituents are defined in the laboratory contract. For radiological constituents, reporting limits as low as one-third the derived 4-millirem 1-year effective dose equivalent are preferred but are not always achievable. Preferred reporting limits and actual reporting limits for radiological constituents are listed in the QC plan. For chemical constituents, 
detection limits as low as one-third of the EPA primary drinking water standards are preferred. In some cases, detection limits that are one-third of drinking water standards are not feasible (e.g., pentachlorophenol and cadmium). Because detection limits change frequently, these values are not provided in the QC plan.

QC Program. The QC program helps to ensure the reliability and validity of field and laboratory measurements conducted in support of the Hanford Groundwater Monitoring Project. QC practices are defined in the QC plan for the project. Field and laboratory QC components and reporting requirements are included in the plan. Laboratory QC includes analysis of method blanks, matrix spikes, matrix duplicates, matrix spike duplicates, surrogate spikes, and laboratory-control samples. Blind standards are also forwarded to the laboratory each quarter. The results from field and laboratory QC samples are evaluated to determine whether the contracted laboratories are performing satisfactorily.

\section{Data Management and Interpretation}

Groundwater data are managed using computer databases and hard-copy files. Water-level and analytical data are currently stored in the Hanford Environmental Information System (HEIS) computer database. Well logs, effluent data, hydraulic parameters, field/sampling records, hard-copy analytical results, and other related information are assembled and stored in project files by the contractors responsible for the work.

Data from wells that monitor waste disposal facilities are reviewed for compliance with applicable internal guidelines and state and federal regulations. If monitoring indicates that a facility is out of compliance, or that groundwater is being impacted, an investigation is initiated to determine the causes and evaluate remedial actions. The details of these types of investigations are discussed in later sections on monitoring at regulated units.

Interpretation activities include observing trends in contaminant concentrations of individual wells, mapping contaminant plumes, determining groundwater flow directions, computing aquifer properties such as hydraulic conductivity, compiling effluent source information, and modeling the groundwater system to make predictions. Interpretation results are documented in annual groundwater monitoring reports (e.g., PNNL-13116 for 1999) and in topical reports.

\section{Groundwater Monitoring Reports}

A comprehensive annual groundwater monitoring report (e.g., PNNL-13116 for 1999) summarizes all Hanford Site groundwater monitoring activities. That report discusses groundwater chemistry results and suspected sources of groundwater contaminants. Maps are provided for most of the groundwater contaminant plumes. Water-level maps for the unconfined and upper basalt-confined aquifer systems are also provided. Data are tabulated and included in an electronic format. A summary description of the QC program for sample analysis and a summary of the fiscal year's activities, together with the required statistical evaluations, are appended to the report.

Results of RCRA and other near-field monitoring are also included in the groundwater annual report. In addition to the annual report, quarterly RCRA letter reports, summarizing major findings for that quarter, are prepared and submitted to Ecology. The quarterly reports indicate that the data have been 
validated and made available electronically and include summaries of monitoring results for sites in assessment programs (see discussion below). The annual report provides an interpretive analysis of all the available data. For assessment-level RCRA monitoring, a report of the results of the groundwater quality assessment program must be submitted annually. This may be included in the annual groundwater report or issued as a separate report.

The annual report (e.g., PNNL-13116 for 1999) also summarizes groundwater monitoring activities at the Solid Waste Landfill as required by WAC 173-304, several sites monitored under WAC 173-216, and CERCLA. Special project reports are issued periodically that include pump-and-treat reports, data evaluation reports, journal articles, and presentations.

\section{Groundwater Monitoring at Regulated Units}

Facilities regulated under RCRA and other state laws are monitored 1) to comply with the intent of state and federal requirements, 2) to assess potential impact on groundwater quality, and 3) to provide an early warning of unexpected occurrences and trends. Ecology and EPA issued the Hanford Facility RCRA Part B Permit in September 1994 (Ecology 1994). In the permit, Ecology and EPA designated the Hanford Site as a single RCRA facility with over 60 individual liquid and solid waste TSD units. The Tri-Party Agreement (Ecology et al. 1998) recognized that all of the TSD units cannot be permitted simultaneously and set up a schedule to submit unit-specific Part B RCRA/dangerous waste permit applications and closure plans to Ecology and EPA. Of the 60 TSD units, 25 require groundwater monitoring to determine if operations are impacting the uppermost aquifer. The locations of these RCRA TSD units are shown in Figure III.B-3.

In addition to RCRA facilities, there are non-RCRA operational facilities on the Hanford Site that are regulated under the requirements of DOE Orders, state of Washington regulations, and the Tri-Party Agreement. These are disposal facilities that receive treated effluents from the 200 and 400 Areas. In December 1991, an agreement was reached to include all miscellaneous waste streams and/or any new waste stream discharges to the ground under the waste discharge permit system defined in WAC 173216. Groundwater monitoring is conducted at three of these sites: 400 Area Process Ponds, 200 Areas Treated Effluent Disposal Facility, and the State-Approved Land Disposal Site (see Figure III.B-3). The Solid Waste Landfill is another non-RCRA facility that requires groundwater monitoring. This disposal facility is not addressed under the Tri-Party Agreement. Current operations and groundwater monitoring conducted at the Solid Waste Landfill are regulated by WAC 173-304-490. Current groundwater monitoring plans for these four facilities are referenced in the annual groundwater monitoring reports (e.g., PNNL-13116 for 1999).

\section{RCRA Interim Status}

Interim status RCRA facilities are monitored under one of three phases: background monitoring, indicator parameter evaluation, or groundwater quality assessment. A groundwater monitoring plan for each RCRA facility describes the monitoring network, sampling and analysis procedures, analytes, and sampling frequency. 


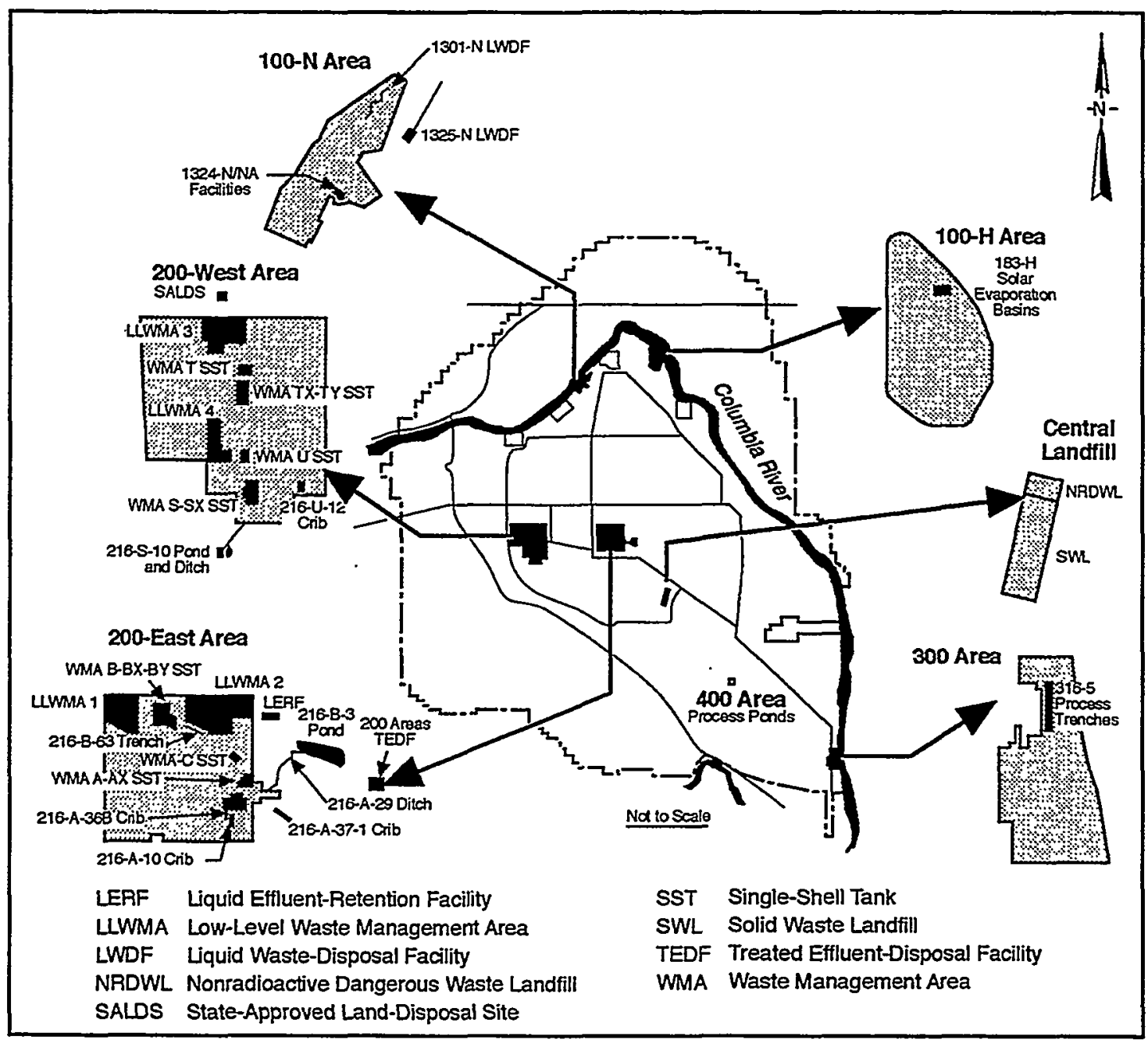

G00080088.3

Figure III.B-3. Hanford Site Facilities Requiring Groundwater Monitoring

As specified in 40 CFR 265, groundwater samples from all RCRA monitoring wells must be obtained and analyzed quarterly for 1 year to establish background concentrations for future data comparisons. Site-specific analytes (including radionuclides) are determined from evaluation of the waste stream or source associated with the facility. Additional site-specific constituents may be included to aid in tracking groundwater movement and the influence of other facilities. In some cases, the list of constituents from 40 CFR 264 Appendix IX is analyzed to establish a baseline for future comparisons. All of the RCRA facilities have completed their initial background monitoring phases.

After background levels of groundwater constituents are established, the indicator parameterevaluation program commences. Samples are collected semiannually to determine whether groundwater contamination from the facility is present. Sample data for the indicator parameters $\mathrm{pH}$, specific conductance, total organic carbon, and total organic halides are compared with background data. If a statistically significant change over background has occurred in a downgradient well, Ecology must be notified and a monitoring plan to assess groundwater quality must be prepared and implemented. That plan defines steps to be taken to determine if the facility is the contaminant source and, if so, to determine the magnitude and extent of the contamination. RCRA facilities under the groundwater quality assessment 
phase may require an expanded groundwater monitoring network and are monitored quarterly. Ecology may require corrective action through an administrative order if the results of the assessment indicate significant hazards to human health and the environment.

To determine whether a statistically significant change has occurred, the sample results from upgradient wells during the first year of monitoring are averaged, and summary statistics (mean, standard deviation, and coefficient of variation) are developed for each RCRA facility. Once the background summary statistics have been developed, the averaged-replicate t-test (OSWER-9950.1) is used to calculate the test statistic for each contaminant indicator parameter. The test statistic is reformulated in such a way that a critical mean can be obtained for each indicator parameter. These critical means have been adjusted to control the overall facility false-positive rate at $1 \%$, which is consistent with the performance standard required for RCRA facilities operated under interim status (40 CFR 265.93[b]).

\section{RCRA Final Status}

Site-specific groundwater monitoring requirements (e.g., well networks, analyte lists) for final status RCRA facilities are negotiated and included in the Hanford Facility RCRA Permit (Ecology 1994). These requirements are incorporated into the permit as site-specific groundwater monitoring plans, which are prepared according to the permit modification schedule. Facilities currently conducting final status groundwater monitoring and the date that current interim status facilities are scheduled to become final status were listed in Table III.B-1.

Three phases of groundwater monitoring are specified under final status regulations: detection monitoring, compliance monitoring, and corrective action.

In a detection monitoring program, groundwater sampling results from downgradient wells for parameters listed in the unit-specific groundwater monitoring plan are compared with those from background wells to determine whether there has been a statistically significant change from background concentrations. Statistical methods appropriate for a final-status detection-monitoring program include analysis of variance, tolerance intervals, prediction intervals, control charts, test of proportions, or other statistical methods approved by Ecology. The distribution(s) of monitoring parameters; the nature of the data; the proportions of nondetections; and seasonal, temporal, and spatial variations are important factors to consider when selecting appropriate statistical methods. The statistical evaluation procedures chosen are based on PB89-151047, EPA/530-R-93-003, and ASTM (1996). Specifics are addressed in the unit-specific permit applications.

A compliance groundwater monitoring program is established if detection monitoring reveals a statistically significant change in an indicator parameter. The objective of compliance-level monitoring is to determine if the monitored facility is in compliance with groundwater protection standards. This is accomplished by comparing the concentrations of constituents of concern to groundwater protection standards such as the risk-based maximum concentration limit; an alternate concentration limit; natural background; or applicable, relevant, and appropriate requirements. 
Table M.B-1. Hanford Site Interim and Final Status Groundwater Monitoring Projects (as of September 1, 2000)

\begin{tabular}{|c|c|c|c|c|c|c|}
\hline \multirow[b]{2}{*}{$\begin{array}{l}\text { TSD Unit, Date } \\
\text { Initiated } \\
\end{array}$} & \multicolumn{2}{|c|}{$\begin{array}{l}\text { Interim Status TSD Unit Groundwater } \\
\text { Monitoring } \\
\end{array}$} & \multicolumn{2}{|c|}{$\begin{array}{l}\text { Final Status TSD Unit } \\
\text { Groundwater Monitoring }\end{array}$} & \multirow[b]{2}{*}{$\begin{array}{c}\text { Associated } \\
\text { (CERCLA) } \\
\text { Groundwater } \\
\text { Operable Units } \\
\end{array}$} & \multirow[b]{2}{*}{$\begin{array}{c}\text { Year } \\
\text { Scheduled for } \\
\text { Part B or } \\
\text { Closure } \\
\end{array}$} \\
\hline & $\begin{array}{c}\text { Indicator } \\
\text { Parameter } \\
\text { Evaluation }^{(\mathrm{a})} \\
\end{array}$ & $\begin{array}{c}\text { Groundwater } \\
\text { Quality } \\
\text { Assessment, Date } \\
\text { Initiated } \\
\end{array}$ & $\begin{array}{c}\text { Detection } \\
\text { Evaluation } \\
\end{array}$ & $\begin{array}{c}\text { Corrective } \\
\text { Action, } \\
\text { Date } \\
\text { Initiated } \\
\end{array}$ & & \\
\hline $\begin{array}{l}\text { 183-H Solar } \\
\text { Evaporation } \\
\text { Basins, June } 1985\end{array}$ & & & & $\mathrm{X}, 1998$ & $100-H R-3$ & $1994^{(b)}$ \\
\hline $\begin{array}{l}\text { 1301-N LWDF, } \\
\text { December } 1987\end{array}$ & & & $\mathrm{X}^{(\mathbf{c})}$ & & $100-N R-2$ & $1999^{(b)}$ \\
\hline $\begin{array}{l}\text { 1324-N/NA Pond, } \\
\text { December } 1987\end{array}$ & & & $\mathrm{X}^{(\mathrm{c})}$ & & $100-N R-2$ & $1999^{(b)}$ \\
\hline $\begin{array}{l}\text { 1325-N LWDF, } \\
\text { December } 1987\end{array}$ & & & $X^{(c)}$ & & $100-N R-2$ & $1999^{(b)}$ \\
\hline $\begin{array}{l}\text { 216-B-3 Pond, } \\
\text { November } 1988\end{array}$ & $X$ & & & & 200-PO-1 & $2003^{(b)}$ \\
\hline $\begin{array}{l}\text { 216-A-29 Ditch, } \\
\text { November } 1988\end{array}$ & $X$ & & & & 200-PO-1 & $2003^{(b)}$ \\
\hline $\begin{array}{l}\text { PUREX Plant } \\
\text { Cribs, },{ }^{(d)} 1988\end{array}$ & & X, 1997 & & & 200-PO-1 & $>2003^{(b)}$ \\
\hline $\begin{array}{l}216-B-63 \text { Trench, } \\
\text { August } 1991\end{array}$ & $\mathrm{X}$ & & & & $200-\mathrm{PO}-1$ & $2003^{(b)}$ \\
\hline $\begin{array}{l}216-S-10 \text { Pond, } \\
\text { August } 1991\end{array}$ & $x$ & & & & & $2003^{(b)}$ \\
\hline $\begin{array}{l}\text { 216-U-12 Crib, } \\
\text { September } 1991\end{array}$ & & $X, 1993$ & & & 200-UP-1 & $>2003^{(b)}$ \\
\hline LERF, July 1991 & & & $X^{(e)}$ & & & $1998^{(\mathfrak{n})}$ \\
\hline $\begin{array}{l}\text { LLBG WMA-1, } \\
\text { September } 1988\end{array}$ & $\mathrm{X}$ & . & & & . & $\mathrm{TBD}^{\left(\mathrm{f}_{\mathrm{g}}\right)}$ \\
\hline $\begin{array}{l}\text { LLBG WMA-2, } \\
\text { September } 1988\end{array}$ & $\mathrm{X}$ & & & & & $\mathrm{TBD}^{(\mathrm{f}, \mathrm{g})}$ \\
\hline $\begin{array}{l}\text { LLBG WMA-3, } \\
\text { October } 1988\end{array}$ & $X$ & & & & & $\mathrm{TBD}^{(\mathrm{f}, \mathrm{g})}$ \\
\hline $\begin{array}{l}\text { LLBG WMA-4, } \\
\text { October } 1988\end{array}$ & $\mathrm{X}$ & & & & 200-ZP-1 & $\mathrm{TBD}^{(\mathfrak{f}, \mathrm{g})}$ \\
\hline $\begin{array}{l}\text { WMA-A-AX SST, } \\
\text { February } 1990\end{array}$ & $\mathrm{x}$ & & & & & $>2003^{(b)}$ \\
\hline $\begin{array}{l}\text { WMA-B-BX-BY } \\
\text { SST, February } \\
1990\end{array}$ & & X, 1996 & & & & $>2003^{(b)}$ \\
\hline $\begin{array}{l}\text { WMA-C SST, } \\
\text { February } 1990\end{array}$ & $\mathrm{X}$ & & & & 200-PO-1 & $>2003^{(b)}$ \\
\hline
\end{tabular}


Table III.B-1. (contd)

\begin{tabular}{|c|c|c|c|c|c|c|}
\hline \multirow[b]{2}{*}{$\begin{array}{l}\text { TSD Unit, Date } \\
\text { Initiated }\end{array}$} & \multicolumn{2}{|c|}{$\begin{array}{l}\text { Interim Status TSD Unit Groundwater } \\
\text { Monitoring } \\
\end{array}$} & \multicolumn{2}{|c|}{$\begin{array}{c}\text { Final Status TSD Unit } \\
\text { Groundwater Monitoring } \\
\end{array}$} & \multirow[b]{2}{*}{$\begin{array}{c}\text { Associated } \\
\text { (CERCLA) } \\
\text { Groundwater } \\
\text { Operable Units } \\
\end{array}$} & \multirow[b]{2}{*}{$\begin{array}{c}\text { Year } \\
\text { Scheduled for } \\
\text { Part B or } \\
\text { Closure } \\
\end{array}$} \\
\hline & $\begin{array}{c}\text { Indicator } \\
\text { Parameter } \\
\text { Evaluation }^{(a)}\end{array}$ & $\begin{array}{l}\text { Groundwater } \\
\text { Quality } \\
\text { Assessment, Date } \\
\text { Initiated }\end{array}$ & $\begin{array}{l}\text { Detection } \\
\text { Evaluation }\end{array}$ & $\begin{array}{l}\text { Corrective } \\
\text { Action, } \\
\text { Date } \\
\text { Initiated }\end{array}$ & & \\
\hline $\begin{array}{l}\text { WMA-S-SX SST, } \\
\text { October 1991 }\end{array}$ & & X, 1996 & - & & 200-UP-1 & $>2003^{(b)}$ \\
\hline $\begin{array}{l}\text { WMA-T SST, } \\
\text { February } 1990\end{array}$ & & X, 1993 & & & $200-Z \mathrm{P}-1$ & $>2003^{(b)}$ \\
\hline $\begin{array}{l}\text { WMA-TX-TY } \\
\text { SST, September- } \\
\text { October } 1991\end{array}$ & & X, 1993 & & & $200-Z P-1$ & $>2003^{(b)}$ \\
\hline $\begin{array}{l}\text { WMA-U SST, } \\
\text { October } 1990\end{array}$ & & $X, 2000$ & & & $200-Z P-1$ & $>2003^{(b)}$ \\
\hline $\begin{array}{l}\text { 316-5 Area } \\
\text { Process Trenches, } \\
\text { June } 1985\end{array}$ & & & & $X, 1996^{(\mathrm{h})}$ & $300-F F-5$ & $1996^{(b)}$ \\
\hline $\begin{array}{l}\text { NRDWL, October } \\
1986\end{array}$ & $\mathrm{x}$ & & & & 200-PO-1 & $>2003^{(b)}$ \\
\hline
\end{tabular}

(a) Specific parameters ( $\mathrm{pH}$, specific conductance, total organic carbon, and total organic halides) used to determine if a facility is affecting groundwater quality. Exceeding the established limits means that additional evaluation and sampling are required (groundwater quality assessment). An $\mathrm{X}$ in the column indicates whether an evaluation was needed or an assessment was required.

(b) Closure/postclosure plan; TSD unit will close under final status.

(c) Monitored according to interim status plan as specified in closure plans.

(d) 216-A-10, 216-A-36B, and 216-A-37-1 Cribs.

(e) Monitored according to interim status plan until final plan approved.

(f) Part B permit; TSD unit will operate under final status regulations beginning in year indicated.

(g) To be decided.

(h) Monitored according to compliance plan until corrective action plan approved.

CERCLA = Comprehensive Environmental Response, Compensation, and Liability Act of 1980.

LERF = Liquid effluent retention facility.

LLBG = Low-level burial ground.

LWDF = Liquid waste disposal facility.

NRDWL $=$ Nonradioactive Dangerous Waste Landfill.

RCRA = Resource Conservation and Recovery Act of 1976.

SST = Single-shell tanks.

TSD $\quad=$ Treatment, storage, or disposal.

WMA $=$ Waste management area.

$>\quad=$ Beyond the year 2003. 
Maximum concentration limits are identified for each of the groundwater monitoring parameters listed in Table 1 of WAC 173-303-645. Alternate concentration limits may be proposed after considering the observed concentrations of chemical constituents in the groundwater that might originate from the regulated unit in question. The area background, natural background, and other standards and requirements that are applicable, relevant, and appropriate are evaluated when proposing an alternate concentration limit.

If, during compliance-level monitoring, the referenced concentration limit(s) for a given groundwater parameter(s) is significantly exceeded, a corrective action program is developed and implemented to protect human health and the environment. Details for the corrective action program are specified in the unit-specific permit applications or closure plans. Additionally, a groundwater monitoring plan used to assess the effectiveness of the corrective action measures is submitted. That monitoring plan is similar in scope to the compliance-level groundwater monitoring program and includes all relevant information pertaining to the location and description of monitoring wells, monitoring network, well construction and development, sampling and analysis plans, statistical methods, and quality procedures.

Under final status regulations, all wells at each TSD unit must be sampled at least semiannually. Two sampling procedures are allowed: a sequence of at least four samples is taken over a time interval that ensures, to the greatest extent technically feasible (default sampling procedure), that an independent sample is obtained or an alternate sampling procedure approved by the regulator(s) that is protective of human health and the environment (40 CFR 264.97, WAC 173-303-645). Specific sampling frequencies and statistical evaluation methods are provided in the unit-specific groundwater monitoring plan.

\section{CERCLA Past-Practice/RCRA Corrective Action Groundwater Monitoring}

Groundwater monitoring is conducted to support the CERCLA past-practice and RCRA corrective action characterization and remediation activities at.inactive sites. For the purpose of conducting these activities, the waste sites (called past-practice sites) and associated contaminated groundwater have been grouped into operable units. There are 74 source (waste site) and 11 groundwater operable units. Groundwater operable units are linked to numerous source operable units, which may have contributed to regional plumes of contamination but are treated separately from the source units for remediation. The locations of the groundwater operable units are shown on Figure III.B-4:

The operable units are designated as either RCRA past-practice units or CERCLA past-practice units. This designation ensures that only one past-practice program is applied to each operable unit. The same groundwater-monitoring activities are conducted at the operable units regardless of the applicable regulatory past-practice program.

Characterization phase monitoring is performed to support decisions leading to a record of decision or permit modification for the operable unit. Surveillance phase monitoring is conducted to meet the objectives of the final record of decision or permit modification issued for the operable unit. One operable unit (1100-EM-1) has received a final record of decision (ROD.1993), which requires surveillance phase monitoring. Maintenance phase monitoring is conducted at operable units where characterization monitoring has been completed but the record of decision or permit modification has not yet been 


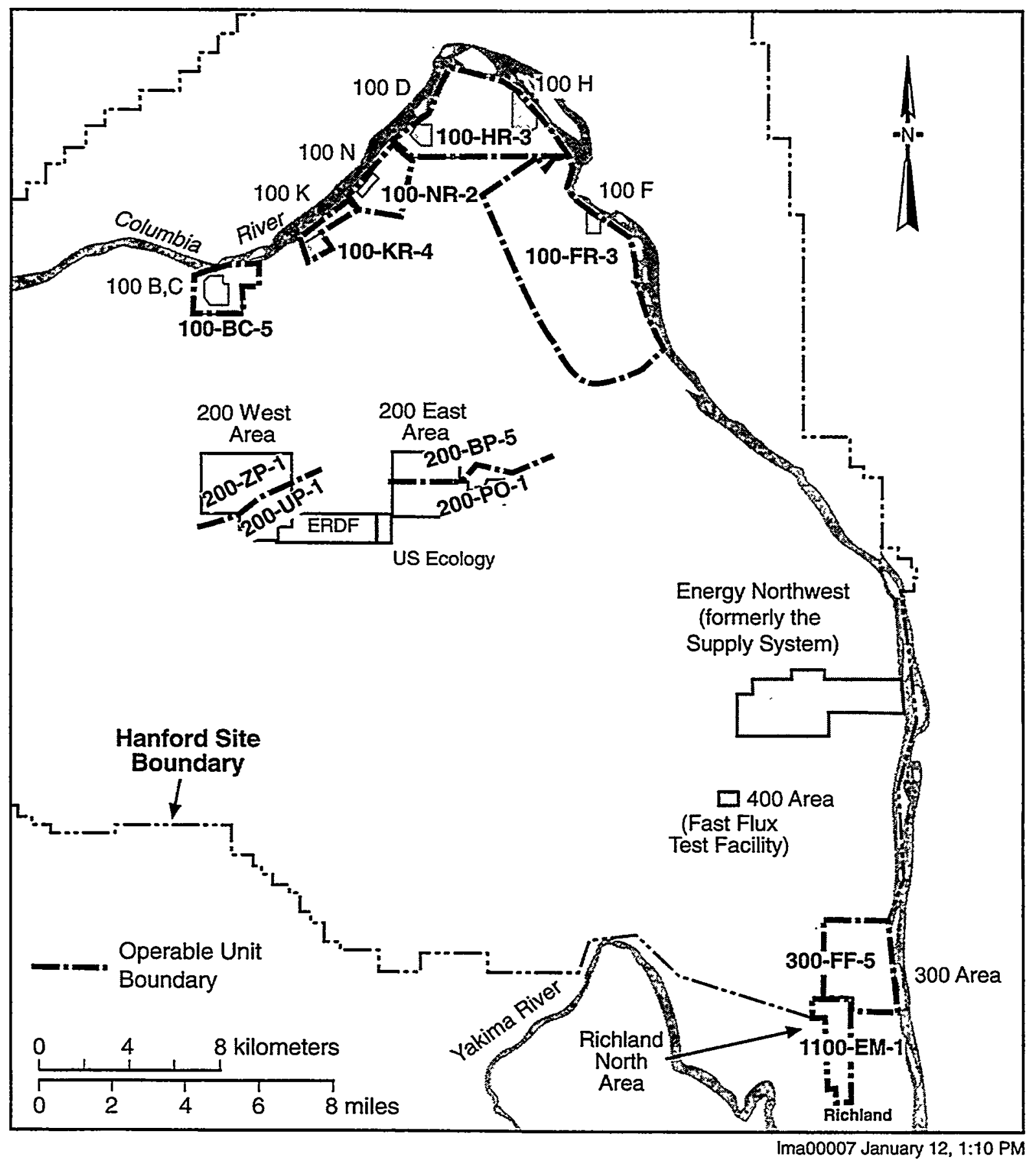

Figure III.B-4. Groundwater Operable Units on the Hanford Site

issued. Maintenance phase monitoring is also conducted at sites where an interim record of decision or expedited response action is in effect. As of September 2000, characterization monitoring is complete but permit modifications have not been issued for operable units 100-BC-5, 100-FR-3, 200-BP-5, and 200-PO-1. Requirements for maintenance-phase monitoring at these sites is specified in letters to Ecology that are part of the administrative record. Operable units where an interim record of decision has been issued include 200-UP-1 (ROD 1997), 200-ZP-1 (ROD 1995), 300-FF-5 (ROD 1996a), 100-HR-3 and 100-KR-4 (ROD 1996b, 1999a). An expedited response action is being conducted at 
operable unit 100-NR-2 (ERA 1994, ROD 1999b). Characterization, maintenance, and surveillance phase monitoring conducted at these sites also meet the objectives of DOE Order 5400.1.

Additional groundwater monitoring is conducted outside of but consistent with this Environmental Monitoring Plan. This type of monitoring is focused strictly on evaluating the performance of groundwater remediation activities at an expedited response action site (100-NR-2) and at interim record of decision sites (100-HR-3, 100-KR-4, 200-UP-1, and 200-ZP-1).

A listing of the groundwater operable units, the regulatory classification, the current status of each relative to record of decision/RCRA permit modification, and the general category of environmental monitoring is given in Table III.B-2.

\section{Sitewide Environmental Surveillance of Groundwater}

Additional sitewide monitoring of groundwater is required to meet the environmental surveillance program objectives stated in DOE Order 5400.1 and described in DOE/EH-0173T. The primary objectives addressed by sitewide groundwater monitoring are the following:

- evaluating the existing and potential offsite impact of groundwater contaminants from the Hanford Site

- providing an integrated interpretation of groundwater quality

Table III.B-2. Groundwater Operable Unit Summary - Environmental Monitoring

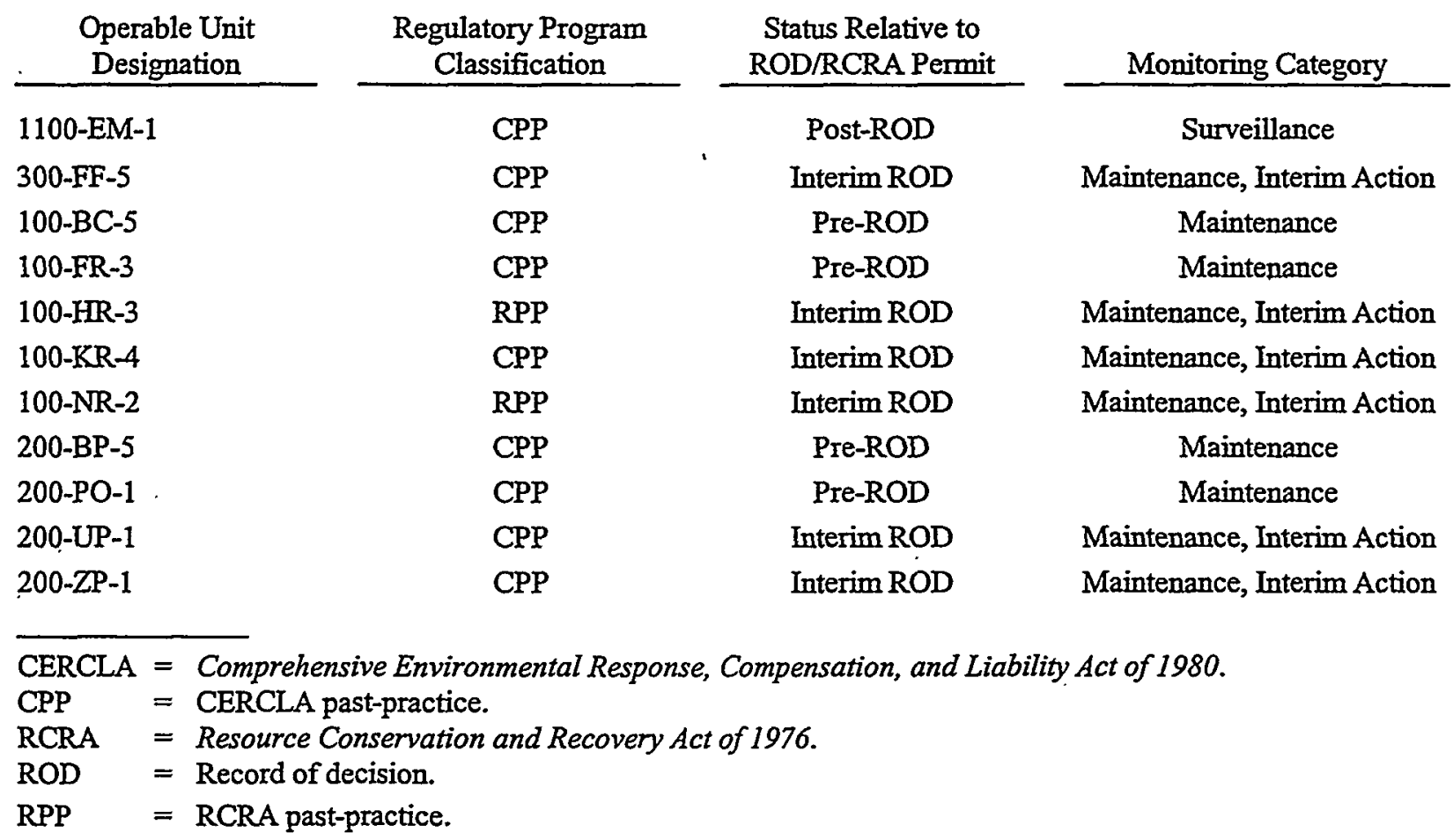


- identifying existing and potential groundwater contaminant sources

- characterizing and defining hydrogeologic, physical, and chemical trends in the sitewide groundwater system

- establishing baselines of groundwater quality

- assessing existing and emerging groundwater quality problems.

The Hanford Groundwater Monitoring Project tracks the movement of existing widespread contaminant plumes and conducts flow-system characterization and modeling to predict future plume movement. These activities allow actual and potential impacts to offsite water users to be evaluated. This section identifies the rationale and design criteria for sitewide monitoring of radiological and chemical contaminants in groundwater.

Data from near-field and operable unit monitoring (e.g., RCRA, CERCLA) of groundwater near specific facilities are integrated with information from the sitewide monitoring network. Data from wells that supply water to the Fast Flux Test Facility water system are also used in the sitewide interpretation. The sitewide monitoring network is designed to supplement these data to meet the objectives listed above. Additional wells selected for sampling each year generally fall into the following categories:

- contaminant source areas - Source areas include regions with active waste disposal facilities or with facilities that have generated or received waste in the past. These data are generally provided by facility-specific monitoring networks. However, additional wells may be identified to characterize contaminant sources and to supplement the site-specific monitoring networks.

- known contaminant plumes - Wells located within known contaminant plumes are monitored to characterize and define trends in the concentrations of radiological or chemical constituents. These wells are also monitored to meet the objective to quantify existing groundwater quality problems and to provide a baseline of environmental conditions against which future changes can be assessed.

- near water supplies - Water-supply wells on and near the site including those at the Fast Flux Test Facility and those used by the city of Richland, potentially provide a route for human exposure to contaminants in groundwater. Wells near these water supplies and, in some cases, the water supply wells themselves, are monitored to identify the potential impact to water quality.

- near Columbia River - Wells and sampling tubes near the Columbia River are monitored to assess the quality of groundwater as it leaves the unconfined aquifer. The Columbia River provides a pathway for contaminants to leave the Hanford Site and potentially enter a drinking water supply. Fish and other wildlife could also be exposed to contaminants at the Columbia River. Data from this area help evaluate existing and potential offsite impacts of groundwater contaminants, establish a baseline of groundwater quality, and assess existing and emerging groundwater quality problems. 
- vertical distribution of contaminants - The Hanford Groundwater Monitoring Project samples wells completed in the basalt-confined aquifer and deep in the Hanford-Ringold sediment to assess the depth of contamination.

- performance assessment - The environmental restoration contractor (i.e., Bechtel Hanford, Inc.) conducts performance assessment monitoring in conjunction with groundwater remedial actions. The groundwater project provides independent assessment of remedial actions.

- offsite - Groundwater is utilized as a source for domestic and agricultural water outside the Hanford Site. Offsite wells may be monitored periodically to ensure that contaminants from Hanford Site sources are not present and to maintain a baseline of information on offsite water quality.

- background areas - Wells in areas upgradient from Hanford Site operations are sampled to provide information on background groundwater quality. These data are needed to assess the impact of site operations on groundwater and also to identify contaminants contributed by offsite upgradient sources.

Wells planned for sampling and constituents to be analyzed during each fiscal year are published in a separate monitoring plan (e.g., PNNL-1 1989 for 2000). Results of sitewide groundwater monitoring are discussed in annual groundwater reports (e.g., PNNL-13116 for 1999). Figure II.B-1 showed the distribution of wells sampled recently for the unconfined aquifer system. Wells completed in the upper basalt-confined aquifer system are sampled to monitor groundwater conditions and the movement of contaminants found in this aquifer near the 200 Areas (see Figure III.B-2). The monitoring well network changes from year to year based on groundwater flow conditions, movement of contaminant plumes, and project objectives.

Analytes for the sitewide monitoring network wells are selected based on the constituents present in nearby plumes and the inventories of potential groundwater contaminants at upgradient sources. Sampling frequencies vary from monthly to less than annually based on observed plume movements and expected changes in constituent concentrations.

\section{Exceptions}

No exceptions have been taken to "should*" statements in DOE/EH-0173T.

\section{References}

ASTM (American Society for Testing and Materials). 1996. Provisional Standard Guide for Developing Appropriate Statistical Approaches for Ground-Water Detection Monitoring Programs. PS 64-96, West Conshohocken, Pennsylvania.

10 CFR 830.120, Code of Federal Regulations, Title 10, Part 830, Chapter 120. Nuclear Safety Management, Quality Assurance Requirements. 
40 CFR 264, Code of Federal Regulations, Title 40, Part 264. Standards for Owners and Operators of Hazardous Waste Treatment, Storage, and Disposal Facilities.

40 CFR 265, Code of Federal Regulations, Title 40, Part 265. Interim Status Standards for Owners and Operators of Hazardous Waste Treatment, Storage, and Disposal Facilities.

40 CFR 300, Code of Federal Regulations, Title 40, Part 300. National Oil and Hazardous Substances Pollution Contingency Plan.

40 CFR 300, Code of Federal Regulations, Title 40, Part 300, Appendix B. National Priorities List.

Comprehensive Environmental Response, Compensation, and Liability Act of 1980, as amended, Public Law 96-510, 94 Stat. 2767, 42 USC 9601 et seq.

DOE/EH-0173T. 1991. Environmental Regulatory Guide for Radiological Effluent Monitoring and Environmental Surveillance. Assistant Secretary for Environment, Safety and Health, U.S. Department of Energy, Washington, D.C.

DOE Order 5400.1. "General Environmental Protection Program."

DOE Order 5400.5. "Radiation Protection of the Public and the Environment."

DOE Order 5820.2A. "Radioactive Waste Management."

DOE/RL-89-12, Rev. 2. 1995. Hanford Site Ground-Water Protection Management Plan. D. B. Barnett, J. S. Schmid, S. S. Lowe, W. L. Allen, N. A. Ballantyne, C. H. Dohrer, M. J. Hartman, F. N. Hodges, D. G. Horton, V. G. Johnson, K. L. Lueck, D. J. Ortiz, A. J. Knepp, B. H. Ford, S. P. Hope, D. K. Tyler, R. D. Hildebrand, D. E. Olson, R. E. Peterson, G. L. Kasza, D. A. Myers, S. P. Luttrell, P. D. Thorne, and K. R. Moser, U.S. Department of Energy, Richland Operations Office, Richland, Washington.

Ecology - Washington State Department of Ecology. 1994. Hanford Facility RCRA Permit. Permit WA7890008967, effective September 28, 1994, Olympia, Washington.

Ecology - Washington State Department of Ecology, U.S. Environmental Protection Agency, and U.S. Department of Energy. 1998. Hanford Federal Facility Agreement and Consent Order. Document No. 89-10, Rev. 5 (The Tri-Party Agreement), Olympia, Washington.

EPA/530-R-93-003. 1992. Statistical Analysis of Ground-Water Monitoring Data at RCRA Facilities Addendum to Interim Final Guidance (Draft). U.S. Environmental Protection Agency, Washington, D.C.

EPA-600/4-79-020. 1983. Methods for Chemical Analysis of Water and Wastes. U.S. Environmental Protection Agency, Cincinnati, Ohio. 
ERA (Expedited Response Action). 1994. Action Memorandum: N Springs Expedited Response Action Cleanup Plan, U.S. Department of Energy Hanford Site, Richland WA. Washington State Department of Ecology, Olympia, Washington to U.S. Department of Energy, Richland, Washington.

OSWER-9950.1. 1986. Resource Conservation and Recovery Act (RCRA) Groundwater Monitoring Technical Enforcement Guidance Document. U.S. Environmental Protection Agency, Washington, D.C.

PB89-151047. 1989. Statistical Analysis of Ground-Water Monitoring Data at RCRA Facilities Interim Final Guidance. U.S. Environmental Protection Agency, Washington, D.C.

PNNL. 2000. In Standards-Based Management System (accessed online on November 1, 2000). Available URL: http://sbms/ch00d010.htm

PNNL-11989, Rev. 2. 2000. Integrated Monitoring Plan for the Hanford Groundwater Monitoring Project. M. J. Hartman, P. E. Dresel, J. W. Lindberg, D. R. Newcomer, and E. C. Thomton. Pacific Northwest National Laboratory, Richland, Washington.

PNNL-13021. 1999. Water-Level Monitoring Plan for the Hanford Groundwater Monitoring Project. J. P. McDonald, M. A. Chamness, and D. R. Newcomer. Pacific Northwest National Laboratory, Richland, Washington.

PNNL-13116. 2000. Hanford Site Groundwater Monitoring for Fiscal Year 1999. M. J. Hartman, L. F. Morasch, and W. D. Webber (eds.). Pacific Northwest National Laboratory, Richland, Washington.

Resource Conservation and Recovery Act of 1976, as amended, Public Law 94-580, 90 Stat. 2795, 42 USC 6901 et seq.

ROD (Record of Decision). 1993. Record of Decision, USDOE Hanford 1100 Area, Hanford Site, Richland, Washington. Washington State Department of Ecology, U.S. Environmental Protection Agency, and U.S. Department of Energy, Richland Operations Office, Richland, Washington.

ROD (Record of Decision). 1995. Declaration of the Record of Decision, USDOE Hanford 200 Area, Hanford Site, Benton County, Washington (200-ZP-1). Washington State Department of Ecology, U.S. Environmental Protection Agency, and U.S. Department of Energy, Richland Operations Office, Richland, Washington.

ROD (Record of Decision). 1996a. Declaration of the Record of Decision for the 300-FF-1 and 300-FF-5 Operable Units. Washington State Department of Ecology, U.S. Environmental Protection Agency, and U.S. Department of Energy, Richland Operations Office, Richland, Washington.

ROD (Record of Decision). 1996b. Declaration of the Record of Decision, USDOE Hanford 100 Area, 100-HR-3 and 100-KR-4 Operable Units, Hanford Site, Benton County, Washington, April 1996. Washington State Department of Ecology, U.S. Environmental Protection Agency, and U.S. Department of Energy, Richland Operations Office, Richland, Washington. 
ROD (Record of Decision). 1997. Declaration of the Record of Decision, U.S. DOE Hanford 200 Area, Hanford Site, Benton County, Washington (200-UP-1). Washington State Department of Ecology, U.S. Environmental Protection Agency, and U.S. Department of Energy, Richland Operations Office, Richland, Washington.

ROD (Record of Decision). 1999a. Amended Record of Decision, Decision Summary and Responsiveness Summary for the 100-HR-3 Operable Unit. U.S. Environmental Protection Agency, Region X, Seattle, Washington.

ROD (Record of Decision). 1999b. Interim Remedial Action Record of Decision for the 100-NR-1 and -NR-2 Operable Units of the Hanford 100-N Area. Washington State Department of Ecology, Olympia, Washington.

Superfund Amendments and Reauthorization Act of 1986, as amended, Public Law 99-499, 100 Stat. 1613, 42 USC 11001 et seq.

SW-846. 1986. Test Methods for Evaluating Solid Wastes: Physical/Chemical Methods, 3rd ed. Office of Solid Waste and Emergency Response, U.S. Environmental Protection Agency, Washington, D.C.

WAC 173-160, Washington Administrative Code. Minimum Standards for Construction and Maintenance of Wells. Olympia, Washington.

WAC 173-216, Washington Administrative Code. State Waste Discharge Program. Olympia, Washington.

WAC 173-303, Washington Administrative Code. Dangerous Waste Regulations. Olympia, Washington.

WAC 173-303-645, Washington Administrative Code. Releases from Regulated Units. Olympia, Washington.

WAC 173-304, Washington Administrative Code. Minimum Functional Standards for Solid Waste Handling. Olympia, Washington.

WAC 173-304-490, Washington Administrative Code. Ground Water Monitoring Requirements. Olympia, Washington. 


\title{
Hanford Site Environmental Monitoring Plan
}

\author{
Section III.C. Meteorological Monitoring
}

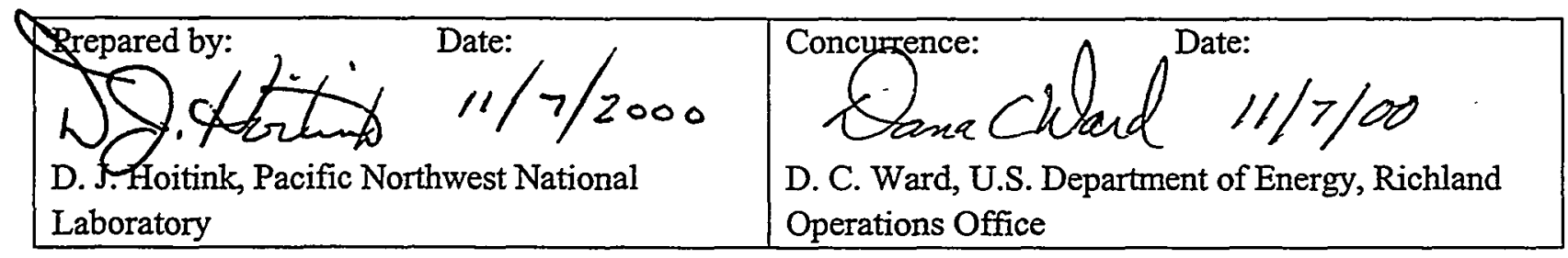




\section{Introduction}

Meteorological monitoring is another aspect of the U.S. Department of Energy's (DOE's) requirements for environmental monitoring and is designed to meet the environmental and meteorological monitoring program objectives stated in DOE Order 5400.1 and described in DOE/EH-0173T. This section identifies the data required to support environmental monitoring and other meteorological conditions important to these activities. Also, a meteorological information/monitoring program has been developed and is reported on annually (e.g., PNNL-13117 for 1999).

DOE/EH-0173T details the specific requirements of a meteorological monitoring program and addresses the following considerations:

- meteorological program basis

- meteorological data for dose assessment calculations

- meteorological measurements

- inspection, maintenance, and calibration

- data summarization and archiving

- quality assurance.

This section discusses the composition of the Hanford Site meteorological monitoring program as it relates to DOE Order 5400.1 and DOE/EH-0173T.

\section{Meteorological and Climatological Services Project}

The Pacific Northwest National Laboratory (PNNL) Meteorological and Climatological Services Project provides the DOE field offices and Hanford Site contractors with meteorological and climatological support for emergency response, weather forecasting, climatological data, and related special requests through the operation of the Hanford Meteorology Station. The project responds to Hanford Site needs through a program that includes the following:

- extensive data acquisition through a sitewide meteorological monitoring network

- site-specific forecasts, using weather satellite imagery and National Weather Service products

- standard hourly surface weather observations and 6-hour synoptic observations

- climatological data through monthly and annual summaries (e.g., PNNL-13117 for 1999), meteorological input to annual environmental reports (e.g., PNNL-13230 for 1999), and responses to ad hoc requests. 


\section{Meteorological Monitoring Network}

The Hanford Site covers an area with significant variations in topography and with elevations ranging from approximately 100 to nearly 1,100 meters above sea level. To characterize the meteorological conditions on and around the Hanford Site, 30 monitoring stations have been installed onsite and nearby offsite (Table III.C-1 and Figure III.C-1). Station locations were selected to reflect the influence of the varied topography, especially on wind speed and direction, and to provide appropriate data for atmospheric transport and diffusion modeling and for site characterization. The station selection process was based on an understanding of the effects of synoptic- and meso-scale meteorological events on wind flow over the Hanford Site and also from model studies of atmospheric transport that were run specifically to indicate areas where additional wind data were required. The meteorological monitoring network was designed to perform the following functions:

- to represent implicitly the effect of the varying topography of the Hanford Site on atmospheric circulations by strategic siting of the individual stations

- to monitor and collect real-time meteorological data at locations where operations are conducted that could have a possible negative impact in the event of an emergency

- to provide meteorological data for daily operational forecasting for Hanford Site activities

- to provide real-time meteorological data for atmospheric transport and diffusion modeling

- to provide climatological data for environmental assessments, environmental impact statements, facilities planning, etc.

A 124.3-meter tower, located at the Hanford Meteorology Station, has instruments at multiple levels to measure wind speed and direction and temperature. This tower has been used to collect data since the mid-1940s. Three 61-meter monitoring stations, with instruments at multiple levels, are located in onsite areas where significant operations are conducted. These stations provide additional information necessary to atmospheric transport and diffusion models. Twenty-six 9.1-meter towers have instruments for wind speed and direction (at 9.1 meters) and temperature (at 1.5 meters). Most stations also record precipitation. Detailed descriptions of each meteorological monitoring site, including narrative and photographic depictions of the topography proximate to each, can be found in PNL-6684.

\section{Meteorological Instrumentation}

The meteorological instrumentation provides data, including wind speed and direction, temperature, vertical temperature difference, dew-point temperature, and precipitation. Other data are collected via the surface observation program, including sky condition, cloud type and amount, ceiling height, mixing depth, atmospheric pressure, weather and obstructions to visibility, relative humidity, and solar radiation (PNL-6509). 
Table III.C-1. Hanford Site Meteorological Monitoring Towers

\begin{tabular}{|c|c|c|c|c|}
\hline & e Number & Site Name & $\begin{array}{l}\text { Tower } \\
\text { Height, } \mathrm{m}\end{array}$ & Instrumentation \\
\hline & 1 & Prosser Barricade & 9.1 & WS, WD, T, P \\
\hline & 2 & Emergency Opperations Center & 9.1 & WS, WD, T, P \\
\hline & 3 & Army Loop Road & 9.1 & WS, WD, T, P \\
\hline & 4 & Rattlesnake Springs & 9.1 & WS, WD, T, P \\
\hline & 5 & Edna & 9.1 & WS, WD, T \\
\hline & 6 & 200-East Area & 9.1 & WS, WD, T, P, AP \\
\hline & 7 & 200-West Area & 9.1 & $\mathrm{WS}, \mathrm{WD}, \mathrm{T}, \mathrm{P}$ \\
\hline & 8 & Beverly & 9.1 & $\mathrm{WS}, \mathrm{WD}, \mathrm{T}, \mathrm{P}$ \\
\hline & 9 & Fast Flux Test Facility & 61 & $\mathrm{WS}, \mathrm{WD}, \mathrm{T}, \mathrm{TD}, \mathrm{DP}, \mathrm{P}, \mathrm{AP}$ \\
\hline & 10 & Yakima Barricade & 9.1 & $\mathrm{WS}, \mathrm{WD}, \mathrm{T}, \mathrm{P}, \mathrm{AP}$ \\
\hline & 11 & 300 Area & 61 & WS, WD, T, TD, DP, P, AP \\
\hline & 12 & Wye Barricade & 9.1 & WS, WD, T, P \\
\hline & 13 & $100-\mathrm{N}$ Area & 61 & WS, WD, T, TD, DP, P, AP \\
\hline & 14 & WNP-2 & 9.1 & $\mathrm{WS}, \mathrm{WD}, \mathrm{T}, \mathrm{P}$ \\
\hline & 15 & Franklin County & 9.1 & WS, WD, T \\
\hline & 16 & Gable Mountain & 9.1 & $\mathrm{WS}, \mathrm{WD}, \mathrm{T}$ \\
\hline & 17 & Ringold & 9.1 & $\mathrm{WS}, \mathrm{WD}, \mathrm{T}, \mathrm{P}$ \\
\hline & 18 & Richland Airport & 9.1 & WS, WD, T, AP \\
\hline & 19 & $\begin{array}{l}\text { 200-West (Plutonium Finishing } \\
\text { Plant) }\end{array}$ & 9.1 & $\mathrm{WS}, \mathrm{WD}, \mathrm{T}, \mathrm{AP}$ \\
\hline & 20 & Rattlesnake Mountain & 9.1 & WS, WD, T, P, RH \\
\hline & 21 & Hanford Meteorology Station & 124.3 & WS, WD, T, P, AP \\
\hline & 22 & Pasco & 9.1 & $\mathrm{WS}, \mathrm{WD}, \mathrm{T}, \mathrm{P}$ \\
\hline & 23 & Gable West & 9.1 & WS, WD, T \\
\hline & 24 & 100-F Area & 9.1 & WS, WD, T, P \\
\hline & 25 & Vernita Bridge & 9.1 & $\mathrm{WS}, \mathrm{WD}, \mathrm{T}$ \\
\hline & 26 & Benton City & 9.1 & WS, WD, T, P, ST \\
\hline & 27 & Vista & 9.1 & WS, WD, T, P \\
\hline & 28 & Roosevelt & 9.1 & WS, WD, T, AP, P \\
\hline & 29 & K-Basin & 9.1 & WS, WD, T, AP, P \\
\hline & 30 & HAMMER & 9.1 & WS, WD, T \\
\hline $\begin{array}{l}\mathrm{AP}= \\
\mathrm{DP}= \\
\mathrm{RH}= \\
\mathrm{P}= \\
\mathrm{ST}= \\
\mathrm{T}= \\
\mathrm{TD}= \\
\mathrm{WD}= \\
\mathrm{WS}=\end{array}$ & $\begin{array}{l}=\text { atmost } \\
=\text { dew-p } \\
=\text { relativ } \\
=\text { precip. } \\
=\text { subsur } \\
=\text { tempe } \\
=\text { tempe } \\
=\text { wind } \\
=\text { wind } \mathrm{s}\end{array}$ & $\begin{array}{l}\text { pressure. } \\
\text { amperature. } \\
\text { sidity. } \\
\text { oil temperature } \\
\text { difference. } \\
\text { on. }\end{array}$ & & \\
\hline
\end{tabular}




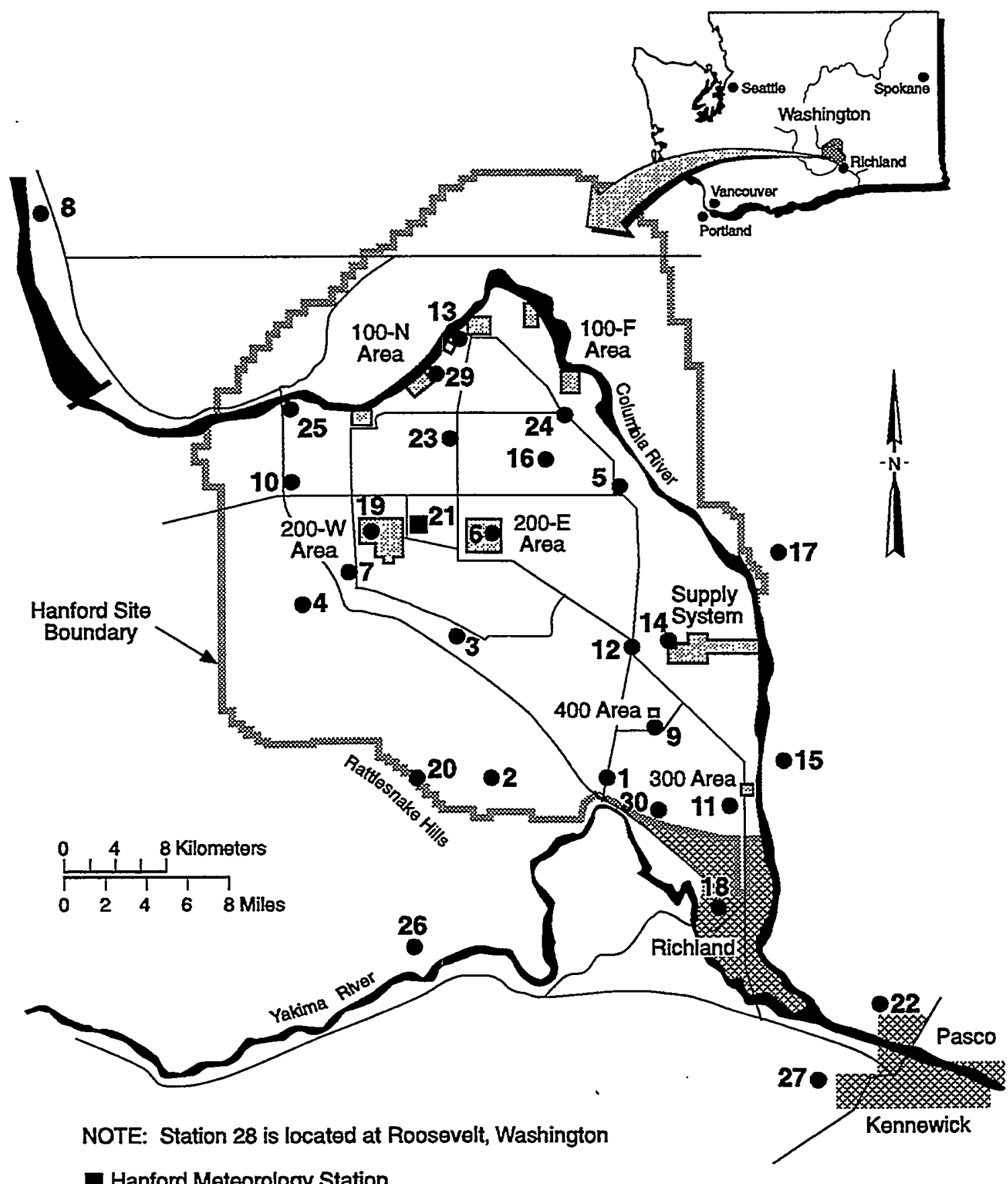

Hanford Metoorology Station

Hanford Meteorological Monitoring Network Station

sa970900821

Figure III.C-1. Meteorological Monitoring Stations on the Hanford Site and in Surrounding Areas 
Wind. Wind speed and direction are measured at the 9.1-meter level at all remote meteorological monitoring stations, at the 25- and 60-meter levels on the three 61-meter towers onsite (see Table III.C1), and at the 15.2-, 61.0-, and 121.9-meter levels on the 124.3-meter tower at the Hanford Meteorology Station.

Wind speed at most monitoring stations (except Stations 19, 20, 22, and 29) (see Figure III.C-1) is measured using sensors ( 3 cup heavy-duty aluminum anemometer) with a low starting threshold over a wide range of wind speeds. At Station 20, located on the top of Rattlesnake Mountain, where light winds are unusual and sustained wind speeds in excess of 45 meters per second are common, a sturdier anemometer (with a higher starting threshold but a greater range) is used. At Stations 19, 22, and 29, which are solar powered, a wind monitor (with a propeller, rather than a cup anemometer) is used because it is less susceptible to freezing because of moisture and fog. The wind speed sensor specifications, by station number, are indicated below:

- Stations 1 to 18,23 to 28,30

Threshold

Operating range

Accuracy

\section{- Station 19}

Threshold

Operating range

\section{- Station 20}

Threshold

Operating range

1 to 2 meters per second

0 to 90 meters per second (gust survivability to $90+$ meters per second)

0.22 meter per second

0 to 56 meters per second

0.07 meter per second or $1.0 \%$, whichever is greater

\section{- Station 22}

Threshold

Operating range

1 meter per second

0 to 60 meters per second (gust survivability to 100 meters per second)

\section{- Station 29}

Threshold 0.4 meter per second

Operating range 0 to 40 meters per second (gust survivability to 45 meters per second).

Wind direction sensors at most of the monitoring stations, except Stations 19, 20, 22, and 29 where wind monitors are used, are counterbalanced, lightweight vanes attached to a shaft coupled to a precision 
low-torque potentiometer. These sensors have low starting thresholds and fast dynamic response. The wind direction sensor specifications, by station number, are indicated below:

- Stations 1 to 18,23 to 28,30

Threshold

Operating range

Accuracy

Damping ratio

Distance constant

\section{- Station 19}

Threshold

Operating range

Accuracy

\section{- Station 20}

Threshold

Operating range

Accuracy

\section{- Station 22}

Threshold

Operating range

Accuracy

\section{- Station 29}

Threshold

Operating range

Accuracy
0.22 meter per second

0 to 360 degrees

\pm 2 degrees

0.4 at 10 degrees initial angle of attack

1.1 meters
1 meter per second

0 to 360 degrees

\pm 5 degrees

1 meter per second

0 to 360 degrees

\pm 5 degrees

The wind speed and wind direction sensors at all monitoring locations, except Stations 19, 20, 22, and 29 are heated to minimize the accumulation of rime and/or freezing precipitation during the winter.

Temperature. Air temperature is measured at 1.5 meters at all of the monitoring stations, with additional measurements at the 10 - and 60 -meter levels (for measurement of $\Delta \mathrm{T}$ for atmospheric stability designation) at the three 61-meter monitoring stations (see Table III.C-1). Temperature is measured at the 0.9-, 9.1-, 15.2-, 30.5-, 61.0-, 76.2-, 91.4-, and 121.9-meter levels on the 124.3-meter tower.

The temperature sensor (on all but the 124.3-meter tower) is an epoxy coated thermistor composite that exhibits relatively large resistance changes in response to small temperature changes. Fast-response 
sensors (with a time constant of 0.6 second) are used. All of the 9.1-meter monitoring stations have naturally aspirated radiation shields, and the three 60-meter stations have mechanically aspirated shields. The thermistor temperature sensor specifications are given below:

$\begin{array}{ll}\text { Probe accuracy } & \pm 0.15 \text { degree Celsius } \\ \text { Range } & -30.0 \text { to } 50.0 \text { degrees Celsius } \\ \text { Time constant } & 0.6 \text { second. }\end{array}$

On the 124.3-meter tower, temperatures are measured using a platinum resistance temperature device contained in a 15-centimeter-long stainless steel housing mounted in a mechanically aspirated radiation shield. The platinum resistance temperature sensor specifications are given below:

Probe accuracy

Range

Time constant \pm 0.1 degree Celsius -50.0 to 100.0 degrees Celsius 15 seconds.

Temperature Differencing. Temperature differencing is one of several methods used to determine atmospheric stability, which is one of the parameters used in transport and diffusion calculations. Atmospheric stability is a measurement of the buoyancy of a parcel of air. The buoyancy of a parcel of air depends on its density relative to the density of the environment at the same level. If a parcel is heavier than its environment, it will tend to sink (stable); if a parcel is lighter than its environment, it will tend to rise (unstable); and if the weight is the same, it will remain at the same level as its environment (neutral). Stability classes can be determined by measuring the difference between air temperatures at two levels.

The $\Delta \mathrm{T}$ calculation at the 124.3-meter tower is made using the difference between actual temperatures measured at the 61.0- and 9.1-meter levels of the tower. At the three 61-meter monitoring stations, which measure temperature difference rather than actual temperature between 10 and 60 meters, a $\Delta T$ translator contains the electronics to convert the variable resistance from the temperature thermistor elements to low-impedance signals, then takes the difference between the two signals and converts this difference into a $\Delta \mathrm{T}$. The temperature sensors used are discussed above.

Dew-Point Temperature. Dew-point temperature is measured at the 1.5 -meter level at three 61-meter towers. The dew-point sensor is housed in a mechanically aspirated temperature/dew-point shield and consists of bifilar gold electrodes wound on a lithium chloride-impregnated glass fiber wick that encloses a thermistor temperature sensor. The dew-point sensor specifications are given below:

Operating range

Relative humidity operating limits
-40 to +50 degrees Celsius

From $100 \%$ to the relative humidity at which the lithium chloride salt temperature is 2 degrees Celsius above the ambient temperature $(11 \%$ to $18 \%$ relative humidity). 
At the Hanford Meteorology Station, a hygrothermometer system is used to measure the dew-point temperature. The monitor is located 1.5 meters above the ground and uses a chilled mirror system to monitor the dew point. The specifications for the hygrothermometer are the following:

$\begin{array}{ll}\text { Operating temperature } & -50 \text { to } 70 \text { degrees Celsius } \\ \text { Relative humidity } & 5 \% \text { to } 100 \% \\ \text { Ambient temperature } & \pm 0.6 \text { degree Celsius from }-50 \text { to } 50 \text { degrees Celsius accuracy } \\ \text { Dew-point accuracy } & \pm 0.6 \text { degree Celsius when less than } 0 \text { degree Celsius. }\end{array}$

Relative Humidity. Relative humidity at Station 20 (Rattlesnake Mountain) is measured at the 1.5-meter level of the 9.1-meter tower. The Humicap $ß$ relative humidity sensor is housed in a mechanically aspirated radiation shield. The relative humidity is measured by a thin polymer film that either absorbs or exudes water vapor as the relative humidity of the ambient air rises or drops. The dielectric properties of the polymer film depend on the amount of water contained in it - as the relative humidity changes, the dielectric properties of the film change and, therefore, the capacitance of the sensor changes. The electronics of the instrument measure the capacitance of the sensor and convert it into a relative humidity reading.

Operating range

Accuracy at 20 degrees Celsius

Time constant
-40 to 60 degrees Celsius

$\pm 2 \%$ relative humidity (from 0 to $90 \%$ relative humidity) $\pm 3 \%$ relative humidity (from 90 to $100 \%$ relative humidity) 15 seconds

Precipitation. Precipitation measurements, using recording rain gauges, are made at 22 of the 30 monitoring stations. Each rain gauge has an opening 20 centimeters in diameter to collect precipitation. Two compartments alternately fill with precipitation and tip (emptying the compartment), causing momentary closure of a mercury switch. The funnels are electrically heated for measuring the water equivalent of frozen precipitation. The heater is thermostatically controlled to be activated when the ambient temperature drops to 4 degrees Celsius. These gauges are sensitive to 0.25 millimeter and are accurate to $0.5 \%$ for a rainfall rate of 12.70 millimeters per hour. The average precipitation event at the Hanford Meteorology Station is only 2.3 millimeters.

Atmospheric Pressure. Atmospheric pressure is measured at the 1.5-meter level at the 10 sites indicated in Table III.C-1. The sensors are located within the signal interface unit enclosures. The pressure sensor specifications are given below:

Scaling range $\quad 800$ to 1,100 millibars

Nonlinearity $\quad \pm 0.05 \%$ of full scale

Full-scale accuracy $\quad \pm 0.1 \%$ of full scale or \pm 0.3 millibar.

\section{Instrument Calibration and Maintenance}

All measurement and test equipment is calibrated on an annual basis, and the calibrations are spread throughout the year. The maintenance services calibration recall system is used to notify the project manager when instrument calibration is due. However, because data are reviewed hourly by the fore- 
caster on duty, any apparent problems with data from a particular station are immediately noted and the instrument specialists are advised. Instruments are recalibrated after any repair before being returned to use. Because of the large number of monitoring locations and the distances involved, it is not practical to perform total system calibration on a more frequent basis. Again, because of the large number of monitoring locations that contribute data to the meteorological monitoring system, the temporary loss of data from one or two locations is not critical to the operation of the system as a whole. Even so, every attempt is made to keep the amount of downtime to a minimum.

In accordance with quality assurance requirements, PNNL maintains the procedures to calibrate all measurement and test equipment used by the Meteorological and Climatological Services Project. Primary, secondary, and traveling calibration standards are traceable through the Hanford Standards Laboratory to the National Institute of Standards and Technology. The procedures state that 2 months before the expiration of calibration on any piece of equipment or instrument, a notice of instrument calibrations is generated that specifies the instrumentation scheduled for calibration. The notice is reviewed and signed by the instrument custodian (in this case the Meteorological and Climatological Services Project manager), authorizing the calibration of the equipment specified. On completion of calibration, a record of calibration is generated, and copies of the record are provided to the applicable instrument laboratory, the instrument custodian, and the PNNL Engineering, Design and Craft Resources Department.

\section{Data Acquisition}

Data are acquired and processed at each monitoring station using a signal interface unit and a telemetry unit. Most of the signal interface and telemetry units are powered commercially; however, units at six sites $(7,19,22,25,28$, and 29$)$ are powered by batteries charged by solar panels. The signal interface unit acquires and processes the signals from the individual instruments, and the telemetry unit transmits the processed data to the Hanford Meteorology Station via a radio repeater on Rattlesnake Mountain. Inputs to the signal interface unit may be analog, counter, or digital. The unit scans its channels for information every 5 seconds (or every second for the tipping bucket rain gauge), stores the information for 15 minutes, and sends the 15-minute-averaged values (made up of 180 samples) to the Hanford Meteorology Station. Values are transmitted on the hour and at 15-minute intervals. The output is a digital sequence of numbers transmitted at 416.5 megahertz with 4 watts of power.

The data transmitted from the remote monitoring stations are received at a base station located at the Hanford Meteorology Station and are sent to a personal computer network via an RS-232 serial data link.

\section{Atmospheric Transport and Diffusion}

The Air Pollutant Graphical Environmental Modeling System (APGEMS) is an atmospheric dispersion model that predicts ground-level concentrations and deposition fields of air contaminants released from point sources given contaminant release rates, source configurations and meteorological observations of winds, mixing heights, precipitation rates and atmospheric stability. APGEMS is embedded in a Windows-based graphical user interface that allows the user to easily specify input information and view 
the output concentration, dose and deposition fields on maps of the area of interest. The implementation of APGEMS for the Hanford Site uses meteorological data from the Hanford Meteorological Monitoring Network and radionuclide source information.

APGEMS is applicable at source-to-receptor transport distances of a few hundred meters to a few hundred kilometers. The model operates at two "nested" grid resolutions; a fine grid to resolve the dispersion within a few kilometers of the release, and a course grid to track plume transport to approximately 200 kilometers from the source (assuming the source at the center of the grid). The model uses a three-dimensional diagnostic wind model to specify the time and space varying winds over the modeling domain. A special feature of the wind model is that during stable atmospheric conditions it accounts for flow channeling and blocking from major terrain features, in addition to treating drainage flows.

\section{Quality Assurance}

Quality assurance for the Meteorological and Climatological Services Project is established and implemented by PNNL's formal quality assurance program, as contained in PNNL's Standards-Based Management System (PNNL 2000). The quality assurance program conforms to the requirements of DOE Order 414.1A.

Independent surveillances and audits of the Meteorological and Climatological Services Project activities and procedures to ensure compliance with PNNL's Quality Management System and the project quality assurance plan are conducted by the PNNL Process Quality Department. These surveillances and audits can be initiated by a DOE monitor, the PNNL program manager, the project manager, or the project quality engineer on either a routine and/or a random basis.

\section{Data Management}

Meteorological data from the monitoring network are collected, processed, and archived on a dedicated network of personal computers at the Hanford Meteorology Station. Incoming data are written to several independent hard drives on separate personal computers simultaneously, so that data are available even in the event of the failure of an individual hard drive or personal computer. MetViewer software is used for data management and display.

The 15-minute-averaged data from the monitoring network are used as input to atmospheric transport and diffusion models for emergency response and are maintained for 10 days on the mainframe computer. At the beginning of the eleventh day, the first day of the 15-minute data is purged and 15-minute data from the newly designated tenth day are stored. These data are available on a network server that can be accessed by emergency preparedness organizations for their needs.

For permanent storage, the 15-minute data are converted into hourly data. These data are processed daily using the ARCHIVE computer code (PNL-6279, Vol. 10). This computer program converts hourly binary meteorological data from the 9.1-, 61- and 124.3-meter towers into formatted (ASCII) data and organizes the converted data into appropriate monthly files. 
At the beginning of every month, the monthly data on the personal computer network are processed prior to permanent storage. All data are reviewed using quality assurance computer programs (PNL-6279, Vol. 9). These programs check all data for the following types of potential errors:

- parameters out of range (e.g., January temperature less than 16.7 degrees Celsius)

- unreasonable changes in parameter magnitude from one hour to the next (e.g., temperature change less than 5.6 degrees Celsius)

- parameter conflict (e.g., visibility below a specific threshold value with no obstructing phenomena indicated [fog, snow, etc]).

These programs generate error listings that allow for the resolution of possible data irregularities. These computer-generated error listings are maintained on file; however, errors that can be readily resolved are corrected and archived. If they cannot be corrected, the data are indicated as missing.

On completion of these monthly quality assurance checks, the final data are archived on multiple hard disks, and are available for additional processing (e.g., joint frequency distributions, wind roses, data summaries), as necessary.

\section{Exceptions}

No exceptions have been taken to "should" statements in DOE/EH-0173T.

\section{References}

DOE/EH-0173T. 1991. Environmental Regulatory Guide for Radiological Effluent Monitoring and Environmental Surveillance. Assistant Secretary for Environment, Safety and Health, U.S. Department of Energy, Washington, D.C.

DOE Order 414.1A. "Quality Assurance."

DOE Order 5400.1. "General Environmental Protection Program."

PNL-6279. 1989. Hanford Meteorological Station Computer Codes, Volume 9 - The Quality Assurance Computer Codes. K. W. Burk and G. L. Andrews, Pacific Northwest Laboratory, Richland, Washington.

PNL-6279. 1989. Hanford Meteorological Station Computer Codes, Volume 10 - The ARCHIVE

Computer Code. G. L. Andrews and K. W. Burk, Pacific Northwest Laboratory, Richland, Washington.

PNL-6509. 1988. The Hanford Meteorological Data Collection System and Data Base. G. L. Andrews, Pacific Northwest Laboratory, Richland, Washington.

PNL-6684. 1988. The Data Collection Component of the Hanford Meteorology Monitoring Program. C. S. Glantz and M. M. Islam, Pacific Northwest Laboratory, Richland, Washington. 
PNNL. 2000. In Standards-Based Management System (accessed online on November 1, 2000). Available URL: http://sbms/ch00d010.htm

PNNL-13117. 2000. Hanford Site Climatological Data Summary 1999, With Historical Data. D. J. Hoitink, K. W. Burk, and J. V. Ramsdell. Pacific Northwest National Laboratory, Richland, Washington.

PNNL-13230. 2000. Hanford Site Environmental Report for Calendar Year 1999. T. M. Poston, R. W. Hanf, and R. L. Dirkes (eds.), Pacific Northwest National Laboratory, Richland, Washington. 


\section{Distribution}

No. of

Copies

\section{OFFSITE}

K. Campbell

Fish and Wildlife Service

U.S. Department of the Interior

P.O. Box 1157

Moses Lake, WA 98837

Confederated Tribes of the Umatilla Indian

Reservation

P.O. Box 638

Pendleton, OR 97801

R. A. Danielson

Washington State Department of Health

5508 Englewood Avenue

Yakima, WA 98908

R. Jim, Manager

Confederated Tribes and Bands of the

Yakama Indian Nation

Environmental Restoration/Waste

Management Program

2802 Main Street

Union Gap, WA 98903

Nez Perce Tribe

P.O. Box 365

Lapwai, ID 83540-0365

Oregon Department of Environmental

Quality

811 SW Sixth Avenue

Portland, OR 97203

J. W. Schmidt

Washington State Department of Health

3011 W. Hood Avenue

Kennewick, WA 99336
No. of

Copies

J. Stohr

Washington State Department of Ecology

P.O.Box 47600

Olympia, WA 98504-7600

A. Wallo III

Air, Water, and Radiation Division

Office of Environment

U.S. Department of Energy

1000 Independence Ave. S.W.

Washington, DC 20585

6 Washington State Department of Health

Division of Radiation Protection

P.O. Box 47827

Olympia, WA 98504-7827

Attn: A. W. Conklin (4)

D. McBaugh (2)

ONSITE (124)

E. J. Antonio

K3-54

B. P. Atencio

P7-68

M. Y. Ballinger

BSRC

J. A. Bates

G1-30

G. M. Bell

A5-52

R. L. Biggerstaff

$\mathrm{H} 0-02$

L. E. Bisping

K6-75

W. J. Bjorklund

$\mathrm{K} 3-75$

R. J. Boom

T6-14

E. M. Bowers

A2-15

H. C. Boynton

T4-52

J.E. Bramson

T5-54

S. L. Brey

T6-04

C. R. Briggs

A1-61

R. W. Bryce

K6-75

S. E. Clarke

A6-38

E. T. Coenenburg

H9-03

S. F. Conley

K6-75

G. M. Crummel

R1-51 
DOE/RL $91-50$

Rev. 3

No. of

Copies

$\begin{array}{lr}12 & \text { P7-68 } \\ \text { E. G. Damberg } & \mathrm{G} 1-27 \\ \text { L. P. Diediker } & \mathrm{S} 5-03 \\ \text { T. A. Dillhoff } & \mathrm{K} 6-75 \\ \text { R. L. Dirkes } & \mathrm{G} 3-26 \\ \text { B. J. Dixon } & \mathrm{H} 1-11 \\ \text { J. J. Dorian } & \mathrm{K} 6-96 \\ \text { P. E. Dresel } & \mathrm{P} 7-68 \\ \text { D. L. Edwards } & \mathrm{R} 1-51 \\ \text { B. G. Erlandson } & \mathrm{H} 0-02 \\ \text { K. R. Fecht } & \mathrm{S} 6-71 \\ \text { D. L. Flyckt } & \mathrm{H} 0-19 \\ \text { B. H. Ford } & \mathrm{G} 1-37 \\ \text { T. P. Frazier } & \mathrm{K} 6-96 \\ \text { J. S. Fruchter } & \mathrm{K} 6-75 \\ \text { R. W. Fulton } & \mathrm{A} 5-13 \\ \text { M. J. Furman } & \mathrm{B} 5-01 \\ \text { L. E. Gadbois } & \mathrm{H} 0-23 \\ \text { K. A. Gano } & \mathrm{K} 6-96 \\ \text { B. M. Gillespie } & \mathrm{A} 2-15 \\ \text { W. M. Glines } & \mathrm{G} 1-29 \\ \text { E. M. Greager } & \mathrm{T} 5-57 \\ \text { K. A. Hadley } & \mathrm{A} 2-15 \\ \text { J. B. Hall } & \mathrm{K} 6-75 \\ \text { R. W. Hanf } & \mathrm{K} 6-96 \\ \text { M. J. Hartman } & \mathrm{R} 1-43 \\ \text { D. R. Herman } & \mathrm{A} 5-13 \\ \text { R. D. Hildebrand } & \mathrm{K} 9-30 \\ \text { D. J. Hoitink } & \mathrm{H} 5-26 \\ \text { A. R. Johnson } & \mathrm{K} 6-96 \\ \text { V. G. Johnson } & \mathrm{H} 0-02 \\ \text { R. J. Landon } & \mathrm{S} 4-49 \\ \text { G. J. LeBaron } & \mathrm{R} 1-51 \\ \text { J. J. Luke } & \mathrm{K} 6-96 \\ \text { S. P. Luttrell } & \mathrm{N} 1-23 \\ \text { C. E. Marple } & \mathrm{H} 1-11 \\ \text { S. M. McKinney } & \mathrm{R} 1-51 \\ \text { P. C. Miller } & \mathrm{X} 4-03 \\ \text { D. L. Mitchell } & \mathrm{K} 6-86 \\ \text { L. F. Morasch } & \\ \text { B. E. Opitz } & \end{array}$

No. of

Copies

G. W. Patton

K6-75

C. J. Perkins H1-11

J. K. Perry L1-04

K. A. Peterson G1-37

R. E. Peterson K6-96

T. M. Poston K6-75

P. A. Powell R1-51

D. E. Rasmussen L1-04

J. E. Rasmussen H6-60

D. L. Renberger H6-10

K Rhoads K3-54

J. R. Robertson L0-33

H. M. Rodriguez A5-15

D. J. Rokkan G1-27

D. R. Sherwood B5-01

K. D. Shields P7-68

F. M. Simmons $\quad$ S6-81

R. M. Smith K6-96

R. W. Szelmeczka S6-72

K. M. Thompson A5-13

B. L. Tiller K6-85

A. C. Tortoso H0-12

D. B. Van Leuven X3-71

D. D. Volkman B1-13

D. C. Ward A2-15

D. J. Watson X3-79

B. A. Williams K6-81

J. A. Winterhalder A1-14

S. H. Wisness A2-15

C. D. Wollam G6-73

R. K. Woodruff P7-68

J. H. Zeisloft A2-15

J. P. Zoric X5-53

DOE Public Reading Room H2-53

2 Environmental Restoration

Program Information Center $\quad$ H6-08

7 Information Release Office K1-06

Lockheed Martin Hanford

Corporation Central Files B1-07 